\title{
A RECLAMAÇÃO COMO INSTRUMENTO DE CONTROLE DA APLICAÇÃO DE PRECEDENTES DO STF E DO STJ: ANÁLISE FUNCIONAL, ESTRUTURAL E CRÍTICA
}

\author{
DISSERTAÇÃO DE MESTRADO
}

ORIENTADOR: PROF. DR. HEITOR VITOR MENDONÇA SICA

UNIVERSIDADE DE SÃO PAULO

FACULDADE DE DIREITO

São Paulo-SP

2015 


\title{
A RECLAMAÇÃO COMO INSTRUMENTO DE CONTROLE DA APLICAÇÃO DE PRECEDENTES DOSTF E DO STJ: ANÁLISE FUNCIONAL, ESTRUTURAL E CRÍTICA
}

\begin{abstract}
Dissertação de Mestrado apresentada à Banca Examinadora do Programa de Pós-Graduação em Direito, da Faculdade de Direito da Universidade de São Paulo, como exigência parcial para obtenção do título de Mestre em Direito, na área de concentração Direito Processual Civil, sob a orientação do Prof. Dr. Heitor Vitor Mendonça Sica.
\end{abstract}

UNIVERSIDADE DE SÃO PAULO

FACULDADE DE DIREITO

São Paulo-SP

2015 


\section{AGRADECIMENTOS}

Este trabalho não se realizaria não fosse a confiança que nele foi depositada pelo Professor Heitor Sica desde a primeira entrevista do processo seletivo. Confiança esta que se renovou em todas as fases até a sua conclusão e que me incentivou a vencer as dificuldades extras que se colocaram no caminho.

Mestre não é quem conhece, mas quem compartilha seu conhecimento com humildade, generosidade e disposição. O Professor Heitor é assim; por isso, em seu nome, cumprimento e agradeço todos os mestres que tive na vida e que me ajudaram a chegar até aqui.

Durante todo o processo de construção desta dissertação, contei com o imensurável apoio dos meus colegas de trabalho.

Aos meus queridos amigos da Gerência Jurídica da Companhia do Metropolitano de São Paulo, a quem agradeço nas pessoas dos advogados Simone Zanetti, Eduardo Iguti, Evandro Rocha, Carlos Alberto Cancian e Carlos Renato Lonel Alva Santos.

Agradeço, também, a todos meus sócios e amigos da Duarte Garcia, Caselli Guimarães e Terra Advogados, em especial aos meus companheiros do Departamento de Direito Administrativo, que me acolheram com tanto carinho e que tanta compreensão tiveram com minha ausência.

Por fim, o agradecimento mais especial: à minha família.

Aos meus pais, Lenita e Roque, que me transmitiram o melhor de si e dos nossos antepassados, sem o que eu não seria.

Ao meu irmão, Eduardo, melhor amigo e companheiro de todas as horas, que sempre incentiva tudo que faço à beira da irresponsabilidade.

À Mirella, ao Joaquim e ao pequenino Miguel, prometo compensar cada segundo de ausência em que não tiveram o marido e o pai que tanto merecem. Sem a força do olhar e do sorriso de vocês, eu não conseguiria. 
"As leis da educação são as primeiras que recebemos. E, como nos preparam para sermos cidadãos, cada família particular deve ser governada no mesmo plano da grande família que compreende todas. Se o povo em geral tem um princípio, as partes que o compõem, isto é, as famílias, também o terão. As leis da educação serão, portanto, diferentes em cada espécie de governo." 


\section{SUMÁRIO}

\section{Introdução...7}

\section{Reclamação no STF e no STJ...10}

1.1. Origem e evolução...10

1.1.1. Primeiro precedente histórico: correição parcial...10

1.1.2. A reclamação constitucional...16

1.1.2.1.A formulação do instituto...17

1.1.2.2.A inclusão no Regimento Interno do STF...20

1.1.2.3.Constituição Federal de 1967: consolidação da hipótese regimental...21

$$
\begin{gathered}
\text { 1.1.2.4.Constituição } \quad \text { Federal de } 1988: \\
\text { constitucionalização...27 }
\end{gathered}
$$

1.1.3. Direito infraconstitucional...32

1.1.4. Reclamação no novo Código de Processo Civil...38

1.2. Natureza jurídica...43

1.3. Reclamação e recurso: concorrência de meios de impugnação...53

2. Precedente judicial no Direito Brasileiro...59

2.1.Decisão judicial como fonte do Direito...59

2.2. Noção de precedente...63

2.3. Eficácia das decisões do STF e do STJ...72

2.4.Precedentes obrigatórios: o efeito vinculante...83

3. Reclamação no controle da aplicação de precedentes do STF e do STJ...89

3.1. Reclamação no controle de constitucionalidade...91

3.2. Reclamação para controlar a aplicação de súmula vinculante...103

3.2.1. A limitação probatória...108 
3.3.Reclamação perante o STJ no microssistema dos Juizados Especiais...121

3.4. Reclamação no novo Código de Processo Civil: novas hipóteses?...140

4. Análise crítica: (re)atomização dos litígios...143

5. Conclusões...160

Bibliografia...163 


\section{INTRODUÇÃO}

O presente trabalho fará uma análise crítica do instituto da reclamação previsto nos artigos 102, I, $l, 103-\mathrm{A}, \S 3 .^{\circ}$, e $105, \mathrm{I}, f$, da Constituição Federal do ponto de vista de sua função de controle da aplicação dos precedentes do Supremo Tribunal Federal e do Superior Tribunal de Justiça.

O estudo se estrutura em quatro capítulos; no primeiro, volta-se à análise da reclamação constitucional, instituto genuinamente brasileiro, que nasceu no berço da jurisprudência do Supremo Tribunal Federal, embora deite raízes em instrumento homônimo de natureza marcadamente correicional e administrativo-hierárquica, também chamado de "correição parcial". Demonstraremos que a dificuldade da doutrina em acomodar o instituto em um ou outro escaninho classificatório predeterminado esteja, talvez, no fato de ainda não ter atentado para as várias finalidades para as quais a reclamação já foi e vem sendo utilizada, bem como para a realidade de que, já na origem, possuía a finalidade precípua de colocar o processo nos trilhos, cassando a decisão impugnada ou corrigindo omissões indevidas. Diante desse quadro, delimitaremos o objeto do estudo como sendo as reclamações cujo objeto seja o controle da eficácia vinculante das decisões daqueles tribunais superiores.

O segundo capítulo busca delimitar o conceito de precedente judicial com o qual se desenhará o presente trabalho. Após traçarmos a história do precedente judicial no Direito brasileiro, desde os assentos da Casa de Suplicação de Portugal até os verbetes vinculantes do Supremo Tribunal Federal, para demonstrar que, em um sistema jurídico marcado pela origem do civil law, só faz sentido falar em precedente quando as decisões judiciais são dotadas de eficácia vinculante. A chamada eficácia persuasiva não é suficiente para tornar uma decisão judicial um precedente. A marca da vinculação, portanto, é o que diferencia uma decisão e a torna capaz de ser parâmetro para a reclamação de que o presente trabalho cuida.

O terceiro capítulo é reservado à análise das hipóteses em que a reclamação constitucional é destinada a controlar a aplicação de precedentes do Superior Tribunal de Justiça e do Supremo Tribunal Federal. Aqui, portanto, serão analisados os casos em que o instrumento se volta a garantir a autoridade das decisões desses tribunais, quando serão 
vistos casos concretos de utilização da reclamação levando em conta as espécies de precedentes vinculantes analisadas no capítulo anterior.

Analisa-se, nesse capítulo, como os tribunais superiores vêm engendrando a reclamação constitucional como meio adequado de controle da eficácia vinculante de seus precedentes, escorando-se na hipótese constitucional que admite o uso do instrumento para garantir a autoridade das decisões. Assim, por exemplo, trataremos do caso de uso da reclamação para controle de aplicação de acórdãos proferidos em sede de controle concentrado de constitucionalidade, de decisões tomadas no sistema de recursos repetitivos e as súmulas vinculantes.

Vê-se, outrossim, que a recente ampliação de cabimento da reclamação, derivada da ampliação das hipóteses de decisões dotadas de eficácia vinculante,tem preocupado aqueles tribunais superiores. $\mathrm{E}$ isso se deve, principalmente, à possibilidade de encurtamento de caminho que o uso desse instrumento processual permite, o que abre as portas do STF e do STJ para uma gama imensa de supostos legitimados, que veem o caminho livre para suas pretensões, sem os mesmos obstáculos comumente antepostos aos recursos especial e extraordinário.

Nesse capítulo, ainda, faremos alguns apontamentos sobre como a reclamação vem disciplinada na última versão do projeto de novo Código de Processo Civil.

O quarto capítulo se ocupa de questões polêmicas, que levam à reflexão sobre a viabilidade de depositar, na reclamação constitucional, toda a esperança de ver, no Brasil, um sistema eficiente de respeito aos precedentes judiciais, que alcance a tão almejada tutela jurisdicional tempestiva, segura, eficiente e justa. Analisaremos, também, os pressupostos de admissibilidade da reclamação; veremos a polêmica hipótese de cabimento de reclamação perante o STJ, para controlar o respeito a suas decisões em sede de Juizados Especiais. As implicações do uso concomitante de vários meios de controle de precedentes, como o recurso e a reclamação, também será objeto de estudo desse quarto capítulo.

Veremos, ao fim, que a caminhada rumo à chamada molecularização dos conflitos está intimamente ligada à necessidade de respeito aos precedentes, pois leva a uma igualdade maior no julgamento das causas semelhantes ou idênticas e à formulação de soluções que, por mais genéricas e amplas, passam a surtir efeitos para além da relação processual coletiva onde nasceram. 
Todavia, de outro lado, de nada adiantará o sistema prever mecanismos de seleção de processos representativos por parte dos tribunais e estimular os processos coletivos, para, depois, permitir que toda aquela massa de jurisdicionados que foi representada possa aportar diretamente a esses tribunais. A busca pela isonomia nas decisões, calcada na previsibilidade e na segurança jurídicas, é o mote maior da instituição de um sistema de precedentes vinculantes, mas o controle dessa aplicação não pode acabar por "reatomizar" os conflitos que foram molecularizados, sob pena de sobrecarregarmos ainda mais os tribunais superiores, que se afastarão de suas primordiais funções.

O objeto do trabalho, em síntese, põe em questão a própria viabilidade de impor a eficácia de precedentes por meio de instrumento processual específico, diante da constatação de quede tais decisões se extrai norma geral e abstrata, apesar de serem produto de um primeiro contato entre o mundo dos fatos e o mundo da norma jurídica; trata-se de uma norma mais concretizada, mas que não perde o caráter generalizante. Assim é que o seu respeito e a sua aplicação, antes de serem impostos pela lei, como vem sendo feito no Brasil, deveriam se construir paulatinamente no sistema jurídico, a partir da ampliação da legitimidade desses precedentes e de sua capacidade de persuasão.

Essa legitimidade, para se tornar vinculante, está ligada a alguns fatores, que deverão ser observados, como o respeito irrestrito ao contraditório e à fundamentação adequados na fase de construção do precedente, e o obrigatório respeito por parte dos tribunais dos quais promanam. Se os próprios agentes prolatores dos precedentes judiciais não os respeitarem, como exigir que os demais órgãos, seja do Poder Judiciário seja das outras duas esferas de poder da República, os respeitem?

A estrutura hierarquizada do Poder Judiciário, somada a um individualismo arcaico e a uma falta de visão de unicidade e organicidade do Direito, leva a uma natural tendência de desrespeito ou desqualificação das decisões dos tribunais superiores. Enquanto não se mudar o foco e a forma de ver o exercício da jurisdição, seu produto final não será visto como elemento essencial na formação do Direito do País, fator relevantíssimo de evolução cultural e fortalecimento das instituições democráticas. 


\section{CAPÍTULO 1 - RECLAMAÇÃO NO STF E NO STJ}

\subsection{Origem e evolução}

Embora o título do capítulo já se refira à reclamação constitucional, é preciso lembrar que esse adjetivo somente lhe pode ser acrescentado a partir da promulgação da Constituição Federal de 1988. Antes disso, embora utilizada pelo Supremo Tribunal Federal, era simplesmente reclamação - valendo lembrar que o Superior Tribunal de Justiça nasceu com a Carta de 1988. E, para chegarmos ao estágio atual de desenvolvimento do instituto, será preciso regredir para meados do século passado, quando se encontram os primeiros acórdãos de reclamações julgadas pelo STF.

Mais atrás ainda, a origem desse instituto, incluindo o próprio nomen iuris, remonta a procedimentos de natureza correicional que existiam nas Justiças dos Estados, voltados a disciplinar a condução do processo pelo magistrado ou pelos funcionários que estivessem a tumultuar o normal andamento do feito, sempre que não houvesse recurso com efeito suspensivo contra o ato do juiz (comissivo ou omissivo). De partida, então, interessa-nos traçar a linha do tempo desses procedimentos, cujo nome variava entre correição parcial, reclamação e representação, daí a doutrina referir-se a "reclamação correicional".

Na sequência, mostraremos toda a evolução do instituto, com os debates sobre a sua natureza jurídica, até chegarmos à fase atual, na qual a reclamação constitucional se divorciou de vez de suas homônimas regimentais, tanto pelas hipóteses de cabimento como pela natureza jurídica reconhecida pela Jurisprudência do Supremo.

\subsubsection{Primeiro precedente histórico: correição parcial}

Como se verá, parece inegável a ligação existente entre a atual reclamação prevista na Constituição Federal de 1988 e a correição parcial, enquanto mecanismo idealizado para fazer valer as decisões judiciais, preservar competência de órgãos hierarquicamente superiores e manter, assim, a ordem legal do processo. 
EGAS DiRCEU Moniz DE ARAGÃo foi pioneiro no trato da correição parcial, em obra que se tornou referência ${ }^{1}$.Sobre as origens do instituto, o autor afirma que a correição parcial deriva, remotamente, da supplicatio romana $^{2}$ e da sopricação portuguesa ${ }^{3}$, bem como do agravo de ordenação não guardada ${ }^{4}$ e do agravo por dano irreparável ${ }^{5}$.

Isso significa dizer que as raízes da correição parcial são recursais, pois seus antepassados históricos visavam à reforma de decisões judiciais violadoras da regularidade formal do processo, ou seja, da correção de errores in procedendo. Foi exatamente essa preocupação com as regras formais que "levou os juristas portugueses a inserirem nas Ordenações do Reino a possibilidade de as partes recorrerem aos tribunais superiores contra as infrações de natureza formal cometidas pelos juízes" ${ }^{\text {. }}$.

Com a autorização dada pela Constituição de 1891 para que os Estados editassem seus próprios códigos de processo, ocorreu que a maioria desses códigos estaduais, com pequenas variações, acolheu a hipótese de agravo para correção de vícios formais decorrentes da atuação judicial. A propósito, MonIZ DE ARAGão realça que:

"através desses casos de agravo alcançava-se amplitude incomensurável no recorrer, nem apenas quando houvesse infração manifesta de regra procedimental, como dizia a lei gaúcha, mas em toda e qualquer hipótese de ilegalidade, consoante a norma pernambucana, ou, mesmo, sempre que o 'efeito prejudicial do despacho interlocutório não pudesse ser

\footnotetext{
${ }^{1}$ A correição parcial. São Paulo: José Bushatsky, 1969.

2 "Surgida no período dacognitio extra ordinem, asupplicatiofigurava, portanto, ao lado da apelação, como sendo o outro recurso de que os litigantes romanos podiam lançar mão para o reexame das questões decididas em instância inferior"(ob. cit., p. 10 e 15).

3،[...] para pôr fim aos abusos dos senhores que não poucas vezes impediam o recurso de alcançar os juízes superiores, determina que a apelação fosse encaminhada diretamente a 'El Rey"' (TUCCI, José Rogério Cruz e; AzEvedo, Luiz Carlos de. Lições de história do processo civil lusitano, p. 237). Nas Ordenações Manuelinas, a sopricação passa a ser chamada de "agravo ordinário" (idem, ibidem, p. 240).

${ }^{4}$ Agravo este, previsto nas Ordenações Filipinas, em 3.20.46: "e de nenhum mandado, nem interlocutória, que qualquer juiz ponha ou mande judicialmente acerca do ordenar e processar o feito se poderá apelar, nem agravar, salvo nos casos declarados nesta ordenação, ou quando se agravar de ordenação não guardada acerca do ordenar o processo: porque então se poderá agravar por petição, ou por instrumento". Para TUCCI\&AZEVEDO, não se tratava de uma modalidade específica de recurso, pois havia apenas quatro modalidades de agravo: ordinário, de petição, de instrumento e no auto do processo. Na verdade, entendimento diverso derivava da confusão que se fazia entre o conteúdo e a forma do recurso, pois, no caso, o seu conteúdo é que vinha definido nas Ordenações e dizia respeito às hipóteses de error in procedendo, podendo ser interposto por petição ou por instrumento, de acordo com o critério geográfico das 5 léguas (ob. cit., p. 135).

${ }^{5}$ Previsto no artigo 669, $\S 15$, do Regulamento 737, de 1950, tinha seu cabimento pautado pela existência de um dano irreparável às partes, causado pelos juízes através de despachos interlocutórios (MONIZ DE ARAGÃo, ob. cit., p. 13).

${ }^{6}$ MONIZ DE ARAGÃo, ob. cit., p. 11-12.
} 
emendado sem grande dificuldade ou dispêndio', como se lia no Projeto de Código de Processo Civil e Comercial do Estado de São Paulo"7.

Todavia, o Código de 1939 deixou de importar as hipóteses previstas nas leis estaduais para o agravo que visasse a atacar decisão violadora da regularidade dos atos do processo, bem como reduziu ao mínimo os casos de agravo de instrumento, o que forçou o aparecimento da correição parcial, como único modo de salvaguardar as partes dos danos irreparáveis que essas decisões poderiam causar.

Assim, como sói acontecer em culturas jurídicas nas quais se confunde devido processo legal com recorribilidade infinita, sendo impossível não haver mecanismo capaz de atacar imediatamente os atos judiciais que violem a ordem legal do processo (vícios formais), no momento em que tais remédios processuais foram banidos pelo legislador, a prática passou a aceitar a correição parcial ou reclamação (esta também chamada de reclamação correicional), como forma de atacar decisões ou omissões que tumultuassem a ordem normal do feito ${ }^{8}$. Daí porque se afirma não haver razão para o uso desse instrumento quando o sistema recursal volta a ser abrangente de todo e qualquer caso de vício no processo 9 .

Durante esse período original, muito se discutiu sobre a constitucionalidade das correições previstas nas leis estaduais, em grande medida porque, por serem capazes de alterar a decisão atacada, tratar-se-ia de recurso não previsto em lei federal, esta competente para tratar da matéria (art. 5. ${ }^{\circ}$ XIX, da CF/1934). No debate, sustentava-se que, enquanto não fosse instituído um Código de Processo Civil pelo legislador federal, as

\footnotetext{
${ }^{7}$ Ob. cit., p. 14 .

${ }^{8}$ Interessante indagar o porquê de não se ter cogitado do uso do mandado de segurança nesses casos. A hipótese mais viável deve ser a que considera que o mandamus ainda era um instrumento relativamente novo e que, segundo CELSO AGRíCOLA BARBI, as primeiras investidas dos advogados de se valerem do "remédio heroico" contra ato judicial se deu apenas depois de a Constituição de 1934 prever seu cabimento contra ato “de qualquer autoridade". Depois disso, a Lei 191/36, ao disciplinar os casos de não cabimento, nada referiu sobre atos judiciais. Em suma, tratava-se de uma novidade à época, só cogitada em hipóteses de rara excepcionalidade - como o caso da penhora de rendas do Estado de Minas Gerais, em que o STF concedeu a ordem, por maioria, tendo em vista a relevância e a gravidade do caso (MS 319/MG, Rel. MIN. BENTO DE FARIA, vencido, j. 02/10/1936). Além disso, a Lei 1.533/1951 foi expressa ao limitar o cabimento do writ apenas aos casos em que não houvesse recurso nem coubesse reclamação (Do mandado de segurança, p. 131 e ss.).

9“'O campo de emprego dessas medidas estranhas [mandado de segurança e correição parcial] aos quadros recursais e ao andamento normal do feito, deveria acabar por se cingir aos casos em que cabe agravo e que este ou não tem, ou se o pode ter, não o concedeu o juiz, efeito suspensivo" (ARRUDA ALVIM PINTO, ob. cit., p. 58).
} 
leis estaduais permaneciam válidas; validade esta que deixou de existir com o Decreto-lei $1.608 / 1939$, instituindo o novo diploma processual civil brasileiro ${ }^{10}$.

Depois disso, apenas em 1951 o instituto veio a ser mencionado no corpo de uma lei. Trata-se da Lei Federal 1.533, que regulava o processo do mandado de segurança e previa, no artigo $5^{\circ}$, II, que não caberia conceder a ordem contra despacho ou decisão judicial, quando houvesse "recurso previsto nas leis processuais" ou pudesse "ser modificado por via de correção".

Veja-se que o dispositivo legal referia-se a correção ${ }^{11}$, mas admitia - ainda que implicitamente - que o "despacho ou decisão judicial" pudessem ser modificados por essa via, o que levou a maioria da doutrina e o próprio Supremo Tribunal Federal a aceitaremna, retirando dela qualquer pecha de inconstitucionalidade. Para essa corrente doutrinária e jurisprudencial, a previsão na lei encerrara a questão ao legitimar a possibilidade de, em sede de "correição parcial", substituir a decisão impugnada por outra, pois, assim, estaria prevista como verdadeiro recurso ${ }^{12}$.

Nesse ponto, é curioso que, ao pronunciar a validade da correição parcial instituída no seio de legislações estaduais, o Supremo Tribunal Federal tenha-se pautado exatamente pelo fato de o instituto estar previsto na antiga Lei do Mandado de Segurança. Ou seja, a lei que veio formalizar um instrumento que já vinha sendo utilizado com nítido viés

\footnotetext{
${ }^{10}$ MonIZ DE ARAGÃo, ob. cit., p. $42-43$.

${ }^{11}$ Interessante notar que, embora o texto da lei diga "correção", o acórdão do Supremo Tribunal Federal, pelo qual se considerou constitucional essa restrição ao cabimento do mandamus, refere-se a "correição" (RMS 11.964, Rel. Min. Victor Nunes Leal, j. 17/06/1964). Assim, também, Celso AgRícola BARBI, ao afirmar que "entende a lei que não existe esse interesse quando o ato pode ser atacado por recurso ou correição" (Do Mandado de Segurança, p. 105). Não seria desarrazoado supor que, ao se referir a "correção", o texto legal pretendesse tratar, por exemplo, dos erros formais corrigíveis ex officio, a exemplo da previsão do artigo 285 do CPC de 1939. Do mesmo teor é o verbete 267 da Súmula do STF: "Não cabe mandado de segurança contra ato judicial passível de recurso ou correição".

${ }^{12} \mathrm{Na}$ verdade, a intenção da lei foi vedar o uso do mandamus quando houvesse medida jurisdicional ou administrativa eficaz a sustar o dano ao direito líquido e certo. Em outras palavras, existindo recurso ou correição capaz de impedir (ou postergar) a violação que a decisão impugnada poderia gerar a direito líquido e certo, incabível o remédio constitucional (MEIRELLES, Hely Lopes; WALD, Arnoldo; Mendes, Gilmar Ferreira. Mandado de segurança e ações constitucionais, p. 43-44).
} 
recursal - extrapolando, portanto, seus limites disciplinares e hierárquicos ${ }^{13}-$ serviu de fundamento exatamente para que se considerasse legítima a sua pretérita utilização ${ }^{14}$.

Posteriormente, a Lei de Organização Judiciária da Justiça Federal (Lei Federal 5.010/1966) passou a prever a competência do Conselho da Justiça Federal, à época integrado pelo Presidente, Vice-Presidente e mais três ministros do Tribunal Federal de Recursos, para "conhecer de correição parcial requerida pela parte ou pela Procuradoria da República, no prazo de cinco dias ${ }^{15}$, contra ato ou despacho do Juiz de que não caiba recurso ou omissão que importe em erro de ofício ou abuso de poder”.

Embora afirmasse que a inconstitucionalidade deveria cessar com a previsão da correição parcial nas citadas leis federais, MONIZ DE ARAGÃo entendia persistir a contradição do instituto com os princípios que nortearam as leis processuais da época, em especial o da oralidade e da efetividade da tutela jurisdicional. Assim se expressou por entender que, diante do largo cabimento do agravo no CPC/39, não fazia sentido permitir que as partes, via correição parcial, acabassem recorrendo dos “despachos interlocutórios que a lei quis que fossem irrecorríveis" ${ }^{, 16}$.

Renitente pela inconstitucionalidade das correições estaduais, ARRUDA ALVIM afirmava que, "se a lei é, por sua natureza, de organização judiciária, e, assim, necessariamente limitada a tais finalidades, e se o local do instituto da correição, nessa Lei, não deixa dúvida que se trata de medida disciplinar, é evidente que a referida interpretação

\footnotetext{
${ }^{13}$ MONIZ DE ARAGÃo assim se expressou em 1969: "dadas as suas características, a correição parcial é um recurso propriamente dito, pois os limites administrativos em que deveria situar-se estão de há muito superados na jurisprudência dos tribunais" (ob. cit., p. 42).

${ }_{14}$ Do voto do relator, se extrai: "Não importa que se trate, no caso, de recurso de natureza administrativa [contra a decisão do Corregedor na correição parcial ou reclamação], previsto na Lei de Organização Judiciária. Esse recurso do ato do Corregedor para o Conselho é uma das etapas do processo correicional previsto na Lei Judiciária Amazonense. E o Supremo Tribunal já tem afirmado, reiteradamente, que é válido o processo de correição, regulado em lei estadual, porque a ela se refere expressamente o art. $5^{\circ}, \frac{e}{I I,}$ da L. 1.533, de 1951, que foi baixada pelo legislador federal" - destaque nosso (RMS 11.964, Rel. MiN. VICTOR NUNES LEAL, j. 17/06/1964). A Lei 12.016/2009, em dispositivo de mesma numeração, manteve apenas a proibição relativa ao cabimento de recurso com efeito suspensivo (art. $5^{\circ}$, II).

${ }_{15}^{15}$ Prazo acrescido pelo Decreto-lei 253, de 28/02/1967.

${ }^{16}$ Ob. cit., p. 44. Já mais recentemente TERESA ARRUDA Alvim PINTO, "as correições em tese são, de fato, vocacionadas a verificar da regularidade dos serviços forenses. Se gerais, têm por objeto todos os processos ou uma significativa amostragem; se parciais, um processo, em especial, sempre com o fito de corrigir inversão procedimental e erros, no processo" (Mandado de segurança contra ato judicial, p. 62).
} 
é inaceitável" ${ }^{\prime 17}$.Note-se, aqui, a relação existente entre a natureza jurídica emprestada ao instituto e sua constitucionalidade.

Vale apontar, também, que, mesmo depois da promulgação do Código de Processo Civil de 1973, a jurisprudência do Supremo Tribunal Federal continuou vendo constitucionalidade nas correições parciais previstas nos regimentos dos tribunais ${ }^{18}$, em flagrante aceitação dessa medida cuja eficácia já tinha se expandido, havia tempo, para além das funções meramente administrativas.

A verdade é que, hoje, quase todos os Tribunais Estaduais ${ }^{19}$ e Tribunais Regionais Federais ${ }^{20}$ do País preveem em seus Regimentos Internos algum instrumento voltado a colocar ordem no processo ${ }^{21}$ ou a fazer valer as suas próprias decisões e o respeito à sua competência, quando não estão previstos mais de um deles, cujos nomes variam entre reclamação, correição parcial e representação.

${ }^{17}$ Correição parcial, p. 12. No mesmo sentido: MARIA LúCIA MEDEIROS, Anotações sobre a correição parcial, p. 132.

${ }^{18}$ Por exemplo, no RE 84.965, relatoria do MINISTRO SOARES MUÑOZ, julgado em 15/05/1979, admite-se a reclamação correicional contra ato omissivo de juiz, corporificado no proferimento prematuro de determinado despacho, omitindo outro que o deveria anteceder. O relator afirma em seu voto que o novo estatuto processual, apesar de haver procurado conceder agravo de instrumento a todas as interlocutórias, não o conseguira inteiramente, nas hipóteses de atos omissivos dos juízes.

${ }^{19}$ É caso, por exemplo, dos Tribunais do Paraná, de São Paulo, Rio de Janeiro e Minas Gerais. No Rio de Janeiro, há dois tipos de reclamação bem definidos no Regimento Interno do TJ: um, previsto ao lado da representação por excesso de prazo, aplicável contra membro do próprio tribunal e com nítido viés disciplinar, e outro, previsto nos artigos 210 a 215, para os casos de omissões ilegais ou inversão da ordem legal do processo ou resultem de erro de ofício ou abuso de poder. Não se vê a reclamação para fazer valer as decisões ou para preservar sua competência. No Rio Grande do Sul, o RITJ prevê a representação por excesso de prazo (art. 335), enquanto a correição parcial é regulada pela Lei de Organização Judiciária do Estado (art. 251 do RITJRS), cujo texto é quase idêntico ao do RITJPR. Em MG, o RI do TJ, prevê tanto a correição parcial (art. 290) quanto a representação por excesso de prazo (art. 294). Na Bahia, o RITJ disciplina tanto a correição parcial (arts. 245 a 247) quanto à reclamação (arts. 248 a 253); a primeira visa à correção de atos judiciais que importem na subversão ou tumulto da ordem processual ou embaracem o andamento dos feitos, se não houver recurso previsto com efeito suspensivo, e a segunda é destinada a preservar a competência do Tribunal ou garantir a autoridade das suas decisões. Em São Paulo, também estão previstas a reclamação (arts. 192 a 196) e a correição parcial (arts. 208 a 212); enquanto a primeira é versada identicamente à da Lei 8.038/90, ou seja, com a mesma natureza da prevista na Constituição Federal, a segunda, embora se mantenha fiel à tradição de ser cabível contra atos que provoquem a inversão tumultuária do processo (vícios formais), só é aplicável ao processo criminal e desde que não caiba recurso.

${ }^{20}$ Os TRFs da $1 .{ }^{a}$ e $4 .{ }^{a}$ Regiões preveem, respectivamente, o cabimento de correição parcial, com vistas a corrigir "ato ou despacho de juiz de que não caiba recurso, bem como de omissão que importe erro de ofício ou abuso de poder" (art. 269 do RITRF1) e visando "à emenda de erros ou abusos que importem a inversão tumultuária de atos e fórmulas legais, a paralisação injustificada dos feitos ou a dilação abusiva dos prazos por parte dos Juízes de Primeiro Grau, quando, para o caso, não haja recurso previsto em lei" (art. 263). Mas os demais TRFs, da 2. ${ }^{a}, 3 .{ }^{a} \mathrm{e} 5 .{ }^{a}$ Regiões nada preveem.

${ }^{21}$ De acordo com MoNIZ DE ARAGÃo, "instaura a desordem processual, portanto, originando uma inversão tumultuária que autoriza o remédio da correição parcial, o ato do Juiz que paralise, retroceda, encurte, distenda, desvie ou elimine atos da marcha normal do processo, tal como descrita no Cód. De Proc. Civil ou em leis especiais" (ob. cit., p. 82). 
A propósito das representações, embora se lastreiem, hoje, nos artigos 198 e 199 do Código de Processo Civil, é inegável que sua natureza coincide com a das correições parciais, na medida em que se destinam a colocar ordem no procedimento, embora tratem de uma matéria específica, qual seja o excesso de prazo. Em outras palavras, todos esses instrumentos, de origem administrativo-disciplinar, têm o mesmo objetivo de colocar ordem no processo, abrindo oportunidade para a aplicação, em outro procedimento, de sanções administrativas aos juízes responsáveis.

Hoje, nitidamente, há dois tipos de reclamação previstos nos Regimentos Internos dos Tribunais: uma, às vezes chamada de correição parcial, ficou presa à sua origem correicional e é voltada a corrigir a rota do procedimento; outra, já inspirada na que é prevista na Constituição de 1988, tem objetivo específico de guardar a competência do respectivo Tribunal e garantir a autoridade de suas decisões. Ambas, contudo, retiram sua legitimidade e sua força da própria estrutura hierarquizada do Poder Judiciário, pois, diferentemente da que vem prevista na Constituição, essas reclamações só são cabíveis contra atos judiciais.

\subsubsection{A reclamação constitucional}

Foi José DA SILva PACHeCo quem primeiro traçou a linha evolutiva, definindo alguns marcos da caminhada da reclamação rumo à sua constitucionalização, que a doutrina subsequente acolheu e vem transmitindo até hoje. O autor dividiu a história da reclamação em quatro fases: (1) antes da previsão do RISTF; (2) após a previsão no RISTF (em 2.10.57) até a Constituição Federal de 1967; (3) da CF/1967 até a promulgação da Carta Política de 1988; (4) a partir da constitucionalização do instituto ${ }^{22}$.

Seguindo essa trilha, MARCELO NAVARro RIBEIRO DANTAS ${ }^{23}$ vislumbrou a possibilidade de subdividir a terceira fase em duas: (3.1) do advento da CF/1967 até a

\footnotetext{
${ }^{22}$ A "reclamação" no STF e no STJ de acordo com a nova Constituição, p. 19.

${ }^{23} \mathrm{O}$ autor traça o itinerário da evolução do instituto de forma primorosa, cuja leitura se recomenda aos que pretenderem se aprofundar nas raízes jurisprudenciais do instituto. Notar-se-á a força das construções dos Tribunais na solução de problemas de ordem prática não vislumbrados pelo legislador ou, até, se notados, desconsiderados por ele na criação das leis (Reclamação Constitucional, p. 45-264). Como a obra foi editada em 2000, o autor deixa de tratar da reclamação criada pela EC 45/2004. Em texto mais recente, todavia, a utilização prevista no artigo 103-A, §3. ${ }^{\circ}$, da CF é visitada por ele (Novidades em reclamação constitucional: seu uso para impor o cumprimento de súmula vinculante, inMEDINA, José Miguel Garcia et al. (coord.).Os
} 
edição da EC 7/1977, que denomina fase de consolidação, e (3.2) da EC 7/1977 até a promulgação da CF/1988. Nesse passo, subdivide a história da reclamação em cinco fases evolutivas, que nomeia, respectivamente, de: fase de formulação do instituto, fase de discussão, fase de consolidação, fase de definição e, por último, fase de plenificação constitucional da reclamação.

Preferiremos, contudo, dados os objetivos do presente trabalho, guiarmo-nos pelas fases traçadas por JosÉ DA SILVA PACHECO, que são suficientes para a compreensão da evolução da reclamação e para o debate sobre sua natureza jurídica.

\subsubsection{A formulação do instituto}

Ao se tratar da fase que precedeu a previsão regimental no STF, costuma-se apontar que a reclamação constitucional voltada à preservação da competência e da autoridade das decisões dos tribunais é construção jurisprudencial do Supremo Tribunal Federal a partir da teoria dos poderes implícitos do direito norte-americano ${ }^{24}$. Mas, na verdade, essa teoria serviu apenas de fundamento para utilizar a reclamação correicional já existente para fim diverso, justificando seu uso com nítido viés jurisdicional.

Referida teoria nasceu no início do século XIX nos EUA a partir de uma decisão da Suprema Corte no caso MacCulloch x Maryland, em que se discutia a possibilidade de um estado federado taxar uma instituição financeira criada pela União de modo a quase impedir o exercício da atividade. Esse precedente, sempre citado como matriz da teoria dos "implied powers", na realidade, tratava, em seu bojo, de conflito de competências entre um estado federado e a União federal, embora tenha-se originado da recusa por parte de James William McCulloch, então caixa da agência do Banco Federal na cidade de Baltimore (Estado de Maryland), de selar papeis e recolher tributos instituídos pelo governo estadual.

A respeito do tema, após sumarizar o caminho que levou as colônias norteamericanas a se unirem em federação, ADHEMAR FERREIRA MACIEL ${ }^{25}$ opta por dar enfoque diferente ao referido precedente; para ele, o julgamento cuidou de confirmar o princípio da

poderes do juiz e o controle das decisões judiciais: estudos em homenagem à professora Tereza Arruda Alvim Wambier. São Paulo: RT, 2007, p. 1174-1187).

${ }^{24}$ Assim: SILVA PACHECO, A "reclamação" no STF e no STJ de acordo com a nova Constituição, p. 19; RIBEIRO DANTAS, Reclamação constitucional no direito brasileiro, p. 144-190; LEONEL, Reclamação constitucional, p. 112-113.

${ }^{25}$ Poderes reservados versus poderes implícitos, p. 4-5. 
supremacia federal: "no caso concreto, como havia conflito entre normas estaduais e federais, prevaleciam as últimas" ${ }^{, 26}$.

$\mathrm{O}$ autor ensina que a maioria dos constituintes de 1787 temia um governo central forte, o que os levou a adotar a técnica dos “poderes enumerados" (enumerated powers), ou seja, a competência da nova entidade política (Estados Unidos) viria expressa, e apenas o que não viesse enumerado ou taxativamente proibido seria reservado aos estados ${ }^{27}$.

Todavia, como bem anota JosÉ DA SILVA PACHECO, a reclamação não possui uma origem só, mas foi uma construção paulatina da jurisprudência do Supremo, lastreada em outras várias influências: do Direito Romano, em que se admitia a supplicatio, a partir da cognitio extra ordinen; do nosso Direito antigo, em que se contemplava o agravo de ordenação não guardada das Ordenações Filipinas e o agravo por dano irreparável do Regulamento 737; do direito de organização judiciária dos Estados, que incluía a correição parcial, principalmente pela do antigo Distrito Federal; do mandado de segurança contra atos de autoridade judicial, a partir de 1934; do atentado contra ato judiciário ${ }^{28}$.

O julgamento da Reclamação 141, ocorrido em 25de janeiro de 1952, é um marco na evolução da jurisprudência do STF e trouxe novas luzes à questão. Cuidava-se de hipótese em que uma decisão do Tribunal de Justiça de São Paulo estaria descumprindo julgado do Supremo. Colhe-se, do voto do Ministro Rocha LAGOA, a seguinte afirmação: "tudo que for necessário para fazer efetiva alguma disposição constitucional, envolvendo proibição ou restrição ou a garantia a um poder, deve ser julgado implícito e entendido na própria disposição".

\footnotetext{
${ }^{26}$ A propósito, vale trazer trecho do acórdão da Suprema Corte Norte-americana: "The court has bestowed on this subject its most deliberate consideration. The result is a conviction that the states have no power, by taxation or otherwise, to retard, impede, burden, or in any manner control, the operations of the constitutional laws enacted by congress to carry into execution the powers vested in the general government. This is, we think, the unavoidable consequence of that supremacy which the constitution has declared. We are unanimously of opinion, that the law passed by the legislature of Maryland, imposing a tax on the Bank of the United States, is unconstitutional and void"(disponível em: 〈http://openjurist.org/17/us/316〉. Acesso em: 1. ${ }^{\circ}$ jul. 2014). Mas não foi a primeira vez em que o STF se valeu nessa teoria. Segundo EvandRo LiNS E SILVA, na primeira vez em que recebeu um recurso extraordinário com efeito suspensivo, o STF agiu sem base legal, apenas sob o argumento dos poderes implícitos. E, pela mesma razão, o autor entende ser possível defender, na vigência da atual Constituição, o cabimento da avocatória ( $O$ salão dos passos perdidos, p. 405406).

${ }^{27}$ Idem, ibidem, p. 4.

${ }^{28}$ Ob. cit., p. 19.
} 
Na mesma oportunidade, o MinISTRO NELSON HUNGRIA afirmara que "a reclamação, dentro do estrito ponto de vista em que a admito, vai encontrar base até no preceito constitucional sobre o direito de representação", pois "não se trata de recurso, mas de simples representação, em que se pede ao STF que faça cumprir o seu julgado tal como nele se contém". Segundo o Ministro, “tanto não é recurso, no sentido técnico, que vários Estados a têm instituído em suas leis de organização judiciária, mesmo com intensos objetivos de correição forense".

Vale dar especial atenção ao argumento utilizado por NELSON HUNGRIA, baseado na previsão constante na Lei do Mandado de Segurança, que "oficializou, indiretamente, o expediente da reclamação correicional perante as instâncias superiores, ao dispor que esse writ somente cabe, quando se trata de ato judicial, se não couber recurso com efeito suspensivo ou não for o ato passível de correição, ou seja, de reclamação".

Calha, ainda, trazer o fundamento apresentado pelo Ministro OrOZIMBO NONATO, ao votar pelo cabimento da reclamação. Segundo ele, "há um princípio pacífico em Direito: o de que a sentença deve ser cumprida fielmente, pontualmente, estritamente". Para o Ministro, então, a solução era muito mais simples e repousava na constatação de que de o cabimento da reclamação para fazer valer as decisões judiciais encontrava amparo na própria efetividade da tutela jurisdicional. Ou seja, de nada adianta atribuir poder jurisdicional a um órgão - seja ele de primeiro grau seja o Supremo Tribunal Federal - se suas decisões puderem ser descumpridas sem que haja um meio eficaz de forçar o seu cumprimento.

O Ministro Hannemann Guimarães batia-se pelo descabimento da reclamação, com os seguintes argumentos: a) não haver previsão regimental; b) não ser idêntica à correição, que, "como processo administrativo, limita-se a corrigir irregularidades processuais por abuso ou por ilegalidade das autoridades judiciárias ou dos funcionários do cartório"; c) por não se equiparar ao mandado de segurança, que pressupõe decisão judicial de que não caiba recurso; d) porque, para anular a sentença, há a ação rescisória ${ }^{29}$.

Entretanto, apesar de não serem idênticas, era inegável que o móvel de ambas as medidas era o mesmo, qual seja fazer valer uma decisão descumprida. A natureza do vício a ser corrigido via reclamação é a mesma daqueles consertados pelas correições parciais,

${ }^{29}$ PACHECO, A “reclamação" no STF e no STJ de acordo com a nova Constituição, p. 21. 
que eram usadas em casos de descumprimento pelo juiz de piso da decisão tomada pelo Tribunal.

Vê-se que, apesar daquela variedade de influências estar na base da construção da reclamação, seu principal ancestral foram mesmo as correições parciais estaduais ou as chamadas reclamações correicionais, baseadas no direito de representação ou petição (art. $141, \S 37$, da $\mathrm{CF} / 1946^{30}$ ). O que o Supremo discutia na época, então, era menos a origem do instituto que sua natureza jurídica, pois decorrer dos poderes implícitos do Direito Norte-americano pode significar que tanto aqui quanto lá existem medidas que são gestadas para fazer valer algum poder que esteja sendo descumprido.

\subsubsection{A inclusão no Regimento Interno do STF}

Com espeque na previsão do artigo 97, II, da Constituição de 1946, que permitia aos Tribunais a elaboração de seus Regimentos Internos, a reclamação foi incluída pelo Supremo na sessão de 2 de outubro de 1957, embora ainda pairassem dúvidas a respeito de sua natureza jurídica, como se colhe da própria proposta de alteração do Regimento formulada pelos Ministros LAFAYETTE DE ANDRADA e RIBEIRO DA COSTA:

"a medida processual de caráter acentuadamente disciplinar e correicional denominada reclamação, embora não prevista, de modo expresso, no art. 101, I a IV, da Constituição Federal, tem sido admitida no Supremo Tribunal Federal, em várias oportunidades, exercendo-se, nesses casos, sua função corregedora, a fim de salvaguardar a extensão e os efeitos de seus julgados, em cumprimento dos quais se avocou legítima e oportuna intervenção" ${ }^{\text {31 }}$.

Como se vê, a proposição assume a natureza processual da medida, embora reconheça sua função corregedora, quando se sabe que medidas correicionais são administrativas por excelência, não podendo ser confundidas com instrumentos jurisdicionais.

No entanto, são dessa segunda fase os primeiros julgados que começam a excluir o cabimento da reclamação nas hipóteses em que era cabível, de ordinário, a correição parcial. Erros e tumultos processuais, para os quais se aceitava a reclamação correicional,

\footnotetext{
30 "§ 37. É assegurado a quem quer que seja o direito de representar, mediante petição dirigida aos Poderes Públicos, contra abusos de autoridades, e promover a responsabilidade delas".

${ }^{31}$ MeIRELLES, WALD e MENDES, Mandado de segurança e ações constitucionais, p. 809 e 810.
} 
não serviam como fundamento para a reclamação prevista no RISTF, a qual passou a ter somente a dupla finalidade de assegurar a autoridade dos julgados e de preservar a competência do Tribunal ${ }^{32}$.

A propósito do estágio de desenvolvimento do instituto nessa fase, MARCELO RIBEIRo DANTAS, após esmiuçar os votos dos 15 Ministros no julgamento da Reclamação 691/SP, relator oMinistro CARLOS MedeIROS SiLVA, afirmou que o Supremo prosseguia no "lento e complicado processo de libertação da reclamação, que instituíra regimentalmente, daquela medida de mesmo nome, que quiçá a tenha, originalmente inspirado, mas de cuja natureza, alcance e objetivos ia ficando cada vez mais apartada” ${ }^{\text {}}$.

Na verdade, a inclusão no Regimento aplacou algumas críticas relativas à ausência de previsão legal do instituto, ou seja, serviu apenas para regulamentar a técnica já usada pelo Supremo sem grandes problemas, mas, do ponto de vista do delineamento do conceito, esse estágio serviu apenas para dar início de definição do objeto da reclamação perante o Supremo Tribunal Federal.

\subsubsection{Constituição Federal de 1967: consolidação da hipótese regimental}

A terceira fase do processo de engendramento da reclamação constitucional inicia-se com a previsão, no artigo 115, parágrafo único, $c$, da CF/1967, da autorização para que o RISTF pudesse estabelecer "o processo e o julgamento dos feitos de sua competência original ou recursal e da arguição de relevância da questão federal", o que a EC 1/1969 não modificou. Dava-se, assim, ao Supremo o poder de legislar em matéria processual relativa a demandas de sua competência e abria-se a porta para admitir, sem receios, a natureza processual da reclamação, que se distanciou de vez das origens correicionais.

\footnotetext{
${ }^{32}$ Dessa época, encontram-se interessantes julgados, como, por exemplo, o acórdão da Rcl. 371, rel. MiN. ANTÔNIO VILLAS BOAS, no qual se decidiu que "não é possível obter, mediante reclamação, a ampliação de um julgado, sem cunho normativo, a casos pretensamente iguais" (Apud DANTAS, ob. cit., p. 192-193). O autor menciona, também, que, nesse período, ainda era possível encontrar o termo "reclamação" sendo usado sem o menor rigor teórico, para significar simples pedido de reconsideração (AG 21542-RJ, rel. MIN. HENRIQUE D'ÁvILA, j. 13/10/1959), bem como o primeiro caso em que a reclamação foi usada para cassar decisão de Tribunal que negava trânsito a recurso extraordinário (Recl. 498, rel. Min. LuIZ GALLOTTI, j. 10/12/1962).

${ }^{33}$ Ob. cit., p. 198-207. Trata-se de caso interessante, no qual se apresentou reclamação contra ato do Senado consistente em revogar resolução que acatara comunicação relativa à inconstitucionalidade de determinada lei, hipótese em que o ato significaria descumprimento da decisão do Supremo. O Tribunal entendeu não cabível a reclamação, pois sua feição correicional a tornava inviável para corrigir atos de outros Poderes.
} 
Embora essa previsão constitucional tenha servido para colocar uma pá de cal nas discussões a respeito da legitimidade da reclamação prevista no Regimento Interno do STF, o mesmo efeito não se sentiu no que diz com o debate a respeito do conceito do instituto, já que foi nesse período que a preocupação de definir a verdadeira natureza jurídica da reclamação regimental do STF chegou definitivamente ao Tribunal, onde a disputa era basicamente entre os que se apegavam em conceituá-la como medida meramente correicional (administrativo-disciplinar na origem) e os que já se tinham apercebido que outro instituto - de natureza processual - nascera $\mathrm{ali}^{34}$.

Durante a vigência da Carta outorgada em 1967, podemos destacar alguns julgados do Supremo nos quais o Tribunal discutiu a natureza da reclamação e seu cabimento. Merecem destaque, por exemplo, acórdãos que cuidavam dos limites do objeto da reclamação, já expondo a opinião da época segundo a qual não era possível estender um julgado do Supremo para outros casos, mesmo que idênticos, que não tivessem sido objeto de decisão, ou seja, a reclamação não salvaguardava a tese fixada, mas apenas o dispositivo do acórdão ${ }^{35}$. No mesmo sentido, decidiu-se que não procede a reclamação quando, alegando descumprimento de acórdão do STF, visasse, na realidade, a fazer cumprir algo não abrangido, explícita ou implicitamente, nele $^{36}$.

Vale destaque, também, o julgamento da Reclamação 831/DF, de relatoria do Ministro MoACYR AMARAL SANTOS, em 11 de novembro de 1970, que foi um divisor de águas no que diz respeito à definição da natureza jurídica da reclamação prevista no Regimento Interno do STF. Na ocasião, não apenas se analisou a natureza da medida, mas também as suas hipóteses de cabimento, seus requisitos e seus objetivos. A ementa do acórdão trazia que "a finalidade da reclamação é a de preservar a integridade da competência do Supremo Tribunal Federal ou assegurar a autoridade do seu julgado", e que "terminada a instância, isto é, entregue a prestação jurisdicional e posto termo à relação processual, não se há como falar em reclamação".

Definiram-se os seguintes pressupostos, portanto: a) existência de relação processual em curso, o que vedava seu uso em caso de decisão trânsita; b) um ato que se ponha contra a competência do Supremo ou contrarie decisão proferida nessa relação processual ou em

\footnotetext{
${ }^{34}$ DANTAS, ob. cit., p. 211.

${ }^{35}$ Rcl. 726/RS, rel. Ministro LuIZ GALlOtTI, j. em 05/03/1969.

${ }^{36}$ Rcl. 30/PI, rel. MiNISTRO MOREIRA ALVES, j. em 08/10/1975.
} 
relação processual que daquela dependa. E, por fim, decidiu-se que "não cabe reclamação, uma vez que não haja ato processual contra o qual se recorra, mas um ato administrativo, que, se violento ou ilegal, tem por remédio a ação própria, inclusive o mandado de segurança”. Esses pressupostos levaram MOACYR AMARAL SANTOS a configurar a reclamação muito mais aproximada do recurso que da ação. Afirmou ele: "reclama-se, recorre-se contra um ato da relação processual em curso".

Vem dessa época, também, o entendimento segundo o qual a reclamação não pode ser usada como simples sucedâneo recursal ${ }^{37}$, expondo um cuidado para evitar o que a doutrina tem chamado de banalização do instituto, receio que se revigora a cada dia no Supremo Tribunal Federal ${ }^{38}$.Aos poucos, com esses debates cada vez mais constantes, sedimentava-se a distinção entre as reclamações regimentais dos Tribunais subalternos e a reclamação cabível perante o Supremo Tribunal Federal ${ }^{39}$.

Também nesse período, o Tribunal se deparou com a questão da legitimidade para a propositura da reclamação nos casos em que o acórdão paradigma foi proferido em sede de Representação de Inconstitucionalidade ${ }^{40}$. Se, de um lado, não se poderia negar o uso da reclamação aos legitimados extraordinários da Representação, por outro, ao aceitá-la, criava-se um problema de difícil solução: como negar que todos os afetados pela declaração de constitucionalidade também seriam "interessados na causa", nos termos do quanto dispunha e ainda dispõe o artigo 156 do Regimento Interno ${ }^{41}$

\footnotetext{
${ }^{37}$ Rcl. 31/SP, rel. MiNISTRO DJACI FALCÃO, j. em 15/05/1974.

${ }^{38 ،}$ “O remédio constitucional da reclamação não pode ser utilizado como um (inadmissível) atalho processual destinado a permitir, por razões de caráter meramente pragmático, a submissão imediata do litígio ao exame direto do Supremo Tribunal Federal" (STF,Rcl. 6534 AgR/MA, Plenário, Rel. MiN. CELSO DE MeLlO, j. 25/09/2008, DJe 19/10/2008). "É que a reclamação - constitucionalmente vocacionada a cumprir a dupla função a que alude o art. 102, I, "l”, da Carta Política (RTJ 134/1033) - não se qualifica como sucedâneo recursal, nem configura instrumento viabilizador do reexame do conteúdo do ato reclamado, eis que tal finalidade revela-se estranha à destinação constitucional subjacente à instituição dessa medida processual" (STF, Rcl. 2107 AgR/SC, 2. ${ }^{\text {a }}$ T., Rel. MiN. CElso DE MELlo, j. 05/08/2014, DJe 02/09/2014).

39 Já no julgamento da Rcl. 43/GB, rel. MiNISTRO THOMPSON FLORES, o Tribunal assentou que a reclamação regimental do Supremo era inviável para declarar nulidades processuais supostamente ocorridas em instâncias inferiores - para correção das quais o Tribunal admitia a correição parcial - em face da inexistência de qualquer relação entre elas e as hipóteses de cabimento previstas no Regimento.

${ }^{40}$ O julgamento da Rcl. 136/GO, da relatoria do MinISTRO SOARES MunHOZ, realizado em 26/05/1982, expressa o pensamento do Supremo à época, mostrando a angústia da Corte em negar a possibilidade de utilização da reclamação em casos de controle concentrado, por ainda estar presente a ideia de sua natureza correicional. O Tribunal começava a notar que não mais poderia tratar a reclamação como instrumento meramente inter partes, já que o problema não era mais de limites legitimidade mas sim de limites da eficácia de suas decisões, que, tomadas em sede de controle concentrado, afetavam a todos, indistintamente.

${ }^{41}$ Ao votar, na Rcl. 136, o MIN. NÉRI DA SILVEIRA insinuou que seria um contrassenso o STF aceitar "interessados" ao lado do autor da Representação de Inconstitucionalidade, como vinha aceitando, e não
} 
No entanto, prevaleceu uma corrente jurisprudencial que, ao que tudo indica, tende a renascer no Supremo Tribunal Federal ${ }^{42}$. Tal posição distinguia os "atos de índole política necessários à produção dos efeitos da decisão declaratória de inconstitucionalidade", restringindo a posição de reclamante apenas ao autor das ações diretas (o Procurador-Geral da República), e as "situações resultantes da irradiação dos efeitos da decisão do STF, em representação julgada procedente, no plano de direitos ou interesses jurídicos, de particulares ou de pessoas jurídicas de direito público, nascidos da incidência da norma, tida como inválida", as quais os interessados deveriam tratar "nas vias próprias de proteção desses alegados direitos e interesses" $" 43$.

A questão sobre a natureza jurídica, todavia, não se tinha pacificado ainda, quando, em 31 de outubro de 1984, como bem pontua MARCELO RIBEIRO DANTAS ${ }^{44}$, o Supremo profere a mais importante decisão acerca da reclamação, na qual as discussões se aprofundaram de maneira nunca antes vista na jurisprudência sobre o tema.

Fala-se do julgamento da Representação 1092/DF, na qual se discutia a constitucionalidade do dispositivo do Regimento Interno do Tribunal Federal de Recursos que previa o cabimento de reclamação nos mesmos moldes da prevista no RISTF, sob o argumento de que somente o Supremo poderia, com supedâneo no texto constitucional então vigente, tratar de matéria processual em seu regimento. Vale frisar ter sido nesse processo que o Instituto dos Advogados Brasileiros (IAB), na condição de assistente, fez juntar parecer de JOSÉ FREDERICO MARQUES no qual este manifesta seu clássico

aceitar esses mesmos sujeitos - ainda que não tivessem ingressado na ação de controle concentrado - como reclamantes, em caso de descumprimento do quanto decidido no tocante à constitucionalidade. Vale lembrar que, hoje, o artigo 13 da Lei 8.038/90 se refere a "parte interessada", expressão um pouco mais restrita que "interessados na causa".

${ }^{42}$ Referimo-nos ao quanto decidido na Rcl. 4335/AC, rel. MiN. GILMAR MENDES, j. 20/03/2014, DJe 23/10/2014.

${ }^{43}$ Voto do rel. MIN. NÉRI DA SILVEIRA, no julgamento da RclQO 235/MA. Na mesma ocasião, o MIN. OSCAR CORRÊA assumiu ter dúvidas em relação ao tema, preferindo acompanhar o relator, mas por não reconhecer, no reclamante, a situação de "interessado na causa", ou seja, por não o ter como possível "assistente", em tese, do autor da representação. Consigne-se, ainda, a posição do MIN. MOREIRA ALVES pelo descabimento mesmo da reclamação para "garantir a autoridade" da decisão em sede de controle concentrado, firme na ideia que dá sentido estrito à expressão, para entendê-la como cabível apenas em casos nos quais houver necessidade de execução prática do comando da decisão do Supremo, verbis: "Essa garantia só se verifica quando, em execução, se atenta contra o decidido por esta Corte, o que não pode ocorrer em representação de inconstitucionalidade cuja decisão não é executável. A declaração de inconstitucionalidade não é suscetível, por si mesma, de execução, e se a lei declarada inconstitucional vier a ser aplicada, a solução é de alegar-se judicialmente que se está aplicando a caso concreto lei nula, o que dá margem até a recurso extraordinário" (STF, RclQO 235/MA, rel. Min. NÉRI DA SILVEIRA, v. u., j. 1. \%/10/1987).

${ }^{44}$ Ob. cit., p. 227-257. 
entendimento sobre a natureza jurídica da reclamação, para tê-la como instrumento recursaliforme, ou seja, sucedâneo recursal.

Depois de grande discussão, com vários pedidos de vista, o Supremo acompanhou o entendimento do relator, pela impossibilidade de, perante a Constituição então vigente, outros tribunais criarem, via regimento interno, hipótese de cabimento de reclamação como prevista no RISTF, único tribunal com autorização constitucional para fazê-lo. Da ementa do acórdão, extrai-se:

"como quer que se qualifique - recurso, ação, ou medida processual de natureza excepcional, é incontestável a afirmação de que somente ao Supremo Tribunal Federal em face primacialmente, da previsão inserida no art. $119, \S 3 .^{\circ}$, letra $c$, da Constituição da República, é dado no seu Regimento Interno, criar tal instituto, não previsto nas leis processuais".

Registre-se que o Supremo perdeu, a nosso ver, a chance de reconhecer na reclamação regulada no seu Regimento Interno, seja que natureza se lhe empreste, a função primordial de fazer valer a ordem processual vigente e, assim, reconhecê-la como instrumento naturalmente inserido no direito à tutela jurisdicional efetiva, já previsto na ordem constitucional em vigor.

O mais importante, no entanto, é que, a partir do debate levado a efeito nesse julgamento, deixou de existir qualquer confusão entre a reclamação prevista no seu Regimento Interno e a correição parcial, tanto que praticamente desapareceu dos arestos do Supremo $^{45}$.

Na época, o entendimento dominante no Supremo era no sentido da residualidade da reclamação, afirmando ser cabível apenas quando não fosse possível recorrer, impetrar mandado de segurança ou ajuizar rescisória ${ }^{46}$.No mesmo sentido, parece ter sido proclamado que, havendo possibilidade de utilização da suspensão de liminar contra decisão de Tribunal de Justiça que aplicasse dispositivo legal cuja eficácia estava suspensa por liminar concedida em Representação (embrião da ação direta), não seria caso de reclamação ${ }^{47}$.Assemelhava-se a medida, portanto, ao mandado de segurança contra ato judicial, só cabível à falta de recurso previsto ou de correição.

\footnotetext{
${ }^{45}$ DANTAS, ob. cit., p. 257.

${ }^{46}$ Rcl. 245/RJ, Pleno, rel. Min. CARlos MADEIRA, j. 18/12/1987.

${ }^{47}$ Rcl.176/SP, Rel. MIN. MoREIRA AlVES, j.05/06/1985.
} 
Ainda antes da promulgação da CF/1988, o Supremo já enfrentara a possibilidade de utilização da reclamação para garantir a autoridade de decisão do Supremo dotada de eficácia erga omnes, eis que proferida em sede de representação de inconstitucionalidade em tese. Veja-se a ementa:

contra ato judicial que aplica norma declarada inconstitucional pelo Supremo Tribunal Federal em representação de inconstitucionalidade não cabe reclamação, pela parte prejudicada naquela relação processual, sob o fundamento de, como terceiro interessado, visar a garantir a autoridade da decisão desta Corte ${ }^{48}$.

Segundo MARCElo DANTAS, o maior problema para aceitar o uso da reclamação naquelas hipóteses decorria da "circunstância de ser o processo de ação direta referente a controle de constitucionalidade, como se usa dizer, um processo objetivo, sem partes no sentido próprio do termo", ao mesmo tempo em que "a decisão nele produzida atinge a todos, inclusive aqueles que sequer figuraram na relação processual da ação direta". Ocorre que, lembra em arremate, "se há, posteriormente, ato que contrarie tal decisão, em rigor está havendo vulneração de decisum do Supremo, caracterizando-se, em princípio, uma das hipóteses de cabimento da reclamação"49.

Com o aperfeiçoamento do sistema de controle de constitucionalidade advindo da entrada em vigor da Constituição Federal de 1988 e das Emendas Constitucionais 3/1993 e 45/2004, o tema voltou a ser destaque no debate do Supremo Tribunal Federal. Da mesma forma, com as reformas processuais que ampliaram sobremodo a eficácia de suas decisões, também o Superior Tribunal de Justiça tem sido palco de discussões a respeito dos limites do cabimento da reclamação constitucional.

Como se pode ver, o divórcio efetuado pelo Supremo entre a reclamação prevista em seu Regimento Interno e aqueloutras previstas nos Regimentos dos Tribunais de Segundo Grau propiciou o desenvolvimento de discussões relativas exclusivamente àquele primeiro tipo de reclamação. O Supremo passou a discutir questões específicas do processo de reclamação voltadas a salvaguardar sua competência e a autoridade de seus julgados, a qual já adquiria fumus de verdadeira ação, cuja constitucionalização viria logo em seguida.

\footnotetext{
${ }^{48}$ Rcl. 202/SP, rel. MINISTRO MOREIRA ALVES, j. em19.11.1986.

${ }^{49}$ Ob. cit., p. 260-261.
} 


\subsubsection{Constituição Federal de 1988: constitucionalização}

A Constituição de 1988 foi a primeira a trazer para o seu seio o instituto da reclamação, com a previsão expressa de cabimento perante o Supremo Tribunal Federal e o Superior Tribunal de Justiça para preservação da competência e garantia da autoridade dos julgados (respectivamente arts. 102, I, $l$, e 105, I, f), em franco coroamento do desenvolvimento por que vinha passando o instituto, desde sua incrustação no Regimento Interno do Supremo em $1957^{50}$.

Até 1988, então, ocorrera aquela transformação na funcionalidade da reclamação, que passou de instrumento de feição correicional $^{51}$ - utilizável por uma das partes interessadas no processo individual (subjetivo) julgado em definitivo pelo Supremo Tribunal Federal ${ }^{52}$-a verdadeiro remédio constitucional voltado à garantia das decisões do Supremo e do Superior Tribunal de Justiça, culminando, a partir da EC 45/2004, com a previsão de cabimento para garantir a observância das súmulas vinculantes (art.103-A, $\left.\S 3 .^{\circ}\right)$.

Essa constitucionalização nada mais foi que a consolidação do entendimento do STF segundo o qual a reclamação não possuía mais caráter correicional e tampouco podia fazer as vezes de recurso, ou seja, tinha nítida natureza de ação voltada ao controle do cumprimento de suas decisões e do Superior Tribunal de Justiça bem como a preservar a competência de ambos.

Com relação às duas hipóteses de cabimento, no entanto, é preciso ponderar que, na verdade, garantir a autoridade das decisões não deixa de ser uma face do respeito à

\footnotetext{
${ }^{50}$ Lembrando que o STF, julgando a RP 1092/DF, Rel. MIN. DJACI FALCÃO, declarou inconstitucional a norma do Regimento Interno do TRF que previa a reclamação, reconhecendo que só a ele, STF, foi autorizado, pela CF/67, a estabelecer regras sobre processos de sua competência (art.115, par. único, "c").

${ }^{51}$ Embora baste uma pesquisa no sítio eletrônico do STF, para se encontrarem acórdãos recentes atribuindo tons correicionais à reclamação, resquício mais da sua origem do que de sua natureza jurídica propriamente dita. V., a propósito: "A reclamação tem natureza de remédio processual correcional, de função corregedora. Ademais, o STF somente admite a reclamação nos casos de processos sem trânsito em julgado, ou seja, com recurso ainda pendente” (Rcl. 909-AgR, Rel. p/ o ac. MIN. NELSON JoBIM, j. 09/09/2004, Plenário, DJ 27/05/2005).

${ }^{52} \mathrm{O}$ Tribunal Federal de Recursos a instituiu em seu Regimento Interno, mas o STF, no julgamento da RP 1092/DF, rel. MIN. DJACI FALCÃO, decidiu pela inconstitucionalidade do dispositivo regimental, dado que só a ele, STF, foi autorizado, pela CF/67, estabelecer regras sobre processos de sua competência (art.115, par. único, "c"). Esse julgamento é um marco na definição dos contornos da reclamação para salvaguarda da competência e da garantia das decisões do Supremo (v., tb., NAVARRO DANTAS, ob. cit., p. 229-257).
} 
competência do órgão que as profere ${ }^{53}$. Noutros termos, se uma tutela jurisdicional foi prestada por quem era mesmo competente para exercitar a jurisdição no caso, qualquer ato que contrarie a eficácia promanada da decisão na qual foi estampada estará, em certa medida, interferindo de forma indevida na competência de quem a proferiu. Sobretudo isso se verifica nos casos em que o desobediente é outro órgão também dotado de competência jurisdicional; os demais casos seriam de conflito de atribuições ${ }^{54}$.

A previsão expressa no texto constitucional, no entanto, não extirpou as dúvidas com relação à natureza jurídica do instituto, que persistiram por bom tempo nos debates do STF. Por exemplo, no voto que proferiu na Ação Direta de Inconstitucionalidade 2.2121/CE, que analisava a constitucionalidade da previsão do instituto da reclamação na Constituição do Ceará, o Ministro MoreIRA Alves afirmou o seguinte:

"não se justifica a criação de um instituto como esse [reclamação], com relação a Tribunal de Justiça, por Constituição Estadual, porquanto o Juiz estadual da execução está subordinado ao Tribunal, não havendo, portanto, necessidade dessa medida excepcional, que se admite para os Tribunais que têm competência nacional com relação a decisões da Justiça Estadual Comum e da Justiça Federal"55.

Nota-se, com nitidez, no pensamento de MOREIRA AlvES, o viés hierárquico e interno da reclamação, muito ligado à sua origem correicional, na linha da "preclusão hierárquica” a que alude CÂNDIDO RANGEL DINAMARCO, ao afirmar que

"decidida a matéria em grau superior, aos órgãos jurisdicionais menos elevados não cumpre senão dar cumprimento ao decidido, seja mediante

\footnotetext{
${ }^{53}$ MONIZ DE ARAGÃo é expresso ao afirmar que, "desde que algum juiz ou tribunal amplie ou restrinja os limites de uma decisão proferida pelo Supremo Tribunal, verificar-se-á, exatamente, a hipótese de estar esse juiz, ou tribunal, exercendo ato da competência privativa do Supremo Tribunal" (A correição parcial, p. 105). Em outra passagem, o autor afirma, categoricamente, que "a reclamação revela os contornos de um incidente de competência" (p. 109).

${ }^{54}$ Desse modo, embora, à primeira vista, possa parecer que as reclamações voltadas ao respeito à sua competência não sirvam como forma de controle dos precedentes do STF e do STJ, percebe-se que não importa a hipótese constitucional em si, mas, sim, a causa de pedir do pedido reclamatório. Se esta se basear em precedente relativo à definição da competência constitucional desses órgãos, a decisão exarada na reclamação, por certo, estará a favor ou contra aquele julgamento anterior, reforçando ou rechaçando a tese nele firmada, muito embora possa se tratar de precedente meramente persuasivo. O Supremo Tribunal Federal já chegou a exercer, via reclamação, o controle difuso de constitucionalidade de Constituição Estadual (Rcl. 595/SE, Rel. Min. Sydney Sanches, Pleno, DJ de 23/05/2003). Neste caso, o Tribunal julgou procedente a reclamação, extinguiu, sem examinar o mérito, o processo de Ação Direta de Inconstitucionalidade que tramitava perante a Justiça Sergipana e declarou, incidentalmente, a inconstitucionalidade das expressões "Federal e da", presentes na alínea "c" do inciso I do art. 106 da Constituição daquele Estado, que criavam a hipótese de ADI estadual para controlar a constitucionalidade de leis ou atos normativos municipais em face da Constituição Federal, comunicando-se o Senado, nos termos do art. 52, X, da CF.

${ }^{55}$ ADI 2.212-1/CE, rel. MIN. ELLEN GRACIE, v. m., j. 02/10/2003, DJ 20/11/2003.
} 
a implantação das situações práticas determinadas, seja proferindo decisões sobre matéria subsequente ou prejudicada, de modo harmonioso com a decisão vinda do alto da hierarquia judiciária",

A propósito, vale destacar que DinAMARCO, portanto, defende a natureza jurisdicional da reclamação, por entender que sua eficácia vai além da "consistente em chamar o juiz à obediência ou de preservar o espaço constitucionalmente reservado a um desses tribunais", e que "cassar uma decisão é típica atividade jurisdicional”, sendo absurdo pensar em medidas "puramente administrativas capazes de banir a eficácia de atos de exercício da jurisdição".

Entretanto, essa forma de ver a reclamação abstrai as hipóteses em que não se trata de mero cumprimento executivo da decisão do Tribunal, mas de aplicação da norma fixada no precedente. Da mesma forma, olvida-se a hipótese de cabimento contra atos não jurisdicionais violadores de súmula vinculante, a qual tende a ser cada vez mais recorrente à medida que se criam novos verbetes ${ }^{57}$. Em outros termos, apenas quando ataca uma decisão judicial que deixa de dar cumprimento à decisão superior é possível ver esse viés quase correicional, interna corporis, baseado na hierarquia judiciária. Nos demais casos, não faz sentido algum atribuir-lhe essa marca.

O atual estágio de desenvolvimento funcional da reclamação constitucional está intimamente ligado ao movimento de valorização dos precedentes judiciais no Brasil, que traz a reboque a necessidade - a nosso ver equivocada - de previsão de um instrumento processual específico para fazer valer a força daqueles precedentes. Por essa razão, a ampliação do cabimento da reclamação está ligada à ampliação da eficácia das decisões dos tribunais superiores. Quanto mais houver decisões de caráter vinculante, maior será o campo de atuação da reclamação.

\footnotetext{
${ }^{56}$ DINAMARCO. A reclamação no processo civil brasileiro, in: Nova era do processo civil, p. 210. Segundo o autor, "essa preclusão não se acomoda nas classificações usualmente apresentadas pela doutrina, pela razão de que estas são voltadas às situações das partes e não do juiz. Reconhecido, porém, que a Constituição e os regimentos internos instituem um efeito extintivo do poder-dever deste, é imperioso reconhecer que se trata de uma preclusão, sendo essa uma preclusão hierárquica" (ob. cit., p. 211). Para HEITOR SICA, essa preclusão é uma modalidade peculiar de preclusão de questões processuais, que, segundo sua classificação, refere-se à "limitação dos poderes do juiz em reapreciar questões incidentais já resolvidas e acerca das quais não houve recurso de agravo" (Preclusão processual civil, p. 183-184 e 224).

${ }^{57}$ Nada obstante as vozes que a entendem como hipótese natimorta (José HoRÁCIO CINTRA GonÇALVES PEREIRA, Da reclamação, p. 409).
} 
Nessa toada, exemplo do alargamento do uso, este decorrente de decisão do próprio Supremo Tribunal Federal ${ }^{58}$, é o cabimento da reclamação para controle da eficácia dos acórdãos e súmulas do Superior Tribunal de Justiça perante os Juizados Especiais Estaduais, diante da ausência de mecanismo adequado de uniformização de jurisprudência nesse microssistema - assunto de que cuidaremos com detalhe mais adiante.

Como parece restar assentado, a linha evolutiva do instituto é cheia de atalhos e labirintos que a tornam de difícil simplificação. Parece inegável, contudo, que a reclamação, desde a época em que nem sequer era regulada pelo Regimento Interno do STF até os dias atuais, sempre foi um instrumento-coringa, utilizável à falta de outro ${ }^{59}$. De lá pra cá, é natural que a praxe forense passasse a ver na reclamatória um eficaz meio de atingir os mais altos degraus da hierarquia judiciária do Brasil sem passar pelas instâncias ordinárias e pelos obstáculos - cada vez maiores - dos recursos extraordinário e especial ${ }^{60}$.

Nessa linha histórica de transformações por que vem passando a reclamação, como bem reflete RICARDO DE BARROS LEONEL ${ }^{61}$, o problema virá da banalização do uso, ou seja, do abuso. Diremos, contudo, evitando qualquer nuança pejorativa, que essa hiperutilização do instrumento, a permitir que qualquer interessado bata às portas dos tribunais superiores, diretamente, sem passar por qualquer portão ou gradil das instâncias ordinárias, é resultado inescapável da sua utilização para controle de precedentes vinculantes dotados de eficácia erga omnes.

\footnotetext{
${ }^{58}$ STF, RE 571.572 ED, rel. MiN. ELLEN GRACIE, j. 26/08/2009, DJe 27/11/2009.

${ }^{59}$ Como se verá no item 4.1., recentemente, no julgamento do RE 571.572-8/BA, Rel. MIN. ELLEN GRACIE, o STF ampliou ainda mais o uso da reclamação, à falta de previsão legal de mecanismo cabível para enfrentar jurisprudência dos Juizados Especiais dissonante da estabelecida pelo STJ. Em nome da segurança jurídica e do respeito maior à unidade da aplicação da legislação federal, que, ao ver da maioria, não poderia receber tratamento diferenciado do entendimento do Superior Tribunal de Justiça, aceitou-se a utilização da reclamação prevista no artigo 105 , I, $f$, da CF, contra decisões do Juizado, reconhecendo a supremacia deste instituto em face do descabimento de recurso especial nessas hipóteses. A propósito, v. EDUARDO CAMBI e Vinícius SeCAFEn Mingati, Nova hipótese de cabimento da reclamação, protagonismo judiciário e segurança jurídica, RePro 196/295.

${ }^{60}$ Pondere-se que a própria situação hierárquica dos tribunais superiores propicia o salto de instâncias quando da utilização da reclamação, pois os órgãos de primeiro grau, incumbidos da exequibilidade das decisões superiores, é que podem, eventualmente, descumpri-las, não se podendo falar que tal descumprimento deve ser controlado em segundo grau de jurisdição.

${ }^{61}$ Diz o autor: "[...] deve ser examinado com cautela (o mecanismo da reclamação constitucional), para que eventual excesso e indevido emprego, bem como desmedida abertura quanto à sua aceitação pelo STF, não banalizem a reclamação constitucional. Isso, sob pena de um indesejável efeito perverso e colateral: o do excesso de demandas endereçadas diretamente àquela Corte [...] em momento em que o legislador vem procurando, por outros mecanismos, racionalizar sua atuação (v.g.: repercussão geral para fins de admissibilidade do recurso extraordinário; julgamento de caso-modelo nos recursos extraordinários repetitivos; decisões monocráticas proferidas pelo relator ou pelo Presidente em inúmeros casos etc.)" (ob. cit., p. 123).
} 
Em voto recente e paradigmático, o Ministro TeORI ZAVASCKI defendeu a necessidade de se colocar limites à utilização da reclamação, no que foi acompanhado pelos que votaram em seguida:

“[...] não se pode estabelecer sinonímia entre força expansiva e eficácia vinculante erga omnesa ponto de criar uma necessária relação de mútua dependência entre decisão com força expansiva e cabimento de reclamação [...] Assim, sem negar a força expansiva de uma significativa gama de decisões do Supremo Tribunal Federal, é de ser mantida a sua jurisprudência, segundo a qual, em princípio, a reclamação somente é admitida quando ajuizada por quem tenha sido parte na relação processual em que foi proferida a decisão cuja eficácia se busca preservar" ${ }^{\prime 62}$.

Essa discussão a respeito do papel da reclamação no controle da aplicação da ratio decidendi, extraível das decisões do Supremo Tribunal Federal e do Superior Tribunal de Justiça, reflete o movimento de criação de um sistema de precedentes no Brasil e convida à reflexão sobre se a reclamação é o instrumento adequado para esse fim - se é que, de fato, existe um instrumento processual adequado - ou se acabará por contrariar a própria essência do sistema de respeito a precedentes, tal como vigorante nos países do common law.

De modo indiscutivelmente correlato, impõe-se indagar se tal utilização não vai na contramão de todas as mudanças processuais das últimas décadas, voltadas ao maior aproveitamento do processo, com técnicas que ampliam a eficácia das decisões judiciais dos tribunais, permitindo, por exemplo, o julgamento de um único caso modelo, a ser aplicável aos futuros que lhe sejam idênticos, ou o julgamento monocrático pelo relator.

Na realidade, portanto, essa nova fase da reclamação nada mais é que o reflexo da pretensa ampliação do respeito aos precedentes dos tribunais constitucionais. Nos dizeres de LUIZ GUILHERME MARINONI, nessa perspectiva,

\footnotetext{
${ }^{62}$ E prossegue o Ministro: "A legitimação ativa mais ampla somente será cabível nas hipóteses expressamente previstas na Constituição ou em lei ou de atribuição de efeitos vinculantes erga omnes notadamente contra atos ofensivos a decisões tomadas em ações de controle concentrado de constitucionalidade e a súmulas vinculantes, em que se admite legitimação ativa mais ampla (CF, art. 102, § 2. ${ }^{\circ}$, e art. 103-A, caput e $\S 3 .^{\circ}$; Lei 9.882/99, art. 13, e Lei 11.419/06, art. 7. ${ }^{\circ}$ ). Por imposição do sistema e para dar sentido prático ao caráter expansivo das decisões sobre a constitucionalidade das normas tomadas pelo STF no âmbito do controle incidental, há de se considerar também essas decisões suscetíveis de controle por reclamação, quando ajuizada por entidade ou autoridade legitimada para a propositura de ação de controle concentrado (CF, art. 103)"(Rcl. 4335/AC, rel. MiN. Gilmar MendeS, j. 20/03/2014, DJe 21/10/2014).
} 
"os precedentes que definem o sentido do direito federal infraconstitucional, assim como os precedentes constitucionais, são precedentes de uma Corte Suprema. São precedentes que desenham o direito que deve orientar a sociedade e governar as decisões judiciais".

Dessarte, conclui o autor, que "o cabimento da reclamação passa a guardar relação com a autoridade das decisões da Corte enquanto precedentes constitucionais, que não podem ser desrespeitados em qualquer caso",63.

A pretensão de instituir no País um sistema de respeito ao precedente judicial tem levado a doutrina e o legislador a buscarem mecanismos (supostamente) eficazes de fazer valer a eficácia dos acórdãos do Supremo Tribunal Federal e do Superior Tribunal de Justiça para além dos processos nos quais são prolatados, o que, em tese, aumentaria a eficiência do Poder Judiciário, valorizando a segurança, a isonomia e a economia.

A presente dissertação visa a mostrar que se pode estar dando interpretação extensiva demais às hipóteses dos artigos 102, I, $l$ e 105, I, $f$, da Constituição Federal ${ }^{64}$, e que a reclamação constitucional pode não ser o instrumento adequado para atingir esses fins, em especial diante dos efeitos colaterais dessa ampliação de escopo já sentidos tanto no STJ como no STF.

\subsubsection{Direito infraconstituciomal}

Como se trata do mesmo instituto processual, ao qual a EC 45/2004 apenas agregou nova funcionalidade, natural que o regime jurídico das reclamações previstas desde a promulgação da Carta de 1988 (que vem desde a regulamentação no Regimento Interno do Supremo em 1957) seja um só, excetuadas as especificidades das quais se tratará logo mais. Interessante questão é saber se, de fato, é possível falar em um regime único, aplicável a todas as hipóteses hoje previstas no texto constitucional.

Como já antevisto, a reclamação, que sempre foi regulada pela própria jurisprudência do Supremo, apenas em 1957, com espeque no artigo 97, II, da CF/1946, veio a ter o primeiro locus de regulamentação: o TítuloII, CapítuloV, “A”, do Regimento Interno daquele Tribunal. Desde então, o que ali se escreveu ali permaneceu intacto, mesmo depois

\footnotetext{
${ }^{63}$ O STJ enquanto Corte de precedentes, p. 242.

${ }^{64}$ A propósito, o fruto dessa interpretação ampliativa do cabimento da reclamação encontra-se, desde 2004, no artigo 103-A, §3..$^{\circ}$ da Constituição, que a institucionalizou como mecanismo de controle de aplicação das súmulas vinculantes.
} 
de os artigos 102, I, $l$, e 105, I, $f$, da Constituição Federal de 1988 preverem, expressamente, a reclamação como remédio cabível para preservar a competência do STF e do STJ e garantir a autoridade das suas decisões.

Na verdade, somente em 1990, com o advento da Lei Federal $8.038^{65}$, a reclamação constitucional passou a ter, por assim dizer, legalizado seu procedimento, ainda que muito minguadamente. Dado o caráter de ação constitucional, embora alguns entendam desnecessário, parece-nos no mínimo que era recomendável a regulamentação vir prevista em lei. A nova lei veio, portanto, em boa hora.

Os dispositivos consolidam velha jurisprudência do STF a respeito do tema, desenhando um procedimento muito semelhante ao do mandado de segurança. Com efeito, a reclamação há de ser instruída com prova documental e será enviada ao relator da causa principal sempre que possível, o qual requisitará informações à autoridade reclamada, que as prestará em 10 dias. Há previsão expressa de suspensão liminar do processo ou do ato impugnado para evitar dano irreparável, desde que preenchido, também, o requisito da judicialidade, ou seja, haja fumus boni iuris pairando sobre a alegação de violação da decisão paradigma.

A respeito, aliás, calha mencionar que, historicamente, a primeira vez em que o Supremo Tribunal Federal analisou a viabilidade de admitir liminar cautelar em sede de reclamação se deu em 1985, ao julgar a RclMC 195/AM, rel. MiNISTRO NÉRI DA SILVEIRA. E o fez para deferir a concessão da medida, sem maiores debates.

Trata-se, em verdade, de decorrência lógica do reconhecimento de sua natureza jurisdicional, pois a tutela jurisdicional, para ser efetiva, às vezes carece de urgência, ou seja, a possibilidade de concessão de liminares, tenham elas natureza cautelar ou antecipatória da tutela final, está intrinsecamente ligada à efetividade do próprio direito de ação. Nesse ponto, tanto faz reconhecermos na reclamação constitucional uma ação ou um

\footnotetext{
65 "Art. 13. Para preservar a competência do Tribunal ou garantir a autoridade das suas decisões, caberá reclamação da parte interessada ou do Ministério Público. Parágrafo único. A reclamação, dirigida ao Presidente do Tribunal, instruída com prova documental, será autuada e distribuída ao relator da causa principal, sempre que possível. Art. 14. Ao despachar a reclamação, o relator: I - requisitará informações da autoridade a quem for imputada a prática do ato impugnado, que as prestará no prazo de dez dias; II ordenará, se necessário, para evitar dano irreparável, a suspensão do processo ou do ato impugnado. Art. 15. Qualquer interessado poderá impugnar o pedido do reclamante. Art. 16. O Ministério Público, nas reclamações que não houver formulado, terá vista do processo, por cinco dias, após o decurso do prazo para informações. Art. 17. Julgando procedente a reclamação, o Tribunal cassará a decisão exorbitante de seu julgado ou determinará medida adequada à preservação de sua competência. Art. 18. O Presidente determinará o imediato cumprimento da decisão, lavrando-se o acórdão posteriormente."
} 
recurso, pois este se conceitua justamente como sendo uma consequência natural do exercício do direito de ação.

Contudo, não faz sentido que apenas danos irreparáveis causados por atos comissivos sejam protegidos pela norma. Evidente, portanto, que a liminar poderá consistir em uma determinação para que o órgão reclamado aja de acordo com a decisão paradigma violada. No mesmo sentido, se pronunciou José Horácio CinTRA GonçAlves PereIRA, para quem o relator poderá "não só suspender o ato impugnado ou o processo como também poderá atribuir 'efeito positivo' ou, mais corretamente, antecipar os efeitos do julgamento da reclamação para evitar igualmente dano irreparável" ${ }^{66}$.Traga-se, ainda, o artigo158 do RISTF, que permite ao relator determinar tanto a suspensão do curso do processo em que se tenha verificado o ato reclamado como a remessa dos respectivos autos ao Tribunal, em flagrante referência às duas hipóteses constitucionais da reclamação.

$\mathrm{O}$ artigo 15 permite que "qualquer interessado" possa impugnar o pedido do reclamante, mas parece evidente que esse interesse está ligado à causa em que foi proferida a decisão violadora do paradigma. Ainda com relação à participação de terceiros, o artigo 16 determina que o Ministério Público, nas reclamações que não formulou, tenha vista pelo prazo de 5 (cinco) dias.

A procedência da reclamação importará a cassação da decisão exorbitante do paradigma ou determinará a medida adequada para a preservação da competência, nos casos em que tiver sido usurpada. Nítido, portanto, o viés desconstitutivo da tutela jurisdicional propiciada pelo julgamento da reclamação. Verifica-se que a lei cuida do tema partindo da premissa de ser impossível atacar ato administrativo por reclamação.

Em suma, apesar de mencionada lei pouco ter acrescentado ao que já vinha sendo aplicado com base nas normas regimentais, é ali que se encontra traçado o procedimento da reclamação perante o STF e o STJ.

Posteriormente, a Lei Federal 9.882/1999, ao disciplinar o processo da arguição de descumprimento de preceito fundamental, formalizou o que, na prática, poderia ser aceito pelo Supremo a partir de uma interpretação lógico-sistemática do artigo 102 , I, $l$, da $\mathrm{CF} / 1988$. Essa lei previu, no artigo 13, o cabimento da reclamação contra o descumprimento da decisão proferida pelo Supremo Tribunal Federal em sede de arguição

${ }^{66}$ Da reclamação, p. 406. 
de descumprimento de preceito fundamental (ADPF), na forma do seu Regimento Interno, ou seja, sob o regime geral das reclamações.

Finalizando o sistema processual e procedimental relativo à reclamação constitucional, mais recentemente a EC45, de dezembro de 2004, acrescentou o artigo 103A à CF/1988, tratando das "súmulas vinculantes", cujo regime foi estabelecido pela Lei Federal 11.417/2006, a qual, com muita parcimônia, dedicou à disciplina do instituto apenas o artigo $7 .^{067}$.

Da comparação entre os dois diplomas legais, a única distinção considerável se deve à inclusão da possibilidade de atacar ato administrativo via reclamação, bem como as normas específicas aplicáveis a essa hipótese, como é o caso do $§ 1 .^{\circ}$ do artigo $7 .^{\circ}$, que estabelece o esgotamento da instância administrativa como condição para a utilização da reclamação.

A propósito, como MARCELo Ribeiro DANTAS ${ }^{68}$, entendemos que o artigo $7 .^{\circ}, \S 1 .^{\circ}$, da Lei 11.417/2006, encerra uma manifesta limitação inconstitucional ao uso da reclamação, ao interpor a condição de esgotamento das vias administrativas, restrição esta que não há no artigo 103-A, $\S 3 .^{\circ}$, da Carta Magna, e tampouco se justifica por critérios de proporcionalidade $^{69}$.

\footnotetext{
67 “Art. 7. ${ }^{\circ}$ Da decisão judicial ou do ato administrativo que contrariar enunciado de súmula vinculante, negar-lhe vigência ou aplicá-lo indevidamente caberá reclamação ao Supremo Tribunal Federal, sem prejuízo dos recursos ou outros meios admissíveis de impugnação. $\S 1 .{ }^{\circ}$ Contra omissão ou ato da administração pública, o uso da reclamação só será admitido após esgotamento das vias administrativas. § $2^{\circ}$ Ao julgar procedente a reclamação, o Supremo Tribunal Federal anulará o ato administrativo ou cassará a decisão judicial impugnada, determinando que outra seja proferida com ou sem aplicação da súmula, conforme o caso."

${ }^{68}$ Para o autor, o dispositivo é um atraso, e sua inconstitucionalidade é, "por qualquer ângulo", patente, pois "seja qual for a natureza jurídica que se entender tenha a reclamação, induvidoso é que se constitui medida estabelecida pela Constituição sem a condição que o legislador ordinário indevidamente agora tenta lhe impor" (Novidades em reclamação constitucional: seu uso para impor o cumprimento de súmula vinculante, in: MedinA, José Miguel Gargia et al. (coord.). Os poderes do juiz e o controle das decisões judiciais:estudos em homenagem à professora Teresa Arruda Alvim Wambier,p. 1186).

${ }^{69} \mathrm{Em}$ sentido diverso:,Curso sistematizado de direito processual civil, v. V, p. 425. O autor afirma que a exigência é correta "CASSIO SCARPINELLA BUENO e não viola o 'modelo constitucional do direito processual civil' porque impõe à Administração Pública que se comporte de maneira eficiente, como lhe determina o caput do art. 37 da Constituição Federal, manifestando-se em conformidade com as súmulas vinculantes do Supremo Tribunal Federal". Entretanto, antes de respeitar o princípio da eficiência, a Administração pública é escrava da lei e, por conseguinte, das decisões judiciais com "força de lei". Além do mais, a exigência de prévia instauração de processo administrativo (ou esgotamento dessas vias), a par de vir limitar uma garantia constitucional sem qualquer razão justificável, a nosso ver, em nada é capaz de tornar a Administração mais eficiente ou mais obediente à lei. Também em sentido contrário ao do texto: SANDRO MARCELO KOZIKOSKI, "As súmulas vinculantes na esteira da Lei 11.417/2006", in: MEDINA, José Miguel Gargia et al. (coord.). Os
} 
Se a ideia do constituinte era encurtar o árduo caminho ${ }^{70}$ que levaria o sujeito que teve seu direito violado em razão da inobservância de súmula vinculante a perambular por todas as instâncias até chegar, via recurso, ao Supremo Tribunal Federal, não parece razoável aceitar que, quando se tratar de ato administrativo (ou de omissão da Administração), o reclamante deva primeiro se submeter a um procedimento não jurisdicional.

Por outro lado, entretanto, elogiável a reforma feita pela Lei 11.417/2006 na Lei 9.784/1999, que regula o processo administrativo no âmbito da Administração Pública Federal, para incluir disposição expressa, no artigo $56, \S 3 .^{\circ}$, para que a autoridade administrativa, caso o recurso traga impugnação fundada em contrariedade a verbete vinculante, se não reconsiderar a decisão, explicite "as razões da aplicabilidade ou inaplicabilidade da súmula" antes de encaminhar o recurso à autoridade superior, à qual também incumbe o mesmo dever, nos termos do artigo 64-A.

A lei passou, também, a contar com o artigo $64-\mathrm{B}^{71}$, reforçando ainda mais a obrigatoriedade de cumprimento das súmulas vinculantes, deixando evidente conclusão sobre a qual não deveriam pairar quaisquer dúvidas ${ }^{72}$. Hoje, todo reforço é bem-vindo no sentido da devida e constitucional motivação das decisões estatais, por mais redundante e desnecessário que possa ser, diante da claridade do disposto no artigo 93, IX, da CF/1988.

O regime também foi inovado com a previsão do artigo $7 .^{\circ}$, caput, de que caberá reclamação, "sem prejuízo dos recursos ou outros meios admissíveis de impugnação". Talvez o legislador, temeroso da avalanche de reclamações que poderiam ser ajuizadas, quis deixar mais claro o que já era evidente: ao lado da reclamação, de competência

poderes do juiz e o controle das decisões judiciais: estudos em homenagem à professora Teresa Arruda Alvim Wambier,p. 1207.

${ }^{70}$ No dizer de DINAMARCO: "A técnica da reclamação ao Supremo Tribunal Federal tem a grande vantagem de permitir a queima de etapas, podendo o interessado ir diretamente ao órgão máximo do Poder Judiciário, sem ter de passar pelos diversos graus jurisdicionais mediante sucessivos recursos" (Súmulas vinculantes, in Fundamentos do processo civil moderno, 6. ed., tomo I, p.236).

${ }^{71 “}$ Art. 64-B. Acolhida pelo Supremo Tribunal Federal a reclamação fundada em violação de enunciado da súmula vinculante, dar-se-á ciência à autoridade prolatora e ao órgão competente para o julgamento do recurso, que deverão adequar as futuras decisões administrativas em casos semelhantes, sob pena de responsabilização pessoal nas esferas cível, administrativa e penal.”

${ }^{72}$ Não temos o receio de MARCELO DANTAS, segundo quem, se a autoridade administrativa justificar por que entende não aplicável o verbete sumular, "o prejudicado vai ficar sem poder ingressar com a reclamação" (Novidades em reclamação constitucional: seu uso para impor o cumprimento de súmula vinculante, p. 1186). Pensamos que, de acordo com o script legal, a decisão fundamentada da Administração, ao contrário, servirá para embasar a reclamação e levará, já com a inicial, os argumentos da autoridade reclamada ao conhecimento do relator no STF. 
exclusiva do STF, todos os demais meios e técnicas existentes no sistema podem ser utilizados. Essa utilização, contudo, pressupõe o preenchimento dos requisitos próprios de cada instrumento. Por exemplo, somente poderá recorrer de uma decisão que aplicar indevidamente a súmula vinculante aquele que tiver sucumbido no processo, ou seja, ainda que se esteja diante de uma decisão violadora do comando sumular, para questioná-lo no processo via recurso, será preciso demonstrar o devido interesse recursal.

Resta a pergunta a ser respondida pela jurisprudência do Supremo: a partir da Lei 11.417/2006caberá reclamação contra ato administrativo apenas quando se estiver em confronto com súmula vinculante? Embora o Tribunal já tenha aventado tal possibilidade em alguns julgados, a grande massa de reclamações ajuizadas com fulcro no artigo 102, I, $l$, da CF, por incrível que possa parecer, ataca ato jurisdicional. A nosso ver, será impossível defender qualquer tipo de restrição, ou seja, o regime será um só.

Por fim, enquanto o artigo 13 da Lei 8.038/1990 é expresso ao afirmar que a reclamação "será instruída com prova documental”, a Lei 11.417/2006é silente a respeito. Legítimo ou não, sem qualquer reflexão, o STF vem aplicando a norma restritiva da lei antiga às reclamações fundadas na lei nova. Embora a tendência histórica seja tratar tudo quanto for chamado de reclamação da mesma forma, pensamos que, aqui, esteja uma boa oportunidade para se ponderar a respeito da técnica adequada à nova funcionalidade do instrumento.

Com relação à disciplina regimental da reclamação, é preciso dizer que as normas regimentais pouco inovam, valendo mencionar a possibilidade de o relator julgar monocraticamente a reclamação quando a matéria for objeto de jurisprudência consolidada do STF (art. 161, parágrafo único, do RISTF). Por seu turno, o Regimento interno do STF nada traz de diferente do que já está previsto na lei. 


\subsubsection{Reclamação no novo Código de Processo Civil $^{73}$}

Seguindo a onda de valorização de precedentes, que, consequentemente, tem visto na reclamação o mecanismo adequado de controlar a sua aplicação, o projeto de novo Código de Processo Civil inova ao disciplinar a reclamação, generalizando seu cabimento, de forma, a nosso ver, temerária e despreocupada com as consequências da banalização. De todo modo, o fato é que, aprovado e sancionado o projeto tal como está, a reclamação se tornará o instrumento ordinário de controle da aplicação de precedentes.

Faremos, aqui, uma breve análise dos dispositivos constantes do último texto disponível antes da aprovação pelo Senado, pois no Capítulo 3 voltaremos a essas hipóteses.

Na última versão do novo Código de Processo Civil disponível no sítio eletrônico do Senado, a reclamação vem regulada nos artigos 985 a 990 do Capítulo XIX do Título I ("Da Ordem dos Processos e dos Processos de Competência Originária dos Tribunais") do Livro III(“Dos Processos nos Tribunais e Dos Meios de Impugnação das Decisões Judiciais").

O artigo 985 prevê as hipóteses de cabimento da ação reclamatória, a ser apresentada pela parte interessada ou pelo Ministério Público. São elas: I - preservar a competência do tribunal; II - garantir a autoridade das decisões do tribunal; III - garantir a observância de decisão do Supremo Tribunal Federal em controle concentrado de constitucionalidade; IV

\footnotetext{
${ }^{73}$ Referimo-nos ao texto final aprovado pela Comissão Temporária do Senado (votação dia 04/12/2014), relativo ao Projeto de Lei 8.046/2010, oriundo da Câmara dos Deputados, em revisão ao PLS 166/2010. A propósito da tramitação do novo CPC, consta do Relatório do Senador Vital do Rêgo: "O Senado Federal aprovou, em 15/12/2010, o Projeto de Lei do Senado (PLS) n. 166, de 2010, que pretende criar o novo Código de Processo Civil. Enviada à revisão da Câmara dos Deputados em 20/12/2010, a proposição passou a tramitar como Projeto de Lei (PL) n. 8.046, de 2010. Tendo sido aprovada naquela Casa com substitutivo, a matéria retornou ao Senado Federal em 1.\%/2014, em obediência ao disposto no art. 65, parágrafo único, da Constituição Federal, segundo o qual o projeto de lei aprovado por uma Casa será revisto pela outra e, sendo emendado, voltará à Casa iniciadora". Lembra, ainda, referido relatório, que o Senado apenas poderá aprovar as emendas vindas da Câmara, rejeitá-las, revigorando o texto primitivo do Senado, ou promover emendas de redação, assim entendidos os ajustes de redação que expurguem do texto final inconsistências lógicas, gramaticais ou de técnica legislativa, sem ineditismos no conteúdo normativo. Dosponível em: <http://www12.senado.gov.br/noticias/materias/2014/11/27/novo-codigo-de-processo-civil-comissao-votasugestoes-dos-deputados-no-dia-4>.Acesso em: 26 dez. 2014). Até a impressão desse trabalho, não estava disponível o texto final aprovado pelo Senado.
} 
- garantir a observância de súmula vinculante ${ }^{74}$ e de precedente proferido em julgamento de casos repetitivos ou em incidente de assunção de competência ${ }^{75}$.

Primeiro, é preciso dizer que o texto proposto pela comissão temporária do Senado vem corrigir certas imperfeições vindas da Câmara. Com efeito, tendo em conta as disposições relativas aos precedentes judiciais (arts. 924 a 926 do Projeto), não se encontrava justificativa mesmo para a diferenciação feita pelos incisos III e IV $^{76}$ do artigo 1000 do texto vindo da Câmara entre decisão, acórdão e precedente; sobretudo porque os artigos 201 e 202 do Projeto mantêm a divisão dos pronunciamentos judiciais entre despachos, decisões interlocutórias, sentenças e acórdãos, e o Código não define o que seja precedente.

Até seria compreensível uma distinção entre verbetes de súmula e precedentes, como será exposto abaixo, mas, como estava, o texto elencava dois conceitos que se relacionam pela marca da continência, ou seja, acórdãos e decisões são conceitos contidos no conceito de precedente, que os abarca com facilidade. Portanto, de duas uma: ou o Código deveria definir o que é precedente, em diferenciação de acórdão e decisão - o que seria difícil -, ou usar apenas um dos dois termos, sendo melhor usar apenas o termo "precedente", abarcando aí os acórdãos e eventualmente alguma sentença ou decisão que venha a adquirir fumos de precedente. Todavia, a comissão do Senado optou por "decisão" no inciso III e "precedente" no inciso IV. Permanece a confusão conceitual.

O texto, sem esclarecer as razões, também utiliza termos diferentes ao prever o objeto da reclamação, ou seja, o que seu pedido visa a garantir; referimo-nos ao uso de "garantir a autoridade" no inciso II e "garantir a observância" nos incisos III e IV. A única distinção que pode ser suposta diz respeito à eficácia das decisões tratadas nos incisos III e

\footnotetext{
${ }^{74}$ Essa hipótese, que é disciplinada pela Lei Federal 11.417/06, será melhor tratada em item próprio.

$75 \mathrm{O}$ artigo 944 do novo Código estabelece que é "admissível a assunção de competência quando o julgamento de recurso, da remessa necessária ou de causa de competência originária envolver relevante questão de direito, com grande repercussão social, sem repetição em múltiplos processos”. Forçoso verificar, da leitura do dispositivo, que o problema que afeta o artigo $555, \S 1 .^{\circ}$, do atual Código remanescerá, ou seja, o julgamento da questão jurídica pelo órgão responsável pela uniformização da jurisprudência do respectivo tribunal continuará a depender do subjetivismo do relator em reconhecer os requisitos da relevância e da grande repercussão social, a indicar uma potencial multiplicação de demandas. Na prática, então, o uso desse mecanismo de uniformização tende a continuar raríssimo, pois o órgão competente para o julgamento do incidente só conhece dele após a análise do relator do caso concreto.

${ }^{76} \mathrm{O}$ texto veio assim da Câmara dos Deputados: "III - garantir a observância de decisão ou precedente do Supremo Tribunal Federal em controle concentrado de constitucionalidade; IV - garantir a observância de súmula vinculante e de acórdão ou precedente proferido em julgamento de casos repetitivos ou em incidente de assunção de competência" (destacamos).
} 
IV, que preveem hipóteses de decisões com nítida eficácia vinculante, ou seja, o que ali estiver fixado obriga a todos, além das partes litigantes. Como se verá no Capítulo 3, nesses casos, estamos diante de verdadeiros precedentes vinculantes. Com essa premissa, o inciso II fica reservado às hipóteses que hoje já vêm previstas nos Regimentos Internos, ou seja, aquelas em que a reclamação é utilizada para fazer valer a eficácia inerente a toda decisão judicial, que deve ser cumprida pelos órgãos judiciais inferiores, responsáveis - em regra - por dar efetividade concreta às decisões superiores.

Do mesmo modo, se o próprio Código projetado estabelece a distinção entre despacho, decisão interlocutória, sentença e acórdão, não trazendo outro tipo de provimento judicial, por que utilizar o termo decisão no inciso III? Trata-se de conceito plurívoco, que pode significar "decisão interlocutória", “decisão monocrática" ou, ainda, “decisão lato sensu”, abarcando qualquer provimento judicial com conteúdo decisório ${ }^{77}$. Poder-se-ia ter utilizado apenas precedente do STF em sede de controle concentrado, o que abarcaria até as decisões liminares cautelares proferidas pelo relator e ainda não referendadas pelo Plenário; ou, ainda, “decisões com eficácia vinculante proferidas em controle concentrado de constitucionalidade".

É preciso mencionar, também, no tocante ao inciso IV, que o julgamento de casos repetitivos diz respeito a precedentes proferidos em recursos especiais e extraordinários repetitivos e incidentes de resolução de demandas repetitivas, nos termos do artigo 926 da versão aqui tratada ${ }^{78}$, que esclarece o que vêm a ser "casos repetitivos" para fins da vinculação pretendida pelo artigo 925, o qual cria uma vinculação obrigatória dos precedentes ali elencados ${ }^{79}$. Todavia, as decisões proferidas em sede de incidente de resolução de demandas repetitivas abrem ensejo a dois tipos de reclamação, segundo se

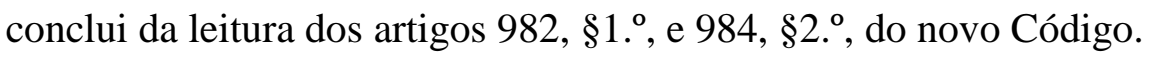

\footnotetext{
${ }^{77}$ Pode-se cogitar de o projetista ter feito alusão ao $\$ 1 .^{\circ}$ do artigo 486, que explicita o conceito de decisão judicial ao prever que "não se considera fundamentada qualquer decisão judicial, seja ela interlocutória, sentença ou acórdão": V - se limitar a invocar precedente ou enunciado de súmula, sem identificar seus fundamentos determinantes nem demonstrar que o caso sob julgamento se ajusta àqueles fundamentos; VI deixar de seguir enunciado de súmula, jurisprudência ou precedente invocado pela parte, sem demonstrar a existência de distinção no caso em julgamento ou a superação do entendimento.

${ }^{78}$ Eis o texto: “Art. 926. Para os fins deste Código, considera-se julgamento de casos repetitivos a decisão proferida em: I - incidente de resolução de demandas repetitivas; II - recursos especial e extraordinário repetitivos. Parágrafo único. O julgamento de casos repetitivos tem por objeto questão de direito material ou processual."

${ }^{79}$ A ideia parece ser de uma vinculação não apenas vertical (hierárquica, portanto), mas também horizontal, pois prevê que decisões tomadas pelo plenário ou pelo órgão especial deverão ser seguidas pelo respectivo tribunal (art. 925, V). Voltaremos ao tema no próximo Capítulo, ao tratarmos dos precedentes no Brasil.
} 
O artigo 982 afirma que, julgado o incidente, a tese jurídica será aplicada a todos os processos individuais ou coletivos que versem sobre idêntica questão de direito e que tramitem na área de jurisdição do respectivo tribunal, incluindo os processos que tramitem nos juizados especiais do respectivo estado ou região (inc. I), mas também a todos os casos futuros que versem idêntica questão de direito e que venham a tramitar no território de competência do tribunal (inc. II). O $\S 1$. odesse artigo giza que, "não observada a tese adotada no incidente, caberá reclamação" $"$.

Cuida-se, nessa primeira hipótese, portanto, de reclamação a ser ajuizada perante o tribunal a que estiver vinculado o órgão que não observar a tese fixada no incidente, valendo ressaltar que a lei nem sequer exige o trânsito em julgado da decisão, contentandose com o mero julgamento, nada obstante preveja que os recursos especial e extraordinário eventualmente interpostos serão dotados de efeito suspensivo ex vi legis, presumindo-se, também, a repercussão geral (art. 984, $\$ 1^{\circ}{ }^{\circ}$ ).

Mas haverá outra hipótese de reclamação relacionada à tese fixada no incidente, pois o §2..$^{\circ}$ do artigo 984 estabelece que, julgado o mérito dos recursos especial ou extraordinário, a tese jurídica adotada pelo STJ e pelo STF “será aplicada no território nacional a todos os processos individuais ou coletivos que versem sobre idêntica questão de direito".

Em suma, enquanto a tese não for definida pelo STJ e pelo STF, cada tribunal será responsável por julgar as reclamações de acordo com os paradigmas que fixou; içada a questão à competência dos tribunais superiores via recurso especial ou extraordinário, uma vez decidida, passa a ser obrigatória sua adoção por todos os órgãos jurisdicionais do País, e as reclamações serão decididas por essas Cortes Superiores.

O $33^{\circ}$ do mencionado artigo 985 procura adaptar a regra já existente na Lei Federal $11.417 / 2006^{81}$, ao prever que "as hipóteses dos incisos III e IV compreendem a aplicação indevida da tese jurídica e sua não-aplicação aos casos que a ela correspondam". A nosso ver, bastaria dizer: "compreendem a negativa de aplicação da tese jurídica ou sua aplicação indevida".

\footnotetext{
${ }^{80}$ Por curiosidade, vale notar que o dispositivo utiliza o verbo "observar", em um raro e feliz paralelo com a palavra "observância", utilizada nos incisos III e IV do artigo 985.

${ }^{81}$ Lei 11.417/2006: “Art. 7. ${ }^{\circ}$ Da decisão judicial ou do ato administrativo que contrariar enunciado de súmula vinculante, negar-lhe vigência ou aplicá-lo indevidamente caberá reclamação ao Supremo Tribunal Federal, sem prejuízo dos recursos ou outros meios admissíveis de impugnação".
} 
A redação do $§ 1 .^{\circ}$ também é problemática. Diz o dispositivo que "a reclamação pode ser proposta perante qualquer tribunal e seu julgamento compete ao órgão jurisdicional cuja competência se busca preservar ou autoridade se pretenda garantir”. O que o projeto parece querer dizer é o seguinte: a reclamação é cabível para preservar a competência e garantir a autoridade de decisão de qualquer Tribunal.

Por sua vez, o $\$ 2 .^{\circ}$ do artigo 985 estabelece que "a reclamação deverá ser instruída com prova documental e dirigida ao presidente do tribunal; assim que recebida, será autuada e distribuída ao relator da causa principal, sempre que possível”. Apesar de ser de difícil compreensão a limitação final do dispositivo, não é assim que ocorre hoje no STF e no STJ. Nem poderia ser diferente. Ressalvadas as hipóteses em que a reclamação visa a garantir a executividade da decisão descumprida, considerando a inerente limitação de sujeitos legítimos para ajuizá-la, nos demais casos, objeto desse estudo, atribuir essa competência ao relator da causa principal é, mais uma vez, confundir as funcionalidades do instituto.

Se a ideia é utilizar a reclamação como mecanismo de controle da aplicação dos precedentes, ou seja, das teses jurídicas fixadas nas decisões, é preciso tratar tais modelos normativos como se tratam, processualmente, os textos legais. Em termos de racionalidade da máquina judiciária, a prevenção do relator só se explica nos casos de cumprimento da decisão (executividade), não de observância da tese (normatividade), justamente porque é intrínseco a um sistema de precedentes que todos sejam capazes de confrontar as teses jurídicas postas no processo, por mais que se preveja a competência do Tribunal de onde promanou o precedente paradigma.

Os últimos dois parágrafos do artigo sacramentam a jurisprudência do Supremo Tribunal Federal, ao preverem que não cabe reclamação após o trânsito em julgado da decisão reclamada ${ }^{82}$ e a não prejudicialidade entre a reclamação e o destino de eventual recurso também interposto contra a decisão reclamada ${ }^{83}$.

\footnotetext{
${ }^{82}$ É o que consta da súmula 734 do STF: "NÃO CABE RECLAMAÇÃO QUANDO JÁ HOUVER TRANSITADO EM JULGADO O ATO JUDICIAL QUE SE ALEGA TENHA DESRESPEITADO DECISÃO DO SUPREMO TRIBUNAL FEDERAL". Tal regra, contudo, não se aplica quando se trata de ato, que embora proferido por órgão do Poder Judiciário, possua natureza administrativa, como é o caso das decisões que determinam o sequestro de verbas públicas para pagamento de precatórios (Rcl. 3207 AgR/SP, rel. Min. DiAs TOFFOLI, decisão monocrática, j. 15/02/2013, DJe 19/02/2013).

${ }^{83}$ Interessante notar que o STF parece entender que o trânsito em julgado ocorrido depois da propositura da reclamação não redunda em sua extinção, pois não se aplica a súmula 734. Veja-se: "Embargos de declaração
} 
Em síntese, o novo Código de Processo Civil generalizará as hipóteses de reclamação previstas na Constituição Federal, de modo que até naqueles Tribunais que não a têm prevista em seus Regimentos Internos será cabível seu uso para preservação da respectiva competência e garantia da autoridade de suas decisões (art. 985, I, II e III). Além dessa generalização, o Código inova ao prever o cabimento da reclamação para garantir a observância de precedente proferido em julgamento de casos repetitivos ou em incidente de assunção de competência (art. 985, IV) ${ }^{84}$. Por fim, registre-se que ficaram de fora dessa regulamentação, contudo, as hipóteses em que o ato reclamado não possui natureza jurisdicional.

Isso significa dizer que a reclamação deixou de ser constitucional para se tornar cabível de forma geral perante todo e qualquer Tribunal do País, independentemente de previsão regimental. Essa inovação acaba por tornar a discussão sobre a natureza jurídica da reclamação ainda mais insossa, já que a nova ordem legal a coloca, expressamente, entre os meios de impugnação das decisões judiciais, classificação de amplitude reconhecida.

\subsection{Natureza jurídica}

Embora se possa cogitar de não existir, no âmbito do direito processual brasileiro, instituto cuja natureza jurídica seja tão controvertida e venha sendo tão debatida como a

em reclamação. 2. Decisão monocrática. Embargos de declaração recebidos como agravo regimental. 3. Alegação de ausência de provas. Inconsistência. 4. Súmula 734. Inaplicabilidade ao caso. Trânsito em julgado posterior ao ajuizamento da reclamação. 5. Agravo regimental a que se nega provimento" (STF, Emb. Decl. na Rcl. 10.272/MA, Plenário, rel. MiN. GILMAR MENDES, j. 08/06/2011). Em caso mais antigo, o Tribunal esposou a tese de que, nessas circunstâncias, a decisão que vier a ser tomada na reclamação será capaz de anular todos os atos do processo, incluindo o trânsito em julgado: "I. Reclamação: subsistência à coisa julgada formada na sua pendência. Ajuizada a reclamação antes do trânsito em julgado da decisão reclamada, e não suspenso liminarmente o processo principal, a eficácia de tudo quanto nele se decidir ulteriormente, incluído o eventual trânsito em julgado do provimento que se tacha de contrário à autoridade de acórdão do STF, será desconstituído pela procedência da reclamação (Rcl. 509/MG, rel. MIN. SEPÚLVEDA PERTENCE, j. 17/12/1999, DJe 04/08/2000). No mesmo sentido, mais recentemente: Rcls. 3288/RJ e 2280/RJ, rel. Min. Joaquim Barbosa; Rcls. 2337-AgR/MS e 904-AgR/SC, e Rcl. 8934 ED/PE, j. 1. \%/12/2011, Dje 31/01/2012, todos da relatoria do MIN. RICARDO LEWANDOWSKI).

${ }^{84}$ Como se verá logo mais, a diferença entre a cláusula geral do inciso II (“autoridade das decisões") e as hipóteses dos incisos III e IV tem a ver com a eficácia das decisões que estão sendo, por assim dizer, garantidas. Somente a compreensão de que o inciso II trata de casos nos quais a solução dada na decisão garantida não tem o condão de se tornar modelo para outros casos, ou melhor, dela não se retira uma tese cuja aplicação é obrigatória para todos os casos idênticos, é que justifica a distinção e torna necessários os incisos III e IV. Estes, sim, relacionados à garantia de obediência a precedentes. 
reclamação, a verdade é que esse debate tem pouco ou nenhum sentido prático ${ }^{85}$, em especial depois de sua constitucionalização e da legalização de seu procedimento, notadamente, como afirmado acima, a partir da entrada em vigor do novo Código de Processo Civil, caso seja sancionado o texto que foi aprovado pelo Senado.

Isso porque o debate em torno da natureza jurídica nasceu para fundamentar as correntes que negavam ou afirmavam a legitimidade do instrumento na sua missão de cassar decisões judiciais, já que, para isso, sempre existiram os recursos. Antes de sua inserção no Regimento Interno do STF, legitimava-se seu uso a partir de sua natureza correicional $^{86}$, lembrando que não se cogitava a hipótese de atacar atos que não fossem judiciais. Tratava-se, assim, de uma extensão do poder correicional dos órgãos superiores $^{87}$.

De lá pra cá, muito da dificuldade da doutrina em encontrar um lugar dogmático próprio para a reclamação está no esquecimento de sua origem e na falsa premissa de que as correições parciais eram simples instrumentos de controle administrativo-disciplinar, quando sempre tiveram um viés recursal, destinado à correção de errores in

\footnotetext{
${ }^{85}$ Antes mesmo de ter sido constitucionalizada em 1988, a reclamação já era objeto de calorosas discussões entre os ministros do Supremo. Essa afirmação foi feita pioneiramente por ARRUDA ALVIM em 1973 (Correição parcial, p. 11). A reclamação, nos moldes como a maior parte da doutrina a concebe hoje, ou seja, como verdadeira ação constitucional - para garantia da autoridade das decisões do STF e do STJ, para a preservação da competência desses tribunais, bem como para controlar a aplicação das súmulas vinculantes do Supremo -, parece não encontrar parelha em nenhum sistema jurídico no qual se possa espelhar o direito brasileiro.Com licença da metáfora, trata-se de uma verdadeira jabuticaba jurídica: só existe no Brasil. Nesse sentido, MARCELO RIBEIRO DANTAS, após vasto estudo do direito alienígena (Reclamação constitucional no direito brasileiro, p. 385 e ss.); LEONARDO MORATO (Reclamação e sua aplicação para o respeito da súmula vinculante, p. 37); RICARDO DE BARROS LEONEL (Reclamação constitucional, p. 111).

${ }^{86}$ Todavia, não se pode perder de vista que, na origem, a correição parcial nunca teve função unicamente correicional ou administrativo-disciplinar, fazendo as vezes de verdadeiro recurso; esse fato contribuiu para turvar os olhos de quem pretendia descobrir a natureza da reclamação. Além disso, não se pode ignorar que, olhados a fundo, a hierarquia judiciária se justifica pela existência de recursos, e o controle disciplinar, embora tenha contornos e natureza próprios, possui grandes áreas intersecção de difícil encaixe em uma ou em outra categoria.

${ }^{87}$ Por isso mesmo, ainda hoje se tem dificuldade de desvincular a reclamação da correição parcial do ponto de vista de serem, ambas, instrumentos voltados a colocar ordem no processo, pois é indiscutível que "fazer valer uma decisão" ou "resguardar a competência" de uma Corte ou de um juízo qualquer é trazer o processo para o prumo, ou seja, é regularizar o devido processo legal. Questão interessante, e já aventada por DINAMARCO, é saber como ficou esse poder correicional dos Tribunais após a criação, também pela EC 45/04, do Conselho Nacional de Justiça, especialmente após recente decisão do STF dando pela constitucionalidade da avocação, pelo $\mathrm{CNJ}$, de processos correicionais em andamento nas corregedorias locais, sem contar com a possibilidade de qualquer interessado apresentar perante reclamação disciplinar, diretamente, ao Corregedor-Nacional de Justiça (A reclamação no processo civil brasileiro, in: Nova era do processo civil, p. 208). MARCELO DANTAS ensina, a nosso ver com razão, que "não foi a correição parcial que surgiu em reação à redução das perspectivas recursais contra as interlocutórias, trazida pelo CPC de 1939 - foi, isso sim, sua deturpação, para o fim de se utilizar dela como recurso ou sucedâneo recursal" (Reclamação constitucional, p. 129).
} 
procedendo $^{88}$.Noutros termos, desde sua origem, a reclamação possui natureza jurisdicional, processual, e objetivo de corrigir decisão judicial viciada ou omissão judicial ilegítima.

Outro fator responsável por certa confusão conceitual está ligado à eficácia das decisões judiciais do Supremo Tribunal Federal e do Superior Tribunal de Justiça, que foi consideravelmente alargada pela nova Carta, sobretudo após as Emendas Constitucionais $3 / 1994$ e 45/2004 $4^{89}$.

Bem vista a questão, a reclamação continua sendo um instrumento de "fazer valer decisões"; essas decisões é que sofreram alterações importantes em sua eficácia, as quais se fazem sentir de modo incontroverso na técnica processual aplicável às reclamações. Mas essas transformações relativas à eficácia das decisões cuja autoridade é protegida via reclamação mais interferem na funcionalidade e na técnica processual do que na determinação de sua natureza jurídica.

Mesmo dando enfoque prioritário às funções atuais da reclamação constitucional, parece importante procurar um lugar para encaixar a reclamação de que tratamos no presente trabalho, qual seja aquela voltada a fazer cumprir os precedentes do Supremo Tribunal Federal e do Superior Tribunal de Justiça.

Como será mais bem desenvolvido no próximo capítulo, cuidamos aqui das hipóteses em que a reclamação visa a garantir a autoridade das decisões dotadas de efeitos erga omnes e vinculantes, pois os demais casos não representam novidade alguma. Com efeito, valer-se da reclamação para fazer cumprir o quanto fixado no dispositivo de uma decisão judicial, ou seja, sua executoriedade, faz voltar ao tempo da correição parcial, em que se

\footnotetext{
${ }^{88}$ Nas palavras de MONIZ DE ARAGÃO, a "correição parcial é indubitavelmente um recurso. Recurso clandestino, mas recurso" (A correição parcial, p. 54). Com razão, aliás, o autor, ao afirmar que é contraditório entender se tratar de expressão do direito de petição "um instrumento através do qual as partes possam livrar-se do respeito às regras processuais que, na regulamentação escrupulosa do processo traçado para o exercício do direito de ação, dizem irrecorríveis determinados despachos e atos judiciais" (idem, ibidem).

${ }^{89}$ A EC 3, além de criar a ação declaratória de constitucionalidade, acrescentou o $§ 2 .^{\circ}$ ao artigo 102 , prevendo a eficácia "contra todos e efeito vinculante" das decisões definitivas de mérito proferidas nas ações declaratórias de constitucionalidade. A EC 45 ampliou a eficácia vinculante para as ações diretas de inconstitucionalidade e para as súmulas editados com base nas regras do artigo 103-A, aplicáveis ao controle de constitucionalidade exercido incidenter tantum. Do mesmo modo, "resta evidente que a arguição de descumprimento de preceito fundamental estabeleceu uma ponte entre os dois modelos de controle, atribuindo eficácia geral a decisões de perfil incidental", ao admitir a impugnação ou a discussão direta de decisões judiciais das instâncias ordinárias perante o STF (MEIRELLES, WALD E MENDES, Mandado de segurança e ações constitucionais, p. 841).
} 
pretendia simplesmente o cumprimento do comando sentencial no que tinha de executável, enquanto norma estabelecida para o caso concreto. Esses casos podem ser classificados como exercício do direito de petição ou de representação, como defende ADA PELLEGRINI GRINOVER $^{90}$.

Como visto, o fundamento da reclamação correicional é o mesmo daquela voltada para garantia da autoridade das decisões e da preservação da competência do órgão competente para julgá-la, ou seja, ambas surgiram do poder inerente às Cortes superiores de controlar a atuação dos órgãos subalternos. E mais, do poder de imperium intrínseco a todo ato estatal. Todavia, os institutos se bifurcaram e, graças ao fato de as decisões tomadas em sede de controle de constitucionalidade serem dotadas de natural eficácia ultra partes $^{91}$,a jurisprudência do Supremo Tribunal Federal precisou se debruçar sobre a questão da legitimidade ativa para a reclamação, ou seja, para o problema de se saber quem poderia reclamar pelo cumprimento daquelas suas decisões.

À medida que se expande a eficácia das decisões desses Tribunais (e de outros, como pretende a reforma do Código de Processo $\mathrm{Civil}^{92}$ ), o que poderia ser resolvido por uma mera petição da parte prejudicada pelo ato contrário à decisão superior passa a depender de uma demanda autônoma, veiculada em processo autônomo, especialmente nas hipóteses em que o ato violador não seja jurisdicional ${ }^{93}$.

Em primeiro lugar, portanto, ficou evidente que a reclamação prevista na Constituição Federal de 1988, incluindo a hipótese do artigo 103-A, §3. ${ }^{\circ}$, é modo de exercício da jurisdição pelo STF e pelo STJ - e pelos demais Tribunais que preveem instituto semelhante em seus Regimentos Internos. Por isso, é preciso distanciar o instituto de qualquer ancestral meramente correicional ou administrativo-disciplinar - repetida a ressalva de que a correição parcial não possuía caráter meramente correicional, como o nome poderia transparecer. Trata-se, então, de instrumento processual pelo qual se exerce a Jurisdição e se concede tutela jurisdicional ao interessado.

\footnotetext{
${ }^{90}$ A reclamação para garantia da autoridade das decisões dos tribunais, in: $O$ processo: estudos e pareceres, p. 123-131.

${ }^{1}$ Segundo a doutrina majoritária, os processos de controle abstrato de constitucionalidade são de índole objetiva, não cabendo falar em partes nem em lide.

92 Vide item 1.1.4.

93 Nesse ponto, se, antes mesmo da constitucionalização, já se costumava atribuir ao instituto a natureza de ação, é verdade que, à medida que seu cabimento vem sendo alargado, para atingir, por exemplo, atos administrativos, a reclamação mais se distancia do conceito de recurso e se consolida como verdadeira ação constitucional.
} 
Diante dessa constatação, pouco importa saber em que conceito se encaixa o instrumento: ação, recurso, sucedâneo recursal, incidente processual ${ }^{94}$, remédio processual ou exercício do mero direito de petição ${ }^{95}$. A nosso ver, a única distinção relevante que se pode fazer é a que leva em conta a natureza do ato reclamado e sua eficácia, pois dessa condição decorre a existência ou não de processo e demanda autônoma.

Não podemos concordar, portanto, com quem afirma que a reclamação sempre está desvinculada de um processo já instaurado ${ }^{96}$, pois somente quando impugna ato não jurisdicional é que a reclamação não terá função recursal, ou seja, não será sucedâneo recursal; em todos os outros casos, como se verá abaixo, é nítida a finalidade de cassar a decisão judicial reclamada.

Com efeito, a finalidade única da reclamação voltada a garantir a autoridade das decisões judiciais é cassar os atos que violem essa autoridade. Sendo assim, se se tratar de atos judiciais, não se pode fugir à realidade de estar diante de um sucedâneo recursal, já que não podemos alocá-la na categoria dos recursos, conforme passamos a demonstrar.

Independentemente da crítica de abalizada doutrina ${ }^{97}$, é clássico o conceito formulado por José CARLOS BARBOSA MOREIRA, segundo o qual, no direito processual brasileiro, recurso é "remédio voluntário idôneo a ensejar, dentro do mesmo processo, a

\footnotetext{
${ }^{94}$ Embora manifestada em outra era do desenvolvimento do instituto, interessa mencionar, também, a posição de MONIZ DE ARAGÃO, para quem a reclamação, "longe de ser uma ação, ou um recurso, é um incidente processual, provocado pela parte ou pelo Procurador-Geral, visando a que o Supremo Tribunal imponha a sua competência quando usurpada, explícita ou implicitamente, por outro qualquer tribunal ou juiz" (A correição parcial, p. 110).

95 É comum a doutrina especializada citar, a respeito, a síntese feita pelo MiN. CELSO DE MELLO, no voto proferido na Rcl. 336/SP, verbis: "A reclamação, qualquer que seja a qualificação que se lhe dê - ação (PONTES DE MIRANDA, Comentários ao Código de Processo Civil, tomo V/384, Forense), recurso ou sucedâneo recursal (MOACYR AMARAL SANTOS, RTJ 56/546-548; ALCIDESDE MENDONÇA LIMA, $O$ Poder Judiciário e a Nova Constituição, p. 80, 1989, Aide), remédio incomum (OROZIMBO NONATO, apud CORDEIRO DE MELLO, O processo no Supremo Tribunal Federal, v. 1/280), incidente processual (MONIZDE ARAGÃO, A correição parcial, p. 110, 1969), medida de direito processual constitucional (José Frederico Marques, Manual de Direito Processual Civil, v. 3. , 2. ${ }^{a}$ parte, p.199, item n. 653, 9. ${ }^{a}$ ed., 1987, Saraiva) ou medida processual de caráter excepcional (MIN. DJACI FALCÃO, RTJ 112/518-522) -, configura, modernamente, instrumento de extração constitucional, inobstante a origem pretoriana de sua criação (RTJ 112/504), destinado a viabilizar, na concretização de sua dupla função de ordem político-jurídica, a preservação da competência e a garantia da autoridade das decisões do STF (CF, art. 102, I, 1) e do STJ (CF, art. 105, I, f)" (Rcl. 336/SP, rel. MIN. CELSO DE MeLlo, j. em 19/12/1990, Plenário, DJ 15/03/1991).

${ }^{96}$ ARAKEN DE ASSIS, para quem há duas ordens de sucedâneos: os que abrem processo autônomo e os que incidem sobre processo já instaurado (Manual dos recursos, p. 913). No mesmo sentido, sem explicar, NeRY JR., Teoria geral dos recursos, p. 91.

${ }^{97}$ ARAKEN DE Assis, Manual dos recursos, p. 47-60.
} 
reforma, a invalidação, o esclarecimento ou a integração de decisão judicial que se impugna" 98 .

A partir desse conceito e de alguns seus desdobramentos, os que defendem que a reclamação não pode ter natureza recursal alegam que: (1) não se trata de remédio ensejado dentro "do mesmo processo"; (2) não visa a impugnar uma decisão, mas a assegurar a sua autoridade; (3) o artigo 12 da Lei 9.882/1999 estabelece a irrecorribilidade da decisão tomada no processo da ADPF, o que impede reconhecer a reclamação ali prevista como recurso, e o artigo $7 .^{\circ}$ da Lei da Súmula Vinculante é claro ao afirmar que é cabível a reclamação "sem prejuízo dos recursos ou outros meios admissíveis de impugnação"; (4) os dispositivos constitucionais colocam a reclamação entre a competência originária do STF e do STJ; (5) o interesse do reclamante não depende da sucumbência; (6) o princípio da taxatividade dos recursos e de sua necessária expressa previsão legal; (7) não possui aptidão para retardar ou impedir a formação da coisa julgada ${ }^{99}$.

Entendemos que há grande erro de mira na doutrina acima apontada, que se utiliza de parâmetros equivocados quando faz referência a "mesmo processo" e a "assegurar a autoridade de decisão", esquecendo-se do processo no qual proferida a decisão reclamada. Isso porque é evidente que, para alocar a reclamação no escaninho dos recursos, a decisão "recorrida" não é a decisão paradigma (precedente), mas a decisão que supostamente a viole. É claro que, se encarada como recurso, será um remédio ensejado dentro do "mesmo processo" em que tomada a decisão impugnada, que não se pode confundir com a decisão paradigma, esta, sim, parâmetro de autoridade violada.

Da mesma forma, não convence a alegação pautada na irrecorribilidade das decisões tomadas em ADPF, pois não se trata de impugnar a decisão paradigma - esta deveras irrecorrível - mas sim a decisão que a descumpra.

Em outras palavras, as razões elencadas nos números (1), (2) e (3) acima não se sustentam, pois a reclamação é, sim, ajuizada durante o curso do processo no qual tomada a decisão reclamada, e esta, por sua vez, sendo objeto da impugnação, poderá, sim, ser cassada. O objetivo da reclamação é justamente cassar uma decisão tomada dentro de um

\footnotetext{
${ }^{98}$ Comentários ao Código de Processo Civil, p. 233.

${ }^{99}$ GRINOVER, A reclamação para garantia da autoridade das decisões dos tribunais, p. 127. DANTAS, Reclamação constitucional, p. 452-456. LEONEL, Reclamação constitucional, p. 145-155. LUCON, A evolução da reclamação constitucional e seu emprego para assegurar a autoridade dos precedentes, p. 297.
} 
processo ainda em curso - valendo aqui lembrar o teor da Súmula734 do STF, segundo a qual não cabe reclamação contra decisão transitada em julgado. O requerimento da reclamação não visa a confirmar a decisão paradigma e tampouco a revê-la, mas a revogar a decisão que a não respeitou.

Restariam, assim, as outras razões, indicadas pelos números (4), (5), (6) e (7). Quanto à necessidade de sucumbência, essa parte da doutrina parece estar apegada demais a questões meramente formais, restringindo demais e de propósito o conceito de sucumbência. Ante a ausência de conceito legal a respeito, necessário ter em mente que sucumbir é se ver derrotado, perder. Não há como não reconhecer a sucumbência naquele que recebe uma decisão contrária à sua pretensão ao mesmo tempo em que viola decisão do Supremo Tribunal Federal ou do Superior Tribunal de Justiça; a lei fala apenas em "interessados", e o interesse (necessidade/utilidade) na medida repousa apenas na existência daquela decisão.

O fato de a Constituição Federal colocar a reclamação no rol das competências originárias do inciso I dos artigos 102 e 105 não é capaz, também, de excluir eventual natureza recursal da medida, embora seja indicativo da mens legislatoris. Da mesma forma, o princípio da taxatividade dos recursos não pode ser interpretado a ferro e fogo para, de plano, excluir a existência, ainda que clandestina, de um recurso.

Ocorre, todavia, que em matéria de recurso, como sói acontecer em matéria de direito processual, dada a sua condição de técnica específica dentro da ciência jurídica, vale somente o que está expressamente permitido na lei ${ }^{100}$. Além disso, o último dos argumentos não pode ser ignorado, pois a reclamação não é mesmo capaz de retardar ou impedir a formação da coisa julgada. Ao contrário, pressupõe a inexistência de coisa julgada como condição de cabimento.

De fato, só pode ser considerado recurso o instrumento previsto expressamente em rol taxativo que seja capaz de ao menos retardar a formação da coisa julgada sobre a decisão impugnada. Por isso mesmo, embora a finalidade da reclamação seja idêntica à de um recurso, será melhor alocá-la, como fazem alguns, na vasta classe dos remédios processuais, assim entendidas "todas as medidas mediante as quais, de algum modo, se

\footnotetext{
${ }^{100}$ Esse é o conteúdo do princípio da taxatividade dos recursos (NERY JR., Teoria geral dos recursos, p. 128).
} 
afasta a eficácia de um ato judicial viciado, se retifica o ato ou se produz sua adequação aos requisitos da conveniência ou da justiça"101.

Essa corrente doutrinária nos parece ser a mais adequada, pois consegue abarcar, num mesmo conceito, características de ação e de recurso, já que acaba por reconhecer na reclamação uma ação especial voltada a cassar uma decisão judicial violadora da competência ou da autoridade de uma decisão superior, mas também não exclui em seus limites as hipóteses em que o ato reclamado é não jurisdicional.

É ação porque não está no rol taxativo dos recursos nem os acompanha na seleção feita pelos artigos 102 e 105 da CF/1988. Mas veicula pedido específico de reforma do ato reclamado por violação da competência ou de alguma decisão do STF e do STJ - possua ele natureza judicial ou não.

Como visto antes, essa posição parece ter sido a adotada pelo Projeto de novo Código de Processo Civil ${ }^{102}$, que aloca a reclamação no Capítulo XIX do Título I ("Da Ordem dos Processos e Dos Processos de Competência Originária dos Tribunais") do Livro III ("Dos Processos nos Tribunais e Dos Meios de Impugnação das Decisões Judiciais"), precisamente nos artigos 985 a 990, topologicamente posterior aos capítulos relativos à rescisória e ao incidente de resolução de demandas repetitivas. E, para dissipar qualquer dúvida, o Título II, imediatamente posterior, trata de modo exclusivo "Dos Recursos".

A solução aventada impede que se aceite a teoria de ADA PELLEGRINI GRINOVER sobre a reclamação ser um modo de exercício do direito de petição, previsto no artigo $5 .^{\circ}$, XXXIV, da $\mathrm{CF}^{103}$, ainda que o próprio Supremo Tribunal Federal a tenha adotado ao

\footnotetext{
${ }^{101}$ Essa é a posição de DinAMARCo (A reclamação no processo civil brasileiro, p. 204). No mesmo sentido, SERGIO MASSARU TAKOI, que a vê como remédio constitucional (Reclamação constitucional, p. 45-46).

${ }_{102}$ Referimo-nos, novamente, ao texto final aprovado pela Comissão Temporária do Senado (votação dia 04/12/2014), relativo ao Projeto de Lei 8046/2010, oriundo da Câmara dos Deputados, em revisão ao PLS 166/2010. Disponível em: <http://www12.senado.gov.br/noticias/materias/2014/11/27/novo-codigo-deprocesso-civil-comissao-vota-sugestoes-dos-deputados-no-dia-4>. Acesso em: 26 dez. 2014). Até a impressão desse trabalho, não estava publicada a versão final aprovada pelo Senado.

${ }^{103}$ A reclamação para garantia da autoridade das decisões dos tribunais, in:O processo:estudos e pareceres, $\mathrm{p}$. 123-131. No texto, a autora incorre no mesmo equívoco de ponto de vista que apontamos quando tratamos dos argumentos 1,2 e 3 , pois coloca como foco a decisão paradigma e o processo em que ela foi tomada para recusar a natureza recursal da reclamação.
} 
analisar a natureza jurídica da reclamação prevista no Regimento Interno do Tribunal de Justiça do Ceará ${ }^{104}$.

Ocorre que tanto o texto de doutrina quanto o acórdão do STF trataram da hipótese mais corriqueira do uso da reclamação, qual seja aquela ajuizada pela parte do processo no qual foi proferida a decisão judicial violada ou não cumprida. Como já afirmado acima, nesses casos a reclamação ainda guarda muita semelhança com a correição parcial, embora permita a cassação da decisão reclamada.

Em seu artigo, a autora se utilizou do argumento exposto pelo MiNISTRO NELSON HUNGRIA no voto que proferiu na Reclamação 141/1952, segundo o qual se trataria "de simples representação, em que se pede ao STF que faça cumprir o julgado tal como nele se contém"105. Fácil notar que, à época, não se vislumbrava o uso da reclamação por aqueles afetados pela eficácia erga omnes e vinculante da decisão do STF, cogitando-se apenas de seu uso originário das correições parciais.

Do mesmo modo, quando o STF reconheceu a natureza jurídica de simples expressão do direito de petição, tratou apenas das hipóteses cabíveis perante os Tribunais de Segundo Grau, cuja competência para expedir precedentes vinculantes e erga omnes é muito restrita

\footnotetext{
${ }^{104}$ AÇÃO DIRETA DE INCONSTITUCIONALIDADE. ARTIGO 108, INCISO VII, ALÍNEA I DA CONSTITUIÇÃO DO ESTADO DO CEARÁ E ART. 21, INCISO VI, LETRA $J$ DO REGIMENTO DO TRIBUNAL DE JUSTIÇA LOCAL. PREVISÃO, NO ÂMBITO ESTADUAL, DO INSTITUTO DA RECLAMAÇÃO. INSTITUTO DE NATUREZA PROCESSUAL CONSTITUCIONAL, SITUADO NO ÂMBITO DO DIREITO DE PETIÇÃO PREVISTO NO ARTIGO 5.․, INCISO XXXIV, ALÍNEA A DA CONSTITUIÇÃO FEDERAL. INEXISTÊNCIA DE OFENSA AO ART. 22, INCISO I DA CARTA. 1. A natureza jurídica da reclamação não é a de um recurso, de uma ação e nem de um incidente processual. Situase ela no âmbito do direito constitucional de petição previsto no artigo $5 .^{\circ}$, inciso XXXIV da Constituição Federal. Em consequência, a sua adoção pelo Estado-membro, pela via legislativa local, não implica em invasão da competência privativa da União para legislar sobre direito processual (art. 22, I da CF). 2. A reclamação constitui instrumento que, aplicado no âmbito dos Estados-membros, tem como objetivo evitar, no caso de ofensa à autoridade de um julgado, o caminho tortuoso e demorado dos recursos previstos na legislação processual, inegavelmente inconvenientes quando já tem a parte uma decisão definitiva. Visa, também, à preservação da competência dos Tribunais de Justiça estaduais, diante de eventual usurpação por parte de Juízo ou outro Tribunal local. 3. A adoção desse instrumento pelos Estados-membros, além de estar em sintonia com o princípio da simetria, está em consonância com o princípio da efetividade das decisões judiciais. 4. Ação direta de inconstitucionalidade improcedente (ADI 2.212-1/CE, rel. MIN. ElLEN GRACIE, v. m, j. 02/10/2003, DJ 20/11/2003). Interessante ler o parecer do então Advogado-Geral da União, GILMAR MENDES, no qual se sustenta que "o instituto da reclamação constitui inexorável decorrência da eficácia geral e do efeito vinculante do controle abstrato de normas deferido pela Constituição Federal aos Tribunais de Justiça". Em conclusão, o hoje ministro do STF, propunha a procedência da ADI para atribuir interpretação conforme de modo que a referida reclamação somente fosse cabível para preservar a eficácia das decisões proferidas em sede de controle concentrado de constitucionalidade perante os Tribunais de Justiça dos Estados, em franco paralelismo com as hipóteses previstas na CF/1988.

${ }^{105}$ Ob. cit., p. 129.
} 
e, ao que tudo indica, nem sequer foi aventada durante o julgamento ${ }^{106}$. Assim, não se pode utilizar esse julgado para afirmar que o STF atribui essa natureza à reclamação constitucional.

Vale ainda mencionar que, segundo ADA PELLEGRINI, não se pode aceitar a tese de que a reclamação seria uma ação, pois esta tem por conteúdo o exercício da jurisdição, assegurando às partes não somente a resposta do Estado, mas ainda o direito ao contraditório, enquanto a reclamação visa apenas a assegurar a eficácia do provimento definitivo que já concedeu a tutela jurisdicional, e não se poderia cogitar de assegurar aos interessados uma reabertura da discussão contraditória que propiciou aquela tutela ${ }^{107}$.

Incorre a autora, a nosso ver, no mesmo equívoco apontado acima e consistente em levar em consideração a decisão paradigma e o processo que a originou, em vez de ter em mira a decisão reclamada e o processo no qual ela foi proferida. Partindo do ponto de vista adequado, é impossível negar a natureza de ação à reclamação, pois é evidente que ali se exerce a jurisdição e com respeito integral ao contraditório, nos mesmos limites aceitos, aliás, no mandado de segurança e outros remédios constitucionais.

Por tais motivos, concordamos com RICARDO LEONEL quando conclui que a reclamação constitucional ostenta todos os dados que caracterizam a demanda judicial, ou seja, o exercício do direito de ação, dentre os quais se destacam: (a) a existência de uma lide subjacente, (b) a resposta judicial nela obtida destina-se a tornar-se definitiva, por meio da coisa julgada, (c) inaugura-se uma relação processual autônoma, com o respectivo procedimento, (d) a necessária observância das garantias constitucionais do processo ${ }^{108}$.

De todo modo, seja qual for natureza jurídica que se lhe reconheça, são inegáveis seu status constitucional e o fato de que sua regulamentação está nas mãos do Supremo Tribunal Federal soberanamente, na qualidade de intérprete definitivo da Constituição. Como bem já se expressou o Ministro CELSO DE MELLO, em voto já citado:

\footnotetext{
${ }^{106}$ Refere-se ao julgamento da ADI 2.212-1/CE, rel. MiN. Ellen GraCIE, v. m., j. 02/10/2003, DJ 20/11/2003. Cabe mencionar que, mais recentemente, o STF entendeu pela inconstitucionalidade da reclamação prevista no RITST, em ementa assim formulada: "Reclamação - Regência - Regimento Interno Impropriedade. A criação de instrumento processual mediante regimento interno discrepa da Constituição Federal. Considerações sobre a matéria e do atropelo da dinâmica e organicidade próprias do Direito" (RE 405.031-5/AL, Pleno, rel. MIN. MARCO AURÉLIO, j. 15/10/2008, DJe 16/04/2009).

${ }^{107}$ Ob. cit., p. 128.

${ }^{108}$ Ob. cit., p. 175.
} 
"A reclamação, qualquer que seja a qualificação que se lhe dê, [...] configura, modernamente, instrumento de extração constitucional, inobstante a origem pretoriana de sua criação (RTJ 112/504), destinado a viabilizar, na concretização de sua dupla função de ordem políticojurídica, a preservação da competência e a garantia da autoridade das decisões do STF (CF, art. 102, I, l) e do STJ (CF, art. 105, I, f)"109.

Conclui-se, portanto, que a reclamação constitucional é uma ação que veicula tutela jurisdicional desconstitutiva ${ }^{110} \mathrm{e}$, quando o ato impugnado for uma decisão judicial, possui função idêntica à de um recurso na medida em que se limita a cassar a decisão reclamada com ou sem determinação de que outra seja proferida ${ }^{111}$. Em outras palavras, trata-se de ação constitucional com funções distintas. Nessas circunstâncias, postas as balizas acima, é possível concordar com RICARDO LEONEL quando afirma que "o instituto é um só e deve ser qualificado de modo uniforme" ${ }^{, 12}$.

\subsection{Reclamação e recurso: concorrência de meios de impugnação}

Um ponto merece ser mais bem analisado, qual seja a pertinência da previsão da reclamação como sucedâneo recursal. Estamos tratando, portanto, dos casos em que o ato impugnado é uma decisão judicial.

A partir do momento em que o Estado tomou pra si o monopólio da jurisdição, aceitou o encargo de ampliar ao máximo o acesso dos cidadãos ao seu exercício. Por isso, são excepcionalíssimas as restrições à garantia constitucional de acesso ao Poder Judiciário insculpida no artigo 5. ${ }^{\circ}, \mathrm{XXXV}$, da CF/1988. Com efeito, para se tutelar um direito violado ou em vias de sê-lo, o seu titular deve ter a seu dispor não apenas a possibilidade de ativar o Estado-juiz, mas sobretudo as condições reais para que o direito de ação seja exercido em sua plenitude, sem restrições indevidas e mediante o devido processo legal.

\footnotetext{
${ }^{109}$ Rcl. 336/SP, rel. MIN. CELSO DE MELLO, j. em 19/12/1990, Plenário, DJ 15/03/1991. No mesmo sentido, mais recentemente, Rcl. 7.759, rel. MIN. CELSO DE MELLO, dec. mon., j. 26/02/2009, DJE 04/03/2009.

${ }^{110}$ TEORI ZAVASCKI defende uma natureza executiva da reclamação, como instrumento adequado para fazer valer a força qualificada que caracteriza as decisões dotadas de eficácia vinculante, querendo demonstrar o fato de que as reclamatórias são ações de finalidade específica, voltadas para o cumprimento da decisão paradigma (Eficácia das sentenças na jurisdição constitucional, p. 63).

${ }^{111}$ É o que se retira dos artigos 17 da Lei Federal 8038/90 (“Julgando procedente a reclamação, o Tribunal cassará a decisão exorbitante de seu julgado ou determinará medida adequada à preservação de sua competência") e 7. $.^{\circ} \S 2 .^{\circ}$, da Lei Federal 11.417/2006 ("Ao julgar procedente a reclamação, o Supremo Tribunal Federal anulará o ato administrativo ou cassará a decisão judicial impugnada, determinando que outra seja proferida com ou sem aplicação da súmula, conforme o caso").

${ }^{112}$ Reclamação constitucional, p. 164.
} 
Não faria sentido garantir o acesso ao Judiciário e não garantir os meios necessários à concretização desse acesso. De fato, o direito à tutela jurisdicional deve ser analisado sob três perspectivas: (1) do acesso à justiça; (2) da adequação da tutela; (3) da efetividade da tutela. $\mathrm{O}$ acesso à justiça diz respeito à amplitude da prestação da tutela jurisdicional, ao momento em que pode ser proposta a ação e ao custo financeiro do processo. O processo deve ser capaz de realizar o direito material, tal como estabelecido no plano ideal da lei. Pensar de forma diversa seria esvaziar não apenas o direito à tutela jurisdicional como também o próprio direito material ${ }^{113}$.

Entretanto, não se pode fazer da garantia constitucional uma leitura descolada da realidade judiciária contemporânea, tomando "ares tão ufanistas quanto irrealistas", a ponto de contribuir para a sua própria inviabilização pelo estímulo desbragado ao demandismo judiciário. Como adverte Rodolfo DE CAMARgo MAnCuso, “o inciso XXXV do art. 5. ${ }^{\circ}$ da CF/1988 não autoriza a interpretação à outrance, usualmente feita, e que tem permitido inferir que a oferta de justiça estatal está disponibilizada, em modo franco, genérico e prodigalizado, a toda e qualquer situação de interesse contrariado ou insatisfeito, como fora o Judiciário um guichê geral de reclamações"114.

Nada obstante o futuro Código de Processo Civil ter alocado a reclamação entre os meios de impugnação das decisões judiciais, ou seja, entre os chamados "sucedâneos recursais", é de se indagar se, de fato, seu cabimento se amolda às hipóteses em que se admite o uso de instrumentos substitutivos de recursos. Estamos falando da exigência de que haja uma lacuna no sistema como condição para que outro instituto adquira funcionalidade recursal.

Quem quer que se debruce sobre a legislação processual brasileira chegará à conclusão de que os recursos previstos são mais que suficientes para garantir a legalidade e a correção das decisões judiciais e o respeito incontestável ao devido processo legal, ainda que se entenda que o duplo grau de jurisdição não lhe seja uma garantia intrínseca. O rol

\footnotetext{
${ }^{113}$ SARLET, MARINONI E MitidiERO, Curso de direito constitucional, p. 627-639.

${ }^{114}$ Acesso à justiça, p. 194-195. Lembra, o autor, que "numa abordagem ponderada e aderente à realidade judiciária nacional, cabe, desde logo, reconhecer que aquele enunciado é precipuamente endereçado ao legislador, antes que ao jurisdicionado, pela boa razão de que este último não tem controle sobre a criação de norma legal futura que pudesse porventura excluir da apreciação judicial algum histórico de direito lesado ou ameaçado".
} 
do artigo 496 do Código de Processo Civil comprova que toda decisão judicial é, em princípio e por princípio, recorrível no Brasil ${ }^{115}$.

Todavia, mesmo com todo esse amplo manancial de mecanismos recursais, é possível encontrar falhas no sistema, o que tem permitido o desenvolvimento de outros instrumentos com finalidade de impugnar decisões judiciais. A doutrina costuma elencar vários exemplos, como a rescisória, a remessa obrigatória, o mandado de segurança contra ato judicial, o pedido de reconsideração e a correição parcial $^{116}$.

Como ensina ARAKEN DE ASSIS, essa classificação se dá por exclusão, ou seja, faltando alguma característica essencial do conceito de recurso, e desde que a finalidade seja impugnar uma decisão judicial, estaremos diante de um sucedâneo recursal. Para evitar uma variedade que viesse a diluir a precisão da ideia, o autor entende que o verdadeiro sucedâneo recursal é o mecanismo que, alheio ao quadro oficial dos recursos, impugna o provimento judicial sem criar processo autônomo ${ }^{117}$.

É pressuposto de cabimento do sucedâneo recursal o fato de não haver previsão de recurso na hipótese (ou que o recurso previsto não seja dotado de efeito suspensivo), ou seja, o caráter subsidiário. Não faria mesmo sentido, ainda mais no Brasil, onda a duração razoável do processo é garantia constitucional, prodigalizarem-se os meios de impugnação de decisões judiciais a ponto de caber, ao lado do recurso, outro mecanismo processual para o mesmo fim. Por esse motivo, desde sua origem, o mandado de segurança contra ato judicial só é permitido nos casos em que não caiba recurso.

Todavia, como já se pode perceber, ressalvados os casos em que o ato reclamado não possui natureza jurisdicional, a reclamação atua paralelamente aos recursos e aos demais meios impugnativos previstos em lei, concorrendo de forma, por assim dizer, "desleal" com eles, pois representa um atalho para se chegar diretamente aos Tribunais mais altos da

\footnotetext{
${ }^{115}$ FLÁVIO CHEIM JORGE lembra que a existência dos recursos está ligada à falibilidade e à insatisfação humanas e que seu uso há de representar o equilíbrio entre a tempestividade da tutela jurisdicional e a sua correção. Por isso, o sistema processual é cuidadoso ao prever hipóteses limitadas de recursos, para que não haja uma multiplicação indevida que prejudique a própria efetividade da tutela jurisdicional (Teoria geral dos recursos cíveis, p. 20).

${ }^{116}$ NeRY JR., Teoria geral dos recursos, p.; FLÁVIO CHEIM JoRgE, Teoria geral dos recursos cíveis, p. $182 \mathrm{e}$ ss.; ARAKEN DE ASSIS, Manual dos recursos, p. 909 e ss.

${ }^{117}$ Manual dos recursos, p. 912.
} 
hierarquia constitucional, sem as mesmas condições de admissibilidade rigorosíssimas aplicáveis aos recursos excepcionais, que não encontram paralelo na reclamação ${ }^{118}$.

Algo, portanto, há de estar equivocado nessa amplitude que se tem dado ao cabimento da reclamação, pois não parece razoável - ainda mais em um sistema judiciário abarrotado como é a Justiça Brasileira - existirem dois mecanismos paralelos e concorrentes predispostos a impugnar certas decisões judiciais. Para as hipóteses em que não haja recurso cabível ou não seja dotado de efeito suspensivo, por exemplo, seria o caso de indagar por que não prever a utilização do mandado de segurança antes de prever a reclamação direta ao órgão de cúpula?

O fato de a reclamação não ser mais cabível depois de transitada em julgado a decisão reclamada não interfere no quanto exposto, pois até o trânsito são cabíveis os dois instrumentos de impugnação. Além disso, a jurisprudência do Supremo Tribunal Federal tem-se firmado no sentido de que se trata de mera condição de admissibilidade da reclamação quando do ajuizamento, para evitar sua utilização como substituto da ação rescisória. Todavia, se a decisão reclamada transitar em julgado posteriormente - ou porque não imposto o recurso ou por ter sido ele rejeitado ou desprovido -,a reclamação permanece de pé e deverá ser julgada, pois não há prejudicialidade entre os meios de impugnação $^{119}$. Cabe, ainda, mencionar o entendimento do Supremo segundo o qual, se a decisão reclamada for substituída pelo julgamento do recurso contra ela interposto, a reclamação restará prejudicada ${ }^{120}$.

Forçoso notar que o cabimento da reclamação paralelamente ao do recurso previsto para o caso representa uma duplicidade de mecanismos de impugnação da mesma decisão incompatível com o atual estágio de desenvolvimento do sistema processual. Enquanto se discute a redução dos recursos ou de seus efeitos, com objetivo de valorizar as instâncias inferiores e reduzir o tempo de duração dos processos, amplia-se o cabimento da

\footnotetext{
${ }^{118}$ Por exemplo, a reclamação não exige, por óbvio, o requisito do prequestionamento, nem se submete ao rigor da verificação do recolhimento das custas recursais, já que se aplicam a ela as regras flexíveis relativas à admissibilidade das petições iniciais, incluindo a possibilidade de emenda (Rcl. $16582 \mathrm{AgR} / \mathrm{ES}, 1{ }^{\mathrm{a}}{ }^{\mathrm{a}} \mathrm{T}$., rel. MIN. DiAS TOFFOLI, j. 05/08/2014, DJe 08/10/2014).

119“'RECLAMAÇÃO - COISA JULGADA SUPERVENIENTE - VERBETE N. 734 DA SÚMULA DO SUPREMO - INADEQUAÇÃO. Descabe observar o Verbete n. 734 da Súmula do Supremo quando o trânsito em julgado do ato impugnado ocorre após a formalização da reclamação" (Rcl. $16021 \mathrm{AgR} / \mathrm{SP}, 1$. $^{\mathrm{a}}$ T., rel. MiN. MARCO AURÉLIO, j. 25/11/2014, DJe 17/12/2014).

${ }^{120}$ Rcl. 12727/AP, Plenário, rel. MIN. LuIZ FuX, j. 03/11/2011, DJe 22/11/2011.
} 
reclamação para que seja possível sua utilização como meio de encurtar o caminho que leva até as Altas Cortes da pirâmide do Poder Judiciário brasileiro.

Nesse passo, a aprovação do novo Código de Processo Civil representa uma verdadeira "implosão" do sistema recursal, pois o legislador reformista parece não ter-se dado conta de que a reclamação não vem para suprir lacuna daquele sistema, ou seja, não é um mecanismo de complementação das hipóteses de impugnação das decisões judiciais. Ao contrário, vem concorrer com os recursos e de tal forma incoerente e contraproducente que exige a interposição do respectivo recurso como condição de procedibilidade da reclamação - na linha de como a disciplinam o Supremo Tribunal Federal e o Superior Tribunal de Justiça. Ou seja, o sistema exige a utilização de dois instrumentos voltados ao mesmo desiderato, qual seja cassar as decisões impugnadas.

Como ensina MARCElo PACHECO MACHADO, é plenamente viável falar em decisões judiciais inconstitucionais quer por violarem uma norma constitucional material ou formal quer por se basearem em lei já declarada inconstitucional pelo Supremo, mas, em ambos os casos, serão impugnáveis pelos meios normais previstos no ordenamento processual, ou seja, recursos e sucedâneos recursais ${ }^{121}$.

Em outros termos, o fato de a norma concreta fixada na sentença ou em uma decisão interlocutória violar preceito da Constituição ou se basear em lei já considerada inconstitucional pelo Supremo Tribunal Federal não a torna "mais importante" que qualquer outra decisão viciada por ser ilegal; não pode haver distinção qualitativa entre os vícios da ilegalidade e da inconstitucionalidade, sobretudo se considerarmos a prodigalidade de nossa Constituição Federal $^{122}$.

Mesmo as hipóteses de desobediência da súmula vinculante do Supremo Tribunal podem ser veiculadas mediante os recursos ordinários, como o são as discrepâncias com qualquer outra súmula, pois, sempre, na base, estar-se-á descumprindo uma norma constitucional e, assim, cometendo uma ilegalidade lato sensu.

Tanto isso é verdade que o artigo 7. ${ }^{\circ}$ da Lei 11.417/2006 estabelece ser cabível a reclamação "sem prejuízo dos recursos ou outros meios admissíveis de impugnação", coroando a concorrência de meios voltados a controlar a eficácia dos verbetes vinculantes.

\footnotetext{
${ }^{121}$ Decisão inconstitucional, e daí?, p. 220 e ss.

${ }^{122}$ Idem, ibidem.
} 
Essa pluralidade de meios de controle talvez se justifique em razão da própria relevância de que são dotados os precedentes do Supremo Tribunal Federal, além de ser coerente com o movimento que pretende adotar no Brasil uma filosofia de respeito a precedentes. Mas não seria de todo absurdo levantar a hipótese de ter o legislador, com essa prodigalidade, procurado tornar mais aceitável o próprio instituto da "súmula vinculante".

E embora não haja idêntica previsão nas Leis 8.038/1990 e 9.882/1999 nem no RISTF e no RISTJ, parece indefensável supor que o respeito à eficácia vinculante dos precedentes judiciais seja controlado apenas pela reclamação constitucional. Ela, sem dúvida, é o meio mais eficaz, rápido e econômico para se exigir o respeito às teses fixadas pelos Tribunais, pelo simples fato de ser julgada diretamente por quem foi responsável por editar a decisão paradigma. Mas essas qualidades todas, em detrimento de outros meios de impugnação, cobram um preço alto demais do sistema.

Em síntese, no mínimo, é heterodoxa e coloca em risco o próprio equilíbrio do sistema de impugnações das decisões judiciais a previsão e cabimento de sucedâneo recursal em concorrência com recurso de forma generalizada e ilimitada. 


\section{CAPÍTULO 2 -PRECEDENTE JUDICIAL NO DIREITO BRASILEIRO}

\subsection{Decisão judicial como fonte do Direito}

Antes de adentrarmos, propriamente, no tema e definirmos um conceito de precedente judicial para os fins do presente estudo, interessa traçar, ainda que de relance, qual o papel das decisões judiciais sob o ponto de vista da criação das normas jurídicas. Nesse mister, vale lembrar que o Direito, enquanto disciplina da convivência humana ${ }^{123}$, é o intercâmbio perene de fatos, valores e normas, ou, nas palavras de MiguEl REALE, tem por característica essa "estrutura tridimensional, na qual fatos e valores se dialetizam, isto é, obedecem a um processo dinâmico" ${ }^{124}$.

Todavia, muito embora se trate de elementos essenciais indissociáveis do objeto, é possível cindi-lo, didaticamente, para focar o estudo apenas na norma jurídica, caracterizada por ser uma "estrutura proposicional enunciativa de uma forma de organização ou de conduta, que deve ser seguida de maneira objetiva e obrigatória" ${ }^{125}$; essa "forma de organização ou de conduta" representa um fato de cuja existência depende a incidência da norma ${ }^{126}$.

As normas jurídicas nascem de formas variadas, assim como são variados seus conteúdos. A propósito, uma das classificações possíveis da norma jurídica leva em conta, justamente, sua fonte ou sua forma de produção, para concluir que podem ser legais, consuetudinárias, jurisprudenciais e doutrinárias ${ }^{127}$.

\footnotetext{
${ }^{123}$ GOFFREDO TELLES JR., A criação do direito, p. 471-479.

${ }^{124}$ Lições preliminares de direito, p. 64-68. Nas palavras e com os destaques do autor: "onde quer que haja um fenômeno jurídico, há sempre e necessariamente, um fato subjacente (fato econômico, geográfico, demográfico, de ordem técnica etc.); um valor, que confere determinada significação a esse fato, inclinando ou determinando a ação dos homens no sentido de atingir ou preservar certa finalidade ou objetivo; e, finalmente, uma regra ou norma, que representa a relação ou medida que integra um daqueles elementos ao outro, o fato ao valor" (ob. cit., p. 65).

${ }^{125}$ REALE, ob. cit., p. 95.

${ }^{126}$ MARIA HELENA DiNIZ define norma jurídica como um modelo funcional que contém, em si, o fato, pois, sendo um tipo geral oposto à individualidade concreta, pode ser adaptada a esta última; a esta adaptação ou enquadramento representa o fenômeno da subsunção (As lacunas no direito, p. 269-271). Nos dizeres de REALE, "a previsão do legislador raro é de um fato ou evento particular e único, mas sim de uma "espécie de fato', ou um 'fato-tipo', ao qual poderão corresponder, com maior ou menor rigor, múltiplos fatos concretos" (ob. cit., p. 100).

${ }^{127}$ REALE ainda acrescenta as negociais, defendendo que seriam produtos da autonomia da vontade. Para ele, então, "sendo a norma jurídica a expressão de um dever ser de organização ou de conduta, pode ela resultar de distintos processos, como o legislativo, o jurisdicional, o costumeiro e o negocial" (ob. cit., p. 121).
} 
Fala-se, outrossim,nas chamadas fontes de cognição do Direito, indicando os elementos a partir dos quais o estudioso toma conhecimento, especialmente histórico, de determinada experiência jurídica. Nesta acepção, toda e qualquer forma de apreensão do fenômeno jurídico é considerada fonte, desde uma lasca de pedra até uma negociação via rede mundial de computadores ${ }^{128}$.

Evidente que o estudo da evolução dos precedentes de determinado sistema jurídico fornecerá fundamentais elementos de cognição das transformações por que passou no decorrer dos tempos. Da mesma forma, não é de todo desarrazoado cogitar certa coincidência de conceitos, quando constatamos que, em especial nos países do common law, os precedentes judiciais são a verdadeira fonte de conhecimento histórico do sistema jurídico. Mas não é nessa acepção que tratamos de colocar o problema dos precedentes como fontes do Direito; colocamo-lo sob aquele primeiro prisma: como fonte da norma jurídica, ou seja, do direito objetivo.

Talvez, de fato, a principal classificação das fontes do Direito seja a que as distingue entre fontes materiais e formais. As primeiras são todos os fatores que influem na gênese das regras jurídicas, circunstâncias variadas, de natureza histórica, social, econômica e até filosófica; todos, na verdade, externos ao fenômeno jurídico, devendo, por isso, serem estudados pela Sociologia Jurídica, pela Política ou pela História. As segundas, por sua vez, são as formas de expressão da regra jurídica, o verdadeiro núcleo da ciência jurídica.

Interessa saber, entre essas formas de expressão das normas jurídicas, qual a posição das decisões judiciais, qual sua natureza e quais as distinções entre elas e outros modos de exteriorização do Direito. Nessa empreitada, não se foge de perscrutar o papel desempenhado pelo Poder Judiciário: se de mero solucionador de casos concretos (função retrospectiva), de verdadeiro agente criador do Direito (função prospectiva) ou ambos concomitantemente. Como bem lembra JosÉ RoGÉRIO CRUZ E TUCCI, o precedente não se

\footnotetext{
${ }^{128}$ AZEVEDO; CRUZ E TUCCI. Lições de história do processo civil romano, p. 27-28. Esses autores classificam tais fontes históricas de primárias e secundárias. Enquanto estas são as que permitem, por indução, chegar o mais próximo possível do conhecimento buscado, aquelas retratam, sem qualquer outro processo intelectivo intermediário, como era determinado sistema jurídico (idem, ibidem).
} 
confunde com o costume; é a homologação ou aprovação das regras consuetudinárias pelos juízes que viabiliza sua transformação em precedente ${ }^{129}$.

Outra reflexão cabível de ser feita é aquela que tenta explicar o modo pelo qual os fenômenos são recebidos pelo sistema jurídico com eficácia de norma; em outras palavras, conhecer os porquês do reconhecimento ou não da universalidade e da generalidade da regra editada. A doutrina costuma apontar, de modo geral, duas justificativas para esse reconhecimento: a autoridade da decisão ou a força de suas razões. E, ao responder a essa questão, constatamos que, de fato, apesar das grandes diferenças históricas, os sistemas da common law e da civil law acabam por encarar de forma muito semelhante esses dois aspectos fundamentais da decisão judicial, ora enfatizando esta, ora aquela ${ }^{130}$.

A propósito, como será tratado logo mais, uma mirada de alguns séculos atrás permite constatar, por exemplo, que o regime de assentos da Casa de Suplicação lusitana brotou no seio de um sistema de origem romano-germânica. Por outro lado, ao contrário do que se costuma dissipar no vulgo, a experiência jurídica romana não se baseava no direito legislado, mas era, sim, fruto da doutrina dos jurisconsultos e da jurisdição dos pretores ${ }^{131}$.

Ocorre que a evolução do sistema do direito legislado encontrou um verdadeiro desvio de rota na força do constitucionalismo, sobretudo norte-americano, que, baseado na "força dos princípios" e em normas abertas, exigiu magistrados preparados para, necessariamente, irem além do texto legal ${ }^{132}$.

\footnotetext{
${ }^{129}$ Precedente judicial como fonte do direito, p. 10. Diferentemente, partindo da visão de jurista do civil law, CARLOS MAXIMILIANO afirma que a "jurisprudência é a causa mais geral da formação de costumes jurídicos nos tempos modernos" (Hermenêutica e aplicação do direito, p. 153).

${ }^{130}$ CRUZ E TUCCI, citando Martin Kriele, lembra que, "[n]a teoria do direito europeu-continental, o acento mais forte é colocado sobre o elemento da autoridade, naquela anglo-americana, sobre o elemento razão", mas "na realidade jurídica, os precedentes gozam, para os juízes dos sistemas de tradição romanística, da mesma importância que ostentam aos juízes da common law". Por isso, afirma: "o common lawyer e o iuris peritum, este forjado na tradição do direito romano, procediam, no passado, e procedem, no presente, guardadas as devidas fronteiras e feitas as necessárias ressalvas, exercendo um raciocínio não muito diverso" (Precedente judicial como fonte do direito, p. 23 e 26). Na mesma linha, THOMAS DA ROSA DE BUSTAMANTE sustenta que esse equilíbrio entre razão e autoridade é a nota de semelhança que permite desenhar uma teoria normativa dos precedentes judiciais válida para ambos os sistemas jurídicos (Teoria do precedente judicial, p. 114).

${ }_{131}$ Cf. ReALe, ob. cit., p. 98, nota de rodapé 1.

${ }^{132}$ Lembra MARINONI que o "civil law vive, atualmente, a contradição entre o juiz real e o juiz dos livros ou das doutrinas acriticamente preocupadas apenas em justificar que a nova função do juiz cabe dentro do modelo do princípio da separação dos poderes. Na verdade, a doutrina esquece de esclarecer que o juiz da Revolução Francesa nasceu natimorto" (Precedentes obrigatórios, p. 100). V. tb., do mesmo autor: A ética dos precedentes, p. $52-56$.
} 
Os mecanismos hermenêuticos utilizados pela doutrina constitucionalista moderna implicaram a ampliação do conteúdo semântico dos textos legislados, a forçar o órgão jurisdicional a trabalhar no limite da criação do direito ${ }^{133}$.Independentemente da posição que se adote a respeito de saber se o juiz cria o direito ou apenas o descobre a partir da interpretação da norma ${ }^{134}$, o fato é que leis mais abertas, com cláusulas indeterminadas, exigem uma atuação judicial muito mais complementar e criativa. Nesse passo, os juízes vão-se distanciando do ideal montesquiano do juiz bouche de la loi.

No Brasil, o grande marco dessa mudança foi a promulgação da Constituição Federal de 1988 , a partir de quando se iniciou uma verdadeira mudança de perspectiva ${ }^{135}$. Mas essa abertura do texto legal, muito influenciada por aquela constitucionalização, ao mesmo tempo em que atribuiu às decisões judiciais um grau elevadíssimo de subjetividade ${ }^{136}$, veio exigir do Poder Judiciário muito mais coerência e logicidade, as quais somente se alcançarão pela racionalização da Jurisprudência, com respeito aos precedentes.

Portanto, respeitar as decisões dos órgãos predispostos constitucionalmente a uniformizar a interpretação da lei federal e do texto constitucional (órgãos de vértice), mais

\footnotetext{
${ }^{133}$ Há quem afirme que "a criatividade judicial, embora reconhecida, deve ser vista como algo inevitável, não como algo dotado de valor. Sua raiz está justamente nos limites da razão prática, em suas defíciências" (BUSTAMANTE, ob. cit., p. 461). É preciso ponderar, entretanto, que a criatividade inevitável nada mais é que a própria interpretação/aplicação do direito.

${ }^{134}$ Impossível driblar as conclusões de EROS GRAU: "Não existe um terreno composto de elementos normativos, de um lado, e elementos reais ou empíricos, do outro. Por isso, a articulação ser e dever-ser (a relação norma-fato) é mais que uma questão da filosofia do direito. É questão atinente à estrutura da norma jurídica. Tomada na sua transposição prática; e, por consequência, atinente à estrutura deste processo de transposição. Isso significa - repito - que a norma é produzida, pelo intérprete, não apenas a partir de elementos colhidos no texto normativo (mundo do dever-ser), mas também a partir de elementos do caso ao qual será aplicada - isto é, a partir de dados da realidade (mundo do ser) [...] Por isso inexistem soluções previamente estruturadas - como produtos semi-industrializados em uma linha de montagem - para os problemas jurídicos. O trabalho jurídico de construção das normas aplicáveis a cada caso é trabalho artesanal. Cada solução jurídica, para cada caso, será sempre, renovadamente, uma nova solução" (ob. cit., p. 54-55).

${ }^{135}$ Segundo EROS GRAU: "No futuro, quando o pesquisador da história do direito brasileiro se detiver sobre a Constituição de 1988 e as contribuições doutrinárias a partir dela desenvolvidas, por certo aí encontrará grande mudança de perspectiva - ou, como é da moda dizer, de paradigma. Passou a prevalecer entre nós desde a última década do século XX o paradigma dos princípios. De um lado, a nova Constituição, que se afirmava ser essencialmente principiológica. De outra banda, à mesma época passou a ser divulgado entre nós o Taking rights seriously, de Dworkin, introduzindo indagações e provocando pesquisas. $\mathrm{O}$ direito deixou de ser concebido como um 'sistema de normas' - vale dizer, de regras -, passando a ser visualizado como um sistema de princípios" (Por que tenho medo dos juízes, p. 97).

${ }^{136}$ Vale trazer a crítica consciente de EROS GRAU: "Estranhas e sinuosas vias são trilhadas nessa quase inconsciente procura de ius onde não há senão lex. [...] A racionalidade formal do direito moderno, direito positivo, direito posto pelo Estado, não pode - por certo não é fácil dizê-lo; dizê-lo exige serenidade - ser substituída por uma racionalidade de conteúdo que, fatal e irremediavelmente, será resolvida, no bojo da díade violência/direito, pelo primado do primeiro termo"(ob. cit., p. 18).
} 
que uma simples questão de hierarquia ou de economia (de tempo e de dinheiro ${ }^{137}$ ), é salutar para que o sistema jurídico receba de volta a objetividade e a segurança que a lei, ainda que a duras penas, tentava manter ${ }^{138}$.

\subsection{Noção de precedente}

Fixado que as decisões judiciais são formas de expressão do Direito, ou seja, delas brotam normas de eficácia variável a depender do sistema jurídico e mesmo dentro de um mesmo sistema, importa definir quais dessas decisões judiciais, que têm seu cumprimento controlado por meio de reclamação prevista nos artigos 102, I, $l, 103-\mathrm{A}, \S^{\circ}$. $^{\circ}$, e 105, I, $f$, da Constituição Federal de 1988, serão objeto do presente estudo. Portanto, primeiro é necessário definir a que precedentes nos referimos, ou seja, quais hipóteses de cabimento da reclamação serão estudadas aqui.

A utilização crescente do vocábulo no direito brasileiro, a nosso ver, expressa muito mais a tentativa de sintetizar as várias formas de expressão da função primordial do Poder Judiciário - jurisdição - do que uma suposta influência do sistema da common law. Embora não se ignore a expressão binding precedents do direito norte-americano, a palavra ganhou força no Brasil no afã de conglobar fenômenos que o legislador processual passou a tratar nas últimas décadas sem muito critério.

Assim, no Brasil, a palavra "precedentes", muito utilizada na expressão "valorização dos precedentes", veio aglutinar vários fenômenos correlatos, como "jurisprudência dominante" (arts. 120, parágrafo único, 544 e 557 do CPC), "jurisprudência” (art. 541 do CPC), "enunciado de súmula vinculante" (art. 3. ${ }^{\circ}$ Lei Federal 11.417/2006), "reiteradas decisões" (art. 2. ${ }^{\circ}$ da Lei Federal 11.417/2006), "casos idênticos" (art. 285-A do CPC) etc. $^{139}$.

\footnotetext{
${ }^{137} \mathrm{Na}$ medida em que homenageia a previsibilidade, inibindo, assim, demandas ajuizadas sob o manto da regra "se colar colou", e promovendo a segurança dos negócios, tão cara à economia (cf. MARINONI, Precedentes obrigatórios, p. 178-188).

${ }^{138}$ EROS GRAU, ao distinguir discricionariedade e interpretação ressalta que "[a] abertura dos textos de direito, embora suficiente para permitir que o direito permaneça ao serviço da realidade, não é absoluta. Qualquer intérprete estará, sempre, permanentemente por eles atado, retido" (ob. cit., p. 89). Mais adiante: "As regras de ordinário chamadas princípios gerais de direito não constituem criação jurisprudencial, por um lado, nem preexistem, por outro, externamente ao ordenamento" (ob. cit., p. 101).

${ }^{139}$ Nota-se, portanto, uma íntima relação entre a valorização da jurisprudência e a ampliação dos poderes dos relatores nos tribunais, como bem apontou BARBOSA MOREIRA (Súmula, jurisprudência, precedente: uma escalada e seus riscos, in: Temas de direito processual, nona série, p. 301). O enfoque parece nítido: acelerar
} 
De início, é necessário impor que nenhum desses fenômenos elencados acima se assemelha ao que ocorre no sistema anglo-saxão. Nesse sistema, o valor dado às decisões judiciais é outro, bem diverso do que lhe dão os sistemas de tradição romano-germânica, como é o caso do Brasil. Mais que isso, a eficácia da regra extraível da decisão judicial é distinta nos dois sistemas.

Aqui, decisões isoladas podem no máximo ser citadas pela parte interessada a título de exemplo persuasivo, pois, salvo casos excepcionais ${ }^{140}$, uma única decisão judicial não tem o condão de se irradiar, como norma, para além do processo em que foi proferida ${ }^{141}$. Dessa premissa resulta o fato de não termos o hábito nem a técnica de extrair das decisões judiciais a chamada ratio decidendi ${ }^{142}$, ou seja, a verdadeira norma que a decisão expõe a partir dos fatos e do direito que foi debatido no processo, e que não se confunde com o dispositivo da sentença ${ }^{143}$. Não é raro vermos petições em que a parte cita trecho de determinado julgado que veicula argumentação formulada por mera retórica, ou seja, algo que o julgador falou ou mencionou como obiter dicta ${ }^{144}$.

julgamentos, tornando desnecessária a decisão do colegiado, que depende, em regra (ressalvados os julgamentos virtuais, ainda em estágio embrionário), da reunião em sessão.

${ }^{140}$ Falamos exatamente, como se verá, dos casos que serão objeto do presente estudo, ou seja, daquelas decisões judiciais das quais, por serem dotadas de efeito vinculante, extrai-se norma jurídica geral e de aplicação obrigatória para casos semelhantes.

${ }^{141}$ Não estamos falando, aqui, da eficácia erga omnes ou extra partes comuns ao processo coletivo (tutela coletiva de direitos e tutela de direitos coletivos). A eficácia do comando da sentença ou do acórdão não tem a ver, necessária e obrigatoriamente, com sua qualidade de servir de modelo, de regra geral.

${ }^{142}$ No Direito Norte-americano, chama-se holding, ou seja, a regra que constitui um princípio geral a ser aplicado a casos futuros; sua análise engloba os fatos materiais debatidos, a motivação e a decisão propriamente dita. Segundo a doutrina, é necessário ir além de uma opinião judicial isolada (monocrática), para verificar como ela é compreendida, considerando também o histórico de outras decisões anteriores relacionadas À atual e os princípios gerais. Disso decorre que "o alcance preciso do holding pode não ficar claro até que tenha sido interpretado e aplicado em casos subsequentes" (TONI M. FINE, Introdução ao sistema jurídico anglo-americano, p. 72 a 75). Tucci propõe uma fórmula para descobrir a ratio: "Para a correta inferência da ratio decidendi, propõe-se uma operação mental, mediante a qual, invertendo-se o teor do núcleo decisório, se indaga se a conclusão permaneceria a mesma, se o juiz tivesse acolhido a regra invertida. Se a decisão ficar mantida, então a tese originária não pode ser considerada ratio decidendi; caso contrário, a resposta será positiva" (Precedente judicial como fonte do direito, p. 177).

${ }^{143}$ MARINOni, Precedentes obrigatórios, p. 221 e ss. CAIO MÁRCIO GUTTERRES TARANTO aponta que, no Brasil, estamos aprendendo a extrair a ratio decidendi das decisões para o fim de identificar a semelhança entre matérias e entre controvérsias (arts. 543-A, § 5. ${ }^{\circ}$, e 543-B, do CPC), mas ressalta que "a linguagem em que nossos precedentes são expressos faz com que a norma que deles emana seja aplicada, a priori, por dedução/subsunção, ao contrário da experiência do common law, em que os precedentes são aplicados por indução" (Precedente judicial: autoridade e aplicação na jurisdição constitucional, p. 15-17).

${ }^{144}$ Todo precedente contém, além do seu core, ou seja, sua ratio decidendi, e elementos outros que não foram significantes e indispensáveis à formulação da regra; estes elementos compõe o chamado obiter dicta, tudo o quanto é dispensável e irrelevante para o julgamento e foi dito por mera questão retórica. 
É que a definição da ratio de uma decisão sempre irá depender de sua aplicação futura, ou seja, de como o precedente é concebido como tal pelo órgão que terá de decidir o novo caso ${ }^{145}$. E esse exercício pressupõe uma necessidade do sistema de se valer do precedente para o julgamento do caso futuro, ou seja, pressupõe um respeito derivado da obrigatoriedade de que a ratio decidendi fixada no precedente seja aplicada em todos os demais casos idênticos. Essa vinculação é intrínseca à common law e decorre do princípio do stare decisis, que é a redução da expressão latina stare decisis et quieta non movere ${ }^{146} \mathrm{e}$ resume a preocupação daquele sistema com a estabilidade do Direito e com a segurança jurídica, valores caríssimos a um povo que não conhecia a lei escrita.

Além disso, para atribuir efeitos extra partes a uma decisão judicial, ou melhor, a uma dada interpretação jurídica, costuma-se exigir a sua reiteração ${ }^{147}$. Não por outra razão valorizamos tanto as chamadas súmulas de jurisprudência; elas representam - em tese $\mathrm{e}^{148}$

\footnotetext{
${ }^{145}$ HeRMES ZANETTI JR., $O$ valor vinculante dos precedentes, p. 325.

${ }^{146}$ Que se traduz em "conservam-se as decisões dos casos passados" (CRUZ E TUCCI, Precedente judicial como fonte do direito, p. 160). Consoante explica a doutrina, essa regra foi aplicada fiel e seriamente na Inglaterra até 1966, quando, The Lord Chancellor fez uma declaração no sentido de que a Casa dos Lordes passaria a afastar-se dos seus precedentes quando lhe parecesse correto, a partir da comparação dos casos, alterar a forma de aplicar o Direito. A essa técnica comparativa, dá-se o nome de distinguishing, e à mudança em si de entendimento dela decorrente, chama-se overruling (WAMBIER, Teresa Arruda Alvim.Precedentes e evolução do direito, in: Direito jurisprudencial, p. 40). Segundo Julio CuETo RUA, o stare decisis no common law norte-americano é uma norma jurídica cujo sentido axiológico se encontra nos valores ordem, segurança, paz e justiça, conforme o que os juízes de uma determinada jurisdição estão obrigados a resolver os casos pendentes mediante a aplicação das normas gerais que extraíveis de decisões passadas, proferidas por juízes da mesma jurisdição, da mesma ou superior hierarquia, em casos que oferecem certa semelhança ou analogia básica, salvo se esses precedentes representarem grosseira injustiça ou forem irracionais, ou caso tenha havido uma substancial alteração da situação social a ponto de fazer aquelas decisões anteriores perderem o sentido (El common law, p. 141-142). Para MARINONI, essas técnicas comprovam que, mais que interpretar, a Corte Inglesa raciocina por analogia (Precedentes obrigatórios, p. 223).

${ }^{147}$ Como será abordado em itens próprios, a exceção a essa regra são os julgamentos de recursos repetitivos (arts. 543-B, §4. ${ }^{\circ}$, e $543-\mathrm{C}, \S 7 .^{\circ}$, do CPC).

${ }_{148}$ Alguns verbetes, contudo, são oriundos de decisões que não tratam efetivamente do mesmo tema. Há algumas "súmulas vinculantes" que, confessadamente, não seguiram o script da lei. É o caso da chamada "súmula das algemas" (Verbete 11 da Súmula Vinculante), que trata da nulidade da prisão ou do ato processual sem que tais questões tivessem sido debatidas nos precedentes fundamentadores da regra sumular. A propósito, registre-se a manifestação do MIN. EROS GRAU durante os debates de aprovação do Verbete Vinculante 12: "[...] fico muito preocupado com o fato de da repercussão geral chegarmos diretamente à súmula. Porque há casos e casos. E hoje julgamos uma porção de recursos extraordinários, entre os quais seguramente há casos inteiramente distintos um do outro" [...]não tenho nenhum inconformismo, eu só quis registrar e lembrar. A Constituição diz '... após reiteradas decisões..."'. No caso do STJ, são conhecidas as críticas aos verbetes de n. 375 e 410, e à distorcida aplicação do verbete 214. Curioso mesmo é o caso da súmula 410. Um dos precedentes originários, motivadores de sua elaboração - o AgRg no Ag. 1.046.050/RS, rel. Min. Fernando GonÇALVES, 4. ${ }^{a}$ T., j. 06/11/2008, DJe 24/11/2008 - cita o REsp 692.386/PB (rel. Min. LuIZ FuX, j. 11/10/2005, DJe 24/10/2005), em cujo corpo, todavia, nada se fala sobre a questão que é o mote da citação, qual seja a necessidade de intimação pessoal do devedor como condição de exigibilidade das astreintes, que consta apenas na ementa: "as conseqüências cíveis e penais do descumprimento das decisões mandamentais exigem segurança na comunicação da mesma, tornando imperiosa a necessidade de intimação pessoal".
} 
a sistematização de dezenas de decisões judiciais dadas em um mesmo sentido, tratando de uma mesma questão jurídica. Em outras palavras, é da tradição de nosso sistema exigir reiteração como condição para atribuir validade e eficácia geral às decisões judiciais ${ }^{149}$.

Na common law, o direito é extraível das decisões judiciais; elas são o veículo de transmissão e transformação das regras jurídicas. Difícil, portanto, para quem labora pelo método subsuntivo, segundo o qual o aplicador do direito que trabalha com três elementos ontologicamente distintos - normas, fatos e decisões - acostumar-se a trabalhar com apenas dois - fatos e decisões ${ }^{150}$. Em outras palavras, o jurista dacommon law é educado a buscar nas decisões precedentes já tomadas em casos análogos o direito a ser aplicado nos casos futuros. O jurista de tradição romano-germânica busca a regra geral na lei em primeiro lugar, seu norte é a lei; o direito posto é a lei. As decisões judiciais são um segundo plano de análise ${ }^{151}$.

\footnotetext{
149 Tanto o art. 2. ${ }^{\circ}$ da Lei Federal 11.417/2006, ao exigir "reiteradas decisões", quanto o artigo 102 do RISTF, ao mencionar "jurisprudência assentada pelo Tribunal", parecem cobrar essa reiteração. Por seu turno, embora o RISTJ dispense a reiteração, exige julgado das Seções ou da Corte Especial e, em caso de não unanimidade, pelo menos, dois acórdãos no mesmo sentido, conforme art. 122, $\S 11^{\circ}$ : "Será objeto da súmula o julgamento tomado pelo voto da maioria absoluta dos membros que integram a Corte Especial ou cada uma das Seções, em incidente de uniformização de jurisprudência. Também poderão ser inscritos na súmula os enunciados correspondentes às decisões firmadas por unanimidade dos membros componentes da Corte Especial ou da Seção, em um caso, ou por maioria absoluta em pelo menos dois julgamentos concordantes".

${ }^{150}$ Ao tratar das massime da jurisprudência da Corte de Cassação Italiana, TARUFFO aponta uma característica primordial do common law, no qual os fatos analisados no precedente são indissociáveis da regra jurídica aplicada, de modo que não faz sentido a separação da regra, como se dá na Itália e no Brasil, com a criação das súmulasde súmula: "[...] di regola i testi che costituiscono la nostra giurisprudenza non includono i fatti che sono stati oggetto di decisione, sicché l'applicazione della regola formulata in una decisione precedente non si fonda sull'analogia dei fatti, ma sulla sussunzione della fattispecie successiva in una regola generale" (Precedente i giurisprudenza, p. 16). É que a criação dessas súmulas parte da premissa equivocada de que a aplicação da tese nelas espelhada dispensaria a conferência dos fatos que foram debatidos nos processos cujas soluções serviram de base para sua edição. Na verdade, a norma jurídica extraída dos julgados precedentes e colmatada na súmula é indissociável dos fatos que serviram de estofo àqueles julgados. Tentar aplicar súmulas desconsiderando sua origem é um dos maiores equívocos que pode cometer o intérprete e, com muita probabilidade, servirá mais para fomentar a divergência jurisprudencial que sua uniformização.

${ }^{151} \mathrm{O}$ artigo 4. ${ }^{\circ}$ da Lei de Introdução às normas do Direito Brasileiro determina que, "quando a lei for omissa, o juiz decidirá o caso de acordo com a analogia, os costumes e os princípios gerais de direito". Vale, ainda, destacar que o Projeto de novo Código de Processo Civil aprovado no Senado (PLS 166/2010) previa, em seu artigo $6 .^{\circ}$, que, "ao aplicar a lei, o juiz atenderá aos fins sociais e às exigências do bem comum, observando sempre os princípios da dignidade da pessoa humana, da razoabilidade, da legalidade, da impessoalidade, da moralidade, da publicidade e da eficiência". Esse dispositivo foi renumerado e alterado pela Câmara dos Deputados; agora, está no artigo $8 .^{\circ}$ do PL 8.046/2010 que, "ao aplicar o ordenamento jurídico, o juiz atenderá aos fins sociais e às exigências do bem comum, resguardando e promovendo a dignidade da pessoa humana e observando a proporcionalidade, a razoabilidade, a legalidade, a publicidade e a eficiência". A questão é saber se a alteração promovida realmente alcança o desiderato de ampliar o espectro das normas a serem aplicadas pelo juiz, em especial para abarcar os precedentes. Lembre-se, ainda, que o artigo 119 do PLS previa que "o juiz não se exime de decidir alegando lacuna ou obscuridade do ordenamento jurídico, cabendo-lhe, no julgamento, aplicar os princípios constitucionais, as regras legais e os princípios gerais de
} 
Inegável tem sido a aproximação dos sistemas, em muito devida a uma crise da legalidade e da própria noção de soberania vividas nos Estados Constitucionais modernos, como já mencionado acima. Segundo Thomas da Rosa de Bustamante, “de todas as modificações que surgem no Estado Constitucional, a que mais chama a atenção é uma modificação no modo de construir as normas jurídicas”. Com isso, o Direito passa a ser visto "não apenas como um conjunto de regras [...] mas como um sistema de regras e princípios", sendo que estes últimos não trazem determinações sobre o "comportamento a ser seguido, mas estabelecem um estado ideal de coisas que deve ser alcançado na máxima medida possível"152. Na verdade, segundo o autor, a assemelhação dos sistemas decorre da crise do positivismo jurídico que lhes é comum e visa a alcançar um equilíbrio ideal entre razão e autoridade ${ }^{153}$.

Por sua vez, respondendo negativamente à indagação "em direção ao common law?",TERESA ARRUDA ALVIM WAMBIER compara os sistemas para concluir que, enquanto o common law se caracteriza pelo fato de o direito nascer nos tribunais originariamente "as normas são criadas em função da oportunidade fornecida pelo caso concreto" -, no civil law, nós optamos por prestigiar a noção de sistema, sendo que o Poder Judiciário "decide com base num conjunto de normas escritas, preexistentes, pensadas para serem um sistema - coerente, organizado".

No common law, interessa notar que a vinculação dos precedentes (casos julgados) veio com o tempo, a partir de quando uma decisão de um caso era tida como aplicação do direito costumeiro (que diz com os "costumes gerais, geralmente observados"), até o momento em que as próprias decisões passaram a ser consideradas direito, ou seja, dos

direito, e, se for o caso, valer-se da analogia e dos costumes". Ao comentar esse artigo projetado, FREDIE DIDIER JR. sugeria que o texto fosse eliminado, por ser desnecessário e capaz de gerar incompreensões (A teoria dos princípios e o projeto de novo CPC, p. 148). E, de fato, essa redação foi alterada pelo PL da Câmara, que prevê, agora no artigo 140, o texto sugerido por DIDIER: "o juiz não se exime de decidir sob alegação de lacuna ou obscuridade do ordenamento jurídico", norma que apenas vem consagrar a vedação do non liquet (cf. SCARPInella BuEno, Projetos de novo Código de Processo Civil, p. 93).

${ }^{152}$ Teoria do precedente judicial, p. 116. Segundo o autor, "quando o Direito passa a ser construído e comunicado por meio de princípios" a diferença entre os sistemas jurídicos praticamente desaparece, pois "o processo de concretização de princípios - que envolve a resolução de colisões de direitos fundamentais e a densificação do seu conteúdo por meio de regras adscritas dos princípios em cada caso concreto - é rigorosamente o mesmo nas duas grandes tradições jurídicas ocidentais" (idem, ibidem).

${ }^{153}$ Segundo Bustamante, "a justificação do Direito como prática social e a justificação das decisões particulares tomadas com base no Direito não podem prescindir de uma metodologia, um processo racional para conciliar essa tensão entre ratio e auctoritas" (ob. cit., p. 119). Como realça EROS GRAU, "dizer 'juízo não de legalidade' é dizer 'juízo de valor que exclui a legalidade"', de modo que, a nosso ver, mais que uma crise do positivismo, o "principiologismo" trouxe a crise da legalidade (ob. cit., p. 116). 
princípios aplicados nascia o direito aplicável. Assim foi que se desenvolveu a confiança nos precedentes e o método correto e próprio de argumentação a partir dos precedentes ${ }^{154}$.

Nada obstante essa pretensa aproximação de sistemas, a verdade é que a diferença histórico-cultural permanece, a exigir mecanismos voltados a reduzi-la que dependem, naturalmente, de previsão legal. Ao tratar da força vinculante dos precedentes dos tribunais constitucionais, ANDRÉ RAMOS TAVARES faz interessante apontamento a respeito dos países de forte tradição de Direito legislado, para afirmar que, nesses casos,

"o precedente não é fruto de uma longa tradição, mas, sim, de normas constitucionais e/ou legais expressas que o criam, pensadas a cada momento, em forte variação conforme as necessidades históricas da sociedade e o nível de discussão e aprimoramento acerca do papel político da Justiça Constitucional e do sentido de Estado Constitucional de Direito" $" 155$.

Em decorrência disso, por mais contraditório que possa parecer, no Brasil, quando tratamos da obrigatoriedade dos precedentes, estamos falando antes de uma eficácia atribuída pela lei, do que, propriamente, de uma força que seja imanente a essas decisões ${ }^{156}$. Ocorre que é difícil imaginar um sistema genuinamente baseado em precedentes (rectius: no respeito ao precedente judicial) quando a sua força segue carecendo da prévia existência da autorização do direito posto; e mais, quando o respeito a essa eficácia prevista na lei ainda depende de um instrumento processual voltado exclusivamente para controlá-lo.

Não é por outro motivo que MARINONI reconhece que, no sistema jurídico brasileiro,

“os precedentes não vêm sequer sendo tidos como persuasivos. Embora constitua uma patologia, os tribunais e juízes muitas vezes não se julgam obrigados a respeitar os precedentes dos Tribunais Superiores. Em alguns

\footnotetext{
${ }^{154}$ Em direção ao common law?, in: O processo em perspectiva: Jornadas Brasileiras de Direito Processual, p. 372-373. Como ensina MARINONI, o "respeito aos precedentes confere aos jurisdicionados a estabilidade de uma interpretação jurídica", diversamente do que lhes confere a coisa julgada, ao garantir a imutabilidade da decisão em si (Precedentes obrigatórios, p. 111).

${ }^{155}$ Paradigmas do judicialismo constitucional, p. 88. Como dissemos acima, no Brasil, essa constatação é válida para todas as decisões dos tribunais superiores que a lei ou a Constituição Federal tenham atribuído eficácia vinculante.

${ }^{156}$ Todavia, como lembra TERESA WAMBIER, o que vincula, de ordinário, nos países de civil law "não é um precedente, mas a jurisprudência reiterada, num certo sentido, de um Tribunal Superior”, porque, mesmo nesses países, é natural o respeito à jurisprudência firme de um Tribunal Superior. Assim, conclui a autora, "se isso acontecesse aqui, não seria nem mesmo necessária a súmula vinculante" (Em direção ao common law?, p. 377-378). Ver, tb., THIAGO ASFOR ROCHA LIMA, Precedentes judiciais civis no Brasil, p. 114, em sentido um pouco diverso, e p. 118-119.
} 
casos, nem mesmo tomam em consideração os precedentes articulados pelos advogados das partes".

Segundo o autor, a questão é de lógica do sistema, e a natureza persuasiva do precedente está intimamente ligada a todo sistema de produção de decisões judiciais, já que "o postulado de que os casos similares devem ser decididos da mesma forma (treat like cases alike) constitui um princípio universal da administração da justiça" ${ }^{157}$.

Entretanto, enquanto nos sistemas de precedentes a questão da hierarquia é até secundária $^{158}$, no Brasil não há tradição de respeito a teses fixadas pelas instâncias superiores, e se costuma encarar o que deveria ser visto como verdadeira desobediência como se fosse uma natural divergência, que seria até salutar ao sistema. Pior que isso é verificar que nem mesmo a chamada vinculação horizontal se verifica entre nós, sendo muito comum haver divergência dentro de um mesmo colegiado, muito embora haja mecanismos processuais uniformizadores suficientes à disposição ${ }^{159}$. Mas esse desrespeito generalizado para com as teses fixadas pelos órgãos de hierarquia superior faz supor que não exista "ordem e organização na estrutura do Pode Judiciário e que todas as Cortes judiciárias desempenham a mesma função dentro do sistema de distribuição de justiça"160.

Com base no exposto, não podemos, aqui, nos referir a precedente judicial como se estivéssemos em um país de tradição anglo-saxã. No Brasil, as decisões judiciais expõem normas que, para serem vinculantes, dependem de prévia determinação legal. Por isso,

\footnotetext{
${ }^{157}$ Precedentes obrigatórios, p. 117-119.

${ }^{158}$ De acordo com CARLOS MAXIMILIANO, em um sistema de precedentes, a questão da hierarquia é secundária porque "o julgado, para constituir precedente, vale sobretudo pela motivação respectiva" (Hermenêutica e aplicação do direito, p. 152-153.

${ }^{159}$ Referimo-nos à uniformização de jurisprudência (arts. 476 a 479 do CPC) e à chamada assunção de competência (art. 555, § 1. ${ }^{\circ}$, do CPC). DANIEL MITIDIERO é contundente ao afirmar que só se pode falar em divergência quando o grau na hierarquia for o mesmo. Nos demais casos, há verdadeiramente desobediência: "uma Corte de Justiça que se afasta de um precedente que deve aplicar formulado por uma Corte Suprema não está dessa divergindo, está desobedecendo à interpretação da legislação formulada pela Corte Suprema", já que "a possibilidade de divergência pressupõe cortes que ocupem o mesmo grau de hierarquia judiciária" (p. 107-108).

${ }^{160}$ MITIDIERO, idem, ibidem. O autor diferencia experiência e precedente, explicando que "se determinado juiz está convencido - persuadido - da bondade de certa solução anterior, ao aplicá-la ele rigorosamente não está raciocinando à base do precedente. Ele está simplesmente se valendo do aprendizado oferecido por determinada experiência anterior". Por isso, para ele, "a autoridade do precedente, ao contrário do acerto da experiência, é o que efetivamente conta para justificar o dever e seguir precedentes". Todavia, como já exposto, o desenvolvimento dos sistemas de common law demonstra que essa distinção entre razão e autoridade do precedente se diluiu na História e que não seria absurdo cogitar de sua impertinência, pois o aplicador do Direito no common law passou a respeitar precedentes por necessidade, enquanto no civil law, quando há respeito, ele se dá por obrigação. Entendemos, como teremos oportunidade de expor, que um verdadeiro sistema de precedentes será tanto mais eficiente quanto mais se distanciar da vinculação pela autoridade e mais se aproximar da vinculação pela razão dos fundamentos determinantes.
} 
entre nós, precedente judicial será o que a lei quiser que seja. E nos termos que a lei regulamentar.

Em primeiro lugar, frise-se que a escolha do termo precedente se dá ante a ausência de outro que abarque todos os esses fenômenos normativos produzidos pelo STF e pelo STJ, para cuja observação estaria predisposta a reclamação constitucional. Além disso, o próprio fato de não se ter uma tradição relacionada ao conceito contribuiu para a escolha. Mas é imprescindível definir o conceito conforme será utilizado nesse trabalho, ou seja, a que fenômenos estaremos nos referindo.

Precedente, aqui, não se confunde com “jurisprudência”, pois, embora sejam fenômenos congêneres, tomando o termo no sentido técnico mais restrito, estaríamos tratando apenas da "coleção ordenada de acórdãos reiterados e consonantes, de um Tribunal ou de uma Justiça, sobre um mesmo tema"161. Outrossim, apesar de haver previsão legal de certos efeitos extra partes da chamada "jurisprudência dominante", não podemos falar, in casu, de eficácia vinculante propriamente dita, que torne possível o uso da reclamação como meio de controle ${ }^{162}$. Portanto, o conceito de precedente utilizado aqui não guardará relação de dependência com a repetição ou com uma coletividade de atos jurisdicionais uniformes ${ }^{163}$.

Por outro lado, nosso conceito de precedente abarcará as chamadas súmulas vinculantes, na exata medida em que se caracterizam por serem normas jurídicas emanadas do Supremo Tribunal Federal com força vinculante, a atrair a utilização da reclamação. Apesar de não se encaixarem perfeitamente ao conceito de precedentes, na condição de representarem a síntese dos precedentes do tribunal, compreendemo-las como uma fase

161 Cf. MANCUSO, Divergência jurisprudencial e súmula vinculante, p. 38. LIMONGI FRANÇA define a jurisprudência, enquanto costume judiciário, como um modo de decidir que "se repete com religiosa constância, anos a fio e na generalidade dos tribunais" (Hermenêutica jurídica, p. 161). Também JUANANTONIO XIOL aponta a constância e a uniformidade como características próprias da definição clássica de jurisprudência (Notas sobre la jurisprudencia, in: FERRERESE XIOL, El carácter vinculante de la jurisprudencia, p. 82).

${ }^{162}$ O Código de Processo Civil não prima pela retidão terminológica: os artigos 544, $§ 4 .^{\circ}$, II, "c", e o artigo 557, caput e $\S 1$. $^{\circ}$-A, referem-se a "jurisprudência dominante", como se a "dominância" não fosse mesmo ínsita ao conceito de jurisprudência. Por outro lado, o artigo 2. ${ }^{\circ}$ da Lei $11.417 / 2006$, poderia muito bem ter-se valido do termo "jurisprudência" para designar as "reiteradas decisões".

${ }^{163}$ MaXimiliano, Hermenêutica e aplicação do direito, p. 150-153. O autor diferencia claramente precedentes de jurisprudência, conceituando esta como o "uniforme e constante pronunciamento sobre uma questão de Direito, da pare dos tribunais", enquanto aqueles abarcariam as "deliberações das câmaras legislativas" e as "decisões isoladas dos magistrados". Segundo ele, "cada precedente judiciário é um elemento de jurisprudência, quando bem fundamentado: esta é constituída por um conjunto uniforme de precedentes" (ob. cit., p. 153, e nota 2 ao item 204). 
interna de formatação e formalização das teses. Em outras palavras, o fato de uma tese oriunda de determinado julgamento se converter em súmula não retira dela a natureza de precedente, especialmente se for agregado o efeito vinculante ${ }^{164}$. Daí porque somente as chamadas súmulas vinculantes estão abrangidas pelo conceito de precedente aqui utilizado $^{165}$.

Concluindo, somente faz sentido falar em precedente judicial se este for dotado de eficácia vinculante - seja por determinação expressa da lei, como se dá entre nós, seja em decorrência da tradição do sistema jurídico. A noção de precedente caminha inseparável da eficácia vinculante. Não é à toa, aliás, que, como já se disse, as únicas hipóteses em que a reclamação pode ser manejada por interessados alheios ao processo no qual foi prolatada a decisão violada são aquelas nas quais o paradigma é vinculante e erga omnes. Nos demais casos, estamos tratando da eficácia natural da coisa julgada, com seus limites objetivos e subjetivos, como será mencionado mais à frente.

No presente trabalho, portanto, o conceito de precedente não significará decisão judicial capaz de servir de mero exemplo para casos futuros ${ }^{166}$, pois estaríamos cuidando de conceito válido apenas em um sistema de respeito intrínseco aos precedentes. Quando muito, pareceria estarmos tratando dos precedentes persuasivos, os quais, por não serem vinculantes, não admitem a utilização da reclamação como forma de controle de sua aplicação, pelo simples fato de que sua aplicação não é obrigatória ${ }^{167}$.

\footnotetext{
${ }^{164}$ Aliás, pelo contrário, a transformação em súmula é condição para que a maioria dos precedentes do Supremo se torne vinculante atualmente. Como veremos, o instituto da súmula vinculante tornou possível a chamada objetivação do controle difuso de constitucionalidade exatamente porque agregou às decisões do Supremo em sede de controle concreto a eficácia vinculante característica do controle abstrato.

${ }_{165}$ Não se ignora que as súmulas não se enquadram no conceito técnico de decisão judicial nem tampouco no de precedente judicial, mas, como sua utilização, a nosso ver, depende do cotejo dos elementos fáticos dos precedentes (decisões) que a originaram, encaramos as súmulas como fazendo parte daqueles precedentes. No fundo, elas são o modo pelo qual o sistema jurídico brasileiro procurou organizar a jurisprudência do Supremo e, a partir dele, dos demais tribunais, pois representam a síntese das teses jurídicas fixadas ao longo do tempo. Representaram, portanto, o esforço de um sistema de direito legislado em ver respeitar os precedentes da mais alta Corte de Justiça do país, na esperança de criar um sistema orgânico, seguro e justo. Mas o tempo mostrou que não bastava expor as teses, era imprescindível também prever sua obrigatoriedade e um mecanismo de controle eficaz.

${ }^{166}$ Conceito este conhecido da doutrina (cf., RENÉ DAVID, Os grandes sistemas do direito contemporâneo, p. 441-442; CRUZ E TUCCI, Precedente judicial como fonte do direito, nota 1, p. 9-10).

${ }^{167}$ Embora exista muita torcida e várias razões a justificar essa evolução, ainda não chegamos - se é que chegaremos - a um sistema em que a obrigatoriedade seja equivalente de persuasão, não havendo distinção entre ambas do ponto de vista do aplicador do direito. Por todos, MARINONI afirma que "uma simples decisão tomada pelo Pleno do Supremo Tribunal Federal, não importa a qualidade da maioria obtida, não pode deixar de vincular o próprio Tribunal e os demais tribunais e juízes. Não há razão lógica para se exigirem decisões reiteradas, a menos que se parta da premissa de que o Supremo Tribunal Federal não se importa com a força
} 
Quando nos referimos a precedentes e à sua aplicação, queremos dizer que trataremos da reclamação constitucional enquanto meio processual de fazer valer a força das decisões do Supremo Tribunal Federal e do Superior Tribunal de Justiça que, por expressa previsão legal, surtem efeitos para além do processo em que foram proferidos, adquirindo determinado valor normativo geral. Enfim, para fins desse estudo, precedente é o ato jurídico emanado do Supremo Tribunal Federal ou do Superior Tribunal de Justiça que expresse uma norma jurídica dotada de eficácia erga omnes e efeito vinculante, cuja obediência possa ser controlada via reclamação ${ }^{168}$.

\subsection{Eficácia das decisões do STF e do STJ}

Definido que o conceito de precedente está ligado à eficácia vinculante das decisões, para se compreenderem as hipóteses de cabimento da reclamação destinada a garantir sua autoridade, é imperioso saber quais decisões do STF e do STJ são dotadas dessa carga máxima de vinculação capaz de tornar obrigatórias, para todo o Poder Judiciário e demais órgãos públicos, as teses nelas expostas. Em outras palavras, é imprescindível saber em que medida e circunstâncias esses tribunais produzem normas jurídicas válidas e obrigatórias para todos, independentemente da participação direta no processo em que foram produzidas ${ }^{169}$.

de cada uma das suas decisões e supõe não ter responsabilidade pelos casos futuros" (Precedentes obrigatórios, p. 79). O autor, contudo, está falando de persuasão, não de obrigatoriedade. No sistema processual brasileiro, ainda que não se possa falar que as súmulas do STJ são vinculantes, também não é verdadeiro afirmar que sejam meramente persuasivas, já que, por exemplo, permitem a barragem de uma apelação (art. 518, § $1 .^{\circ}$, do CPC).

${ }^{168}$ CAIO MÁRCIO GUTTERRES TARANTO utiliza conceito mais amplo, que não considera a vinculação obrigatória. Para esse autor, precedente é o "instrumento mediante o qual o Poder Judiciário, como instituição e no exercício da Jurisdição Constitucional, edita normas jurídicas a serem aplicadas em decisões posteriores, atribuindo-lhes racionalidade na medida em que o julgador expressa as razões de decidir" (Precedente judicial: autoridade e aplicação na jurisdição constitucional, p. 8). Também nesse conceito é possível alocar as súmulas de jurisprudência, embora, tecnicamente, como já dito, elas sejam a síntese dos precedentes que definiram a ratio decidendi nelas expressa - consignado que, para nós, as súmulasnão podem ser analisadas e aplicadas sem que se leve em consideração os julgados que lhes deram origem; por isso, e só por isso, é possível desvendar nelas uma verdadeira ratio decidendi.

${ }^{169}$ Importa, também, saber como se dá essa vinculação, ou seja, como se devem aplicar as normas produzidas por esses Tribunais. Com efeito, saber, por exemplo, se a motivação do acórdão, ou seja, se as razões que embasaram a solução dada quanto à constitucionalidade de determinado ato normativo são dotadas ou não de efeito vinculante e eficácia erga omnes é fundamental para se decidir a respeito do cabimento da reclamação ou, senão, ao menos, da legitimidade para propô-la. Nesse sentido, atribui-se ao efeito vinculante estabelecido na Constituição Federal de 1988, a aceitação, pelo Supremo, da ampliação do rol de legitimados para a propositura da reclamação (PIGNATARI, Efeitos processuais no controle judicial de constitucionalidade, p. 279). Do mesmo modo, conforme se verá mais detidamente à frente, no âmbito dos Juizados Especiais, define-se a possibilidade ou não de se ajuizar reclamação a partir do espectro de eficácia 
Nos sistemas como o brasileiro, valorizar uma decisão judicial é dotá-la de força suficiente para se tornar precedente; e dar a esses precedentes força para se tornarem obrigatórios. Por isso, entendemos interessante desenhar a linha evolutiva da valorização da jurisprudência no Brasil, desde a época colonial, em que vigoravam os assentos da Casa de Suplicação de Portugal, até os dias de hoje, com a súmula vinculante e demais espécies de precedentes obrigatórios já projetados, a comprovar uma nítida tendência de ampliação da eficácia das decisões judiciais.

Como se sabe, até meados do século XIX, éramos guiados pelas Ordenações do Reino Português. Somente em 1850, com o Regulamento 737, passamos a ter leis próprias em matéria de organização judiciária e processo civil, mas nada foi dito a respeito do preenchimento das lacunas da lei ou da solução de divergências interpretativas com base nos precedentes judiciais. Esse tema veio a lume com o Decreto 2.684, de 23 de outubro de 1875, que, além de incorporar os assentos preexistentes ao ordenamento brasileiro, permitiu, em seu artigo $2 .^{\circ}$ que o Supremo Tribunal de Justiça emitisse assentos ${ }^{170}$ com eficácia vinculante "para a inteligência das leis civis, comerciais e criminais, quando na execução delas ocorrerem dúvidas manifestadas por julgamentos divergentes havidos no mesmo Tribunal, Relações e Juízos de primeira instância"171.

Vale lembrar que a questão dos assentos está ligada, de um lado, à organização política do Estado monárquico da época e, de outro, às formas de expressão e de integração das normas jurídicas que vigoravam naquele período. Fundamental ter em mente como era exercido o poder e como eram interpretadas e aplicadas as leis, não olvidando que as decisões dos tribunais eram tidas por "interpretação autêntica"172.

da decisão do Superior Tribunal de Justiça, cuja jurisprudência somente admite serem utilizados como paradigmas de confronto, ou seja, como parâmetro descumprido, súmulas que tratem de direito material e acórdãos proferidos em julgamento de recurso especial representativo da controvérsia, pelo rito dos recursos repetitivos (STJ, 2. ${ }^{a}$ S., Rcl. 16.644, rel. MiN. SidNEI BENETTI, v. u., j. 28/05/2014, DJe 02/06/2014)

170 O termo "assento", antes mesmo de conotar um valor de precedente com força de lei, era usado nas Ordenações com sentido de registro escrito. Assentar significa registrar, por escrito, escriturar. A propósito: “Assentar. vb. 'por sobre', 'apor, anotar, sentar'/XIII, asseentar/XIII” (ANTÔNIO GERALDODACUNHA, Dicionário etimológico da língua portuguesa, 3. ed.. Rio de Janeiro: Lexikon, 2007). Foi com o reforço da previsão do Livro V, Tít. 58, §1. ${ }^{\circ}$, das Ordenações Manuelinas, é que os assentos viriam, aos poucos, adquirindo o sentido de decisões que resolviam dúvidas interpretativas das leis do reino, ou seja, de fonte do direito.

${ }^{171}$ CRUZ E TUCCI, Precedente judicial como fonte do direito, p. 233 e ss.

${ }^{172}$ CASTANHEIRA NEVES, após mostrar que, na história, já se considerou autêntica a intepretação jurisprudencial, a feita pelos doutrinadores e até pelos costumes, anota, entretanto, que "[o] que 
Na época do absolutismo monárquico português, a organização política era, do ponto de vista da distribuição do poder, bem diversa da que temos nos dias de hoje. Não se cogitava em separação de poderes, mas apenas em funções delegadas pelo monarca a determinados órgãos, que, em razão da participação ativa do rei quer na indicação dos seus membros quer, de fato, nas reuniões e decisões ali tomadas, não exerciam um poder de forma verdadeiramente livre ${ }^{173}$.

Para se ter a exata dimensão, as decisões a respeito da aplicação do direito eram tomadas por juízes eleitos pelas populações locais, mas os recursos eram submetidos a colegiados cujos membros eram nomeados pelo monarca, que deles podia até mesmo participar. Assim, por exemplo, a Cúria Régia era um conselho que auxiliava o rei no exercício de suas variadas atribuições, assuntos da administração, da legislação e da justiça, assim como depois ocorreu na própria Casa da Suplicação e, eventualmente, na Casa do Cível ${ }^{174}$. Era mesmo de se esperar que, com o tempo, em meio a tantas atribuições, os reis portugueses fossem delegando parcelas desse poder, não, contudo, sem se reservarem o de fonte suprema de integração das leis (Ordenações Afonsinas: 2.9.2).

Segundo TUCCI ${ }^{175}$, esse regime de assentos vigorou no Brasil até a proclamação da República, quando se introduziu o recurso extraordinário, inspirado no modelo do writ of error norte-americano, com a precípua finalidade de preservar a autoridade e a uniformidade na aplicação da Constituição e das leis federais pelo seu guardião, o Supremo Tribunal Federal. A finalidade era exatamente a de exercer o controle nomofilácico sobre a distribuição de justiça pelos órgãos jurisdicionais inferiores.

No mesmo sentido, ou seja, na tentativa de uniformizar a interpretação e a aplicação do direito pátrio, o Decreto 16.273/1923 criou o mecanismo do prejulgado, pelo qual a decisão sobre a questão controvertida no âmbito de órgãos fracionários do tribunal era

fundamentalmente caracteriza hoje a interpretação autêntica, o que exprime seu núcleo essencial é tratar-se nela de uma interpretação fixada imperativamente por uma norma jurídica - por via normativa abstracta, ou por uma fonte do direito de carácter normativo-prescritivo" ( $O$ instituto dos "assentos" e a função jurídica dos Supremos Tribunais, p. 337).

${ }^{173}$ AZEVEDO \& CRUZ E TUCCI, ob. cit., p. 164.

${ }^{174}$ Como pondera CASTANHEIRA NEVES, "parelhando as versões antiga e recente do instituto dos 'assentos' no Direito Lusitano, aquela se integrava a sistema de direito com uma índole fundamentalmente diferente da que corresponde ao atual, e ao serviço desse sistema obtém aí uma justificação, pois que surgiu na linha de uma evolução, só verificável no ancien régime, dos indistintos poderes legislativo e judicial do soberano assistido pela sua cúria. Em outras palavras, o assento medieval pertenceu a universo jurídico bem distinto do atual" (ob. cit., p. 7-9).

${ }^{175}$ Precedente judicial como fonte do direito, p. 234 e 237. 
submetida à apreciação do plenário. O artigo $103, \S 1^{\circ}$, desse decreto dispunha que a decisão tomada no prejulgado era obrigatória para o caso concreto e "norma aconselhável para os casos futuros, salvo relevantes motivos de direito, que justifiquem renovar-se idêntico procedimento de instalação das câmaras reunidas". Ou seja, não havia eficácia vinculante.

Embora, na origem, restrito à Corte de Apelação do então Distrito Federal, logo o instrumento foi sendo incorporado às legislações estaduais, até que a Lei 319/1936 adotou essa técnica processual para vigorar em todo o país, "visando a obviar os males da contradição entre julgados no âmbito de todas as cortes de justiça brasileiras”. Para TUCCI, sob a égide dessa lei, “o prejulgado possuía eficácia vinculante intra muros, e, portanto, horizontal, porque, a teor do artigo $1 .^{\circ}$, letra $b$, se porventura uma das turmas contrariasse a regra jurídica antes fixada pelo tribunal pleno, era cabível, contra o acórdão, recurso de revista" ${ }^{176}$.

BARbosa MOREIRA afirma haver dois tipos básicos de expedientes, tecnicamente bem distintos, que costumam ser usados pela lei para uniformizar a jurisprudência: um destinado a prevenir, outro a corrigir a desarmonia entre teses jurídicas. Com o primeiro tipo, busca-se a fixação prévia da tese, em ordem a preexcluir o risco de que, no julgamento que se vai seguir, venha a configurar-se o dissídio jurisprudencial. Com o segundo, dissídio já configurado, abre-se uma via para a revisão do julgamento, na perspectiva da solução da quaestio iuris. O prejulgado era exemplo de meio preventivo, enquanto o recurso extraordinário incorporava a forma corretiva. Segundo o autor, contudo, o alcance prático de ambos tem sofrido limitações muito sensíveis, baseado na repulsa que a tradição pátria tem para com o sistema de precedentes vinculativos. Por isso,

“a fixação prévia da tese jurídica normalmente só predetermina a decisão que se profira in specie, mas revela-se impotente para evitar que, noutro caso, a idênticos esquemas de fato se venha a aplicar tese diversa. E, diante de divergência já ocorrida, o máximo que se pode fazer é corrigir a decisão sob exame" ${ }^{, 177}$.

O Código de Processo Civil de 1939, que é marco da unificação do processo civil no Brasil, conservou, em seu artigo 861, o instituto do prejulgado, mas não manteve a possibilidade de se recorrer de revista contra a decisão da Turma que contrariasse

${ }^{176}$ Ob. cit., p. 239. BARBOSA MOREIRA, por sua vez, afirma que a doutrina prevalecente à época limitava a eficácia vinculativa ao caso concreto (Comentários ao Código de Processo Civil, p. 27).

${ }^{177}$ Comentários ao Código de Processo Civil, p. 5-6. 
precedente do plenário, o que excluiu de vez qualquer tentativa de vislumbrar efeitos vinculantes na tese fixada nessa sede.

Também já se afirmou que o antecedente histórico que mais se aproxima do que hoje conhecemos como efeito vinculante está na previsão contida no $§ 2 .^{\circ}$ do artigo 59 da Constituição Federal de 1891, segundo a qual, nos casos em que houver de aplicar leis dos Estados, a justiça federal deveria "consultar" a jurisprudência dos tribunais locais, e, viceversa, as justiças dos Estados consultariam a jurisprudência dos tribunais federais, quando fossem interpretar as leis da União. No entanto, essa consulta acabou significando apenas o que em vernáculo significa, ou seja, não importava, ainda, qualquer vinculação da interpretação de uma justiça à outra. Isso só veio a ocorrer com o Decreto 23.055, de 9 de agosto de 1933, cujo artigo 1. ${ }^{\circ}$ preceituava: “As justiças dos Estados, do Distrito Federal e do Território do Acre devem interpretar as leis da União de acordo com a jurisprudência do Supremo Tribunal Federal" ${ }^{\text {178. }}$.

Depois disso, a Emenda Constitucional de 28 de agosto de 1963 permitiu que o Regimento Interno do STF instituísse a chamada Súmula da Jurisprudência Predominante (art. 102 do RISTF), instrumento prático ainda hoje importantíssimo para viabilizar aforça persuasiva dos precedentes da Corte ${ }^{179}$.Com base na crise de autoridade por que passava $\mathrm{o}$ Supremo na época ${ }^{180}$, a doutrina afirma que "ainda que oficialmente destinada a facilitar o trabalho dos advogados e do próprio STF", a Súmula "nasce como reação da nossa Corte Suprema ao processo de debilitação que estava sofrendo".

Mas além de implicar enorme reforço à autoridade do Supremo, atribuía-lhe poder quase legislativo e alimentava o "autoritarismo natural" de quem está em condições de

\footnotetext{
${ }^{178} \mathrm{LEAL}, O$ efeito vinculante na jurisdição constitucional, p. 131-133.

${ }^{179}$ Conta-se que os primeiros 370 verbetes foram aprovados já na sessão plenária de 13/12/1964 e passaram a ter eficácia a partir do ano seguinte (TUCCI, Precedente judicial como fonte do direito, p. 243).

${ }^{180}$ Foi nessa época, em setembro de 1963, que, nas palavras de EvANDRO LiNS E SILVA, houve um "verdadeiro sequestro" do ministro Victor Nunes Leal, após o julgamento de que foi relator e no qual o Supremo decidiu pela inelegibilidade dos sargentos. Ou seja, um juiz da Máxima Corte de Justiça do país havia sido sequestrado pela parte "desgostosa com o resultado proferido num processo". Conta, ainda, o exMinistro do Supremo que, "[a]pesar de a representação parlamentar de soldados, cabos e sargentos ser vedada pela Constituição de 1946, o sargento do Exército Antônio Garcia Filho, líder do Comando Nacional dos Sargentos, conseguiu, com base em mandado de segurança, concorrer às eleições de 1962 para a Câmara Federal pela legenda do PTB da Guanabara. Eleito, foi o único sargento que tomou posse, já que os outros sargentos eleitos tinham sido cassados pelos tribunais regionais eleitorais. Em setembro de 1963, quando o STF votou contra a elegibilidade dos sargentos, foi deflagrada a Revolta dos Sargentos de Brasília" ( $O$ salão dos passos perdidos, p. 368 e nota 3 da p. 409).
} 
dizer sempre a última palavra ${ }^{181}$. Além disso, ainda que de eficácia normativa em sentido estrito, "o ordenamento passou a conferir às súmulas de jurisprudência predominante, desde sua concepção inicial, efeitos de natureza processual" ${ }^{182}$.

Portanto, por enquanto, ainda não havia previsão de atribuição de efeito eminentemente vinculante a nenhuma decisão judicial. Mas, ao disciplinar a recém-criada representação para interpretação de lei ou de ato normativo federal ou estadual ${ }^{183}$, a qual conferiu ao Supremo o poder de impor, em processo de natureza abstrata, a interpretação a ser adotada em face de determinado texto normativo, o Regimento Interno passou a atribuir às decisões tomadas nessas representações força vinculante para todos os efeitos.

A respeito, ROGER LEAL ressalta que as divergências interpretativas deflagradas por outros órgãos jurisdicionais após a interpretação ser fixada pelo Supremo importavam "violação a literal dispositivo de lei" para efeito de cabimento de rescisória e "negativa de vigência de lei”, hipótese suficiente para a interposição, à época, de recurso extraordinário (art. 119, III, $a$, da EC 1/1969). Segundo o autor, dentre os antecedentes históricos, essa força vinculante das decisões proferidas em sede de representação interpretativa era o instituto que mais se aproximava do efeito vinculante ${ }^{184}$.

Entretanto, foi apenas com a nova ordem instaurada pela Constituição Federal de 1988, em especial após a EC 3/1993, que se passou a prever, expressamente, o efeito vinculante das decisões tomadas em sede de controle de constitucionalidade concentrado, conforme o artigo 102, $2 .^{\circ}$, segundo o qual:

"as decisões definitivas de mérito, proferidas pelo Supremo Tribunal Federal, nas ações declaratórias de constitucionalidade de lei ou ato normativo federal, produzirão eficácia contra todos e efeito vinculante,

\footnotetext{
181 À época, vigoravam o Código de Processo Civil de 1939 de a Constituição de 1946, pelos quais a uniformização de jurisprudência se realizava somente mediante recurso ou no julgamento de recursos (para tanto, serviam a revista, o prejulgado, o recurso extraordinário e os embargos de divergência), cuja admissibilidade, todavia, "não sofria outras restrições que as ditadas pelo seu próprio fim, ainda que enrijecidas pela antipatia que a revista e os embargos de divergência sempre despertaram nos julgadores". Antipatia devida à inconformidade com o dever de submeter à revisão os casos já decididos pelo mesmo Tribunal (BoTELHO DE MESQuiTA, Súmula da Jurisprudência Predominante do STF, p. 220-222).

${ }^{182}$ LEAL, $O$ efeito vinculante na jurisdição constitucional, p. 134.

${ }^{183}$ Trata-se de inovação trazida com a Emenda Constitucional 7, de 13 de abril de 1977, como parte das reformas devidas ao chamado "Pacote de Abril".

${ }^{184}$ Ob. cit., p. 136-138.
} 
relativamente aos demais órgãos do Poder Judiciário e ao Poder Executivo"

Posteriormente, a Lei 9.868/1999 estendeu essa eficácia vinculante às decisões prolatadas em sede de ação direta de inconstitucionalidade, "em relação aos órgãos do Poder Judiciário e à Administração Pública federal, estadual e municipal" (art. 28, parágrafo único). Algumas semanas após a edição dessa lei, foi promulgada a Lei 9.882/1999, que, ao disciplinar o processo da arguição de descumprimento de preceito fundamental, também às decisões tomadas nessa sede atribuiu efeito vinculante "relativamente aos demais órgãos do Poder Público" (art. 10, §3.).

O ponto máximo dessa caminhada chegou com a Emenda Constitucional 45/2004, consagradora da chamada Reforma do Poder Judiciário: ao prever a edição pelo Supremo Tribunal Federal de verbetes sumulares vinculantes, acaba por romper, em parte, "com a concepção de raiz europeia que inspira o instituto, pois, nesse particular, estende-o a decisões adotadas fora do controle abstrato de constitucionalidade"186. Além disso, alterase a redação do citado $\S 2 .^{\circ}$ do artigo 102 , para estabelecer que

"as decisões definitivas de mérito, proferidas pelo Supremo Tribunal Federal, nas ações diretas de inconstitucionalidade e nas declaratórias de constitucionalidade produzirão eficácia contra todos e efeito vinculante, relativamente aos demais órgãos do Poder Judiciário e à administração pública direta e indireta, nas esferas federal, estadual e municipal”.

Mas, do ponto de vista do sistema processual em geral, outros meios de ampliação de eficácia das decisões dos Tribunais, em especial do Supremo e do STJ, foram sendo desenhados, sem, contudo, se chegar a generalizar o efeito vinculante. A propósito, anotese que o regime original do Código de Processo Civil de 1973 previa mecanismo de uniformização dejurisprudência e de edição de súmulas (art. 479 do CPC), a evidenciar apreocupação de dar tratamento isonômico aos demais casos semelhantes ${ }^{187}$.

\footnotetext{
${ }^{185}$ Em que pese a clareza do dispositivo constitucional, vozes surgiram no sentido de que tal efeito deveria também decorrer, por lógica do sistema, das decisões tomadas em sede de ação direta de inconstitucionalidade. No julgamento da Rcl. 621/RS, DJU de 04/07/1996, o MiN. SEPÚlVEDA PERTENCE afirmou que "é mais razoável sustentar que, quando cabível em tese a ação declaratória de constitucionalidade, a mesma força vinculante haverá de ser atribuída à decisão definitiva da ação direta de inconstitucionalidade".

${ }^{186}$ LEAL, ob. cit., p. 144. O autor faz um interessante apontamento, ao lembrar que, nessa hipótese, o efeito vinculante veio dissociado da eficácia erga omnes, como se dela não dependesse.

${ }^{187}$ Cabe anotar, ainda, que o projeto Buzaid previa a volta dos assentos com força vinculante. A decisão sobre a tese jurídica tomada pela maioria absoluta dos membros efetivos do STF ou de Tribunal de Justiça seria obrigatória enquanto não modificada por outro acórdão proferido na mesma forma. BARBOSA MOREIRA lembra que "tal sistemática foi criticada em sede doutrinária, antes de mais nada, por inconstitucional". Com
} 
Logo depois, a Lei Orgânica da Magistratura - LOMAN (LC 35/1979)autorizou que, nos processos de competência do Tribunal Federal de Recursos (TFR), o relator negasse seguimento a recurso contrário a "súmula do Tribunal ou do STF" (art. 90, § 2. ${ }^{\circ}$ ), o que representou manifestação inequívoca ampliação da eficácia desses enunciados. No mesmo sentido, veio a Lei 8.038/1990, que, em seu artigo 38 autorizou o relator, no STF e no STJ, a negar seguimento a recurso contrário a "súmula do respectivo tribunal".

O movimento de ampliação da força dos precedentes (não apenas dos sumulados, mas também dos demais) foi acelerado com as reformas do Código de Processo Civil ocorridas a partir de 1994. Por exemplo, a nova redação do artigo 557 e de seus parágrafos autorizou o relator, nos tribunais, a, individualmente, negar seguimento a recursos, quando a decisão recorrida estiver adequada às súmulas ou à jurisprudência dominante do respectivo tribunal ou dos tribunais superiores; e a dar-lhes provimento, quando a decisão recorrida estiver em confronto com súmula ou jurisprudência dominante dos tribunais superiores $^{188}$. O parágrafo único do artigo 481 instituiu o sistema de vinculação dos órgãos fracionários dos tribunais aos seus próprios precedentes e, quando houver, aos do STF, nos incidentes de inconstitucionalidade ${ }^{189}$.

Em 2001, o parágrafo único do artigo 741 passou a atribuir a decisões do STF sobre a inconstitucionalidade de normas, mesmo em controle difuso, a eficácia de inibir a execução de sentenças a ele contrárias (verdadeira eficácia rescisória), o que foi reafirmado em 2005 (art. 475-L, § 1. ${ }^{\circ}$, do CPC). Ainda em 2001 foi incluído o $§ 1^{\circ}{ }^{\circ}$ no artigo 555, prevendo a chamada assunção de competência, cuja solução, feita uma interpretação sistemática do Código, deveria seguir o rito do incidente de uniformização de

isso, foi abandonada a solução dos assentos com força de lei, mas não foi suprimido o respectivo capítulo, que recebeu nova feição, inspirada justamente na Súmula da Jurisprudência Dominante do STF (in Comentários ao Código de Processo Civil, p. 7).

188 Outrossim, foi atribuída competência ao relator de agravo de instrumento em recurso especial e em recurso extraordinário para, desde logo, invocando jurisprudência ou súmula do STJ ou STF, conhecer do agravo e prover o próprio recurso especial ou o próprio recurso extraordinário (art. $544, \S \S 3 .^{\circ}$ e $4 .^{\circ}$, do CPC). Em 1998, o parágrafo único do artigo 120 do Código de Processo Civil trouxe autorização para o relator decidir de plano conflito de competência quando há "jurisprudência dominante do tribunal sobre a questão suscitada".

${ }^{189}$ Ao julgar o RE 191.896, rel. MIN. SePÚlvedA PERTENCE, j. 27.05.1997, a 1. a Turma do STF, emprestou, às declarações de inconstitucionalidade incidentais, a eficácia de quebrar a presunção de constitucionalidade das normas e, com isso, afastar a incidência da reserva de plenário estabelecida no artigo 97 da CF/1988. 
jurisprudência, ou seja, redundar na edição de súmula, a ser respeitada (ainda que sem eficácia vinculante) pelos órgãos vinculados ao tribunal (art. 479) ${ }^{190}$.

Cinco anos mais tarde, em 2006, consagrou-se a chamada súmula impeditiva de recurso, passando a ser descabida a apelação contra sentenças proferidas com base em súmulas do STF ou do STJ (art. 518, § 1. ${ }^{\circ}$,do CPC). No mesmo ano, os artigos 543-A e 543-B do Código, ao disciplinarem a "repercussão geral" para efeito de conhecimento de recursos extraordinários (art. 102, $\$ 3 .^{\circ}$, da CF/1988), reafirmaram notavelmente e deram sentido prático à força dos precedentes do STF. Em 2008, foi editada a Lei 11.672/2008, que acrescentou o art. 543-C ao CPC, instituindo, para recursos especiais repetitivos, um sistema de julgamento semelhante ao da repercussão geral. O sistema não apenas confere especial força aos precedentes do STF e do STJ, mas também institui fórmulas procedimentais para tornar concreta e objetiva a sua aplicação aos casos pendentes de julgamento.

Ainda interessa ao presente estudo lembrar que, no âmbito do microssistema dos juizados especiais, o regime de vinculação aos precedentes dos tribunais superiores vem desde a Lei 10.259/2001 (Lei dos Juizados Especiais Federais), a qual, em seu artigo 14, criou um mecanismo de "uniformização de interpretação de lei federal", de competência de um órgão de caráter nacional (a "Turma de Uniformização" - § 2. ${ }^{\circ}$ ), cujo referencial último é a observância da "súmula ou jurisprudência dominante no STJ" $\left(\S 4 .^{\circ}\right)^{191}$.

Regime muito semelhante foi estendido ao sistema dos juizados especiais dos Estados e do Distrito Federal ${ }^{192}$ pela Lei 12.153/2009 (Juizados da Fazenda Pública), a qual, em seu artigo 18, estabelece que o "pedido de uniformização de interpretação de lei quando houver divergência entre decisões proferidas por Turmas Recursais sobre questões de direito material” será julgado, em reunião conjunta das Turmas em conflito, sob a presidência de um desembargador ( $\left.\$ 1 .^{\circ}\right)$; e será julgado pelo STJ “quando as Turmas de

\footnotetext{
${ }^{190} \mathrm{Na}$ mesma época, dispensou-se o reexame necessário das sentenças que adotam jurisprudência do plenário do STF ou súmula do tribunal superior competente (art. 475, § 3. ${ }^{\circ}$, do CPC).

${ }^{191}$ Em caso de demandas repetitivas, instalado o incidente, ficam retidos os demais recursos $\left(\S \S 5 .^{\circ}\right.$ a $\left.8 .^{\circ}\right)$, os quais, após a definição da interpretação pelo órgão superior, serão julgados nas Turmas Recursais, que poderão "exercer o juízo de retratação ou declará-los prejudicados" (§ 9. $\left.{ }^{\circ}\right)$. Havendo recurso extraordinário, nos Juizados, ele será processado e julgado pelo mesmo sistema dos $\S 4^{\circ}{ }^{\circ}$ a $9 .^{\circ}$ do artigo 14 (art. 15), de modo que o precedente assim formado terá a força de impor julgamento idêntico aos demais recursos sobre a matéria decidida.

${ }^{192}$ Que inclui, sem dúvida, todos os órgãos dos Juizados, e não apenas os Juizados da Fazenda Pública - art. 1. ${ }^{\circ}$, parágrafo único.
} 
diferentes Estados derem a lei federal interpretações divergentes, ou quando a decisão proferida estiver em contrariedade com súmula do Superior Tribunal de Justiça" (art. 18, §

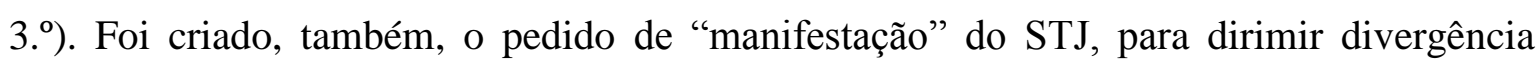
"quando a orientação acolhida pelas Turmas de Uniformização (...) contrariar súmula do Superior Tribunal de Justiça” (art. 19) ${ }^{193}$.

Por fim, vale mencionar as alterações propostas no Projeto de novo Código de Processo Civil ${ }^{194}$, que, nos artigos 924 e 925, constantes do Capítulo I do Título I ("Da Ordem dos Processos e dos Processos de Competência Originária dos Tribunais") do Livro III (“Dos Processos nos Tribunais e dos Meios de Impugnação das Decisões Judiciais”), procura criar um sistema de respeito a precedentes no País, ainda que de forma tímida.

O artigo924 determina que os tribunais devem uniformizar sua jurisprudência e mantê-la estável, íntegra e coerente. Seu $§ 10^{\circ}$ estabelece que editarão enunciados de súmula correspondentes a sua jurisprudência dominante, na forma e segundo os pressupostos fixados no regimento interno, enquanto o $\S 2 .^{\circ}$ obriga-os, ao editar enunciados de súmula, a se aterem às circunstâncias fáticas dos precedentes que motivaram sua criação.

Por sua vez, segundo o artigo 925 projetado, os juízes e os tribunais deverão observar: I - as decisões do Supremo Tribunal Federal em controle concentrado de constitucionalidade; II - os enunciados de súmula vinculante; III - os acórdãos em incidente de assunção de competência ou de resolução de demandas repetitivas e em julgamento de recursos extraordinário e especial repetitivos ${ }^{195}$; IV - os enunciados das súmulas do Supremo Tribunal Federal em matéria constitucional e do Superior Tribunal de

\footnotetext{
${ }^{193}$ Nos casos do $\S 3 .^{\circ}$ do artigo 18 e do artigo 19 , em que é provocado o pronunciamento do STJ, os pedidos semelhantes ficarão retidos (art. 19, parágrafo único); publicado o acórdão do STJ, esses pedidos "serão apreciados pelas Turmas Recursais, que poderão exercer juízo de retratação ou os declararão prejudicados, se veicularem tese não acolhida pelo Superior Tribunal de Justiça" (art. 19, $\S 6^{\circ}{ }^{\circ}$ ). Quanto ao recurso extraordinário, o processo e o julgamento obedecerão a esse mesmo método (art. 15), a significar, aqui também, que o precedente repercutirá no julgamento de todos os demais recursos em tema semelhante. Registre-se que essa linha do tempo da evolução da eficácia das decisões judiciais no sistema processual brasileiro foi retirada do elucidativo voto do MIN. TEORI ZAVASCKI na Rcl. 4335/AC, rel. Min. GILMAR MENDES, j. 20/03/2014, DJe 21/10/2014, já mencionada anteriormente

${ }^{194}$ A referência é ao texto final aprovado pela Comissão Temporária do Senado (votação dia 04/12/2014), relativo ao Projeto de Lei 8.046/2010, oriundo da Câmara dos Deputados, em revisão ao PLS 166/10. A versão final, aprovada pelo Plenário do Senado, não foi publicada até a conclusão desse trabalho.

${ }^{195} \mathrm{O}$ art. 926 estabelece que: "Para os fins deste Código, considera-se julgamento de casos repetitivos a decisão proferida em: I - incidente de resolução de demandas repetitivas; II - recursos especial e extraordinário repetitivos. Parágrafo único. O julgamento de casos repetitivos tem por objeto questão de direito material ou processual".
} 
Justiça em matéria infraconstitucional; IV - a orientação do plenário ou do órgão especial aos quais estiverem vinculados. Trata-se de inegável atribuição de força vinculante a esses precedentes, que serão de observância obrigatória no âmbito do Poder Judiciário.

Os parágrafos desse artigo prosseguem regulamentando a forma de aplicação dos precedentes. $\mathrm{O} \S 10^{\circ}$ estabelece que os juízes e os tribunais observarão o disposto no artigo10 ${ }^{196}$ e no artigo 486, $\S 1 .^{{ }^{1} 197}$. O $\S 2$. $^{\circ}$ estabelece saudável mecanismo de legitimação dos precedentes, ao prever que a alteração de tese jurídica adotada em enunciado de súmula ou em julgamento de casos repetitivos poderá ser precedida de audiências públicas e da participação de pessoas, órgãos ou entidades que possam contribuir para a rediscussão da tese.

O § 3. ${ }^{\circ}$ autoriza a modulação de efeitos em nome do interesse social e da segurança jurídica: na hipótese de alteração da jurisprudência dominante do Supremo Tribunal Federal e dos tribunais superiores ou daquela oriunda de julgamento de casos repetitivos, pode haver modulação dos efeitos da alteração. O $\S 4 .^{\circ}$ também trata da necessária fundamentação adequada quando for caso de modificação de enunciado de súmula, de jurisprudência pacificada ou da tese adotada: em julgamento de casos repetitivos observará a necessidade de fundamentação adequada e específica, considerando os princípios da segurança jurídica, da proteção da confiança e da isonomia.

A fundamental publicidade a ser dada aos precedentes vem prevista no $\S 5 .^{\circ}$, que exige ainda uma organização por questão jurídica decidida e uma preferencial divulgação na rede mundial de computadores.

Em resumo, de todo esse histórico evolutivo, é possível concluir que a lei chegou a atribuir eficácia extra partes à súmula e à jurisprudência dominante do STF e do STJ, sem, contudo, prever o cabimento da reclamação como meio de controlar a obediência às teses

\footnotetext{
196 “Art. 10. O juiz não pode decidir, em grau algum de jurisdição, com base em fundamento a respeito do qual não se tenha dado às partes oportunidade de se manifestar, ainda que se trate de matéria sobre a qual deva decidir de ofício."

197 "§ $10^{\circ}$ Não se considera fundamentada qualquer decisão judicial, seja ela interlocutória, sentença ou acórdão, que: I - se limitar à indicação, à reprodução ou à paráfrase de ato normativo, sem explicar sua relação com a causa ou a questão decidida; II - empregar conceitos jurídicos indeterminados, sem explicar o motivo concreto de sua incidência no caso; III - invocar motivos que se prestariam a justificar qualquer outra decisão; IV - não enfrentar todos os argumentos deduzidos no processo capazes de, em tese, infirmar a conclusão adotada pelo julgador; $\mathrm{V}$ - se limitar a invocar precedente ou enunciado de súmula, sem identificar seus fundamentos determinantes nem demonstrar que o caso sob julgamento se ajusta àqueles fundamentos; VI - deixar de seguir enunciado de súmula, jurisprudência ou precedente invocado pela parte, sem demonstrar a existência de distinção no caso em julgamento ou a superação do entendimento."
} 
nelas fixadas. Em tese, todas essas alterações não foram capazes de tornar as decisões do STF e do STJ obrigatórias nem mesmo aos demais órgãos do Poder Judiciário, pois o sistema continua convivendo com a possibilidade de órgãos subalternos não aplicarem o entendimento desses tribunais, que somente poderão ser chamados a atuar, caso a parte interessada logre aviar os recursos extraordinários cabíveis.

Todavia, é muito importante ressaltar que o sistema convive perfeitamente com essa realidade, na qual o controle dessa eficácia "quasevinculante" se dá pela via recursal ordinária, ainda que não se trate de efeito vinculante propriamente dito. Em outras palavras, no sistema vigente, em todas essas hipóteses em que as decisões do STF e do STJ são capazes de surtir efeitos para outros processos, ou seja, em que a tese fixada pela “jurisprudência dominante” ou por súmula deva ser seguida de alguma forma, o único meio de controlar essa obediência são os recursos cabíveis ${ }^{198}$.

\subsection{Precedentes obrigatórios: o efeito vinculante}

No Brasil, como instrumento de controle de aplicação de precedentes, a reclamação depende de que tais normas sejam dotadas do chamado efeito vinculante ${ }^{199}$. Não seria demais afirmar, aliás, na linha do conceito aqui proposto, que só existe precedente judicial quando a decisão ou ato que a veicula for dotada de efeito vinculante. Caso contrário,

\footnotetext{
${ }^{198}$ E o sistema projetado do novo Código de Processo Civil parece ter mantido isso ao menos em parte, pois permite o uso da reclamação apenas nos casos de precedente fixado em sede de julgamentos repetitivos (art. 985, IV).

${ }^{199}$ Essa é a posição do STF e do STJ. Do primeiro, citam-se os seguintes julgados: RTJ 159/15, rel. MIN. SYDNEY SANCHES - RTJ 201/519, rel. MIN. AYRES BRITTO - Rcl. 3.159-AgR/SP, rel. MIN. GILMAR MENDES - Rcl. 16.551-AgR/SP, rel. MIN. TEORI ZAVASCKI; Rcl. 4.381-AgR/RJ, rel. MIN. CELSODE MELLO; Rcl. 5.335-ED/MG, rel. MIN. CEZAR PELUSO; Rcl. 17.914-AgR/MS, rel. MIN. RICARDO LEWANDOWSKI; e, mais recentemente, Rcl. 17566 AgR/SP, $1^{\text {a }}$. T., rel. MIN. CELSODE MELLO, j. 16/09/2014, DJe 20/11/2014. Deste último julgado, retira-se o seguinte trecho do voto do relator: "o Supremo Tribunal Federal tem advertido não caber reclamação quando utilizada, como no caso, para fazer prevalecer a jurisprudência desta Suprema Corte (ou para impor-lhe a observância), em situações nas quais os julgamentos do Tribunal não se revistam de eficácia vinculante, exceto se se tratar de decisão que o Supremo Tribunal Federal tenha proferido em processo subjetivo no qual haja intervindo, como sujeito processual, a própria parte reclamante, hipótese inocorrente". Do STJ, que segue a jurisprudência do STF, podem-se citar os seguintes: Rcl. 2.163/MG, Rel. MIN. ELIANA CALMON, 1. ${ }^{a}$ S., DJU de 20/11/2006; Rcl. 1.590/MS, rel. MiN. JOSÉ DELGADO, 1. a S., DJU de 25/10/2004; AgRg na Rcl. 12713/DF, 1. a S., rel. MIN. MAURO CAMPBELl MARQUES, j. 13/11/2013, DJe 20/11/2013; AgRg na Rcl. 11875/SC, 3. ${ }^{a}$ S., Ministra ALDERITA RAMOSDE OlIVEIRA (Desembargadora Convocada do TJ/PE), j. 12/06/2013, DJe 19/06/2013; Rcl. 12516/PA, 1. ${ }^{a}$ S., rel. MIN. ASSUSETE MAGALHÃES, 26/11/2014, DJe. 05/12/2014. Dessa tese decorre a limitação da legitimidade ativa, pois "quem não foi abrangido por decisão proferida em recurso extraordinário não pode utilizá-la como paradigma para fins de cabimento de reclamação" (Rcl. 6464 ED/SC, 1. ${ }^{\mathrm{a}}$ T., rel. MIN. ROBERTO BARROSO, j. 04/11/2014, DJe 19/11/2014) .
} 
estaremos no campo da mera persuasão, a qual, embora seja o espírito dos sistemas em que verdadeiramente há respeito a precedentes, em um sistema como o nosso, não é suficiente garantir a segurança e a certeza necessárias ${ }^{200}$.

Parece lógico que, em um sistema no qual se pretende instituir a cultura de respeito a precedentes - vale dizer, pretende-se obrigar à obrigatoriedade -,só exista garantia daquele respeito caso haja o correspondente dever judicial; dever este que, além de poder ser controlado, deve implicar a necessária responsabilidade em caso de descumprimento, ou seja, a possibilidade de ser exigido em caso de não ser cumprido.

Mas, ou há respeito à ratio decidendi que anima o precedente judicial, ou não há. Por isso, ao contrário do que afirma LUIZ GUILHERME MARINONI, não vislumbramos a possibilidade de graduação da intensidade desse respeito, pois não se pode confundir a graduação da eficácia das decisões judiciais com um escalonamento do seu respeito ${ }^{201}$.

Respeitar um precedente, com rigor técnico, é seguir à risca a norma nele fixada. Se ter seguido determinada norma veiculada em súmula do STF e do STJ, por exemplo, é suficiente para impedir o conhecimento da apelação interposta em sentido contrário, isso não quer dizer que houve um respeito menos forte à interpretação fixada naqueles enunciados (art. 518, § 1. ${ }^{\circ}$, do CPC). Ao contrário, significa exatamente que o sistema jurídico permite o desrespeito ao precedente, ou seja, convive com a possibilidade de uma sentença contrariar o direito já sumulado pelo STF e pelo STJ. Prova dessa deficiência do sistema é a possibilidade expressa na lei de os tribunais de segundo grau divergirem do entendimento firmado pelo STF e pelo STJ em sede de recursos repetitivos (arts. 543-B, $\S 4 .^{\circ}$, e $543-\mathrm{C}, \S 8 .^{\circ}$, do CPC).

O que se admite, portanto, é uma graduação da eficácia dos precedentes judiciais, mas não de seu respeito. Para os fins desse estudo, interessa saber quais as decisões do STF e do STJ a cujo respeito a lei obriga efetivamente, já que não vivemos em um sistema de vinculação automática dos precedentes judiciais.

Vimos que a jurisprudência dominante e as súmulas do STJ e do STF são dotadas de eficácia suficiente a permitir que o interessado se valha dos recursos previstos no sistema

\footnotetext{
${ }^{200}$ Isso não quer dizer que a simples atribuição de efeito vinculante ex lege seja capaz de obrigar a aplicação do precedente. Absolutamente. Mas, dessa atribuição decorre a consequência de se poder responsabilizar por eventual descumprimento, o que não pode ser feito nos demais casos.

${ }^{201}$ Precedentes obrigatórios, p. 110.
} 
como forma de exigir a observância das teses nelas fixadas. De fato, as hipóteses de cabimento do recurso extraordinário e do recurso especial permitem que sejam eles interpostos em caso de não observância pelos tribunais de segundo grau das teses jurídicas acolhidas pela sua jurisprudência dominante ou sintetizadas nas suas súmulas. Mas não se prevê qualquer responsabilização do órgão subalterno que deixou de seguir a interpretação dada pelo Supremo ou pelo STJ, ou seja, na prática, não há propriamente um dever de obediência.

Assim, não podemos considerar que tais fenômenos jurisprudenciais sejam exemplo de precedentes obrigatórios, pois segui-los é mera recomendação do sistema processual. Recomendação salutar, justificada, cujo atendimento significaria indiscutível evolução no sistema jurídico brasileiro, mas recomendação. Por isso é necessário divisar o que seja, de fato, obrigatório do que seja meramente persuasivo.

ROGER LEAL ensina que o chamado efeito vinculante surgiu em alguns países europeus não afeitos à prática construtivista do stare decisis, ao notarem a necessidade de reforçar a eficácia das decisões prolatadas no âmbito da jurisdição constitucional, de modo que os demais poderes do Estado, inclusive os tribunais e a administração pública, estivessem vinculados não só à parte dispositiva da sentença - o que, por si, já lhe é decorrência natural -, mas também aos motivos, princípios e interpretação que as fundamentaram, ou seja, à norma concreta exposta na decisão. Tratava-se, então, de fazer impor a ratio decidendi que se fixou na decisão vinculante ${ }^{202}$.

Mas é preciso lembrar que, em regra, toda decisão já é vinculante no que tange às próprias partes do processo, por implicação natural das funções positiva e negativa da coisa julgada material, embora seus efeitos possam atingir terceiros. Por isso, não se confunda efeito vinculante com a eficácia erga omnes, pois afirmar que uma decisão possui essa

\footnotetext{
${ }^{202}$ Efeito vinculante na jurisdição constitucional, p. 113. O autor faz questão de distinguir efeito vinculante de stare decisis, lembrando que este se constitui "instrumento erigido nos primórdios do common law de modo a atribuir alguma estabilidade na regulação das relações sociais, quando a produção legislativa era ainda escassa ou nula" (p. 127). MARINONI ressalta, contudo, que, "[a]o se falar em eficácia vinculante da fundamentação se está generalizando, de modo atécnico, a eficácia vinculante ou obrigatória atribuída, no common law, a toda e qualquer ratio decidendi", sendo óbvio que o tribunal não revela o seu entendimento apenas no dispositivo (Precedentes obrigatórios, p. 272). ElIVAL DA SILVA RAMOS afirma que a origem do efeito vinculante trazido do Direito Alemão está na influência do judicial review norte-americano. Todavia, ressalta o autor, o "transplante institucional pretendido, portanto, afigura-se extremamente problemático, tendo-se em conta que o controle de constitucionalidade brasileiro possui natureza eminentemente jurisdicional e, mais do que isso, ainda hoje é exercido, predominantemente, no âmbito da jurisdição ordinária, de acordo com princípios e regras processuais comuns" (Controle de constitucionalidade no Brasil:perspectivas de evolução, p. 293).
} 
eficácia significa dizer que seus efeitos aproveitam a todos, se fazem sentir em face de $\operatorname{todos}^{203}$.

Daí por que a "força vinculante assume uma relevância autônoma, merecedora de consideração específica, apenas quando imponível em face daqueles que são terceiros em relação ao processo", ou seja, àqueles que não tiveram oportunidade de exercer o contraditório $^{204}$.Em outros termos, como explica LUIZ GUILHERME MARINONI,

"a qualidade que reflete a imutabilidade da decisão judicial em relação às partes - denominada de coisa julgada - não se confunde com o stare decisis. A coisa julgada garante às partes a imutabilidade da decisão. $\mathrm{O}$ respeito aos precedentes confere aos jurisdicionados a estabilidade de dada interpretação jurídica"205.

Por sua vez, o efeito vinculante faz que não apenas os legitimados para o processo objetivo (por isso, não nos referirmos a partes) fiquem vinculados à decisão dele dotada. Mas, por outro lado, é necessário ponderar que a força vinculante não é simplesmente uma "coisa julgada erga omnes", pois existem decisões que são vinculantes tãologo proferidas, das quais são exemplo as liminares em ações diretas ${ }^{206}$.

A vinculação é intrínseca à eficácia normativa dos citados precedentes do STF e redunda, portanto, na obrigatoriedade de cumprimento e obediência por todos que se vincularem à norma contida na decisão, os quais passam a ter de cumpri-la e respeitá-la, sob pena de serem instados a fazê-lo pelo tribunal, entre outros modos, via reclamação ${ }^{207}$.

\footnotetext{
${ }^{203}$ FERRARI, Efeitos da declaração de inconstitucionalidade, p. 238. Esse conceito foi expresso pelo MIN. MOREIRA ALVES no julgamento da ADC 1/DF.

${ }^{204}$ TALAMINI, Objetivação do controle incidental de constitucionalidade e força vinculante (ou "devagar com o andor que o santo é de barro"), in: NERY JR.;WAMBIER (org.).Aspectos polêmicos e atuais dos recursos cíveis e assuntos afins, v. 12, p. 137. O autor vai além, para afirmar que toda sentença é apta a atingir terceiros independentemente da coisa julgada, pois, como ato estatal, já é dotada de imperatividade (ob. cit., p. 138).

${ }^{205}$ Precedentes obrigatórios, p. 111. Segundo o autor, o que caracteriza a eficácia absolutamente vinculante é "a circunstância de o juiz não poder revogar a decisão, ainda que tenha bons fundamentos para não respeitála". É claro, pondera, ainda, o autor, que essa condição não impede o juiz de "fazer o distinguished do caso que lhe é submetido, ou seja, de evidenciar que a questão posta para julgamento é diferente ou que os fatos da causa que está para ser julgada tornam a questão de direito distinta da já decidida" (p. 112).

${ }^{206}$ TALAMINI, Objetivação do controle incidental de constitucionalidade e força vinculante (ou "devagar com o andor que o santo é de barro", p. 139. Pela mesma razão, TEORI ZAVASCKI entende que o efeito vinculante é também ex tunc, mas seu termo inicial se desencadeia com a sentença que declarou a constitucionalidade ou a inconstitucionalidade, e não com o início de vigência da norma examinada, podendo-se situar, como termo inicial do efeito vinculante, nesses casos, a data da publicação do acórdão no Diário Oficial (art. 28 da Lei 9.868/1999) (Eficácia das sentenças na jurisdição constitucional, p. 64).

${ }^{207}$ FerRARI, Regina Maria Macedo Nery, ob. cit., p. 239. TEORI ZAVASCKI, mencionando voto do Min. Moreira Alves no julgamento da ADC 1, é expresso ao ligar a eficácia vinculante ao cabimento da reclamação: "o efeito vinculante confere ao julgado uma força obrigatória qualificada em relação a
} 
A par dessas ponderações é que acolhemos o conceito da doutrina segundo o qual efeito vinculante significa a força atribuída a uma decisão judicial capaz de torná-la obrigatória a todos, independentemente de sua efetiva participação no processo. Mas, como essa força, assim desenhada, confundir-se-ia com a eficácia natural da coisa julgada erga omnes e como o Código de Processo Civil limita essa eficácia ao dispositivo, é necessário reconhecer um traço que as distinga. E esse distintivo está no fato de que o efeito vinculante abarca, também, as razões de decidir ${ }^{208}$.

Assim, muito embora se trate de conceito cuja definição fica a cargo do legislador, sem nos distanciarmos da lei e da Constituição, entendemos que a eficácia vinculante deva, sim, abarcar os fundamentos determinantes da decisão, os quais, a propósito, compõem necessariamente a tese colmatada. Resta, afinal, verificarmos quais decisões do STF e do

supervenientes atos administrativos ou judiciais, com a consequência processual de assegurar, em caso de recalcitrância, a utilização de um mecanismo executivo próprio - a reclamação - para impor o seu cumprimento (Eficácia das sentenças na jurisdição constitucional, p. 63-64). Entretanto, não concordamos com a posição externada pelo autor ao afirmar que, também em sede de controle concreto exista a eficácia vinculante, desde que considerados os limites subjetivos próprios - isto é, inter partes -, já que tais sentenças, não sendo cumpridas, conferem ao interessado a faculdade de postular medidas processuais destinadas a obter a sua execução forçada (idem ibidem, nota de rodapé 32). Na verdade, o autor parece confundir a eficácia natural de toda tutela jurisdicional com a obrigatoriedade que distingue as decisões vinculantes.

${ }^{208}$ ROGER STIEFELMANN LEAL conclui que o efeito vinculante é voltado a "tornar obrigatória parte da decisão diversa da dispositiva aos órgãos e entidades relacionados no texto normativo. Assim, seu objeto transcende ao decisum em sentido estrito, alcançando os seus fundamentos determinantes, a ratio decidendi subjacente ao julgado". Afinal de contas, a incompatibilidade entre o ato apontado como desrespeitador e a decisão vinculante somente poderá ser aferida "a partir da ratio decidendi que fundamenta a decisão" ( $O$ efeito vinculante na jurisdição constitucional, p. 150-151). ELIVAL DA SILVA RAMOS adota entendimento contrário, segundo o qual somente se houvesse previsão constitucional expressa se poderia afirmar que o efeito vinculante abarca os fundamentos da decisão: "Destarte, propugnamos por outro entendimento, que, sem atribuir à expressão 'efeito vinculante' sentido meramente de reforço em relação à coisa julgada erga omnes, não a remete à motivação das decisões de controle, o que desnaturaria, com consequências imprevisíveis, o nosso sistema de fiscalização constitucional em via principal". Para o autor, o efeito vinculante deve ser entendido como capaz de tornar obrigatória a observância do quanto decidido pelo Supremo Tribunal Federal aos demais órgãos do Poder Judiciário e da Administração Pública, sob pena de responsabilização administrativa e civil, consequência que não poderia se verifica, segundo ele, caso se tratasse apenas de eficácia preclusiva da coisa julgada (Controle de constitucionalidade no Brasil-perspectivas de evolução, $\mathrm{p}$. 293-294). Cabe mencionar aqui que, embora seja corrente a ideia de que o efeito vinculante não obriga o Poder Legislativo, o Supremo Tribunal Federal já decidiu que essa regra deve ser vista com ressalva: "A JURISPRUDÊNCIA DO SUPREMO TRIBUNAL ADMITE A RECLAMAÇÃO PARA ASSEGURAR A AUTORIDADE DE SUAS DECISÕES POSITIVAS EM AÇÃO DIRETA DE INCONSTITUCIONALIDADE, QUANDO O MESMO ÓRGÃO DE QUE EMANARA A NORMA DECLARADA INCONSTITUCIONAL PERSISTE NA PRÁTICA DE ATOS CONCRETOS QUE LHE PRESSUPORIAM A VALIDADE (CF. RECLS. 389, 390 E 393). NO CASO, DADO QUE A MEDIDA CAUTELAR NA AÇÃO DIRETA TEM EFICÁCIA $E X N U N C$, O SEU DEFERIMENTO NÃO AFETOU A DO ATO CONCRETO ANTERIOR, EM RELAÇÃO AO QUAL NÃO SE CONHECEU DA AÇÃO DIRETA: DA DECISÃO LIMINAR PARA FRENTE, NO ENTANTO, O EFEITO ÚTIL DA SUSPENSÃO CAUTELAR DA RESOLUÇÃO IMPUGNADA FOI PRECISAMENTE O DE IMPEDIR QUE SE CONTINUASSEM A PRATICAR ATOS CONCRETOS DERIVADOS DO SEU CONTEÚDO NORMATIVO” (Rcl. 399/PE, Pleno, rel. MIN. SEPÚLVEDA PERTENCE, j. 07/10/1993, DJ 24/03/1995). 
STJ são dotadas de efeito vinculante capaz de obrigar à obediência à tese jurídica nelas definida e abrir caminho para o uso da reclamação quando essa tese não for observada. 


\section{CAPítUlo 3 - RECLAMAÇÃo NO CONTROLE DA APLICAÇÃo DE PRECEDENTES DO STF E DO STJ}

Muito embora seja inegável o movimento tendente a tornar os precedentes judiciais obrigatórios, a verdade é que poucos são, de fato, dotados de efeito vinculante, a ponto de ser permitido o uso da reclamação como meio de controle da tese jurídica.

No sistema processual em vigor hoje ${ }^{209}$, nem mesmo as decisões que fixam teses em julgamento de recursos extraordinários e especiais representativos da controvérsia sob o regime dos repetitivos (arts. 543-B e 543-C do CPC) são vinculantes a ponto de tornar possível o controle de sua observância pelo uso da reclamação ${ }^{210}$. Nem a exigência de

\footnotetext{
${ }^{209}$ O novo Código de Processo Civil, como será visto em item próprio, amplia o cabimento da reclamação e, a reboque, torna as decisões tomadas em julgamento de casos repetitivos vinculantes, permitindo que qualquer interessado possa bater às portas do STF e do STJ - e dos demais tribunais - em caso de não observância da tese jurídica fixada nos precedentes (este, é o termo usado pelo artigo 985, IV, do projeto).

${ }^{210}$ Não ignoramos os casos em que o STF admite a reclamação para garantir a eficácia da decisão tomada em sede de recurso extraordinário, mas estritamente com relação à determinação de suspensão dos processos que cuidem da mesma controvérsia (por exemplo: Rcl. 12.829, rel. MIN. CÁRMEN LÚCIA, DJe 07/06/2013; Rcl. 11.724, rel. MIN.DIAS TOFFOLI, DJe 04/06/2013; Rcl. 12.739, rel. MIN. TEORI ZAVASCKI, DJe 18/02/2013;Rcl. 11.995, rel. MIN. RICARDO LEWANDOWSKI, DJe 26/03/2013; Rcl. 13175/SP, decisão monocrática, rel. MIN. ROSA WEBER, Dje 20/08/2013; e Rcl.12.681, 1. ${ }^{a}$ T., rel. MIN. MARCO AURÉLIOMELLO, DJe 28/06/2013, a qual possui a seguinte ementa: "RECLAMAÇÃO - REPERCUSSÃO GERAL - PRONUNCIAMENTO DO SUPREMO - INOBSERVÂNCIA - ADEQUAÇÃO. A erronia na observância de pronunciamento do Supremo formalizado, sob o ângulo da repercussão geral, em recurso extraordinário gera o acesso ao Tribunal mediante a reclamação. REPERCUSSÃO GERAL - RECURSO EXTRAORDINÁRIO - LIMINAR - ALCANCE. No que ressalvada, na liminar implementando a suspensão do processo, a existência de título judicial transitado em julgado, tem-se alcançada situação jurídica reveladora da fase de execução, muito embora se mostre necessário que venha a ser apurado, em processo de liquidação, o valor devido.”). Todavia, também nessa espécie não se está a resguardar uma tese jurídica de observância obrigatória estabelecida pelo Tribunal. Aliás, a suspensão buscada é prova de que a tese ainda não se fixou. Trata-se, bem vista a questão, de utilização da reclamação como garantia da eficácia executiva natural da decisão do STF, da qual toda decisão é dotada. De resto, prevalece o seguinte entendimento: "[...] acerca da sistemática da repercussão geral, na sessão plenária de 19/11/09, o STF firmou o entendimento no sentido de que o agravo dirigido ao Supremo Tribunal Federal, bem como a reclamação constitucional ajuizada originariamente nesta Corte, não seriam o meio adequado para a parte questionar decisão de Tribunal a quo mediante a qual se julga prejudicado recurso aplicando súmula de repercussão geral(AI $\mathrm{n}$. 760.358/SE-QO, Relator o Ministro Gilmar Mendes e Reclamações n. 7.569/SP e 7.547/SP, de da Ministra Ellen Gracie). A questão voltou a ser debatida nas sessões plenárias de 29/6/11, 4/8/11 e 30/10/13, no julgamento das Reclamações n. 11.408/RS-AgR e 11.427/MG-AgR - no qual se ponderou no sentido de se admitir a reclamação quando verificada erronia na aplicação de súmula de repercussão geral pela Corte de origem -, o qual está suspenso por pedido de vista do Ministro Roberto Barroso"(Rcl. 16618 AgR/PB, rel. MIN. DIAS TOFFOLI, 1. ${ }^{\mathrm{a}}$ T., j. 04/11/2014, DJe 21/11/2014).
} 
repercussão geral como condição de procedibilidade do recurso extraordinário foi capaz de tornar as soluções do STF vinculantes, embora, como se verá, seja uma tendência ${ }^{211}$.

Importa é consignar que o controle da aplicação das teses, em todos esses casos, é feito pelas vias ordinárias (recursos e sucedâneos recursais) e, vale destaque, de acordo com as regras ordinárias de competência, não sendo possível atalhar o caminho até os tribunais superiores. Portanto, em que pese a ideia do legislador reformista tenha sido a de coletivizar demandas em fase de recurso excepcional (especial e extraordinário), sem a atribuição de eficácia vinculante ao produto final do procedimento, a técnica só serve para reduzir o trabalho forense, deixando de lado seu objetivo mais nobre, que é a harmonização dos entendimentos e a justiça e a segurança que dela advêm ${ }^{212}$.

${ }^{211}$ A necessidade de um filtro de causas para as Cortes Superiores é defendida por quase toda a doutrina. Afirma, Rodolfo DE CAMARGo MANCuSO, que "parece indisputável que algum tipo de controle, filtro ou triagem há de existir para o acesso às Cortes Superiores, quanto mais não seja ante a evidente desproporção entre o número de ministros e o volume exacerbado de processos que, de outro modo, ali aportariam, sem um critério distintivo ou regulador; outrossim, a singela alternativa do aumento do número de julgadores, sobre não resolver o problema, acarretaria a indesejável macrocefalia da estrutura do Poder Judiciário, de per si já bastante avantajada" (Recurso extraordinário e recurso especial, p. 77).Também se costuma rememorar o instituto da arguição de relevância para o recurso extraordinário, que vigorou entre 1975 e 1988, para afirmar que se trata de uma arguição com sinal trocado, pois, no sistema atual, a relevância é presumida até que o Supremo, por oito de seus onze membros, decida por sua inexistência no caso. E o STF já decidiu ser de sua exclusiva competência a análise da existência ou não da repercussão geral (AI-QO 664.567, rel. MIN. SEPÚlVEDA PERTENCE, DJU 06/09/2007). A propósito da arguição, DinAMARCO anota que tal requisito era exigido pelo art. 308 do Regimento Interno do Supremo Tribunal Federal, o qual por sua vez estava autorizado pela Constituição vigente a complementar a disciplina constitucional da admissibilidade do

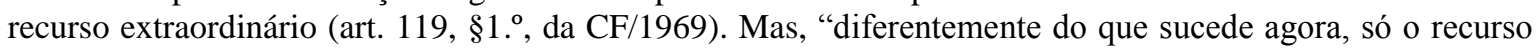
extraordinário fundado em matéria infraconstitucional estava condicionado a tal pressuposto, e não o que fosse interposto com fundamento em infração à Constituição Federal”. Hoje se dá exatamente o contrário: “o recurso em matéria infraconstitucional não depende da repercussão geral (o recurso especial) e o recurso em matéria constitucional, sim" (A reforma constitucional do Poder Judiciário, in Fundamentos do processo civil moderno, tomo I, p. 208).

212 Segundo CÂNDIDO DINAMARCO, o procedimento dos recursos repetitivos é mais uma técnica coletivizadora, a qual "é comandada pelo mesmo ideário que conduziu à instituição das súmulas vinculantes, na medida em que tanto lá como cá se tem em vista o duplo objetivo de agilizar os trabalhos da Justiça e harmonizar julgamentos mediante a propagação dos efeitos dos julgados do Superior Tribunal de Justiça" (Súmulas vinculantes, p. 244). Como ensina TIAGO ASFOR RoCHA LIMA, "trata-se, claramente, de medida de economia processual, com repercussão direta e imediata na celeridade do processo e no desafogamento do Supremo Tribunal, fortalecendo ainda as decisões da Corte". A emenda constitucional veio trazer, portanto, não apenas um filtro dos recursos extraordinários julgados pela Suprema Corte, mas também um "elemento de fortalecimento da objetivação desses recursos" (Precedentes judiciais civis no Brasil, p. 47-48). Para GILMAR MENDES, a adoção do novo instituto deverá "maximizar a feição objetiva do recurso extraordinário". Segundo o autor e Ministro do STF, importante ressaltar a expressiva redução no número de processos distribuídos no STF no ano de 2008, "como resultado da adoção de medidas de racionalização processual e de filtros recursais voltados a solucionar o antigo desafio dos recursos idênticos e mecanicamente protocolados". Segundo ele, "pela primeira vez o Tribunal experimentou significativa diminuição no total de processos distribuídos - cerca de $41 \%$-, obtida principalmente com a aplicação do instituto da Repercussão Geral, abrindo espaço para que o Tribunal possa se concentrar no debate de assuntos de maior impacto social" (Controle abstrato de constitucionalidade: ADI, ADC e ADO, p. 54-55). Comparando a evolução do número de processos protocolizados no STF e no STJ e concluindo que este último não sentiu tanto os efeitos 
Mas a realidade tem mostrado que nem mesmo o efeito vinculante foi capaz de potencializar o respeito à sua autoridade. Ao contrário, nos deparamos com um número cada vez maior de reclamações justamente no intuito de ver garantida a "autoridade" de suas decisões (sem contar os recursos e as ações que tramitam pelas instâncias ordinárias). À medida que se ampliam as hipóteses de cabimento, amplia-se a sua utilização.

Assim, o receio de que os recursos venham a ser substituídos pelas reclamações deriva da constatação de que, quando o rol de legitimados para a reclamação corresponde ao universo de atingidos pelos efeitos das decisões cuja autoridade se visa a garantir, se o efeito for erga omnes ou vinculante, todos poderão bater às portas do STF e do STJ; e sem que, para isso, tenham de passar por metade dos obstáculos que seriam obrigados a superar caso apenas lhes restassem o recurso extraordinário e o especial.

\subsection{Reclamação no controle de constitucionalidade}

Ao cuidarmos da reclamação voltada a controlar a observância de precedente obrigatório do Supremo Tribunal Federal, importa pontuar que estamos falando de decisões tomadas em sede de controle de constitucionalidade ${ }^{213}$, ou seja, tomadas no desempenho de sua função de Corte Suprema ${ }^{214}$. Assim também, vale lembrar que a

das últimas reformas que afetaram os recursos especial e extraordinário, ALUISIO GONÇALVES DE CASTRO MENDES afirma que "a grande diferença foi o não estabelecimento de filtro da repercussão geral, como requisito para a admissibilidade do recurso especial no STJ". Daí porque, segundo o autor, a comparação mostra que não foi principalmente o incidente de recursos repetitivos, "mas, sim, a exigência de repercussão geral que teria propiciado a queda constante e gradativa no STF" (Resolução coletiva de conflitos, in: $O$ processo em perspectiva:Jornadas Brasileiras de Direito Processual, p. 63).

${ }^{213}$ Com relação ao Supremo, em primeiro lugar, importa lembrar que a ideia que se tinha durante os debates em Assembleia Constituinte, de se criar um tribunal constitucional, não se confirmou na prática, de modo que sua competência ficou sobremodo elastecida, e a doutrina costuma subdividir as competências do STF com relação ao conteúdo da prestação jurisdicional em três grupos: (1) quando há controle de constitucionalidade, (2) se não há controle de constitucionalidade e (3) as hipóteses em que se tutelam as liberdades (garantia dos direitos) (OSCAR VILHENA VIEIRA, Supremo Tribunal Federal: jurisprudência política, p. 83-85). Muito embora possa não haver previsão constitucional nem legal da eficácia expansiva de determinadas decisões exaradas pelo Supremo, o simples fato de se postar no cume do Poder Judiciário é suficiente para que seus julgados sejam dotados de eficácia persuasiva incontestável perante os demais tribunais e juízos do país. Mas, para o fim de se saber cabível o controle da aplicação de seus julgados por meio da reclamação constitucional, esse efeito persuasivo não basta, de modo que deveremos nos ater àquelas decisões que sejam dotadas de efeitos vinculantes.

${ }^{214}$ Embora possamos estar caminhando para o engrandecimento da função de corte suprema do STF, a verdade é que a Constituição Federal desenhou-o com dupla função: guardião da constituição quando exerce o controle difuso ou concentrado, e corte superior nas demais hipóteses de competência originária (remédios constitucionais), de recurso ordinário e de foro privilegiado por prerrogativa de função. Sobre a distinção entre cortes supremas e cortes superiores, v. MitIDIERO, Cortes Superiores e Cortes Supremas: do controle à interpretação, da jurisprudência ao precedente. Diz o autor, com o intuito de conclamar a uma nova forma de 
hipótese aqui tratada busca fundamento no artigo 102, I, $l$, da Constituição Federal, que cuida da garantia da autoridade das decisões do Supremo Tribunal Federal ${ }^{215}$.

Não há dúvida, portanto, que há várias decisões do Supremo Tribunal Federal que mantêm sua eficácia confinada ao caso concreto. Assim, por exemplo, é o que ocorre nos processos criminais de sua competência originária (foro privilegiado), nos recursos ordinários (salvo se houver decisão incidental a respeito da constitucionalidade de lei ou ato normativo), muito embora possa haver, nesses processos, controle concreto e incidental de constitucionalidade. Isso é prova de que, também em sede de controle de constitucionalidade, há decisões que não são dotadas de eficácia erga omnes e efeitos vinculantes.

Ao analisarmos o sistema brasileiro de controle de constitucionalidade, em primeiro lugar, não podemos perder de vista seu caráter híbrido consistente na coexistência de duas técnicas que atuam paralelamente: o controle concentrado, de origem austríaca, no qual a resolução da questão constitucional consiste no próprio objeto do processo, e o controle difuso, de origem estadunidense, no qual a questão consubstancia uma prejudicial ao exame do mérito, sendo decidida incidenter tantum $^{216}$.

\footnotetext{
ver o STF e o STJ, a qual deve nortear até o modo de interpretar dispositivos constitucionais e legais relativos a esses dois tribunais, verbis: "Se quisermos ter cortes judiciárias de vértice compatíveis com a maneira como o Direito é entendido hoje e que tenham condições de desempenhar suas altas funções de modo racional, é fundamental compreendê-las como um todo orgânico - isto é, desde uma perspectiva pensada a partir de modelos coerentes [...] O Supremo Tribunal Federal e o Superior Tribunal de Justiça, como cortes responsáveis por dar a última palavra a respeito da interpretação da Constituição e da legislação infraconstitucional federal na ordem jurídica brasileira, devem ser pensados como Cortes Supremas, a fim de que se possa reconstruí-los em termos conceituais, estruturais, funcionais e eficaciais a partir de um quadro teórico capaz de fornecer soluções coerentes aos problemas ligados à interpretação judicial no Estado Constitucional" (ob. cit., p. 32 e 79).

${ }^{215}$ Tratando-se de hipótese em que o reclamado é órgão do próprio Poder Judiciário, não se pode confundir o descumprimento que originou a reclamação com um futuro descumprimento da decisão que nela tomar o STJ ou o STF. Naquele, o juiz não é parte sujeita às penalidades decorrentes da litigância de má-fé (art. 14 do CPC). Basta verificar que o próprio dispositivo do Código de Processo Civil é endereçado ao magistrado, a quem compete zelar pela efetividade da tutela jurisdicional, aplicando a pena ao faltoso. Entretanto, se descumprir a decisão tomada na reclamação, parece razoável a ponderação de LUANA PEDROSA DE FIGUEIREDO CRUZ a respeito do STJ, mas também aplicável às decisões do STF, segundo a qual o magistrado que não cumprir o quanto determinado pelo STJ poderá "estar sujeito à apenação pela conduta de violação aos deveres das partes, pois partes são, como outra qualquer, na ação de reclamação" (Reclamação constitucional para garantia de autoridade de decisão do STJ e a violação dos deveres das partes, p. 1172). Parece mesmo coerente e razoável que, dada a sua natureza de remédio constitucional (ação), o juiz que descumprir a decisão da reclamação, como autoridade reclamada que é, ficará sujeito às penas do artigo 14 . Assim, parece viável requerer já na petição inicial da reclamatória, como decorrência da procedência da reclamação e para o caso de não cumprimento imediato do comando emergente do acórdão que a julgar, a apenação do magistrado recalcitrante.

${ }^{216}$ Há um duplo objetivo nessa associação de métodos, sempre visando a uma maior eficiência do sistema de controle: a uniformização (eficiência qualitativa) das decisões, o que é propiciado pela solução da questão
} 
Esse aspecto, que é relevantíssimo, é responsável por um sem-número de confusões, geradas pela tentativa de aplicar regras de um regime a outro, sem que haja a análise de sua compatibilidade e das consequências geradas por essa incompatibilidade. Entre essas tentativas, sem dúvida, está a equiparação da eficácia das decisões tomadas sob ambos os regimes. A respeito dessa coexistência de técnicas, tornou-se clássica a advertência de MAURo CAPPELletti ${ }^{217}$, lembrada, com proficiência pelo Ministro SEPÚlvedA PERTENCE no voto que proferiu no RE $191.896^{218}$ :

A adoção no Brasil, com a Federação e a República, do sistema americano de controle difuso e incidente da constitucionalidade das leis sofreu profundamente - como em outros ordenamentos de matriz romanista - carência do dogma do stare decisis, que, nos Estados Unidos, superou de fato os inconvenientes e riscos da eficácia teoricamente restrita ao caso concreto e às partes do litígio da declaração incidenter de inconstitucionalidade ${ }^{219}$.

Com efeito, a transposição do sistema difuso não poderia mesmo trazer consigo a necessária cultura de respeito a precedentes, sem a qual nos deparamos com decisões da

com efeitos erga omnes, e a abrangência maior (eficiência quantitativa) da fiscalização (RAMOs, Controle de constitucionalidade no Brasil: perspectivas de evolução, p. 250-251).

${ }^{217} \mathrm{O}$ controle judicial das leis no direito comparado, p. 76-80. MARINONI afirma que a constatação de CAPPELLETTI Foi por muito tempo ignorada no Brasil, "certamente por alguma razão inconfessável que prefere apostar na irracionalidade do sistema jurídico" (A ética dos precedentes, p. 56).

218 1. a T., rel. Min. SEPÚlVEdA PERTENCE, j. 27/05/1997. No caso, a 1. ${ }^{a}$ Turma, na linha de precedentes nele citados, aceitou emprestar, às declarações de inconstitucionalidade incidentais, a eficácia de quebrar a presunção de constitucionalidade das normas e, com isso, afastar a incidência da reserva de plenário estabelecida no artigo 97, da CF/1988. Vale lembrar que a Lei Federal 9.756/1998, ao acrescentar o parágrafo único ao artigo 481 do CPC, incorporou a ele esse entendimento do Supremo, ou seja, passou a dispensar a reserva de plenário nos casos em que este ou o Supremo já tenham decidido a questão.

${ }^{219}$ Depois de lembrar que os inconvenientes decorrentes da transplantação a regimes da civil lawdo método americano de controle incidente foram contornados pela possibilidade de o próprio Tribunal de cúpula conferir eficácia erga omnes às declarações de inconstitucionalidade feitas no controle concreto, o Ministro ressalvou que, no Brasil, não se chegou a tanto. De fato, desde a Constituição Federal de 1934, o mecanismo criado para dar eficácia universal às declarações de inconstitucionalidade foi a outorga de competência ao Senado Federal para "suspender a execução (...) de qualquer lei ou ato, deliberação ou regulamento, quando hajam sido declarados inconstitucionais pelo Poder Judiciário"(CF/1934, art. 91, IV), prestando homenagem "à ortodoxia da separação dos poderes". Consta, ainda, do voto do relator: "O instituto - desaparecido na Carta do Estado Novo - reaparece na Constituição de 1946, que, entretanto, tornou explícita a limitação de seu alcance, como se impunha, às decisões definitivas do Supremo Tribunal Federal (art. 64), mantendo, de resto, a exigência originária do texto de 1937 (art. 96), do voto da maioria absoluta dos membros do tribunal para a declaração de inconstitucionalidade de lei ou ato do Poder Público (art. 200). As duas regras permanecem nas constituições brasileiras subsequentes inclusive a atual (Const. 1988, art. 52, X), convivendo com a adoção plena, mas paralela, desde a EC 16/65, do sistema de controle direto e concentrado, no âmbito do qual a eficácia erga omnes é efeito direto e imediato da própria decisão declaratória de inconstitucionalidade, prescindindo, por isso, da deliberação ulterior do Senado. Certo, assim, que, quando exarada incidentemente, para resolver questão prejudicial do caso concreto, a declaração de inconstitucionalidade - malgrado emanada do próprio Supremo Tribunal que, mediante ação direta, poderia proferi-la com eficácia erga omnes-, é de eficácia relativa. A essa eficácia relativa da decisão - restrita ao âmbito objetivo e subjetivo do processo em que tomada -, soma-se, no entanto, como visto, a de constituir o pressuposto necessário e suficiente a que o Senado Federal lhe empreste alcance erga omnes." 
mais alta Corte do País sendo descumpridas diariamente. Por isso, tem razão quem afirma ser inadmissível, em um sistema de controle difuso de constitucionalidade, permitir que juízes e tribunais ordinários desrespeitem os precedentes constitucionais da Corte Suprema. A introdução do sistema estadunidense no Brasil, para ser eficaz, dependia de se dar cabo à prática de desrespeito pelos órgãos inferiores das decisões tomadas pelo órgão máximo da hierarquia, responsável por dar a última e definitiva interpretação ao texto constitucional $^{220}$.

Exercendo, portanto, o controle difuso de constitucionalidade, no Brasil, todo juiz pode declarar, de forma incidental, ou seja, nos fundamentos da sua decisão, a validade de determinada norma em relação à Constituição Federal, incluindo, evidentemente, o próprio Supremo Tribunal Federal, que o faz tanto em causas de sua competência originária como nas demais, quando lá aportarem via recurso extraordinário. Todavia, segundo entendimento majoritário, as decisões tomadas nesses casos concretos pelo Supremo valem apenas para o caso em que foram proferidas, não sendo dotadas de eficácia erga omnes e vinculante $^{221}$.

Estamos tratando aqui da chamada teoria da objetivação do controle difuso ${ }^{222}$, segundo a qual, partindo da premissa de que todas as decisões do Supremo Tribunal Federal em sede de controle de constitucionalidade devem ter a mesma eficácia, defende que também as decisões tomadas incidentalmente devem ser vinculantes. Em verdade, na linha do exposto no tocante ao hibridismo de nosso sistema, tratar-se-ia de uma decorrência natural da importação da técnica difusa norte-americana, pois naquele país vigora o stare decisis, ou seja, os precedentes são obrigatórios.

\footnotetext{
${ }^{220}$ MARINONI, A ética dos precedentes, p. 55-56.

${ }^{221}$ Vale mencionar a advertência de ARAKEN DE AsSIS, quando analisa os efeitos das decisões tomadas em sede de recurso extraordinário: "é uma ilusão grosseira supor que a decisão do STF, proclamando a inconstitucionalidade de normas no controle difuso, produza unicamente eficácia inter partes". Em seguida, elenca vários outros efeitos que seriam extra partes, na linha do que expusemos ao tratar da eficácia das decisões do Supremo (Manual dos recursos, p. 811-812). O fato é que nenhum deles chega a configurar a eficácia vinculante de que são dotadas as decisões do controle concentrado.

${ }^{222}$ Assim: DANTAS, Marcelo Navarro, Novidades em reclamação constitucional: seu uso para impor o cumprimento de súmula vinculante, in: MEDINA et al. (org.). Os poderes do juiz e o controle das decisões judiciais: estudos em homenagem à professora Teresa Arruda Alvim Wambier;MINGATI, in:Reclamação (neo)constitucional: precedentes, segurança jurídica e os Juizados Especiais, p. 71; TALAMINI, Objetivação do controle incidental de constitucionalidade e força vinculante (ou "devagar com o andor que o santo é de barro"), in:NERY JUNIOREWAMBIER. Aspectos polêmicos e atuais dos recursos cíveis e assuntos afins, $\mathrm{n}$. 12 , p. 135-166.
} 
Mas aqui temos de concordar com TALAMINI quando afirma que a atribuição de efeitos vinculantes ao controle concreto de constitucionalidade exercido pelo Supremo Tribunal Federal, além de não vir expressa na Constituição Federal, esbarra tanto na necessidade de atuação do Senado Federal, para a suspensão de eficácia da norma declarada inconstitucional, quanto, sobretudo, nas limitações impostas pela própria Constituição à edição de verbetes vinculantes ${ }^{223}$.

Em outras palavras, além de não ser prevista na Carta, a chamada objetivação do controle difuso de constitucionalidade contraria frontalmente a regulação feita pelo constituinte reformador da edição das "súmulas vinculantes". Assim, atribuir eficácia vinculante automática a toda e qualquer decisão do Supremo Tribunal Federal em sede de controle concreto, ainda que se trate de recurso extraordinário, necessariamente filtrado pela repercussão geral, é tornar inócua a reforma constitucional que, ao permitir a edição de verbetes com força vinculante, estabeleceu um procedimento limitado, razoável e condizente com o objetivo fixação de tese abstrata a partir de decisões de caso concreto, para o que, por exemplo, exige quórum qualificado, atualidade da controvérsia com risco de grave insegurança jurídica e relevante multiplicação de processos.

É dizer, se é tão natural o efeito vinculante das decisões do Supremo em sede de controle difuso, o que justifica as limitações impostas à edição de verbetes vinculantes? $\mathrm{O}$ contrassenso demonstra, a nosso ver, o acerto dos que entendem que a objetivação do controle difuso de constitucionalidade, embora possa fazer algum sentido do ponto de vista teórico e até pragmático, não é consentânea com o atual sistema constitucional brasileiro.

$\mathrm{Na}$ prática, portanto, a única expressão viável dessa objetivação encontra-se na possibilidade de, a partir de casos julgados em sede de controle concreto, editarem-se

\footnotetext{
${ }^{223}$ Objetivação do controle incidental de constitucionalidade e força vinculante (ou 'devagar com o andor que o santo é de barro'), p. 159-166. No mesmo sentido:Ramos, Controle de constitucionalidade no Brasil perspectivas de evolução, p. 253. Defendendo o anacronismo da competência atribuída ao Senado, LuIS ROBERTO BARROSO se mostra favorável à tese de que não faz sentido uma decisão do Plenário do Supremo Tribunal Federal sobre a constitucionalidade de uma lei ou ato normativo não possuir o mesmo efeito que outra só por ter sido tomada em sede recursal (O controle de constitucionalidade no Direito Brasileiro, $\mathrm{p}$. 110-111). A propósito da necessária atuação do Senado, nos termos do artigo 52, X, da CF/1988, o Supremo Tribunal Federal, ao julgar a Rcl. 4335/AC, rel. MiN. GILMAR MENDES, j. 20/03/2014, DJe 21/10/2014, reafirmou o entendimento de que é necessária a manifestação desse órgão para que as decisões tomadas em sede de controle difuso passem a valer contra todos de modo vinculante. Curioso que, nesse julgamento, o MiN. LuIS RoBERTO BARROSO não chegou a ponto de acompanhar a posição do relator, que defendia a desnecessidade da manifestação do Senado para que se reconheça eficácia erga omnes e vinculante às decisões tomadas em sede de controle concreto.
} 
verbetes sumulares vinculantes. Trata-se de posição sedimentada no STF, cuja maioria dos Ministros ainda não consegue driblar o texto expresso do artigo 52, X, da Carta da República, que atribui ao Senado a competência para suspender, no todo ou em parte, a execução de lei declarada inconstitucional pelo Supremo $^{224}$. Além de ser a posição predominante no Supremo, parece-nos ser a corrente doutrinária mais bem fundamentada $^{225}$.

Por sua vez, como já se teve oportunidade de citar, as decisões tomadas em sede de controle concentrado de constitucionalidade possuem eficácia erga omnes e veiculam tese de observância obrigatória. Tal ocorre, portanto, na ação direta de inconstitucionalidade, na ação declaratória de constitucionalidade e na arguição de descumprimento de preceito fundamental.

Com efeito, a Emenda Constitucional 45/2004, consagradora da chamada Reforma do Poder Judiciário, além de abrir a possibilidade de o Supremo Tribunal Federal editar súmulas de eficácia vinculante, alterou a redação do $§ 2 .^{\circ}$ do artigo 102 , para estabelecer que

"as decisões definitivas de mérito, proferidas pelo Supremo Tribunal Federal, nas ações diretas de inconstitucionalidade e nas declaratórias de constitucionalidade produzirão eficácia contra todos e efeito vinculante, relativamente aos demais órgãos do Poder Judiciário e à administração pública direta e indireta, nas esferas federal, estadual e municipal".

Todavia, quanto à extensão desse efeito vinculante e ao contrário do quanto defendemos, prevalece no STF o entendimento segundo o qual os chamados motivos determinantes da decisão não são acobertados pela obrigatoriedade, de modo que não se

\footnotetext{
${ }^{224}$ Vale, aqui, a leitura do acórdão publicado em 21/10/2014, do julgamento da Rcl. 4335/AC, rel. MIN. GILMAR MENDES.

${ }^{225}$ A propósito, concordamos com EdUARDo TALAMINI, para quem, "sob o aspecto da jurisdição constitucional, a súmula vinculante funciona precisamente como o mecanismo que faltava para dar coordenação ao modelo de controle de constitucionalidade adotado no Brasil", ou seja, "com a súmula vinculante, tal como instituída, foi-se, no contexto jurídico social e político atual, até o ponto a que se poderia e deveria razoavelmente ir nesse momento" (ob. cit., p. 166). Para os que defendem a desnecessidade de atuação do Senado, teria havido verdadeira "mutação constitucional" capaz de tornar a função daquele órgão meramente formalizante, a de fazer publicar a decisão do Supremo. A respeito, bem ponderou o MiN. SEPÚlVEDA PERTENCE, no voto que proferiu na Rcl. 4335/AC, antes mencionada, in verbis: "[...] não me animo à mutação constitucional proposta. E mutação constitucional por decreto do poder que com ela se ampliaria; o que, a visões mais radicais, poderia ter o cheiro de golpe de Estado. Às tentações do golpe de Estado não está imune o Poder Judiciário; é essencial que a elas resista".
} 
tem admitido reclamação visando a garantir a eficácia normativa completa da tese jurídica formatada pelo tribunal ${ }^{226}$.

Ainda com relação à eficácia vinculante, é imprescindível ao cabimento de toda e qualquer reclamação que haja a identidade material entre o paradigma invocado como violado e o ato impugnado. Isso quer dizer, contudo, que a ratio decidendi do precedente é que deve ter sido violada, pois esta deveria necessariamente compreender os motivos determinantes $^{227}$. Mesmo assim, vale consignar que, ao forçar a comparação entre

${ }^{226}$ Rcl. 5.703-AgR/SP, rel. MIN. CÁRMEN LÚCIA, DJe 16/09/2009; Rcl. 5.389-AgR/PA, rel. MIN.CÁRMEN LÚCIA, DJe 19/12/2007; Rcl. 9.778-AgR/RJ, rel. MIN. RICARDOLEWANDOWSKI, DJe 10/11/2011; Rcl. 9.294-AgR/RN, rel. MIN. DIAS TOFFOLI, Plenário, DJe 03/11/2011; Rcl. 6.319-AgR/SC, rel. MIN. EROS GRAU, DJe 06/08/2010; Rcl. 3.014/SP, rel.MIN. AYRES BRITTO, DJe 21/05/2010; Rcl. 2.475-AgR/MG, Redator para o acórdão o MIN. MARCO AURÉLIO, DJe 31.1.2008; Rcl. 4.448-AgR, Relator MIN. RICARDOLEWANDOWSKI, DJe 08/08/2008; Rcl. 2.990-AgR/RN, rel.MIN. SEPÚLVEDA PERTENCE, DJ 14.9.2007; Rcl. 5.365-MC/SC, Relator o Ministro Ayres Britto, decisão monocrática, DJ 15.8.2007; Rcl. 5.087-MC/SE, rel. MIN. AYRES BRITTO,decisão monocrática, DJ 18/05/2007;Rcl. 18634 AgR/SC, 1. ${ }^{a}$ T., rel. MIN. CÁRMEN LÚCIA, j. 11/11/2014, DJe 19/11/2014). Permanecem registrando entendimento diverso, pelo reconhecimento da chamada transcendência dos motivos determinantes, embora sem apresentar votos nesse sentido, os Ministros Gilmar Mendes e Celso de Mello. A posição favorável, por eles adotada, já foi expressa nos seguintes julgados: Rcl. 2.363, rel. MIN. GILMAR MENDES, Plenário, DJ 1.\%04/2005; Rcl. 4.692-MC, rel. MIN. CEZAR PELUSO, decisão monocrática, DJ 14/11/2006; Rcl. 4.387-MC, rel. MIN. CELSODE MELLO, decisão monocrática, DJ 02/10/2006; e Rcl. 1.987, rel. MIN. MAURÍCIOCORRÊA, DJ 21/05/2004. Em acórdão recente, entretanto, o Supremo parece ter reconhecido, ainda que expressamente o tivesse negado, a possibilidade de aplicação da ratio decidendi extraída de acórdão de ADI para fins de aplicação do parágrafo único do artigo 481 do CPC. Veja-se: "A reclamante sustenta que a autoridade judiciária, valendo-se de fundamento constitucional, afastou a incidência do Decreto n. 2.736/96 sem a necessária submissão da matéria à cláusula de reserva de plenário. Defende a procedência da presente reclamação a fim de que o STF anule a decisão impugnada, determinando ao e. TJSP que submeta o julgamento ao Órgão Especial, em respeito à SV n. 10. [...] A autoridade reclamada manifestou-se nos autos, oportunidade em que noticiou a existência de pronunciamento do Plenário desta Suprema Corte acerca do Decreto n. 2.736/96 do Estado do Paraná, decisão proferida no julgamento do pedido de liminar na ADI no 2.155/PR. [...] Nessa perspectiva, não há dúvida de que há inúmeros precedentes decididos pelo Plenário do STF acerca da matéria (necessidade de deliberação dos Estados e do Distrito Federal para a concessão e revogação de benefícios fiscais concernentes ao ICMS), bem como julgado específico sobre a inconstitucionalidade do Decreto n. 2.736/96 do Estado do Paraná, apto a afastar a necessidade de respeito à cláusula de reserva de Plenário, conforme disciplinado no parágrafo único do art. 481 do CPC, in verbis: [...]. Destaco que não se trata, no caso dos autos, de aplicação da teoria da transcendência dos motivos determinantes em sede reclamatória (que poderia levar a julgamento originário de constitucionalidade de normas pelo STF em sede de ação de rito abreviado, com reduzida fase instrutória), mas no reconhecimento de existência de precedente específico sobre a matéria julgado pelo Plenário do STF - ainda que destituído de efeito vinculante e eficácia erga omnes, uma vez que julgada prejudicada a ADI n. 2.155/PR por perda superveniente de objeto -, a fim e autorizar à autoridade judiciária competente para julgar a demanda decidir o caso concreto por deliberação de órgão fracionário. Acerca da ausência de violação ao princípio constitucional da reserva de Plenário em casos em que órgão judicial fracionário aplica entendimento sedimentado em jurisprudência pacífica do STF, destaco trecho do voto proferido pelo Ministro Ricardo Lewandowski no julgamento do RE n. 617.389/SP-AgR: (...).” (Rcl. 9.299, rel.MIN. DiAS TOFFoLI, Decisão Monocrática, j. 03/10/2012, DJe de 09/10/2012).

${ }^{227}$ Essa identificação, contudo, não é fácil e incorre, quase sempre, em subjetivismos interpretativos, nos moldes dos ocorrentes na confrontação de casos nos recursos especiais fundados em divergência jurisprudencial (art. 105, III, $c$, da CF/1988). RODOLFO DE CAMARGO MANCUSO ensina que, nessas hipóteses, "não basta o singelo confronto entre os arestos trazidos à colação, mas (i) é preciso demonstrar, analiticamente, os pontos em que a divergência se manifesta, e, (ii) impende sustentar, convincentemente, 
julgados, a reclamação acaba cumprindo o papel pedagógico de ensinar o tribunal a encontrar a norma extraível de suas decisões e, assim, ser um instrumento de reforço rumo a um verdadeiro e incorporado sistema de respeito aos precedentes.

Por fim, é necessário realçar que, embora as decisões de controle de constitucionalidade surtam efeitos retroativos no tempo (ex tunc $)^{228}$, o Supremo não reconhece viável a utilização da reclamação como meio de controlar essa eficácia, ou seja, não admite o cabimento da medida quando o ato reclamado for anterior à decisão paradigma $^{229}$.

Nada obstante a regra, em caso de reconhecimento da inconstitucionalidade, há permissão para a chamada "modulação de efeitos", que autoriza o Supremo Tribunal Federal, por maioria de dois terços de seus membros e em nome da segurança jurídica ou por razão de excepcional interesse social, a restringir os efeitos daquela declaração ou decidir que ela só tenha eficácia a partir de seu trânsito em julgado ou de outro momento que venha a ser fixado (art. 27 da Lei Federal 9.868/1999) ${ }^{230}$.

O artigo 27 da Lei 9.868/1999 é expresso e, em idêntico sentido, é o artigo 11 da Lei 9.882/1999, que regula a ADPF:

que a interpretação melhor para a questão federal em causa é aquela alcança no(s) acórdão(s) apontados como paradigma, porque é essa superioridade exegética que levará à reforma do acórdão recorrido" (Recurso extraordinário e recurso especial, p. 296). A única diferença é que, no caso da reclamação, o paradigma é infenso a análises, ao passo que, no recurso especial por divergência, a decisão paradigma pode estar correta (cf. bem apontou Barbosa MoreIRA, Comentários ao Código de Processo Civil, p. 585).

${ }^{228}$ No voto proferido no Recurso Extraordinário 395.902/RJ, o MIN. CELSO DE MELLO reconhece que, embora haja divergência doutrinária quanto à natureza jurídica da inconstitucionalidade - se inexistência, nulidade ou anulabilidade -, a jurisprudência do STF entende se tratar de nulidade, o que implica a regra da eficácia $e x$ tunc de seu reconhecimento. Regra esta cuja temperança já vinha sendo aceita pelo Supremo em sede de controle concentrado antes mesmo da previsão expressa em lei, fundada na autoridade da coisa julgada material bem como em razões de segurança jurídica e boa-fé: RE 78.594, rel. MIN. BILAC PINTO, 2. ${ }^{a}$ T., j. 07/06/1974, DJ 04/11/1974; RE 122.202/MG, rel. MIN. FRANCISCO REZEK, DJU 08/04/1994; HC 70.514, rel. MIN. SYDNEY SANCHES, Pleno, j. 23/03/1994, DJ 27/06/1997; RE 147.776, rel. MIN.SEPÚLVEDA PERTENCE, 1. a T., j. 19/05/1998, DJ 19/06/1998 (citados por ATAÍDE JÚNIOR, Precedentes vinculantes $e$ irretroatividade do direito no sistema processual brasileiro, p. 199-201).

${ }^{229}$ Destarte, "inexiste ofensa à autoridade de pronunciamento da Corte se o ato reclamado é anterior à decisão dela emanada" (Rcl. 12.741-AgR, rel. MIN.RICARDO LEWANDOWSKI). No mesmo sentido: Rcl. 4.962, Rel. MiN.CÁRMEN LÚCIA; Rcl. 10.590 ED, rel. MIN.RICARDO LEWANDOWSKI; Rcl. 7082 AgR/RJ, $1^{\text {a }}$ T., rel. MiN.ROBERTO BARROSO, j. 25/11/2014, DJe 10/12/2014).

${ }^{230}$ Como bem já ponderou o MIN. SEPÚlVEDA PERTENCE, em citação feita por MENDES (Controle abstrato de constitucionalidade, p. 570)“a alternativa radical da jurisdição constitucional ortodoxa entre constitucionalidade plena e a declaração de inconstitucionalidade ou revogação por inconstitucionalidade da lei com fulminante eficácia ex tunc faz abstração da evidência de que a implementação de uma nova ordem constitucional não é um fato instantâneo, mas um processo" (STF, RE 147.776/SP, 1. ' T., rel. MIN. SEPÚlVEDA PERTENCE, j. 19/05/1998, DJ 19/06/1998). 
"ao declarar a inconstitucionalidade de lei ou ato normativo, e tendo em vista razões de segurança jurídica ou de excepcional interesse social, poderá o Supremo Tribunal Federal, por maioria de dois terços de seus membros, restringir os efeitos daquela declaração ou decidir que ela só tenha eficácia a partir de seu trânsito em julgado ou de outro momento que venha a ser fixado".

Como se vê, por razões de segurança jurídica ou de excepcional interesse social, o STF está autorizado a modular ou calibrar os efeitos da declaração de inconstitucionalidade, excepcionando a regra da retroatividade (ex tunc). GILMAR FERREIRA MENDES ensina que

"[o] princípio da nulidade continua a ser a regra no direito brasileiro. O afastamento de sua incidência dependerá de um severo juízo de ponderação que, tendo em vista análise fundada no princípio da proporcionalidade, faça prevalecer a ideia de segurança jurídica ou outro princípio constitucionalmente relevante, manifestado sob a forma de interesse social relevante" 231 .

Nesses casos, o vício reconhecido, que nada mais é que uma nulidade por violação do texto constitucional que afeta não apenas o ato objeto da demanda, mas todos os atos semelhantes (erga omnes), poderá surtir efeitos prospectivos, ou seja, para o futuro, de acordo com a modulação decidida pelo Supremo. Trata-se, portanto, de definir os marcos temporais da eficácia decorrente da nulidade reconhecida.

Não se ignora a controvérsia sobre a constitucionalidade dos dispositivos citados e seu âmbito de aplicação ${ }^{232}$. Segundo alguns, a norma é inconstitucional diante da reserva

\footnotetext{
${ }^{231}$ Controle abstrato de constitucionalidade: ADI, ADC e ADO, p. 647.

${ }^{232}$ Sintetizada, essa controvérsia, por AlESSANDRA PIGNATARI, extraindo-se elementos do voto do Min. CELSO DE MELLO, relator do AgRg no RE 395.902/RJ, j. 07/03/2006, DJ 25/08/2006 (ob. cit., p. 98-99). Vale trazer a ementa: "RECURSO EXTRAORDINÁRIO INTERPOSTO PELO MUNICÍPIO DO RIO DE JANEIRO/RJ - PLEITO RECURSAL QUE BUSCA A APLICAÇÃO, NO CASO, DA TÉCNICA DA MODULAÇÃO DOS EFEITOS TEMPORAIS DA DECLARAÇÃO DE INCONSTITUCIONALIDADE IMPOSSIBILIDADE, PELO FATO DE O SUPREMO TRIBUNAL FEDERAL NÃO HAVER PROFERIDO DECISÃO DE INCONSTITUCIONALIDADE PERTINENTE AO ATO ESTATAL QUESTIONADO - JULGAMENTO DA SUPREMA CORTE QUE SE LIMITOU A FORMULAR, NA ESPÉCIE, MERO JUÍZO NEGATIVO DE RECEPÇÃO - NÃO-RECEPÇÃO E INCONSTITUCIONALIDADE: NOÇÕES CONCEITUAIS QUE NÃO SE CONFUNDEM - RECURSO IMPROVIDO. 1. CONSIDERAÇÕES SOBRE O VALOR DO ATO INCONSTITUCIONAL - OS DIVERSOS GRAUS DE INVALIDADE DO ATO EM CONFLITO COM A CONSTITUIÇÃO: ATO INEXISTENTE? ATO NULO? ATO ANULÁVEL (COM EFICÁCIA EX TUNC OU COM EFICÁCIA EX NUNC)? - FORMULAÇÕES TEÓRICAS - O STATUS QUAESTIONIS NA JURISPRUDÊNCIA DO SUPREMO TRIBUNAL FEDERAL. 2. MODULAÇÃO TEMPORAL DOS EFEITOS DA DECISÃO DE INCONSTITUCIONALIDADE: TÉCNICA INAPLICÁVEL QUANDO SE TRATAR DE JUÍZO NEGATIVO DE RECEPÇÃO DE ATOS PRÉ-CONSTITUCIONAIS. - A declaração de inconstitucionalidade reveste-se, ordinariamente, de eficácia 'ex tunc' (RTJ 146/461-462 - RTJ 164/506509), retroagindo ao momento em que editado o ato estatal reconhecido inconstitucional pelo Supremo Tribunal Federal. - O Supremo Tribunal Federal tem reconhecido, excepcionalmente, a possibilidade de
} 
da Constituição para regular a matéria, havendo necessidade de tal se dar por emenda constitucional $^{233}$; para outros, somente é possível modular efeitos de decisão tomada em sede de controle concentrado. E uma terceira corrente aceita aplicar tal permissivo em qualquer caso de declaração de inconstitucionalidade, reconhecendo nessa aplicação uma faceta do fenômeno da "objetivação do controle difuso de constitucionalidade", antes já mencionado $^{234}$.

GILMAR MENDES, partidário da terceira corrente, lembra que "não parece haver dúvida de que a limitação de efeito é apanágio do controle judicial de constitucionalidade, podendo ser aplicado tanto no controle direto quanto no controle incidental". Citando doutrina de RUI MEDEIROS, o autor ensina ainda que, "embora tenha surgido no contexto das alterações jurisprudenciais de precedentes, a prospectivity tem integral aplicação às hipóteses de mudança de orientação que leve à declaração de inconstitucionalidade de uma lei antes considerada constitucional" 235 .

Forçoso reconhecer que o Supremo Tribunal Federal tem aceitado a limitação temporal de efeitos tanto em sede de controle concentrado como em hipóteses de controle difuso, muito embora, nesses casos, dada a natural limitação da eficácia vinculante das decisões, a modulação acabe valendo apenas para o caso concreto ${ }^{236}$.

proceder à modulação ou limitação temporal dos efeitos da declaração de inconstitucionalidade, mesmo quando proferida, por esta Corte, em sede de controle difuso. Precedente: RE 197.917/SP, rel. MIN. MAURÍCIO CORRÊA (Pleno). - Revela-se inaplicável, no entanto, a teoria da limitação temporal dos efeitos, se e quando o Supremo Tribunal Federal, ao julgar determinada causa, nesta formular juízo negativo de recepção, por entender que certa lei pré-constitucional mostra-se materialmente incompatível com normas constitucionais a ela supervenientes. - A não-recepção de ato estatal pré-constitucional, por não implicar a declaração de sua inconstitucionalidade - mas o reconhecimento de sua pura e simples revogação (RTJ 143/355 - RTJ 145/339) -, descaracteriza um dos pressupostos indispensáveis à utilização da técnica da modulação temporal, que supõe, para incidir, dentre outros elementos, a necessária existência de um juízo de inconstitucionalidade. - Inaplicabilidade, ao caso em exame, da técnica da modulação dos efeitos, por tratarse de diploma legislativo, que, editado em 1984, não foi recepcionado, no ponto concernente à norma questionada, pelo vigente ordenamento constitucional.

${ }^{233}$ PIgNATARI, ob. cit., p. 100. Essa a principal razão da inconstitucionalidade apontada nas ADIns 2154 e 2258, ambas da relatoria do MIN. DiAS TOFFOLI, sucedendo o MiN. SEPÚlVEDA PERTENCE, que já votou reconhecendo a inconstitucionalidade. Os processos estão na conclusão da MIN. CÁRMEN LúCIA desde 2007, em razão de pedido de vista.

234 A esse respeito, vale a leitura completa do acórdão da Rcl. 4335/AC, rel. MIN. GILMAR MENDES, j. 20/03/2014, DJe 23/10/2014, mas em especial os votos dos MINISTROSTEORI ZAVASCKI, ROBERTO BARRoso e CELSO de MELlo.

${ }^{235}$ Jurisdição Constitucional, p. 398 e 400.Segundo o autor, "talvez um dos temas mais ricos da teoria do direito e da moderna teoria constitucional seja aquele relativo à evolução jurisprudencial e, especialmente, a possível mutação constitucional. Se a sua repercussão no plano material é inegável, são inúmeros os desafios no plano do processo em geral e, em especial, do processo constitucional” (p. 407).

${ }^{236}$ Caso citado na doutrina é o RE 197.917, no qual se reconheceu a inconstitucionalidade do artigo $6 .^{\circ}$ da Lei Orgânica do Município de Mira-Estrela, em razão de ter fixado seu número de vereadores em afronta ao 
Parece-nos, todavia, equivocado que a modulação de efeitos, nesses casos de alteração da jurisprudência antes consolidada da Corte, abarque o próprio caso concreto que está sendo julgado e os demais casos já jurisdicionalizados. Tratando-se de variação da interpretação do direito posto, em muito devida exatamente às partes que levaram a questão até o Supremo Tribunal Federal, buscando o bem da vida que as instâncias ordinárias, eventualmente, negaram, não faz sentido algum que a tutela jurisdicional seja negada quando o fundamento principal de seu pedido foi acatado pelo Supremo.

A justificativa para a atribuição de efeitos prospectivos a uma decisão que reconhece a inconstitucionalidade se deve muito mais a razões políticas que jurídicas. Sob o argumento de proteger a segurança jurídica e a estabilidade das relações, o Judiciário acaba por cobrar do jurisdicionado a conta pela morosidade da entrega da tutela jurisdicional. Se, por um lado, em sede de controle abstrato, pode até ser aceitável tutelar situações consolidadas no tempo, sob a ponderação feita entre o dano de desconstituí-las e o decorrente da própria existência da inconstitucionalidade declarada, no controle concreto e difuso, não há justificativa para que a parte que levou a questão ao Judiciário seja penalizada por ter sido o seu caso o selecionado como paradigma.

Recentemente $^{237}$, o Supremo reconheceu a inconstitucionalidade do art. $23, \S 5 .^{\circ}$, da Lei 8.036/1990, e do art. 55 do Decreto 99.684/1990, na parte em que ressalvam o "privilégio do FGTS à prescrição trintenária", haja vista violarem o disposto no art. 7., XXIX, da Carta de 1988. Quanto à modulação, o Tribunal, por maioria, atribuiu à decisão efeitos ex nunc, vencido o Ministro Marco Aurélio Mello, que não modulava os efeitos. Ao analisar o caso, o Supremo declarou a inconstitucionalidade das normas que previam a prescrição trintenária. No caso dos autos, o recurso foi interposto pelo Banco do Brasil contra acórdão do Tribunal Superior do Trabalho (TST) que reconheceu ser de 30

disposto no artigo 29, IV, da CF. Consta da ementa do acórdão: “[...] Inconstitucionalidade, incidenter tantun, da lei local que fixou em 11 (onze) o número de Vereadores, dado que sua população de pouco mais de 2600 habitantes somente comporta 09 representantes. 8. Efeitos. Princípio da segurança jurídica. Situação excepcional em que a declaração de nulidade, com seus normais efeitos ex tunc, resultaria grave ameaça a todo o sistema legislativo vigente. Prevalência do interesse público para assegurar, em caráter de exceção, efeitos pro futuro à declaração incidental de inconstitucionalidade. Recurso extraordinário conhecido e em parte provido" (RE 197.917/SP, rel. MIN. MAURícIO CORRÊA, j. 06/06/2002, DJ 07/05/2004). A propósito desse caso, ainda, como bem aponta ARAKEN DE ASSIS (Manual dos Recursos, p. 814), é evidente que o STF formulou uma regra jurídica abstrata, ainda que tenha, posteriormente, se recusado a aplicar essa tese a caso similar (AgR na Recl. 3.051/RS, Plenário, rel. MIN. CARLOS BRITTO, DJe 15/09/2006).

${ }^{237}$ Notícia veiculada no sítio eletrônico do STF no dia 13/11/2014, consultada no dia 21/11/2014 (disponível em: $<$ http://www.stf.jus.br/portal/cms/verNoticiaDetalhe.asp?idConteudo $=279716 \&$ caixaBusca $=\mathrm{N}>$ ). Tratase do ARE 709.212/DF, rel. Min. GILMAR MENDES, j. 13/11/2014. 
anos o prazo prescricional relativo à cobrança de valores não depositados do FGTS, em conformidade com a Súmula 362 daquela corte.

Segundo o relator, Ministro GILMAR MENDES, a jurisprudência do STF

"não se apresentava concorde com a ordem constitucional vigente quando entendia ser o prazo prescricional trintenário aplicável aos casos de recolhimento e de não recolhimento do FGTS. Isso porque o art. 7. ${ }^{\circ}$, XXIX, da Constituição de 1988 contém determinação expressa acerca do prazo prescricional aplicável à propositura das ações atinentes a 'créditos resultantes das relações de trabalho"”.

Com esse argumento, foi proposta uma alteração de jurisprudência, que foi aceita pela maioria do Plenário, a qual, mantido o entendimento consolidado a respeito da natureza de direito trabalhista dos recolhimentos ao Fundo de Garantia por Tempo de Serviço, passou a entender que, em decorrência dessa natureza, o prazo deveria seguir o disposto no artigo 7. ${ }^{\circ}, \mathrm{XXIX}$, da CF/1988.Entretanto, diante da mudança a ser operada em antiga jurisprudência do Supremo Tribunal Federal, “com base em razões de segurança jurídica”, o Ministro GiLmar Mendes defendeu que os efeitos da decisão fossem "modulados no tempo, a fim de que se concedam apenas efeitos prospectivos à decisão e à mudança de orientação" proposta no voto. Desse modo, o Tribunal aplicou a seguinte fórmula:

"para aqueles cujo termo inicial da prescrição ocorra após a data do presente julgamento, aplica-se, desde logo, o prazo de cinco anos. Por outro lado, para os casos em que o prazo prescricional já esteja em curso, aplica-se o que ocorrer primeiro: 30 anos, contados do termo inicial, ou 5 anos, a partir desta decisão".

Com esse resultado, o recorrente do caso julgado com repercussão geral ganhou mas não levou, pois embora sua tese tenha sido aprovada pelo tribunal, não obteve o bem da vida que tanto buscou no processo. Tal entendimento - que em muito decorre da promiscuidade existente entre as regras do controle abstrato e as do controle concreto de constitucionalidade $^{238}$-, transforma o litigante em mero veículo de teses, desprezando

\footnotetext{
${ }^{238}$ CAPPELLETTI é claro ao diferenciar ambos os sistemas com relação à natureza do vício de inconstitucionalidade. Enquanto para o sistema norte-americano, a lei inconstitucional é considerada absolutamente nula (null and void) e, por isso, ineficaz, pelo que "o juiz, que exerce o poder de controle, não anula, mas, meramente, declara uma (pré-existente) nulidade da lei inconstitucional", no sistema austríaco, ao contrário, "a Corte Constitucional não declara uma nulidade, mas anula, cassa ('aufhebt') uma lei que, até o momento em que o pronunciamento da Corte não seja publicado, é válida e eficaz, posto que inconstitucional". E prossegue tratando da Corte Constitucional austríaca, para lembrar que detém o "poder discricionário de dispor que a anulação da lei opere somente a partir de uma determinada data posterior à publicação ('Kundmachung') de seu pronunciamento, contanto que esse diferimento da eficácia
} 
outra função do processo, mesmo em sede de recursos extraordinários, de estrito direito: a tutela jurisdicional do direito da parte. No caso, o que o Banco do Brasil sempre buscou foi a reforma do julgado pelo reconhecimento da inconstitucionalidade; não faz sentido que, acolhida sua causa de pedir, seu pedido seja rejeitado, por razões que dizem respeito à faceta pública desse tipo de recurso, ou seja, aos efeitos que extrapolaram o direito das partes debatido na causa ${ }^{239}$.

\subsection{Reclamação para controlar a aplicação de súmula vinculante ${ }^{240}$}

Já foi dito antes que a técnica processual vem sendo reformada com o propósito de tornar a tutela jurisdicional mais efetiva e justa, para o que é necessário que seja tempestiva. O acúmulo de processos, em especial nas Cortes superiores, tem sido apontado como responsável pela demora na prestação jurisdicional. No intuito de otimizar o funcionamento do Supremo Tribunal Federal, a Emenda Constitucional 45/2004, atendendo a clamor antigo de seus Ministros, passou a prever a possibilidade de edição pelo STF de súmulas com efeito vinculante.

Todavia, ainda que a imensa fragmentação de julgados presente na realidade brasileira comprometa os grandes ideais da boa justiça tão valorizados pela força vinculante dosholdings do sistema anglo-saxão - igualdade, segurança, economia e respeitabilidade -, é muito importante não perder de vista os elementos distintivos dos sistemas decommon law e civil law. Daí não ser dado ignorar que

constitutivado pronunciamento não seja superior a um ano" (Controle judicial de constitucionalidade das leis no direito comparado, p. 115-116).

239 Nesses casos, imprescindível distinguir a norma jurídica (ratio decidendi) da norma individual (dispositivo), como ensina Jaldemiro Rodrigues de ATAÍDE JÚNIOR: “[...] pode-se afirmar que dos precedentes dos tribunais superiores, geralmente, deriva uma norma jurídica geral e irretroativa, que deve repercutir sobre o julgamento de inúmeros outros casos, e uma norma individual, concreta e retroativa, já que deve regular os atos e fatos do caso em questão" (ob. cit., p. 176).

${ }^{240}$ Embora seja inegável que, em linguagem científica, é imperioso preferir a palavra, termo ou expressão no sentido original mais próximo, do qual surgiu a figura de linguagem, é possível admitir o uso, por construção legítima (metonímia), da palavra "súmula" em lugar de "verbete da súmula", em especial por decorrência de seu uso corrente e, mais precisamente, por sua adoção pelo próprio texto da Constituição Federal. Mas vale mencionar a crítica externada por José CARLOS BARBOSA MOREIRA ao tratar do tema no seio da análise da Emenda Constitucional 45/2004: "[...] a palavra 'súmula' sempre se empregou - em perfeita consonância com a etimologia e os dicionários - para designar o conjunto das proposições em que se resume a jurisprudência firme de cada tribunal, a começar pela Corte Suprema, onde ela foi criada em 1963, sob a denominação de Súmula da Jurisprudência Dominante (no singular), com a qual se incorporou ao Regimento Interno"(A Emenda Constitucional n. 45 e o processo, in: Temas de direito processual, nona série, p.25-26). 
"a força vinculante dos holdings constitui fator inerente ao sistema da common law, como ponte de passagem entre os princípios gerais do direito e cada um dos casos concretos a serem objeto de julgamento. [...] uma máxima colocada como holding traz em si mesma uma imperatividade que não está presente em outras nem nas considerações integrantes do que se chama dictum" 241 .

Especificamente quanto às súmulas vinculantes, Elival DA SiLva RAMOS, reconhecendo sua natureza normativa e as assemelhando, cum grano salis, aos regulamentos de execução, ressalta que a aprovação desses verbetes pelo Supremo Tribunal Federal consiste em "uma atividade de produção normativa com características próprias, mas que, seguramente, se posiciona em nível subalterno à Constituição e à legislação infraconstitucional"242.

O constituinte derivado, cauteloso, ao criar a possibilidade de o Supremo Tribunal Federal emitir verbetes sumulares de efeito vinculante, achou por bem impor-lhes certas condições, dentre as quais sobressai a necessidade de ter havido, antes, "reiteradas decisões sobre matéria constitucional", ou seja, é preciso que o verbete seja a conclusão do Tribunal sobre questão por ele já reiteradamente discutida. Ainda, o §1..$^{\circ}$ do artigo 103-A define o que pode ser objeto da súmula:

"a validade, a interpretação e a eficácia de normas determinadas, acerca das quais haja controvérsia atual entre órgãos judiciários ou entre esses e a administração pública que acarrete grave insegurança jurídica e relevante multiplicação de processos sobre questão idêntica".

O STF, portanto, cria Direito tanto quanto todo e qualquer órgão do Poder Judiciário ao interpretar e aplicar um texto normativo oriundo do Legislativo ${ }^{243}$. Todavia, embora

\footnotetext{
${ }^{241}$ Essa vinculação, portanto, vai além da "mera influência que no plano puramente psíquico alguns precedentes particularmente prestigiosos exercem sobre o espírito dos juízes para julgamentos futuros", lembrando, o autor, a necessária distinção entre "influência" e "poder", já que aquela apenas sugere comportamentos, sem imperatividade inerente àquele (DINAMARCO, Súmulas vinculantes, p. 217-218).

${ }^{242}$ Embora afirme que a criação do instituto pelo constituinte derivado de 2004 não ofende ao disposto no artigo 60, § 4. ${ }^{\circ}$, III, da Constituição, o autor o critica sem peias, por não atender nenhum dos fins que teriam justificado sua criação (Controle de constitucionalidade no Brasil: perspectivas de evolução, p. 376 e 379$381)$.

${ }^{243}$ CAPPELLETTI explica que "[o] verdadeiro problema, porquanto, não é o da clara oposição, na realidade inexistente, entre os conceitos de interpretação e criação do direito. O verdadeiro problema é outro, ou seja, o do grau de criatividade e dos modos, limites e aceitabilidade da criação do direito por obra dos tribunais judiciários". Mais à frente na sua argumentação, aponta os elementos que, para ele, não apenas distinguem os processos jurisdicionais de criação do Direito dos demais como são a sua "grande e única força": a inércia da Jurisdição ("virtudes passivas") e o devido processo legal ("limites processuais") (Juízes legisladores?, p. 21 e 73-81).
} 
indiscutível a natureza normativa dos verbetes vinculantes ${ }^{244}$ - ademais, como já eram as decisões tomadas em sede de controle concentrado de constitucionalidade, com a distinção de que a edição do verbete, ainda que tenha de cumprir o rigoroso procedimento previsto no artigo 103-A, pode-se dar de ofício -, é importante ressaltar que se trata texto normativo produto da interpretação ${ }^{245}$.

CAPPELlETTI, em clássica distinção que fez entre a atividade legislativa e a jurisdicional, enfatiza que esta deve, necessariamente, referir casos concretos; não havendo essa conexão, os juízes estarão operando competência legislativa ${ }^{246}$. Em outra passagem, o autor lembra que o direito jurisprudencial demanda uma cristalização pela aplicação rígida da regra do stare decisis; caso contrário, terá um potencial de "flexibilidade, de concretude e de adaptabilidade às circunstâncias imprevisíveis do caso maior que o direito legislativo" 247 . A distinção é importante para fins de aplicação do sistema processual de controle dos atos judiciais.

Mas a reforma não parou por aí. À parte o saudável regime estipulado para o processo de criação, alteração e revogação dos verbetes vinculantes, o constituinte derivado se viu premido a estabelecer um mecanismo ágil e eficaz para garantir seu fiel cumprimento - imbuído, talvez, da intenção de mostrar aos críticos temerosos que não havia motivo para alarde ${ }^{248}$.

\footnotetext{
${ }^{244}$ Há quem defenda, com base nessa mesma premissa e diferenciando as súmulas não vinculantes dos vinculantes, a possibilidade de ajuizamento de ação rescisória de julgado que infrinja algum destes (COSTA MAIA, "Violação à súmula vinculante e cabimento de rescisória", p. 243). No mesmo sentido, BARBOSA MoreIRA, Comentários ao Código de Processo Civil, p. 135. Sob um aspecto, não seria absurdo dizer que as decisões judiciais vinculantes com força de lei são mais imunes de controle que a própria lei, pois não estão sujeitas ao controle difuso de constitucionalidade. Com efeito, se todo o Judiciário deve seguir a ratio decidendi fixada pelo Supremo Tribunal Federal, é vedada a análise da constitucionalidade dessa norma, por mais ilógico que seja cogitar de o próprio guardião da Constituição decidir de modo contrário a seus desígnios.

${ }^{245}$ Como ensina DiNAMARCO, "[n]o sistema de súmulas com eficácia vinculante é indispensável a consciência dos modos como elas se relacionam com a Constituição e a lei na ordem jurídico-positiva e em face da hierarquia das fontes formais do direito. Para tanto, o ponto de partida é a consideração do caráter normativo das súmulas. Elas são, como dito, portadoras de normas específicas em relação às normas mais genéricas e abstratas contidas nos textos da Constituição Federal" (Súmulas vinculantes, p. 240).

${ }^{246}$ Ob. cit., p. 80-81. Da mesma forma, já se pronunciou BOTELHO DE MESQUITA (A súmula da jurisprudência predominante no Supremo Tribunal Federal, in: Teses, estudos e pareceres de processo civil, v. 2, p. 219). ${ }^{247}$ Ob. cit., p. 85.

${ }^{248}$ TIAGO ASFOR ROCHA LIMA, para quem, "[h]odiernamente, parece inconcebível que uma autoridade administrativa possa escancarada e sistematicamente descumprir decisões que foram objeto de debate exaustivo no Supremo Tribunal Federal a ponto de serem incluídas como enunciados sumulares"(Precedentes judiciais civis no Brasil, p. 46).Essa afirmativa alvissareira leva a crer em que o inconcebível, se despido de otimismo e encartado na realidade do foro, com o auxílio da técnica equivocada, pode, sim, ser concebido no Brasil.
} 
Nessa contingência, dada a previsão já existente na Constituição Federal de utilização da reclamação para "garantia da autoridade" das decisões do STF e do STJ, parece ter sido até automático cogitar de lhe atribuir mais essa funcionalidade. Curioso notar que essa novel hipótese parece ter despertado os advogados para o fato de que a reclamação, mesmo antes da EC45/2004, já poderia ser usada em casos de descumprimento de precedente emanado do controle concentrado de constitucionalidade, pois que tais decisórios já eram dotados de eficácia erga omnes e vinculante.

Por fim, como exemplo, entendemos interessante analisar alguns julgados relativos à Súmula Vinculante 10, cuja observância tem gerado grande dificuldade e um número enorme de reclamações. Eis o que estabelece o verbete: "viola a cláusula de reserva de plenário (CF, artigo 97) a decisão de órgão fracionário de tribunal que, embora não declare expressamente a inconstitucionalidade de lei ou ato normativo do Poder Público, afasta sua incidência, no todo ou em parte".

Recentemente, suposta violação à referida súmula serviu de fundamento para reclamação na qual se alegou que o TRT da 13. ${ }^{a}$ Região contrariou a decisão do STF no Recurso Extraordinário 586.543/SE ao afirmar que "o contrato de previdência integra o contrato de trabalho do empregado"; destacou-se que essa súmula não se aplica a toda e qualquer hipótese em que a autoridade judiciária deixa de acolher a pretensão da parte de fazer incidir determinada norma ao caso concreto em debate, mas se refere exclusivamente à hipótese em que se afasta a incidência de lei ou ato normativo por fundamento constitucional. Além disso, reclamação com fundamento nesse enunciado não temo condão de corrigir a atuação dos demais órgãos do Poder Judiciário eventualmente em desconformidade com a Constituição Federal, ressalvado o desrespeito ao artigo97 da $\mathrm{CF} / 1988^{249}$.

Em outra oportunidade, o tribunal assentou que a simples ausência de aplicação de uma dada norma jurídica ao caso sob exame não caracteriza violação da orientação firmada pelo Supremo Tribunal Federal, já que, para caracterizar contrariedade à Súmula Vinculante 10, é necessário que a decisão fundamente-se na incompatibilidade entre a norma legal tomada como base dos argumentos expostos na ação e a Constituição. Na hipótese, o Superior Tribunal de Justiça não declarou a inconstitucionalidade nem afastou a

${ }^{249}$ Rcl. 16618 AgR/PB, rel. MIN. DIAS TOFFOLI, 1. ${ }^{\text {a }}$ T., j. 04/11/2014, DJe 21/11/2014. 
incidência dos dispositivos elencados (arts. 273, §2. ${ }^{\circ}$, e 475-O, do Código de Processo Civil e do art. 115 da Lei 8.213/1991), restringindo-se a considerá-los inaplicáveis ao $\operatorname{caso}^{250}$.

Tem-se afirmado, também, que a violação à Súmula Vinculante 10 não pode se dar no julgamento de medida cautelar, sendo desnecessário aplicar a cláusula de reserva de plenário nesses casos, em franca utilização da reclamação como meio de interpretação não apenas da norma contida na súmula, mas também da própria norma constitucional ${ }^{251}$. Essa mesma utilização se verifica em outro julgado, no qual o tribunal decidiu que o artigo 93, XI, da Constituição não atinge o sistema dos juizados especiais (art. 98, I), os quais, pela configuração atribuída pelo legislador, não funcionam, na esfera recursal, sob regime de plenário ou de órgão especial. As Turmas Recursais, órgãos colegiados desses juizados, podem, portanto, sem ofensa ao art. 97 da Constituição e à Súmula Vinculante 10, decidir sobre a constitucionalidade ou não de preceitos normativos ${ }^{252}$.

Com relação ao objeto da declaração de inconstitucionalidade, o STF se pronunciou contrário à aplicação da Súmula Vinculante 10 quando se tratar de norma préconstitucional, que poderá ser afastada em recorrência da incompatibilidade com as normas constitucionais supervenientes ${ }^{253}$. Por outro lado, já se julgou procedente reclamação por reconhecer que o afastamento do regime sucessório legal previsto aos companheiros, sob o pretexto de dar harmônica interpretação à legislação infraconstitucional, e invocando a igualdade substancial entre união estável e casamento, acabou por negar vigência ao artigo 1.790 do Código Civil, sem a devida observância da cláusula de reserva do plenário, em clara afronta à segunda parte da Súmula Vinculante $10^{254}$.

Também reconhecendo violação à súmula aqui tratada, com base no artigo161, parágrafo único, do Regimento Interno do STF, julgou-se procedente a reclamação, para não apenas cassar o acórdão reclamado, mas ainda com a determinação de que fosse “devolvido o prazo ao Ministério Público, com intimação pessoal e mediante remessa dos

\footnotetext{
${ }^{250}$ Rcl. 6.944, rel. MIN. CÁRMEN LÚCIA, Pleno, j. 23/06/2010, DJe de 13/08/2010. No mesmo sentido: RE 628.267 AgRrel. MIN. ROSA WEBER, 1. ${ }^{\mathrm{a}}$ T., j. 05/11/2013, DJe de 21/11/2013.

${ }^{251}$ Rcl. 10.864 AgR, rel. MIN. CÁRMEN LÚCIA, j. 24/03/2011, DJe de 13/04.2011. No mesmo sentido: Rcl. 14.956, rel. MIN. MARCO AURÉLIO, decisão monocrática, DJe de 19/12/2012; Rcl. 14.195, rel. MIN. ROSA WEBER, decisão monocrática, DJe 18/10/2012; Rcl. 8.848 AgR, rel. MIN. CÁRMEN LÚCIA, Pleno, j. 17/11/2011, DJe 1.\%/12/2011;Rcl. 16738 AgR/PE, rel. Min. CÁRMEN LÚCIA, Pleno, Dje 28/04/2014.

${ }^{252}$ ARE 792.562 AgR, rel. MIN. TEORI ZAVASCKI, 2. ${ }^{a}$ T., j.18/03/2014, DJe de 02/04/2014.

${ }^{253} \mathrm{Rcl}$ 15.786 AgR, rel. MIN. RICARDO LEWANDOWISKI, Pleno, j. 18/12/2013, DJe de 19/02/2014.

${ }^{254}$ Rcl. 18896/SP, rel. MIN. ROBERTO BARROSO, j. 30/10/2014, DJe 04/11/2014.
} 
autos" $^{\text {,255 }}$. Verifica-se, portanto, que, além de analisar o mérito da reclamatória, o relator decidiu a respeito do mérito do recurso, cuja solução foi objeto da reclamação (agravo regimental interposto contra a decisão do relator que indeferiu pedido o MP para ser intimado pessoalmente, fundada em copiosos precedentes do STJ) e também do recurso extraordinário interposto também contra a mesma decisão objeto da reclamação ${ }^{256}$.

\subsubsection{A limitação probatória}

Um ponto que merece reflexão são os limites probatórios no processo de reclamação, em especial naquelas hipóteses de alegada violação de súmula vinculante e sempre que se cogitar de seu cabimento contra ato não jurisdicional ${ }^{257}$.

Em um primeiro momento, pode parecer que a verificação de contrariedade ao precedente prescinda da produção de outros meios de prova além do documental. Mas daí a impedir que a parte demonstre sua alegação por outros meios, como, por exemplo, o

255،DIREITO PROCESSUAL PENAL. INTIMAÇÃO DO MINISTÉRIO PÚBLICO. LEI ESPECIAL. AFASTAMENTO. VIOLAÇÃO DA CLÁUSULA DE RESERVA DE PLENÁRIO. 1. A Quinta Turma do Superior Tribunal de Justiça afastou normas expressas (art. 18, II, 'h', da Lei Complementar 75/93, bem como o art. 41, IV, da Lei 8.625/93) que garantem ao Ministério Público a intimação nos autos, sob fundamento de ofensa ao princípio da isonomia. 2. Viola a cláusula de reserva de plenário (CF, artigo 97) a decisão de órgão fracionário de tribunal que, embora não declare expressamente a inconstitucionalidade de lei ou ato normativo do poder público, afasta sua incidência, no todo ou em parte (súmula vinculante n. 10). 3. Há, em relação ao Ministério Público, uma prerrogativa de ser intimado pessoalmente e com vista dos autos, para qualquer finalidade. Ou seja, não basta a intimação pessoal. Ademais, a LC n. 75/93 e a Lei $n^{\circ}$ 8.625/93 são leis especiais e não preveem formas diferenciadas de intimação, de modo que não é aplicável a intimação pessoal (por meio de mandado) prevista na lei geral. Com efeito, não há nessa interpretação nenhuma violação ao princípio da isonomia, uma vez que a intimação, de todo modo, não deve ficar à discrição do membro do Ministério Público. 3. Reclamação julgada procedente" (Rcl. 17694/RS, rel. MIN. ROBERTO BARROSO, j. 30/09/2014, DJe 07/10/2014). Essa decisão nos foi enviada, com perplexidade, pelo amigo e professor DANIEL PENTEADO DE CASTRO, a quem agradeço a sugestão do debate.

${ }^{256} \mathrm{STJ}$, Ag. 1.012.567/RS, rel. MiN. MARCO AURÉLIO BelliZZE, 5. ${ }^{\mathrm{a}} \mathrm{T}$. Trata-se de agravo contra decisão que não admitiu o recurso especial interposto pelo MP. Vale lembrar que o pedido formulado será o de desconstituição do ato reclamado para que, se for o caso, o Supremo Tribunal Federal determine a feitura de outro, nos termos da súmula violada. No tocante ao objeto dessa espécie de reclamação, CASSIO SCARPINELLA BUENO encontra um ponto de contato com o recurso extraordinário: "Contrariar a súmula vinculante (ou, como quer o caput do dispositivo em exame, "negar vigência") deve ser entendido como a situação em que o ato da Administração (direta ou indireta de qualquer nível federado) ou a decisão judicial (de qualquer órgão jurisdicional) deixar de observar o que foi estatuído por ela. Trata-se, em última análise, de situação similar àquela que autoriza, com base no art.102, III, 'a', da Constituição Federal, recurso extraordinário, o que viabiliza a extração e aplicação do próprio entendimento consolidado no Supremo Tribunal Federal acerca da interpretação daquele dispositivo para os fins aqui examinados" (Curso sistematizado de direito processual civil, v. V, p. 424).

${ }^{257}$ A jurisprudência do STF é no sentido da impossibilidade de se rediscutir, em sede de reclamação, a matéria fático-probatória debatida no processo no qual foi prolatada a decisão reclamada (Rcl. 3.342/AP, rel. MIN. SEPÚlVEDA PERTENCE; Rcl. 4.272/RS, rel. MIN. CELSODE MELLO; Rcl. 4.733/MT, rel. MIN. CEZAR PELUSO; Rcl. 3.375-AgR/PI, rel. MIN.GILMAR MENDES; Rcl. 12758 AgR/DF, rel. MIN. LUIZ FUX, j. 24/04/2013, DJe 27/09/2013). 
testemunhal, vai uma distância muito grande.

Em algumas hipóteses, a limitação das provas contrariará o que, segundo a maioria, é a própria razão de ser da reclamação constitucional: a possibilidade de chegar direto aos tribunais superiores. Será possível até cogitar de caso em que, a depender do entendimento perfilhado, o reclamante ficará privado da tutela jurisdicional.

Que o direito à prova é ínsito ao devido processo legal, não se discute. CÂNDIDO RANGEL DiNAMARCo afirma que, na Constituição, o direito à prova é inerência do conjunto de garantias do justo processo e se consubstancia na liberdade de acesso às fontes e meios segundo o disposto em lei e sem restrições que maculem ou descaracterizem o justo processo $^{258}$. Assim, quando a Constituição garante o devido processo legal e o contraditório, está garantindo um feixe extenso de direitos que tornem possível e efetiva a concretização do acesso à ordem jurídica justa.

Como se sabe, o parágrafo único do artigo 13 da Lei 8.038/1990 é expresso em afirmar que a reclamação será "instruída com prova documental”. Do mesmo modo, vem escrito o parágrafo único do artigo 156 do RISTF e o parágrafo único do artigo 187do RISTJ. A Lei 11.417/2006, como afirmado antes, nada dispõe sobre o procedimento da reclamação que prevê em seu artigo 7. . A propósito, curioso notar o rigor de ambos os tribunais, os quais, embora adotem a tese de se tratar de ação constitucional ${ }^{259}$, não aplicam às reclamações o disposto no artigo 284 do CPC, que prevê o dever de o juiz determinar a emenda da inicial, caso não venha instruída devidamente ${ }^{260}$. Também o artigo 985 do novo Código de Processo Civil, na última versão publicada antes da sua aprovação pelo

\footnotetext{
${ }^{258}$ Instituições de direito processual civil, v. III, p.47. Para JOSÉ ROBERTO DOS SANTOS BEDAQUE, "contraditório efetivo e defesa ampla compreendem o poder conferido à parte, de se valer de todos os meios de prova possíveis e adequados à reconstrução dos fatos" (Garantia da amplitude da produção probatória, p. $168)$.

${ }^{259}$ Ressalvada a hipótese prevista na Resolução $12 / 09$ do STJ e tratada no item 4.1 acima, cuja natureza recursal é reconhecida pelo STJ, ao menos para dificultar sua admissão. Confira-se: "Consoante jurisprudência do STJ, não é possível a emenda da petição inicial das reclamações ajuizadas no STJ, com amparo na Resolução 12/2009, em razão de sua natureza jurídica recursal. 2. Ademais, a reclamação apoiada na Resolução 12/2009 é admitida para dirimir divergência entre a jurisprudência do STJ e acórdão prolatado por Turma Recursal Estadual, o caso em tela não se amolda a essa hipótese, pois se pretende a cassação de

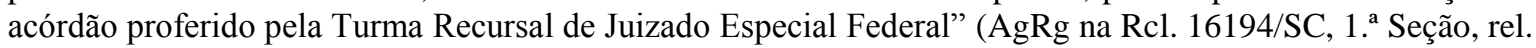
MiN. MAURO CAMPBELl MARQUES, j. 26/03/2014, DJe 02/04/2014).

${ }^{260}$ Não se admite sua juntada nem sequer em sede de agravo regimental. Veja-se: "Inviável a juntada, em sede de agravo regimental, de peças consideradas essenciais à instrução da reclamação" (AgRg na Rcl. 18.385/SP, 3. ${ }^{a}$ S., rel. Min. Regina Helena Costa, j. 27/08/2014, DJe 4/9/14). No mesmo sentido: Rcl. 13.313/DF, 3. ${ }^{a}$ S., rel. MiN. RogÉRIO SCHIETTI, DJe de 29/05/2014; e RCDESP na Rcl. 3.965/SP, rel. MIN. LuIS FeliPe Salomão, 2. ${ }^{a}$ S., j. 25/8/2010, DJe 31/08/2010. No STF: Rcl. 12.999/DF, rel. Min. LuiZ FuX, DJe de 10/04/2014; e Rcl. 11.837/MG, rel. Min. CÁRMEN LúCIA, DJe de 16/06/2011.
} 
Congresso, prevê, no §2. ${ }^{\circ}$, que a reclamação deverá ser instruída com prova documental.

A pouca doutrina que já se debruçou sobre o instituto da reclamação dedica ao seu procedimento menos de um décimo de suas preocupações; com relação às provas, partindo da premissa quase verdade absoluta de que se trata de procedimento idêntico ao do mandado de segurança, é ela ainda mais parcimoniosa.

Não se pode retirar toda razão dos que assim pensam, em especial se considerarmos, como fazemos neste item, apenas as reclamações que visam a fulminar decisões judiciais violadoras de súmula vinculante. Com efeito, tais reclamatórias, aparentemente, pouco ou nada se diferenciam do mandado de segurança impetrado com vistas a anular ato judicial viciado contra o qual não caiba recurso.

Todavia, um dado já mencionado antes parece vir sendo desprezado pela doutrina: o fato de essa hipótese de reclamação constitucional ${ }^{261}$ ser de competência exclusiva do Supremo Tribunal Federal. Em outras palavras, por expressa previsão constitucional e legal, por enquanto, somente o STF pode analisar demanda que verse pedido de desconstituição de ato administrativo ou jurisdicional tomado ao arrepio do comando sumular vinculante. Trata-se de competência funcional constitucional, portanto absoluta $(\text { art.111 do CPC) })^{262}$.

Essa premissa, somada à orientação prevalecente de que só se admite prova préconstituída, leva à conclusão de que, não existindo essa prova, o reclamante não terá a alternativa - sempre indicada em sede de mandado de segurança - de se socorrer das chamadas "vias ordinárias", pois haveria flagrante incompetência de qualquer outro órgão jurisdicional na análise da compatibilidade direta do ato com o verbete vinculante. Nesse ponto, o novo Código de Processo Civil, se a última versão tiver sido a aprovada, não altera essa conclusão, pois a reclamação para fazer valer as súmulas vinculantes continua sendo de competência exclusiva do Supremo, já que a lei não pode alterar o texto constitucional.

\footnotetext{
${ }^{261}$ Lembrando a ADIn 2.212-1, relatada pela MIN. ELLEN GRACIE, cuja decisão concluiu pela constitucionalidade das reclamações previstas nas Constituições Estaduais para salvaguarda dos julgados e da competência dos tribunais locais, com base no argumento de que se trataria de exercício do direito de petição, dada a natureza não jurisdicional da reclamação. Por isso, temos que apenas a reclamação prevista no artigo 103-A, $\S 3^{\circ}$, da $\mathrm{CF} / 88$, continua sendo exclusividade do $\mathrm{STF}$, já que ainda não existem verbetes sumulares vinculantes de outros tribunais.

${ }^{262}$ PIZZOL,A competência no processo civil, p. 151 e 251.
} 
Não se pode aceitar a compreensão de que a análise da confrontação direta entre o enunciado sumular e o ato que se alega violá-lo possa ser feita principaliter por qualquer juízo. Não é isso que a Constituição prevê e seria mesmo, até que surja entendimento diverso do próprio Supremo Tribunal Federal, frontal violação da competência funcional do órgão máximo do Poder Judiciário. Evidente que a norma contida no verbete pode ser usada como fundamento para eventual recurso, mas jamais como causa de pedir de uma demanda ajuizada perante o juízo competente para contrastar o ato reclamado.

Mesmo que não se aceite essa conclusão ou se a aceite com ressalvas - pois, quando se trata de decisão judicial, é possível imaginar o cabimento de recurso ou de algum instrumento que lhe faça as vezes - é inegável que nos casos em que a causa de pedir veicule um ato administrativo, por não haver a possibilidade de ser impugnado a não ser via demanda própria, esta demanda só poderá ser a reclamatória constitucional.

E, em ambas as hipóteses, não parece ser possível a impetração de mandado de segurança segundo regras de competência comum, pois se estaria violando a competência exclusiva do Supremo Tribunal Federal. O artigo 7. ${ }^{\circ}$ da Lei da Súmula Vinculante é claro ao afirmar que é cabível a reclamação "sem prejuízo dos recursos ou outros meios admissíveis de impugnação", o que poderia abrir ensejo a uma interpretação alargada para se entender que a expressão "outros meios admissíveis de impugnação" englobaria outras ações perante outros juízos. Entretanto, corre-se o risco de resvalar em inconstitucionalidade, já que o artigo 103-A da CF/1988 não traz essa possibilidade de forma expressa.

Em que pese a natureza normativa das súmulas vinculantes, quis o constituinte que o guardião de seu cumprimento fosse o seu emitente, seu criador. Talvez, até por se tratar de fonte normativa oriunda de precedentes, somente ao próprio Supremo Tribunal Federal seja dado analisar condutas contrastantes ao que preveem tais normas. Nessas circunstâncias, seria possível a lei ordinária transferir a outros órgãos judiciários essa competência, equiparando as súmulas vinculantes a dispositivos legais em geral?

Evidentemente, considerando que os verbetes tratam da "validade, interpretação ou eficácia" de normas determinadas perante a Constituição Federal, todo e qualquer órgão do Poder Judiciário e, de resto, dos demais Poderes, poderá interpretar referida norma (cuja análise originou a súmula vinculante) de acordo ou em desacordo com a interpretação dada 
pelo Supremo Tribunal Federal ${ }^{263}$, emitindo daí um ato. Contra tal ato, pode ser interposto o recurso cabível ou, se for o caso, impetrado um mandado de segurança - ou, ainda, a depender das circunstâncias, apresentada uma reclamação correicional perante o órgão hierarquicamente superior.

Todavia, a reclamação prevista no artigo 103-A, §3. ${ }^{\circ}$, cujo pedido é a desconstituição do ato para que outro seja proferido "com ou sem a aplicação da súmula", só pode ser ajuizada perante o Supremo Tribunal Federal. Nessa linha de argumentação, o problema da limitação probatória se agrava sobremodo nos casos em que a demanda ataca ato administrativo, parecendo decorrência lógica do devido processo legal a aceitação de outros meios de prova eventualmente produzidos no decorrer do procedimento ou delegáveis pelo Supremo Tribunal Federal a outros juízos.

Destarte, diversamente do que ocorre com os mandados de segurança impetráveis contra atos ilegais, hipótese em que a limitação procedimental à prova pré-constituída se justifica pelo fato de ser possível ao impetrante se valer das "vias ordinárias" em caso de necessidade de produzir outras provas, tratando-se de pedido reclamatório, voltado à fulminação do ato infringente do verbete com "força de lei", tais vias não estão disponíveis, pois não há previsão constitucional dessa competência originária do STF.

Objeto da prova, segundo doutrina de CÂNDIDO RANGEL DinAmarCo ${ }^{264}$, é o conjunto de alegações controvertidas das partes em relação a fatos relevantes para todos os julgamentos a serem feitos no processo. É, portanto, sobre os fatos que recairá toda a atividade probatória realizada no processo. Salvo exceções previstas no artigo 337 do CPC, o direito não é objeto de prova, já que iura novit curia.

O objeto da prova na reclamação aforada contra ato estatal violador de súmula não difere dos demais, ou seja, há de se compor pelas alegações de fato apresentadas pelas

\footnotetext{
${ }^{263}$ Nos dizeres de SANDRO KOZIKOSKI, “[...] a decisão judicial que contrarie ou negue vigência a texto da Constituição é impugnável pelos meios ordinários colocados à disposição das partes. No entanto, a decisão que desprestigie o entendimento sumulado em caráter vinculante (que não se subsume, necessariamente, aos contornos do texto positivado da Constituição) é atacável por reclamação dirigida diretamente ao STF. Em última análise, a sistemática impugnativa traçada para resguardar a eficácia das súmulas vinculantes não guardou parâmetros de proporcionalidade com o sistema recursal pátrio, eis que a reclamação poderá ser intentada per saltum" (As súmulas vinculantes..., p.1206). Neste mesmo sentido, RODOLFO DE CAMARGO MANCuSO, Divergência jurisprudencial e súmula vinculante, p. 407 e 425, para quem, a "interpretação" da súmula vinculante "não se vocaciona ao mesmo elastério a que se sujeitam as normas legais, pela razão de que aquele enunciado já constituiu o extrato de reiterados julgamentos do STF sobre uma dada matéria, onde o tema foi exaustivamente debatido, até alcançar um consenso, extratificado no verbete" (p. 407).

${ }^{264}$ Instituições..., v. III, p. 57.
} 
partes e feitas controvertidas no processo. Assim, por exemplo, se o reclamante se voltar contra a nomeação de um funcionário público alegando a violação da Súmula $13^{265}$, deverá provar que os fatos alegados se conformam à realidade; no caso, provar que o nomeado se enquadra na proibição estabelecida no verbete. Perceba-se que não se trata mais de questionar a contratação em face da lei ou da Constituição Federal. O texto normativo que servirá de tipo é o próprio enunciado sumular vinculante.

Nesse passo, convém lembrar, no tocante às hipóteses em que o ato impugnado na reclamação não é judicial, que dois conhecidos atributos do ato administrativo possuem relação direta com a instrução do processo do qual tais atos sejam objeto: a presunção de legitimidade e de validade. Segundo MARIA SYLVIA ZANELlA Di PIETRO ${ }^{266}$, a primeira “diz respeito à conformidade do ato com a lei; em decorrência desse atributo, presumem-se, até prova em contrário, que os atos administrativos foram emitidos com observância da lei”. Já a presunção de veracidade diz respeito aos fatos; em decorrência desse atributo, "presumem-se verdadeiros os fatos alegados pela Administração, cujas certidões, atestados, declarações e demais atos informativos são dotados da chamada 'fé pública',267.

Alguns casos podem ser pensados. Suponhamos que o STF decida por transformar o entendimento atual a respeito da constitucionalidade do artigo 73 da Lei 8.666/1993 em súmula de seguinte teor: "é constitucional o artigo 73 da Lei 8.666/1993, desde que o ente da Administração contratante não tenha agido com culpa in vigilando" ${ }^{\text {268 }}$. O reclamante, então, deverá comprovar as alegações de fato tendentes a levar o tribunal à conclusão de que o verbete fora aplicado de forma indevida. Como então não permitir às partes a produção de todos os meios de prova, especialmente voltados à verificação de ocorrência

\footnotetext{
265، A nomeação de cônjuge, companheiro ou parente em linha reta, colateral ou por afinidade, até o terceiro grau, inclusive, da autoridade nomeante ou de servidor da mesma pessoa jurídica investido em cargo de direção, chefia ou assessoramento, para o exercício de cargo em comissão ou de confiança ou, ainda, de função gratificada na Administração Pública Direta e Indireta em qualquer dos Poderes da União, dos Estados, do Distrito Federal e dos Municípios, compreendido o ajuste mediante designações recíprocas, viola a Constituição Federal".

${ }^{266}$ Ob. cit., p. 182.

${ }^{267}$ É verdade que é preciso ler a doutrina administrativista, nesse ponto, com certa reserva, pois, na prática, se tem visto, cada vez mais, a desconsideração completa desses atributos do ato administrativo, sendo constante o tratamento isonômico das partes do ponto de vista do direito probatório, ainda que uma delas seja a Administração Pública. Fica a questão de se saber se, nessas hipóteses, há, de fato, isonomia, ou se se deveriam levar em consideração referidos atributos dos atos administrativos, pois que essenciais à realização da própria finalidade da Administração, que é administrar e executar os objetivos constitucionais estabelecidos no artigo $3 .^{\circ}$ da CF.

${ }^{268}$ Veja-se, a propósito, o acórdão que julgou a ADC 16/DF, rel. MIN. CEZAR PELuSO, j. 24/11/2010, um voto vencido.
} 
da conduta culposa exigida pelo verbete hipotético? ${ }^{269}$

Outra hipótese ventilada diz com o descumprimento do Súmula Vinculante $11^{270}$. Apesar de ser matéria de direito penal, a ensejar a impetração de habeas corpus com espeque na lei ou em algum específico dispositivo constitucional, qualquer interessado poderá - se duradoura a violação - ajuizar reclamação perante o STF, devendo - e, antes de tudo, podendo - fazer prova de suas alegações. Trata-se, repita-se, de ação constitucional de natureza civil específica, cabível para tutelar todo e qualquer tipo de violação à interpretação sumulada.

Também não colhe frutos alegar que a exigência de prévia instância administrativa (art.7. ${ }^{\circ}, \S 1 .^{\circ}$, da Lei 11.417/2006) como condição para o conhecimento da reclamação contra ato administrativo tornará quase uma ficção a necessidade de ampliar o espectro de meios de prova. A despeito da evidente inconstitucionalidade do dispositivo, a existência de um processo administrativo anterior não significa que, nesta seara, todas as provas já foram produzidas e que, portanto, bastaria instruir a inicial com cópias dos autos

\footnotetext{
${ }^{269}$ Ao julgar o AgR na Rcl. 12758/DF, que tratou exatamente de hipótese em que o acórdão reclamado, proferido pelo TST, estaria infringindo o quanto decidido na ADC 16/DF, embora o STF tenha refirmado o entendimento de que não é possível discutir, em sede de reclamação, não é possível fazer a análise do material fático-probatório debatido nos autos, durante os debates, os Ministros demonstraram sua preocupação com o tema bem como que, na prática, fazem, sim, a análise dos processos para saberem se há ou não elementos comprobatórios de que a Administração Pública não agiu com culpa in vigilando ou in eligendo, situações que, nos termos do precedente paradigma, trazem de volta a responsabilidade pelas obrigações trabalhistas, excluída pelo artigo 71 da Lei Federal 8.666/1993, declarado constitucional com na referida ADC (Pleno, rel. MIN. LUIZ FUX, j. 24/04/2013, DJe 27/09/2013).

270 "Só é lícito o uso de algemas em casos de resistência e de fundado receio de fuga ou de perigo à integridade física própria ou alheia, por parte do preso ou de terceiros, justificada a excepcionalidade por escrito, sob pena de responsabilidade disciplinar, civil e penal do agente ou da autoridade e de nulidade da prisão ou do ato processual a que se refere, sem prejuízo da responsabilidade civil do estado". Há precedente julgando improcedente a reclamação por falta de prova do uso indevido de algemas, com a seguinte ementa: RECLAMAÇÃO. PROCESSO PENAL. USO DE ALGEMA. ALEGAÇÃO DE CONTRARIEDADE À SÚMULA VINCULANTE N. 11 DO SUPREMO TRIBUNAL FEDERAL. PEDIDO DE REVOGAÇÃO DA PRISÃO CAUTELAR. AUSÊNCIA DE DETERMINAÇÃO JUDICIAL PARA O USO DE ALGEMAS. FALTA DE PROVA DA ALEGAÇÃO DE USO DE ALGEMA. RECLAMAÇÃO JULGADA IMPROCEDENTE. 1. Dispõe a Súmula Vinculante n. 11 que "Só é lícito o uso de algemas em casos de resistência e de fundado receio de fuga ou de perigo à integridade física própria ou alheia, por parte do preso ou de terceiros, justificada a excepcionalidade por escrito, sob pena de responsabilidade disciplinar, civil e penal do agente ou da autoridade e de nulidade da prisão ou do ato processual a que se refere, sem prejuízo da responsabilidade civil do estado". 2. Na espécie vertente, o juiz Reclamado apenas autorizou o uso de algemas, sem, contudo, determiná-lo, e deixou a decisão sobre a sua necessidade, ou não, à discrição da autoridade policial que efetivamente cumpriria o mandado de prisão, tendo em vista as circunstâncias do momento da diligência, acentuando a necessidade de acatamento da Súmula Vinculante n. 11 deste Supremo Tribunal. 3. Os documentos colacionados aos autos não comprovam o uso de algemas durante, ou após, a diligência que resultou na prisão do Reclamante, sendo certo que, se usadas, elas não o foram por determinação do ato reclamado. 4. Reclamação julgada improcedente (STF, Rcl. 7814/RJ, Pleno, rel. MIN. CÁRMEN LÚCIA, j. 27/05/2010, DJe 19/08/2010).
} 
$\operatorname{administrativos}^{271}$.

É muito comum, aliás, os interessados se socorrerem do Poder Judiciário diante da impossibilidade de produção de prova no seio do processo administrativo. Em casos que tais, como procederá o sujeito interessado no cumprimento do verbete? Precisará, antes, ajuizar um mandado de segurança para garantir seu direito à produção probatória para, só então, provas produzidas a contento, ato mantido pela Administração (contra a dicção do verbete vinculante, segundo a óptica do interessado), aviar a reclamação "documentada" para o Supremo?

Se essa for a solução - exigir prévia instauração de processo judicial - , toda a ligeireza elogiada na reclamação cairá por terra. Por outro lado, se não for assim, como o interessado conseguirá se utilizar dessa ação constitucional, para o que, segundo a doutrina, deverá se valer, apenas e tão só, de prova pré-constituída.

Com relação aos meios de prova cabíveis, a lei regulamentadora do artigo 103-A da CF/1988,dando sinal de que é imperioso refletir a respeito da adequação do regime estabelecido pela Lei 8.038/1990 a essa nova hipótese da reclamação constitucional, nada menciona a respeito. Ocorre que, até o momento, o STF vem aplicando às cegas, indistintamente, ambos os diplomas legais de forma complementar, aproveitando todas as previsões que, segundo sua óptica, podem ser aproveitadas. É o que ocorre com relação aos meios de prova.

Segundo visto, o parágrafo único do artigo 13 da Lei 8.038/1990 é expresso em afirmar que a reclamação será instruída com prova documental. Poder-se-ia aduzir que essa previsão não exclui a aplicação subsidiária do procedimento comum ordinário, que seria princípio lógico do sistema processual, dado que deflui de princípio comezinho de interpretação e aplicação da lei, além de estar previsto, expressis verbis, no Código de Processo Civil (art.272, par. ún.). Ocorre que a subsidiariedade pressupõe lacuna quanto à

${ }^{271}$ Esse, contudo, não é o entendimento do STF: CONSTITUCIONAL. AGRAVO REGIMENTAL EM RECLAMAÇÃO. AJUIZAMENTO CONTRA OMISSÃO DA ADMINISTRAÇÃO PÚBLICA. ALEGAÇÃO DE DESRESPEITO À SÚMULA VINCULANTE $16 . \quad$ NECESSIDADE DE ESGOTAMENTO DAS VIAS ADMINISTRATIVAS. LEI 11.417/2006. 1. Não se admite reclamação contra omissão da Administração Pública, sob fundamento de ofensa a súmula vinculante, quando não demonstrado o esgotamento das vias administrativas, conforme disposto no art. 7. ${ }^{\circ}, \S 1 .^{\circ}$, da Lei 11.417/2006. 2. Agravo regimental a que se nega provimento (Rcl. 14343 AgR/CE, rel. MIN. TEORI ZAVASCKI, j. 27/02/2014, DJe 28/03/2014). 
técnica que se pretende aplicar subsidiariamente. Não é, portanto, o que ocorre no caso, já que a lei que regulamenta o procedimento da reclamação é expressa ao tratar da necessidade de apresentar a prova documental com a inicial.

Essa expressa restrição, todavia, poderia ser encarada como dispositivo inócuo, ante a própria natureza da prova documental e da técnica de sua produção, diante de ditames modernos de economia e eficiência do processo. Não parece mesmo de todo desarrazoado supor que as partes, no primeiro momento de se apresentarem nos autos, deveriam apresentar todos os elementos de prova de que porventura já disponham, sob pena de preclusão. Essa, ademais, era a intenção do Código de Processo Civil, ao dispor que compete à parte instruir a petição inicial ou a resposta com os documentos destinados a provar-lhe as alegações (art.396), com as exceções previstas nos artigos 355, 360, 397 e $399^{272}$. Mas a jurisprudência tem, indevidamente, segundo pensamos ${ }^{273}$, abrandado essa regra, na contramão das correntes mais atuais inspiradas na eficiência da prestação da tutela jurisdicional e no sistema regulador da boa-fé processual (arts.14 a 18 do CPC), a grave dano da marcha regular do processo ${ }^{274}$.

Entretanto, mesmo compreendida a restrição como mera regra de reforço do sistema, a produção de outras provas no desenrolar do procedimento seria de difícil realização, pois também não há qualquer menção à audiência ou ao momento adequado para a oitiva de testemunhas, por exemplo, e tampouco referência à prova pericial quer na lei quer em normas regimentais ${ }^{275}$.

\footnotetext{
${ }^{272}$ Além de outras situações eventualmente previstas na lei (cfr. ANTONIO CARLOS ARAúJo CinTRA, Comentários..., p. 148).

${ }^{273}$ No mesmo sentido, CASSIO SCARPINELLA BUENO, lembra que "a práxis forense admite que os documentos sejam apresentados a qualquer momento do processo sem observância dos pressupostos do art. 397”, para, em seguida, com mais entusiasmo, expressar sua não adesão a essa prática "porque ela conspira contra o 'modelo constitucional do processo civil', especificamente contra o disposto no art. $5^{\circ}$, LXXVIII, da Constituição Federal" (Curso sistematizado de direito processual civil, v. 2, tomo I, p.321).

${ }^{274}$ Cfr. acórdãos colacionados por THeOtONIO NeGRãoet al., Código de Processo Civil e legislação processual civil em vigor, 44. ed., nota 1 ao artigo 397, p. 488.

${ }^{275}$ Não se olvide que tem sido comum, a fim de instruir os processos de controle concentrado de constitucionalidade, a realização de audiências públicas multidisciplinares com múltiplos representantes, além da participação de amicus curiae, cada vez mais incrementada nesses processos de índole coletiva. O STF já determinou a realização de audiência em sede de reclamação (Rcl. 16535/RJ, rel. MIN. LUIZ FuX, decisão liminar de 15/10/2013, DJe 17/10/2013). Na espécie, alegou-se o descumprimento da decisão do relator que, em sede de agravo regimental em RE, determinou o sobrestamento dos feitos que cuidassem da matéria cuja repercussão geral havia sido reconhecida. O relator da reclamação, MIN. LUIZ FuX, em decisão que foge aos parâmetros ordinários, apesar de reconhecer não haver similitude entre o paradigma apontado e a decisão reclamada, com base no princípio da instrumentalidade e em razão da "relevância constitucional e social da matéria", resolveu substituir ex officio o paradigma apontado pelo reclamante pela decisão tomada
} 
CÂNDIDO RANGEl DinAmarco é enfático ao afirmar que não se pode escolher o procedimento, mas apenas o processo ${ }^{276}$. De fato, considerando que as regras procedimentais visam a dar segurança às situações jurídicas que sucedem na relação processual, apesar de já haver quem defenda a possibilidade de flexibilização, é mesmo natural que o sistema queira preestabelecê-las e não dar margem a que as partes ou o juiz possam com elas transigir.

Também é de conhecimento que o procedimento comum ordinário é aquele definido pelo sistema processual como sendo o mais completo do ponto de vista da sequência de fases e atos previstos e de amplitude de oportunidades para as partes; por isso mesmo, é ele subsidiário $^{277}$. O que nem de longe significa dizer que os demais procedimentos sejam de qualidade inferior sob a óptica do devido processo legal. Em verdade, o sistema prevê outros procedimentos, diferenciados do comum ordinário, justamente porque este, em determinadas circunstâncias, levando em conta o direito objeto da demanda, mostra-se inadequado ${ }^{278}$. Questão de necessidade e economia: seria o mesmo que, considerando um triângulo retângulo qualquer, podendo-se percorrer a distância correspondente à hipotenusa, o sujeito fosse obrigado a percorrer os dois catetos. Ambos os trajetos levariam ao mesmo destino, mas não há razão para que um sistema que prima pela economia e pela busca incessante da eficiência estabelecesse a obrigatoriedade de trilhar o caminho mais longo.

Sabe-se, também, que, na busca dessa especialização dos procedimentos, de sua

no Mandado de Injunção 708, da relatoria do Min. Gilmar Mendes, que tratava do exercício do direito de greve por parte dos servidores públicos. Vale transcrever dois parágrafos da decisão liminar: "Do ponto de vista formal, verifico que o paradigma invocado pelo reclamante não se ajusta precisamente aos limites fático-jurídicos versados na presente demanda. Sem embargo, a relevância constitucional e social da matéria aqui tratada guarda estreita pertinência com o histórico pronunciamento do Supremo Tribunal Federal nos autos do Mandado de Injunção n. 708, rel. Min. Gilmar Mendes, oportunidade em que a Corte reconheceu a importância e resguardou a eficácia do direito de greve dos servidores públicos, ante a omissão regulamentar do Congresso Nacional. Nesse contexto, a visão instrumentalista do processo impõe a relativização pontual de nuances procedimentais de sorte a garantir a efetividade dos direitos, máxime daqueles já consagrados pelo Plenário do órgão máximo do Poder Judiciário nacional. Forte nessas razões, conheço a presente reclamação, tomando o julgado no Mandado de Injunção $\mathrm{n}^{\circ} 708$ como decisão afrontada pelo acórdão reclamado". Importa, para o tema aqui tratado, verificar que tem havido, nesse processo, considerável ampliação das possibilidades probatórias, a qual não faz sentido ser guardada apenas para situações tão excepcionais.

${ }^{276}$ Instituições de direito processual civil, v. II, p. 475-476.

${ }^{277}$ DinAMARCO, Instituições..., v. II, p.473.

${ }^{278}$ Afirma, a respeito, HeITOR VITOR MENDONÇA SICA, com espeque em ADROALDO FuRTADO FABRício, ser "absolutamente assente a ideia de que os procedimentos especiais só se justificam na medida em que houver a necessidade adequar regras inconvenientes ou insuficientes para a prestação jurisdicional eficiente em face das peculiaridades do direito material" (Reflexões em torno da teoria geral dos procedimentos especiais, item $3)$. 
adequação à tutela jurisdicional pleiteada e à complexidade do direito tratado no processo, o sistema também modula a cognição judicial, adaptando-a às circunstâncias previsíveis ${ }^{279}$. É comum a afirmação de que uma das características dos procedimentos especiais e das chamadas tutelas jurisdicionais diferenciadas é a restrição da cognição judicial, seja no plano da profundidade (vertical) seja no plano da amplitude (horizontal) ${ }^{280}$.

Segundo KazUO WATANABE, cognição é um ato de inteligência, consistente em considerar, analisar e valorar as alegações e as provas produzidas pelas partes, vale dizer, as questões de fato e de direito que são deduzidas no processo e cujo resultado é o alicerce do julgamento do objeto litigioso do processo $^{281}$. Neste conceito, está evidenciado o laço que há de existir entre a cognição e as provas: estas se produzem para aquela.

A atividade cognitiva do juiz tem por objeto principal as alegações das partes. Nesse sentido, a limitação à produção probatória gera, como consequência inafastável, a limitação da cognição e, se esta restrição não se configurar mera adequação ao direito material, mas, ao contrário, for causa suficiente a prejudicar as partes a bem de quem foi estabelecida, passará ela a não mais se justificar.

Entendemos que a limitação à cognição somente se justifica se se prestar à otimização do procedimento, com vistas à melhoria do resultado do processo $^{282}$; caso contrário, configurará afronta ao devido processo legal por tolher o constitucional direito à efetiva participação das partes na formação do convencimento do Estado-juiz ${ }^{283}$.

\footnotetext{
${ }^{279}$ DINAMARCO vê aí a consistência do "princípio da adaptabilidade, que orienta os procedimentos no sentido da útil aderência às peculiaridades e exigências de cada situação jurídico-substancial lamentada ou postulada" (Das ações típicas, p.483). Para BEDAQUE, "[a] técnica processual deve estar sempre a serviço dos resultados" (Efetividade do processo e técnica processual, p.114).

${ }^{280}$ Como ensina KAZUO WATANABE, "não se pode negar [...] a utilidade da cognição como uma técnica para a concepção de diferentes tipos de procedimento, com vistas à instrumentalidade do processo". Ela é, em suma, "importante técnica de adequação do processo à natureza do direito ou à peculiaridade da pretensão a ser tutelada" (Da cognição no processo civil, p.36). DiNAMARCO também aponta a cognição como elemento fundamental à especialização procedimental com vistas à adequação das tutelas diferenciadas. Para ele, aliás, "[t]utela jurisdicional diferenciada é a proteção concedida em via jurisdicional mediante meios processuais particularmente ágeis e com fundamento em uma cognição sumária" (Instituições..., v. III, p.768-770). No mesmo sentido, RICARDO DE BARROS LEONEL, Tutela jurisdicional diferenciada, p. 84.

${ }^{281}$ Ob. cit.,p.58-59.

${ }^{282}$ Nesses casos, como vimos falando, não há nem sequer propriamente limitação, mas, antes, mera e salutar adequação.

${ }^{283}$ TARUFFO, já no início dos anos oitenta do século passado, reputava incompreensível que a exigência de garantia do direito à prova permanecesse estranha à tábua de valores do legislador processual, "anche quando si manifesti l'intenzione di adeguare la disciplina del processo ai principi costituzionali", para criticar o projeto de reforma do código da época no qual não se encontrava um mínimo aceno a esse direito (Il diritto alla prova nel processo civile, p.115-116).
} 
Costuma-se, como lembrado, associar a reclamação constitucional e seu procedimento ao mandado de segurança. Tal aproximação, entretanto, não pode levar à aplicação automática da técnica deste writ constitucional à reclamação; a situação exige reflexão acurada ${ }^{284}$.

É muito comum, em casos de inexistência de "prova pré-constituída" ou de exigência de prova pericial, em razão de alegada complexidade da matéria tratada no mandamus, os juízes extinguirem o processo sem exame do mérito e "remeterem as partes às vias ordinárias". A respeito disso, DinAmARCo põe em destaque o fato de que a exclusão de modo absoluto da prova testemunhal e de qualquer perícia adquire legitimidade "pela ressalva de que a denegação do writ por falta de prova não é suscetível de tornar-se imutável por força da coisa julgada material”285.

Tem-se, cotidianamente, "negado seguimento" a reclamações por ausência da prova documental pré-constituída ${ }^{286}$, sem, contudo, "remeter os reclamantes às vias ordinárias"; talvez, pela constatação de que não há "vias ordinárias", não existe essa válvula de escape. Acaso houvesse, aliás, é de se indagar a quem competiria o julgamento dessa "ação ordinária"? Ao próprio STF?

Parece, entretanto, que tal alternativa não se vislumbra possível nas hipóteses da reclamação de que vimos tratando, se o reclamante não dispuser daquele elemento de prova necessário à comprovação de suas alegações. Conforme já se afirmou aqui, a competência fixada na Constituição Federal é óbice bastante para que outro órgão jurisdicional que não o Supremo Tribunal Federal julgue o pedido de anulação ou cassação do ato infrator da interpretação vinculante sumulada. Não sendo cabível, como é no mandado de segurança, a "remessa" do reclamante às vias ordinárias, deve-se concluir que todas as oportunidades a que têm direito as partes que veiculam demanda em procedimento ordinário deverão ser oferecidas ao reclamante (e à autoridade reclamada), sob pena de violação ao direito à ampla produção probatória, ínsito à garantia do due process of law.

\footnotetext{
${ }^{284}$ A propósito dessa aplicação automática, vale trazer a razão pela qual essa simbiose foi excluída do Projeto de novo Código de Processo Civil: "Indicar o procedimento do mandado de segurança trará difículdades na autoexecutoriedade das decisões nas hipóteses, inúmeras, em que não se admitem liminares" (do relatório do SENADOR VITAL DORÊGO, já mencionado antes, p. 179).

${ }^{285}$ Instituições de direito processual civil, v. III, p. 48.

${ }^{286}$ Rcl. 13495/SP, rel. MIN. AYRES BRITTO, j. 23/03/2012, DJe 300/3/2012; Rcl. 11837/MG, rel. MIN. CÁRMEN LÚCIA, j. 13/06/2011, DJe 16/06/2011.
} 
Adira-se outro argumento, que não pode ser desprezado. A disposição constitucional que prevê o cabimento da reclamação não traz qualquer restrição ao uso da reclamação e a seu procedimento, diversamente do que dispõe o artigo $5 .^{\circ}$, LXIX, ao prever o cabimento de mandado de segurança para proteger direito líquido e certo. Por esse motivo, a restrição (rectius: adaptação) feita pela lei ordinária e pela jurisprudência do STF de somente admitir prova documental ou pré-constituída apenas poderá se justificar caso não redunde em prejuízo da própria garantia constitucional ${ }^{287}$.

Em outras palavras: a exigência feita ao reclamante de aparelhar a petição inicial da reclamação com "prova documental”, sob pena de reconhecimento de carência de ação 288 ou até de improcedência, somada à impossibilidade de veicular o pedido específico de anulação do ato, viola as garantias do artigo 5. ${ }^{\circ}, \mathrm{XXXV}$, LIV e LV, da CF/1988. De outra forma, essa carência, inexistente outra via na qual seja possível supri-la, correria o risco de se perenizar.

Por fim, uma última palavra se faz necessária. Evidentemente, parece de todo patológico atribuir ao Supremo Tribunal Federal a competência exclusiva - senão a concorrente também - do controle direto do cumprimento das súmulas vinculantes. $\mathrm{O}$ constituinte reformador - e, na sua linha, a jurisprudência e a doutrina que defende a ampliação do uso da reclamação como mecanismo componente do arcabouço constitucional de controle de constitucionalidade - parece não ter percebido que tal previsão acabará por trocar a pletora de recursos extraordinários por semelhante quantidade de reclamações, com o agravante das peculiaridades do procedimento e da amplitude decorrente da própria natureza dessas ações. Para evitar essa patologia, imperioso prever expressamente o cabimento do mandamus para o controle da aplicação dos verbetes vinculantes, de acordo com as regras comuns de competência.

Toda a concentração e a objetivação desejáveis a um sistema de controle de

\footnotetext{
${ }^{287}$ Não se podem confundir a hipótese de o reclamante pretender produzir outras provas com os casos em que não há outras provas ou a prova documental é, de fato, suficiente. A propósito, "O art. 156, parágrafo único, do Regimento Interno do Supremo Tribunal Federal e o art. 13, parágrafo único, da Lei n. 8.038/1990 dispõem que a reclamação deverá ser instruída com prova documental. Faz-se necessária a juntada aos autos do inteiro teor da decisão reclamada para que se possa averiguar o que alegado. Sem dados que possam ser minimamente analisados para a ciência do que ocorreu no processo, a presente reclamação não pode ter seguimento, pois carente dos requisitos necessários. 5.Pelo exposto, nego seguimento à presente reclamação, ficando prejudicado, por óbvio, o requerimento de medida liminar (art. $21, \S 1 .^{\circ}$, do Regimento Interno do Supremo Tribunal Federal)" (Rcl. 11837/MG, rel. MIN. CÁRMEN LÚCIA, j. 13/06/2011, DJe 16/06/2011).

${ }^{288}$ Rcl. 13495/SP, rel. MIN. AYRES BRITTO, j. 23/03/2012, DJ02/04/2012; Rcl. 11901/SP, rel. MiN. DiAS TOFFOLI, j. 23/11/2011, DJ 25/11/2011.
} 
constitucionalidade valorizador do respeito aos precedentes se dissipa mais à frente, com a enxurrada de ações reclamatórias que a tendente jurisprudência do Supremo Tribunal Federal ainda vem de incentivar.

\subsection{Reclamação perante o STJ no microssistema dos Juizados Especiais}

Partindo do quanto já exposto neste trabalho, seria fácil supor que, em decorrência da ausência de efeito vinculante nas suas decisões, o Superior Tribunal de Justiça não aceitaria reclamações ajuizadas com objetivo de controlar seus precedentes, enquanto decisões veiculadoras de teses jurídicas. E, de fato, a jurisprudência pacífica desse tribunal interpretava a hipótese constitucional de forma muito restritiva, de modo a somente entender cabível reclamação quando ajuizada por uma das partes do processo no qual foi proferida a decisão descumprida (que não se amolda ao presente estudo) ${ }^{289}$.

Entretanto, um acórdão do Supremo Tribunal Federal deu ensejo a que o Tribunal passasse a admitir seu cabimento nos casos em que acórdão de Turma Recursal de Juizado Especial Estadual divergir de entendimento expresso em súmula ou em acórdão proferido sob o rito dos recursos especiais repetitivos (Resolução STJ 12/2009) ${ }^{290}$.

A primeira hipótese não interessa ao presente estudo, pois não se trata verdadeiramente de precedente vinculante, mas apenas de eficácia natural inerente à autoridade da coisa julgada ou, quando menos, inerente a toda decisão judicial. A segunda, que será aqui analisada, representa um acréscimo funcional à reclamação, que passa a ser

\footnotetext{
${ }^{289}$ Quando o STJ admite a reclamação proposta por aquele que faz parte da categoria profissional (ou classe), representada ou substituída por entidade associativa ou sindical, por ser diretamente favorecido pela eficácia da decisão coletiva positiva transitada em julgado, ou seja, nos casos de processos coletivos julgados em sede de recurso especial, também não estamos tratando de garantir a observância de tese jurídica. Esses julgados tratam da legitimidade natural para propor execução individual oriunda de ação coletiva. Em outras palavras, nessas hipóteses, a reclamação visa a garantir a efetividade da tutela jurisdicional do caso concreto, não funcionando como mecanismo de controle de precedentes. Por exemplo: STJ,Rcl. 2208/RJ, 3. ${ }^{\text {a }}$ S., rel. MIN. NEFI CORDEIRO, j. 24/09/2014, DJe 1. \%/10/2014.

${ }^{290}$ A propósito, confira-se: "A decisão agravada calcou-se em dois fundamentos suficientes, quais sejam: a) que a reclamante não foi parte interessada no julgado paradigma do STJ no REsp 980.140/MG, consoante o exige o art. 187 do RISTJ, para a reclamação constitucional do art. 105, I, 'f', da CF/88; e b) a questão jurídica objeto da reclamação não foi definida em súmula e nem foi decidida sob o rito do art. 543-C do CPC, conforme o exige a reclamação prevista na Resolução STJ n. 12/2009" (STJ - AgRg na Rcl. 19057/RS, 1. ${ }^{a}$ Seç., rel. Min. MAURo CAMPBell MARQUES, 27/08/2014, DJe 04/09/2014). Note-se que, mesmo não se tratando da hipótese prevista na citada Resolução 12/2009, o tribunal parece ter aceitado a tese de que somente se poderia cogitar de eficácia ultra partes relativamente a teses fixadas em verbete sumular ou em acórdão decidido sob o rito dos recursos repetitivos.
} 
utilizada como sucedâneo recursal voltado, sim, a garantir a eficácia das teses fixadas em súmulas e acórdãos proferidos em recursos especiais.

No julgamento de Embargos de Declaração no Recurso Extraordinário571.572, ocorrido em 26 de agosto de 2009, o Supremo Tribunal Federal decidiu que, por ser inadmissível o recurso especial contra as decisões proferidas pelas turmas recursais dos Juizados Especiais $^{291}$ e diante da inexistência de órgão uniformizador no âmbito dos juizados estaduais, circunstância que inviabiliza a aplicação da jurisprudência do STJ, seria cabível, em caráter excepcional, a reclamação prevista no art. 105, I, $f$, da Constituição Federal, para fazer prevalecer, até a criação da turma de uniformização dos juizados especiais estaduais, a jurisprudência do Superior Tribunal de Justiça na interpretação da legislação infraconstitucional ${ }^{292}$.

O intuito foi o de prevenir que o risco de manutenção de decisões divergentes quanto à interpretação da legislação federal gere insegurança jurídica e uma prestação

\footnotetext{
${ }^{291}$ Em tese, como se verá, não há razão para restringir o cabimento da reclamação apenas contra acórdãos das turmas recursais, pois sentenças dos juizados especiais também podem violar decisão do Superior Tribunal de Justiça.

292 "EMBARGOS DE DECLARAÇÃO. RECURSO EXTRAORDINÁRIO. AUSÊNCIA DE OMISSÃO NO ACÓRDÃO EMBARGADO. JURISPRUDÊNCIA DO SUPERIOR TRIBUNAL DE JUSTIÇA. APLICAÇÃO ÀS CONTROVÉRSIAS SUBMETIDAS AOS JUIZADOS ESPECIAIS ESTADUAIS. RECLAMAÇÃO PARA O SUPERIOR TRIBUNAL DE JUSTIÇA. CABIMENTO EXCEPCIONAL ENQUANTO NÃO CRIADO, POR LEI FEDERAL, O ÓRGÃO UNIFORMIZADOR. 1. No julgamento do recurso extraordinário interposto pela embargante, o Plenário desta Suprema Corte apreciou satisfatoriamente os pontos por ela questionados, tendo concluído: que constitui questão infraconstitucional a discriminação dos pulsos telefônicos excedentes nas contas telefônicas; que compete à Justiça Estadual a sua apreciação; e que é possível o julgamento da referida matéria no âmbito dos juizados em virtude da ausência de complexidade probatória. Não há, assim, qualquer omissão a ser sanada. 2. Quanto ao pedido de aplicação da jurisprudência do Superior Tribunal de Justiça, observe-se que aquela egrégia Corte foi incumbida pela Carta Magna da missão de uniformizar a interpretação da legislação infraconstitucional, embora seja inadmissível a interposição de recurso especial contra as decisões proferidas pelas turmas recursais dos juizados especiais. 3 . No âmbito federal, a Lei 10.259/2001 criou a Turma de Uniformização da Jurisprudência, que pode ser acionada quando a decisão da turma recursal contrariar a jurisprudência do STJ. É possível, ainda, a provocação dessa Corte Superior após o julgamento da matéria pela citada Turma de Uniformização. 4. Inexistência de órgão uniformizador no âmbito dos juizados estaduais, circunstância que inviabiliza a aplicação da jurisprudência do STJ. Risco de manutenção de decisões divergentes quanto à interpretação da legislação federal, gerando insegurança jurídica e uma prestação jurisdicional incompleta, em decorrência da inexistência de outro meio eficaz para resolvê-la. 5. Embargos declaratórios acolhidos apenas para declarar o cabimento, em caráter excepcional, da reclamação prevista no art. 105, I, $f$, da Constituição Federal, para fazer prevalecer, até a criação da turma de uniformização dos juizados especiais estaduais, a jurisprudência do Superior Tribunal de Justiça na interpretação da legislação infraconstitucional” (STF, RE 571.572 ED, rel. MIN. ELLEN GRACIE, j. 26/08/2009, DJe 27/11/2009). Curioso notar que nenhum voto levantou o argumento que permitiu, tantas vezes, o Supremo Tribunal Federal ampliar sua competência constitucional, como já mencionado acima: a teoria dos poderes implícitos. Por que, partindo da jurisprudência do próprio STF, não é razoável (ou constitucional) admitir que o tribunal cuja incumbência máxima seja uniformizar o direito federal tenha competência para cassar decisões que contrariem a interpretação que atribuiu à lei federal no objetivo de uniformizá-la?
} 
jurisdicional incompleta. E duas razões básicas levaram os Ministros do STF a permitir e recomendar o uso da reclamação contra decisões dos Juizados Especiais Estaduais: a ausência de previsão constitucional para o cabimento do recurso especial e a inexistência de órgão uniformizador da jurisprudência como existia no âmbito do microssistema federal $^{293}$. Por conta disso, era patente o risco de ocorrerem "decisões divergentes quanto à interpretação da legislação federal, gerando insegurança jurídica e uma prestação jurisdicional incompleta".

$\mathrm{Na}$ realidade, o Supremo decidiu por interpretar ampliativamente a hipótese de cabimento da reclamação prevista no artigo 105, I, $f$, da CF/1988, para que possa ser utilizada também no âmbito dos Juizados Especiais, em que pese o fato de não caber recurso especial das decisões emanadas desses órgãos. Em outras palavras, embora não caiba o recurso constitucional previsto para a uniformização da interpretação da legislação federal, por expressa disposição do artigo 105, III, o sistema deveria admitir outro mecanismo capaz de preservar a jurisprudência do Superior Tribunal de Justiça no que respeita à unidade da interpretação da lei federal.

Não é demais lembrar, nesse ponto, que a intepretação que o Supremo dá à hipótese do artigo 102, I, $l$, da CF/1988, ao contrário, é restritiva, pois não se aceita reclamação que não seja para salvaguardar decisões dotadas de efeito vinculante e eficácia erga omnes, não abarcando, pois, a "jurisprudência dominante", os verbetes sumulares persuasivos nem os acórdãos dados em julgamento de recursos extraordinários repetitivos.

A doutrina e até alguns ministros do próprio Superior Tribunal de Justiça criticaram a solução dada pelo Supremo, basicamente por entenderem que se estaria criando uma nova hipótese de recurso especial não prevista na Constituição Federal ou, quando menos, estabelecendo-se uma espécie nova de recurso contra as decisões tomadas no sistema dos juizados, contrariando, assim, a própria lógica de um microssistema para solução definitiva das causas de menor complexidade e os crimes de pequeno potencial ofensivo (art. 98 da

\footnotetext{
${ }^{293}$ Forte nessa limitação, a jurisprudência do STJ é pacífica: "PROCESSUAL CIVIL. RECLAMAÇÃO CONTRA DECISÃO DE TURMA DE JUIZADO ESPECIAL FEDERAL. IMPOSSIBILIDADE. 1. Não cabe a Reclamação prevista na Resolução STJ 12/2009 contra decisão proferida por Turma Recursal dos Juizados Especiais Federais, pois previstas hipóteses recursais específicas no art. 14 da Lei 10.259/2001. Nesse sentido: AgRg na Rcl. 7.764/SP, rel. Ministro Benedito Gonçalves, 1. ${ }^{a}$ S., DJe 30.10.2012; AgRg na Rcl. 5.510/DF, rel. Ministro Arnaldo Esteves Lima, Primeira Seção, DJe 17.6.2011; EDcl na Rcl. 5.932/SP, rel. Ministro Mauro Campbell Marques, Primeira Seção, DJe 29.5.2012; EDcl no AgRg na Rcl. 6.016/DF, rel. Ministro Humberto Martins, Primeira Seção, DJe 29.11.2011. 2. Agravo Regimental não provido" (AgRg na Rcl. 12.302/SP, 1. ${ }^{a}$ S., rel. Min. HERMAN BENJAMIN, DJe 16/09/2013).
} 
CF/1988). Aliás, essa premissa, de se tratar de hipótese na qual a reclamação possui natureza recursal, já é entendimento pacífico do STJ, utilizado, por exemplo, para se negar a possibilidade de emenda da inicial nesses $\operatorname{casos}^{294}$.

Dois casos são paradigmáticos relativamente às vozes opositoras surgidas no Superior Tribunal de Justiça. O acórdão da Rcl. 3692/RS e o voto do MinISTRO MASSAMI UYEDA, vencido, no julgamento da Rcl. 6721/MS.

O primeiro deles foi julgado pouco antes da publicação da Lei dos Juizados Especiais Estaduais, e foi relatado pelo Desembargador Convocado do TJAP, HONILDO AMARAL DE MELLO E CASTRO, de cujo relatório retira-se argumentação importante para a compreensão da controvérsia estabelecida no seio do Tribunal, verbis: "A despeito do recente entendimento do colendo Supremo Tribunal Federal, não há previsão constitucional para que o Superior Tribunal de Justiça julgue as reclamações propostas contra acórdão proferido por Turma Recursal de Juizado Especial Estadual, ainda que contrariem a jurisprudência deste Sodalício"295.

Na sequência, o relator expõe a principal razão pela qual não conhece da reclamação: a hipótese do art. 105, I, $f$, da CF não pode se alargada em sua estreita previsão, mesmo em razão da segurança jurídica por decisão do STF. Afirma não compreender como se possa alterar os limites da previsão constitucional por meio de jurisprudência, ainda que o objetivo perseguido - pacificação social - seja nobre. Além disso, no caso concreto, a

294 "DIREITO PROCESSUAL CIVIL. AGRAVO NA RECLAMAÇÃO. ACÓRDÃO DE TURMA RECURSAL. PEÇA ESSENCIAL. AUSÊNCIA. A reclamação contra julgado de Turma Recursal de Juizado Especial Cível e Criminal, que tem previsão na Resolução STJ n. 12/2009, se assemelha ao agravo de instrumento previsto no art. 544 do CPC no que pertine à sua formação, não sendo possível a abertura de prazo para a juntada posterior de peça essencial. Precedentes. Agravo não provido" (AgRg na Rcl. 5.752/PR, 2. ${ }^{a}$ S., rel. MIN. NANCY ANDRIGHI, DJe 30/06/2011). Interessante é notar que, neste caso, foi indeferida liminarmente a inicial, com base no parágrafo único do art. 284 do CPC, sem, contudo, se ter dado a oportunidade determinada pelo caput desse mesmo artigo. Mais recentemente: AgRg na Rcl. 16194/SC, $1^{\text {a }}$ Seção, rel. MiN. MAURO CAMPBELl MARQUES, j. 26/03/2014, DJe 02/04/2014. Este último acórdão revoga posição externada anteriormente pela $1 .{ }^{a}$ Seção, quando, por maioria, deu provimento ao agravo regimenal na Rcl. 5957/SP, rel. p/ acórdão MIN. CESAR ASFOR ROCHA, j. 09/11/2011, DJe 19/12/2011, decidindo pela possibilidade de emenda da inicial em razão de todas as reclamações possuírem natureza de ação; segundo o voto vencedor: "Entendo, com todas as vênias ao eminente Ministro Benedito Gonçalves, relator, que a reclamação, na verdade, não é um recurso, é um procedimento iniciado aqui no Tribunal, que tem autuação separada e livre distribuição, como as ações originárias. Não tem, com efeito, natureza recursal, devendo ser adotados no seu processamento os mesmos critérios que são conferidos a uma ação de competência originária". Prevalece, hoje, a noção de que a natureza dessa reclamação é recursal.

${ }^{295}$ STJ, Rcl. 3692/RS, 2. ${ }^{\text {a }}$ S., Rel. Min. Honildo Amaral De Mello E CaStro, j. 14/10/2009, DJe $03 / 11 / 2009$. 
matéria já estaria apanhada pela coisa julgada, o que já seria móvito suficiente para se não conhecer da reclamação.

Mas o voto traz trecho que merece ser aqui copiado, ao antever a solução que, meses depois, viria com a Lei dos Juizados da Fazenda:

"[a]o se criar os juizados especiais federais com fulcro nos princípios da Lei 9.099/95, pensou-se na área federal e se esqueceu da estadual, razão pela qual atribuiu-se-lhe importância ímpar, não concedida aos juizados estaduais, principalmente com relação às turmas de uniformização, esquecidos os seus autores que Estados como São Paulo, Minas Gerais, Rio Grande do Sul, etc...têm inúmeras '319' Turmas Recursais e cujos julgamentos deveriam estar uniformizados em relação ao Tribunal de Justiça do Estado-Membro, que respeitaria os entendimentos desta Colenda Corte, instância maior do direito infra-constitucional. Preservarse-ia o equilíbrio jurisprudencial de norte a sul, garantindo a segurança jurídica da pacificação social em temas relevantes, de repercussão ou multiplicador de processos".

Já depois da vigência da Lei dos Juizados da Fazenda Pública, em voto profundamente crítico à abertura dessa nova hipótese de cabimento da reclamação, o MiniSTRO MASSAMI UYEDA apresentou várias questões que, de fato, merecem reflexão. Em primeiro lugar, questionou o argumento da segurança jurídica, indagando:

“que segurança jurídica está transmitindo o Poder Judiciário ao atribuir competência ao Superior Tribunal de Justiça não elencada pelo Constituinte? Segurança Jurídica, na acepção da palavra, decorre da determinabilidade das leis e da proteção da confiança, consubstanciada na existência de normas estáveis e previsíveis quanto aos seus efeitos (Canotilho)"296.

Da mesma forma, aduz o ministro, que a ausência de recurso a um órgão nacional uniformizador da jurisprudência das Turmas Recursais Estaduais não significa negativa de

\footnotetext{
${ }^{296}$ Rcl. 6721/MT, 2. ${ }^{\text {a }}$ S., rel. MiN. MASSAMi UYEDA, rel. p/ acórdão MiN. NANCY ANDRIGHI, j. 23/11/2011, DJe 09/11/2012. Vale trazer a íntegra do voto vencido proferido no julgamento desse verdadeiro leading case a respeito dos limites de cabimento da hipótese ora aventada: "RECLAMAÇÃO - ACÓRDÃO PROFERIDO POR TURMA RECURSAL DE JUIZADO ESPECIAL - INCOMPETÊNCIA DO SUPERIOR TRIBUNAL DE JUSTIÇA - INICIAL LIMINARMENTE INDEFERIDA. 1. A reclamação tem, em sua essência, a função de fazer prevalecer, na hierarquia judiciária, o efetivo respeito aos pronunciamentos jurisdicionais, emanados de Tribunais Superiores, para o fim de resguardar a integralidade e a eficácia subordinante dos comandos que deles emergem, resultantes de processo subjetivo, cuja vinculação é adstrita às partes que dele efetivamente participaram. 2. Enquanto todos os esforços estão voltados para uma otimização da prestação jurisdicional, está-se criando mais um entrave para a efetividade dos julgados. 3. Não parece crível poder-se alargar a competência do Superior Tribunal de Justiça, em sede de embargos de declaração em recurso extraordinário que não abarcou a questão, tampouco que esse pronunciamento tenha força vinculante, igualando-o às decisões proferidas em ações diretas de inconstitucionalidade e às súmulas vinculantes. 4. É manifestamente incabível, por incompetência, as reclamações ofertadas neste Superior, contra julgados das Turmas Recursais dos Juizados Especiais Estaduais. 5. Inicial liminarmente indeferida”.
} 
prestação jurisdicional, até porque o inciso I do artigo 98 da Constituição Federal consignou a possibilidade de recurso das decisões proferidas pelos juizados especiais estaduais para turmas de juízes de primeiro grau. Além disso, afirma que abertura para reclamações nessa sede, estaria desvirtuando o âmago dos Juizados Especiais, os quais, como estatuído pela Constituição Federal, são "competentes para a conciliação, o julgamento e a execução das causas cíveis de menor complexidade e infrações de menor potencial ofensivo, mediante os procedimentos oral e sumaríssimo".

Além disso, segundo o Ministro, atribuir competência ao Superior Tribunal de Justiça para processar e julgar reclamações ofertadas contra decisões oriundas dos Juizados Especiais, sem sombra de dúvida, fere o direito constitucional da razoável duração do processo e da celeridade, ainda mais em face de um procedimento que constitucionalmente deve ser informal e rápido. Alerta, ainda, para o fato de que o tribunal não conseguiria fazer prevalecer o seu "entendimento pacificado" acerca de determinada questão; ao contrário, correrá o risco de cometer injustiças irreparáveis, isso porque,

"em razão do procedimento oral e da informalidade que rege os juizados especiais, em que se dispensa o relatório na sentença e se admite fundamentação sucinta em grau de recurso (artigos 38 e 46 da Lei n. 9.099/95), não será possível, ao Ministro Relator, identificar se, de fato, o decisum impugnado cinge-se ao caso paradigmático".

Adverte, também, o Ministro que a orientação traçada estaria travestindo a reclamação em recurso especial, mas, contudo, sem os seus requisitos, como a necessidade de prequestionamento, a impossibilidade de reexame do conjunto fático-probatório e da interpretação de cláusula contratual, a necessidade de impugnação específica dos fundamentos do acórdão recorrido, enfim, sem qualquer requisito de admissibilidade.

Por fim, conclamando os colegas a refletir sobre o grande número de processos que ingressarão no Tribunal depois de aceita a tese aqui em destaque ${ }^{297}$, conclui afirmando que

\footnotetext{
297 "Não se pode, também, deixar de consignar o número de reclamações ajuizadas, perante a Segunda Seção desta Corte, desde o reconhecimento da 'competência' do Superior Tribunal de Justiça para resguardar a integralidade e a eficácia subordinante das suas decisões frente aos julgados das Turmas Recursais dos Juizados Especiais Estaduais. De acórdão com a Gestão Estratégica deste Tribunal, em 2009, foram distribuídas 150 (cento e cinquenta) ações; em 2010, recebemos 829 (oitocentos e vinte e nove) processos; até o dia 6 de outubro de 2011, os componentes da Segunda Seção se depararam com 1.471 (um mil, quatrocentos e setenta e uma) reclamações. A manutenção das Reclamações perante o Superior Tribunal de Justiça contra ato dos Juizados Especiais Estaduais acabará por inviabilizar o funcionamento da Corte, em especial da Segunda Seção. Não há dúvida que a questão merece melhor análise pelo colendo Supremo Tribunal Federal. Destaca-se, outrossim, o ponto a que já chegou a matéria: impetrou-se mandado de segurança (n. 16.180) contra decisão de Ministro deste Superior que não conheceu de reclamação oriunda do
} 
"não parece crível poder-se alargar a competência do Superior Tribunal de Justiça em sede de embargos de declaração em recurso extraordinário, que não abarcou a questão, tampouco que esse pronunciamento tenha força vinculante igualando-a às decisões proferidas em ações diretas de inconstitucionalidade e às súmulas vinculantes".

Em que pesem as críticas levantadas, é preciso dizer que, a partir da vigência da Lei Federal 12.153, de 22 de dezembro de 2009, com vacatio de seis meses, ou seja, a partir de 22 de junho de 2010, parte delas perdeu o sentido e o fundamento. Malgrado seja mais fácil uniformizar o entendimento dos Juizados Federais, já que vinculados a uma mesma hierarquia jurisdicional e administrativa, bem ou mal essa lei procura estabelecer um procedimento para que, também no seio dos Juizados dos Estados, a interpretação da lei federal seja uniforme.

Nesse intuito, a chamada Lei dos Juizados da Fazenda Pública prevê, expressamente, em seus artigos $18, \S 3 .^{\circ}$, e 19, caput, a possibilidade de julgamento pelo Superior Tribunal de Justiça dos pedidos de "uniformização de interpretação de lei" quando: (i) as Turmas Recursais de diferentes Estados "derem a lei federal interpretações divergentes ou quando a decisão proferida estiver em contrariedade com súmula do Superior Tribunal de Justiça"; (ii) quando a decisão das Turmas de Uniformização (formadas pela união das Turmas Recursais de determinado Estado ou do Distrito Federal que estiverem em divergência) contrariar súmula do Superior Tribunal de Justiça ${ }^{298}$.

Juizado Especial Estadual por intempestividade. Veja-se, a Corte Especial do Superior Tribunal de Justiça, órgão responsável para o julgamento de ações e recursos com os assuntos da maior relevância para o Estado Brasileiro e com repercussão para todos os demais órgãos jurisdicionais e até administrativos, integrada pelos quinze (15) Ministros mais antigos, teve que se debruçar sobre a contagem de prazo para o ajuizamento de reclamação originada em causa de menor complexidade. Com isso, além da avalanche de processos que já estrangulam a pauta das Seções deste Tribunal, a Corte Especial, da mesma forma, se deparará com essa situação. Mas não é só: sob o mesmo argumento de suposta segurança jurídica, da devida prestação jurisdicional e de um controle dos entendimentos prolatados pelas Turmas Recursais, admitir-se-á recurso ou propositura de ação perante o c. Supremo Tribunal Federal, contra o julgamento prolatado pela Corte Especial do Superior Tribunal de Justiça. Atentem-se Senhores Ministros e Senhoras Ministras: de uma causa de menor complexidade, em que parte do direito material é renunciado exclusivamente em razão da via eleita e alguns requisitos e dogmas do processo civil são suprimidos, está-se admitindo o acesso a um Tribunal Superior, no qual os julgadores devem, sob pena de nulidade, proferir decisão com relatório, fundamentação e dispositivo. Enfim, enquanto todos os esforços estão voltados para uma otimização da prestação jurisdicional, está-se criando mais um entrave para a efetividade dos julgados" (Rcl. 6721/MT, 2 . $^{\mathrm{a}} \mathrm{S}$., rel. MiN. MASSAMI UYEDA, rel. p/ acórdão MIN. NANCY ANDRIGHI, j. 23/11/2011, DJe 09/11/2012).

${ }^{298}$ Convém mencionar que, para evitar regulamentações diversas no âmbito dos Tribunais de Justiça, o Conselho Nacional de Justiça - CNJ editou o Provimento 7/2010, estabelecendo o procedimento do incidente de uniformização de interpretação de lei previsto nos artigos 18 e 19 da Lei Federal 12.153/2009. Convém trazer, também, notícia de que já estão sendo julgados os incidentes de uniformização de jurisprudência baseados nessas hipóteses legais. V., por exemplo: AgRg na Pet 10116/SC, 1. a S., rel. MIN. HERMAN BENJAMIN, j. 26/11/2014, DJe 05/12/2014, no qual se reafirma o entendimento segundo o qual "os recursos 
De saída, não se pode admitir a interpretação restritiva que o STJ tem dado aos dispositivos legais, aplicando-os apenas aos Juizados Estaduais da FazendaPública e excluindo sua aplicação aos demais ${ }^{299}$. Conforme ensina JORGE TOSTA, o pedido de uniformização de interpretação de lei é cabível quando houver divergência sobre questões de direito material "entre decisões proferidas por Turmas Recursais de qualquer Juizado integrante do sistema dos Estados e do Distrito Federal, o qual é formado, segundo disposto no art. 1. ${ }^{\circ}$, parágrafo único, pelos Juizados Especiais Cíveis, Juizados Especiais Criminais e Juizados Especiais da Fazenda Pública"300.

Portanto, a partir de junho de 2010, há previsão expressa de cabimento de uma medida uniformizadora perante o Superior Tribunal de Justiça para preservação de sua Súmula de Jurisprudência, nos casos de contrariedade, por parte dos órgãos colegiados dos Juizados Especiais Estaduais (da Fazenda ou não), a seus verbetes sumulares.

de uniformização jurisprudencial são destinados a dirimir teses jurídicas conflitantes, e não exame específico de elementos fáticos do caso concreto para aplicar o melhor direito à espécie", ou seja, ratificam tratar-se de caso de controle de precedentes do STJ, perante os Juizados Especiais, papel que, para alguns, deveria ser da reclamação constitucional; AgRg na Pet 10598/AC, 1. ${ }^{a}$ S., rel. MIN. BENEDITO GONÇALVES, j. 22/10/2014, DJe 29/10/2014, no qual se confirma a regra constante do artigo 12, § $4 .^{\circ}$, do Provimento supracitado, segundo a qual "para a comprovação do Incidente de Uniformização de Jurisprudência faz-se necessária a realização da prova da divergência "mediante certidão, cópia do julgado ou pela citação do repositório de jurisprudência, oficial ou credenciado, inclusive em mídia eletrônica, em que tiver sido publicada a decisão divergente, ou seja, pela reprodução de julgado disponível na internet, com indicação da respectiva fonte, mencionando, em qualquer caso, as circunstâncias que identifiquem ou assemelhem os casos confrontados". 299"RROCESSUAL CIVIL. PEDIDO DE RECONSIDERAÇÃO NO AGRAVO REGIMENTAL NA RECLAMAÇÃO. RECEBIMENTO COMO AGRAVO REGIMENTAL. PRINCÍPIO DA FUNGIBILIDADE. DECISÃO RECORRIDA PROFERIDA POR TURMA RECURSAL DO JUIZADO ESPECIAL DA FAZENDA PÚBLICA. REGIME PRÓPRIO DE SOLUÇÃO DE DIVERGÊNCIA (ARTS. 18 E 19 DA LEI 12.153/2009). DESCABIMENTO DA RECLAMAÇÃO PREVISTA NA RESOLUÇÃO 12/2009 DO STJ. SUCEDÂNEO RECURSAL. IMPOSSIBILIDADE. PRINCÍPIO DA FUNGIBILIDẢDE. INAPLICABILIDADE. 1. Tendo em vista o escopo de reforma do julgado, aplica-se o princípio da fungibilidade recursal, para conhecer da manifestação da parte como Agravo Regimental. 2. A Primeira Seção desta Corte firmou o entendimento de que: i) a reclamação disciplinada pela Resolução 12/2009 não é cabível contra decisões proferidas no âmbito do Juizado Estadual da Fazenda Pública, tendo em vista que o art. 18 da Lei n. 12.153/2009 previu o cabimento de pedido de uniformização de interpretação de lei em relação às questões de direito material; e ii) não há falar na possibilidade de receber a insurgência reclamatória como sucedâneo recursal, tampouco como Incidente de Uniformização de Interpretação de Lei, haja vista o rito específico desse último e o fato de não haver dúvida objetiva sobre o instrumento de impugnação cabível na espécie, configurando-se erro grosseiro o manejo da reclamatória. Precedentes: AgRg na Rcl. 12.496/SP, Rel. Min. Assusete Magalhães, Primeira Seção, DJe 04/06/2014; AgRg na Rcl. 15.676/AP, Rel. Min. Benedito Gonçalves, Primeira Seção, AgRg na Rcl. 15.700/AP, Rel. Min. Arnaldo Esteve Lima, Primeira Seção, DJe 25/04/2014; AgRg na Rcl. 12.756/SP, Rel. Min. Herman Benjamin, Primeira Seção, DJe 17/06/2014. 3. Agravo regimental não provido" (RCD no AgRg na Rcl. 9614/SP, 1. ${ }^{\text {a S., }}$ rel. Min. BENEDITO GonÇALVES, j. 27/08/2014, DJe 1. ${ }^{\circ} / 9 / 2014$ ).

${ }^{300}$ Juizados Especiais da Fazenda Pública, p. 143-144. No mesmo sentido, posicionou-se o MiN. TeORI ZAVASCKI, no STF, ao votarna Rcl. 4335/AC, rel. Min. GILMAR MENDES, j. 20/03/2014, DJe 22/10/2014, e antes já mencionada. 
É verdade que a previsão legal, em si, não significa que as Turmas de Uniformização foram, de fato, criadas nos Estados e no Distrito Federal; tampouco que seu funcionamento esteja de acordo com a previsão legal, ou seja, que sejam constituídas por todas as Turmas Recursais “em conflito” (art. 18, $\left.§ 1^{\circ}\right)^{301}$. Mas que há base legal para que o Superior Tribunal de Justiça proceda à uniformização de jurisprudência no âmbito dos Juizados, isso é inquestionável. O nomen iuris da medida é o que menos importa. Chamá-la de "pedido de uniformização" ou porventura de "reclamação" nada interfere no fato de que sua função será a revisão das decisões que contrariarem súmula do STJ.

O problema permanece, todavia, quanto ao espectro de aplicação da solução dada pelo Supremo, regulada pela Resolução 12/2009 do STJ $^{302}$, em especial diante de seu artigo $1 .^{\circ}$, que define quais serão os paradigmas possíveis: jurisprudência, súmulas ou orientações decorrentes do julgamento de recursos especiais repetitivos.

Note-se que a hipótese regimental é mais ampla que aquela prevista na Lei dos Juizados Especiais da Fazenda Pública, que apenas a prevê em caso de contrariedade à "súmula do Superior Tribunal de Justiça" (arts. 18, §3. ${ }^{\circ}$, e 19), mas é semelhante à prevista na Lei dos Juizados Federais, que se aplica a contrariedades à "súmula ou jurisprudência dominante no Superior Tribunal de Justiça - STJ” (art. 14, §4. $\left.{ }^{\circ}\right)$ - destacamos.

Nada obstante, o STJ tem entendido que é necessário interpretar restritivamente a expressão "jurisprudência", contida no citado artigo 1. ' da Resolução 12/2009, para que abarque apenas súmula ou precedente proferido em sede de recurso especial repetitivo, criando uma hipótese intermediária, ou seja, mais ampla que a da própria Lei dos Juizados da Fazenda (aplicável aos Juizados Estaduais) mas mais restrita que a da Lei dos Juizados Federais e, de certo modo, que a ratio decidendi do acórdão do Supremo Tribunal Federal, que não fazia qualquer restrição ${ }^{303}$. Além disso, quando o paradigma for uma súmula,

\footnotetext{
${ }^{301}$ No Estado de São Paulo, por exemplo, são mais de cem Turmas Recursais. Se houver divergência entre metade delas, será inviável a união de todos os seus membros, pois isso implicaria a criação de um órgão maior que o próprio plenário do Tribunal de Justiça, que, afinal, é representado pelo seu Órgão Especial, composto de apenas 25 desembargadores.

302 "Art. $1^{\circ}$. As reclamações destinadas a dirimir divergência entre acórdão prolatado por turma recursal estadual e a jurisprudência do Superior Tribunal de Justiça, suas súmulas ou orientações decorrentes do julgamento de recursos especiais processados na forma do art. 543-C do Código de Processo Civil serão oferecidas no prazo de quinze dias, contados da ciência, pela parte, da decisão impugnada, independentemente de preparo."

${ }^{303}$ Veja-se, a propósito, a seguinte ementa: "DIREITO CIVIL E PROCESSUAL CIVIL. RECLAMAÇÃO. TARIFAS BANCÁRIAS. LEGALIDADE. TARIFA DE CADASTRO. 1.- A Reclamação de que trata a Resolução/STJ n ${ }^{\circ}$ 12/2009 não pode ser proposta para discutir questões de direito processual (AgRg no MS
} 
ainda se faz necessário colacionar aos autos os acórdãos que originaram o enunciado, demonstrando a similitude fática entre as causas confrontadas ${ }^{304}$.

Pelo exposto, não vemos necessidade em alterar a Lei Federal 9.099/1995, e entendemos que o Projeto de Lei 4.723/2004, que tinha esse objetivo, é natimorto, salvo se vier para legalizar o entendimento reiterado do Superior Tribunal de Justiça que aceita as reclamações também quando a decisão reclamada contrariar "jurisprudência dominante" do tribunal.

Lembre-se, ademais, que a decisão do STF foi dada sob a seguinte condição: até a criação da turma de uniformização dos juizados especiais estaduais. Mas também fez menção à existência de um recurso cabível contra a eventual decisão da Turma de Uniformização que fosse contrária à jurisprudência do STJ. Com isso, não é abuso dizer que o Supremo acabou por entender constitucional a previsão de recurso para o STJ contra a decisão a Turma de Uniformização dos Juizados Federais ${ }^{305}$.

Assim, considerado o teor limitativo do artigo 18 da lei, bem como que acórdãos decididos em sede de recursos especiais repetitivos estão abarcados no conceito de "jurisprudência dominante", forçoso concluir que, com relação aos acórdãos que a contrariem, o cabimento da reclamação ainda se fundamentará no acórdão do Supremo Tribunal Federal, pois aquela condição nele estabelecida ainda não se verificou de modo a atingir todas as formas de desrespeito à interpretação dada à lei federal pelo STJ (como ocorre na previsão da Lei dos Juizados Federais, mencionada e elogiada pelo acórdão do STF).

18.665/MT, Rel. Ministro CASTRO MEIRA, CORTE ESPECIAL, DJe 12/11/2012). 2.- A expressão 'jurisprudência do Superior Tribunal de Justiça' constante no art. $1^{\circ}$ da Resolução/STJ no 12/2009, deve ser interpretada em sentido estrito, admitindo-se como tal, apenas o entendimento absolutamente consolidado no âmbito desta Egrégia Corte, no que se refere à aplicação da lei, ou seja, apenas quando este Tribunal já tenha editado Súmula a respeito da matéria de direito material controvertida ou proferido julgamento de Recurso Especial representativo da controvérsia sobre a questão, pelo rito dos Recursos Especiais Repetitivos (CPC, art. 543-C, com a redação da Lei 11.672, de 8.5.2008). (AgRg na Rcl. 4312/RJ, Rel. Ministro PAULO DE TARSO SANSEVERINO, SEGUNDA SEÇÃO, DJe 25/10/2010). 3.- A 2. ${ }^{a}$ Seção, no julgamento do REsp 1.251.331/RS, Rel. Ministra MARIA ISABEL GALLOTTI, SEGUNDA SEÇÃO, DJe 24/10/2013, lavrado sob o regime do artigo 543-C do Código de Processo Civil, afirmou ser 'válida a Tarifa de Cadastro expressamente tipificada em ato normativo padronizador da autoridade monetária, a qual somente pode ser cobrada no início do relacionamento entre o consumidor e a instituição financeira.' 4.Reclamação parcialmente provida" (STJ, 2. a S., Rcl. 16.644, rel. MIN. SIDNEI BENETTI, v. u., j. 28/05/2014, DJe 02/06/2014) - destacou-se.

${ }^{304}$ LUCON, ob. cit., p. 302.

${ }^{305}$ No mesmo sentido, parece ser a posição de LUCON, ob. cit., p. 300; e CAMBI E MINGATI, Nova hipótese de cabimento da reclamação, protagonismo judiciário e segurança jurídica, p. 295. 
Portanto, a criação em si das Turmas de Uniformização não significa que deixa de haver contrariedade à Jurisprudência do STJ (só súmula), ou seja, que o problema diagnosticado pelo julgado do Supremo Tribunal Federal está solucionado. Isso porque as decisões tomadas por esses órgãos uniformizadores ainda poderiam contrariar precedente do Superior Tribunal de Justiça, quando, então, restaria o cabimento da reclamatória com base no artigo 105, I, $f$, da Constituição Federal.

Todavia, tanto para os casos já regulados em lei como para os que ainda se pode dizer estejam vinculados ao acórdão do STF, resta discutir, primeiro, a constitucionalidade dos primeiros, e a sobrevivência destes. Em suma, é saber se a decisão do STF simplesmente interpretou de maneira ampliativa o cabimento da reclamação prevista no artigo 105, I, $f$, da CF/1988 ou se está errada porque cria nova espécie de recurso especial não prevista na Constituição. E, diga-se de passagem, interpretou-a de maneira mais ampla do que interpreta o cabimento da reclamação de sua própria competência (art. 102, I, $l$, da CF/1988), pois entende cabível o remédio apenas contra acórdãos dotados de eficácia erga omnes e efeito vinculante.

A questão está em saber se os precedentes do Superior Tribunal de Justiça se aplicam ao microssistema dos Juizados Especiais ou não. Em outras palavras, os juízes e colégios recursais dos Juizados devem seguir as súmulas do STJ? Há lei que, de alguma forma, vincule as decisões dos Juizados à jurisprudência sumulada ou dominante do STJ?

Já se disse acima que a eficácia expansiva das decisões do STJ e do STF é criação legislativa voltada à otimização do trabalho judiciário, à uniformização dos entendimentos, à preservação da segurança jurídica e da isonomia. A força da jurisprudência dos tribunais superiores vem prevista, substancialmente, no Código de Processo Civil. Exemplo disso são o artigo 518, $\S 1 .^{\circ}$, que consagrou a chamada súmula impeditiva de recurso, e o artigo $544, \S \S 3 .^{\circ}$ e4. ${ }^{\circ}$, que atribuíram competência ao relator de agravo de instrumento em recurso especial e em recurso extraordinário para, desde logo, invocando jurisprudência ou súmula do STJ ou STF, conhecer do agravo e prover o próprio recurso cuja admissibilidade fora negada.

Sabe-se, por seu turno, que o microssistema dos Juizados Especiais não obedece a regras do processo civil comum, pois é regido por regras e princípios próprios, sendo atribuída aos Estados e ao Distrito Federal competência concorrente para legislar sobre 
“criação, funcionamento e processo do juizado de pequenas causas"(art. 24, X, da $\mathrm{CF} / 1988)$.

Como se nota, a Constituição, muito embora estabeleça certa autonomia ao microssistema dos Juizados (art. 98, I, da CF/1988), não vai além das regras processuais. Com efeito, não parece fazer sentido que o constituinte admita a possibilidade de o direito material ser definido de forma diversa de acordo com a complexidade da causa ${ }^{306}$. Para ficarmos no exemplo que motivou a interpretação extensiva do artigo 105, I, $f$, da CF/1988, pelo $\mathrm{STF}^{307}$, parece contrariar a isonomia que o consumidor que ajuíze uma demanda perante o Juizado Especial veja reconhecido o direito a não pagar pela assinatura básica de telefonia, enquanto outro consumidor, que optou por ajuizar a demanda perante a Justiça Comum não receba a tutela jurisdicional pleiteada. Torna-se mais estranha ainda tal situação se levarmos em conta, na linha do acórdão do Supremo, que a função constitucional do Superior Tribunal de Justiça é exatamente a de uniformizar a interpretação da lei federal.

Destarte, entre entender que a reclamação ao Superior Tribunal de Justiça implica criação de nova hipótese de recurso especial que contraria a Constituição Federal - e, assim, tolerar a aplicação desuniforme do direito federal - e compreender as inovações legislativas como alargamento - ou regulamentação, por que não? - do campo de atuação da reclamação constitucional do artigo 105, I, $f$, da CF/1988 parece mais razoável a segunda alternativa.

\footnotetext{
${ }^{306}$ Embora não seja objeto desse estudo, não é razoável que haja divergência com relação a questões processuais no âmbito da Federação, já as leis federais que tratam do direito processual deveriam ser interpretadas de forma uniforme e coerente. É preciso refletir sobre um modelo que permite, por exemplo, que um determinado tribunal admita a complementação de preparo recursal enquanto outro, de outra Justiça, não admita. Em boa hora, portanto, a proposta feita no artigo 1004, §2. ${ }^{\circ}$, do Projeto de Código de Processo Civil, ao estabelecer que "a insuficiência no valor do preparo, inclusive porte de remessa e retorno, implicará deserção, se o recorrente, intimado na pessoa de seu advogado, não vier a supri-lo no prazo de cinco dias". Mas a questão da divergência de interpretação da lei federal em matéria processual permanece. Pode-se até tolerar que certo sistema processual trate de forma diferente, por exemplo, a questão do preparo recursal. $\mathrm{O}$ que não se pode aceitar é que, uma vez tratada de forma idêntica, ou seja, exigindo o preparo sob pena de deserção, cada tribunal ou Justiça ou microssistema aplique de uma forma a lei. Isso tudo, sem adentrar da imbricada diferenciação entre matéria processual e procedimental. Todavia, por enquanto, as restrições estão sendo aplicadas; no AgRg na Rcl. 20126/SC, em que a Agravante sustentava o cabimento do recurso, nos termos do art. 258 do RISTJ, bem como a viabilidade da reclamação apresentada, repisando as alegações lançadas na inicial, no sentido de que a decisão reclamada diverge do entendimento firmado pelo Superior Tribunal de Justiça, no que concerne ao preparo recursal e à possibilidade de sua complementação, sendo indevida a multa por litigância de má-fé aplicada na Justiça Especializada, a reclamação foi indeferida de plano por tratar de matéria processual (STJ, 1. ${ }^{\text {a }}$ S., rel. MiN. REGINA HELENA CosTA, v. u., j. 12/11/2014, DJe 20/11/2014).

${ }^{307}$ EDcl. no RE 571.572/BA.
} 
Isto, claro, com as restrições impostas pela legislação e pela jurisprudência do STJ, o qual só a admite quando já tenha “editado Súmula a respeito da matéria de direito material controvertida ou proferido julgamento de Recurso Especial representativo da controvérsia sobre a questão, pelo rito dos Recursos Especiais Repetitivos”. E, nada obstante os artigos 18, §3. ${ }^{\circ}$, e 19, caput, da Lei Federal 12.153/2009 se restrinjam apenas aos casos de súmula do STJ, convém compreender o entendimento jurisprudencial e regimental do STJ como válido, baseado na premissa de se tratar de interpretação extensiva da hipótese constitucional.

Adira-se que a não previsão de cabimento de recurso especial de decisões tomadas no âmbito dos Juizados Especiais visa, sobretudo, a atender o princípio da celeridade (rectius: duração razoável do processo). Não se pode criar nos Juizados um locus de divergência jurisprudencial e desigualdade a partir da complexidade das causas, pois a circunstância de uma causa envolver valores menores, por exemplo, não é discrímen legítimo para diferenciar a forma de incidência do direito material envolvido.

A tese de que se trata de hipótese nova de recurso especial, que só poderia ser criada por emenda à Constituição, também não se sustenta, pois, como visto, se a reclamação constitucional existe para controlar a eficácia das decisões do STJ e do STF, a compreensão de o que seja "autoridade de suas decisões", ou melhor, "decisões" pode ser dada tanto pelo próprio tribunal como vir regulamentada por lei. Ademais, sendo ação, está correta sua disciplina por lei federal ${ }^{308}$, nada obstante o STF tenha entendido se tratar de encarnação do direito de petição, motivo pelo qual pode ser disciplinada até mesmo pelos regimentos internos dos Tribunais ${ }^{309}$.

É imprescindível, entretanto, que o Superior Tribunal de Justiça, diante da expressa regulamentação dada pela Lei dos Juizados da Fazenda Pública, revogue a Resolução 12/2009 e passe a se valer das regras legais respectivas. Valem aqui, também, as

\footnotetext{
${ }^{308}$ Assim, Cláudia HelENA POGGIO CoRTEZ: "Sendo a reclamação constitucional considerada uma ação, a conclusão óbvia é que somente pode ser disciplinada por lei federal, já que se trata de matéria de processo, cuja competência legislativa é privativa da União (art. 22, I, da CF/88)" (O cabimento da reclamação constitucional no âmbito dos Juizados Especiais Estaduais, RePro 188/253).

309، AÇÃO DIRETA DE INCONSTITUCIONALIDADE. ARTIGO 108, INCISO VII, ALÍNEA I DA CONSTITUIÇÃO DO ESTADO DO CEARÁ E ART. 21, INCISO VI, LETRA $J$ DO REGIMENTO DO TRIBUNAL DE JUSTIÇA LOCAL. PREVISÃO, NO ÂMBITO ESTADUAL, DO INSTITUTO DA RECLAMAÇÃO. INSTITUTO DE NATUREZA PROCESSUAL CONSTITUCIONAL, SITUADO NO ÂMBITO DO DIREITO DE PETIÇÃO PREVISTO NO ARTIGO 5. ${ }^{\circ}$, INCISO XXXIV, ALÍNEA A DA CONSTITUIÇÃO FEDERAL. INEXISTÊNCIA DE OFENSA AO ART. 22, INCISO I DA CARTA” (ADI 2.212-1/CE, rel. MIN. ELLEN GRACIE, v.m, j. 02/10/2003, DJ 20/11/2003).
} 
ponderações feitas com relação à ampliação do uso da reclamação para fins de salvaguardar e eficácia vinculante de decisões do Supremo, em especial o risco de sobrecarregar ainda mais esses tribunais com processos individuais, quando o movimento todo de reformas caminha para a molecularização das demandas e o julgamento de casosmodelo.

Nesse ponto, discordamos de PAULO LUCON, para quem a hipótese aqui tratada é diferente daquelas em que o Supremo Tribunal Federal aceita a reclamação para controlar a obediência ao quanto decidido em sede de controle de constitucionalidade ${ }^{310}$. Tanto lá quanto cá, todavia, a reclamação é utilizada na garantia da ratio decidendi das decisões do tribunal, ou seja, como salvaguarda do respeito à tese fixada.

Do mesmo modo, não parece correta a afirmação de que o STJ, nesses casos de reclamação contra decisão emanada de Juizados Especiais, esteja aplicando a teoria dos motivos determinantes, ou seja, esteja confrontando os fundamentos das decisões reclamadas com os da sua decisão paradigma. Da leitura de acórdãos do STJ e do STF, não vislumbramos essa diferença apontada pelo autor entre as hipóteses. Ambos os tribunais buscam nas razões das decisões paradigmas os fundamentos para analisarem as reclamações propostas, não se fixando apenas no preceito, ou seja, no dispositivo; essa é uma preocupação especial do STF, aliás, nos casos em que admite a reclamação para controlar precedentes. Portanto, trata-se de hipóteses semelhantes de utilização da reclamação para fazer valer a força vinculante das teses fixadas por essas Altas Cortes.

Ainda com relação ao tema aqui tratado, há uma decisão recente que merece comentário. É que foi concedida liminar em reclamação ${ }^{311}$ para que fosse cumprida decisão de relator de recurso especial repetitivo ${ }^{312}$, que determinara a suspensão dos recursos nos quais a controvérsia esteja estabelecida, deixando expresso que a comunicação deveria ser feita também aos Juizados Especiais, “considerando o volume de demandas que versam sobre a matéria discutida nestes autos e, inclusive, o ajuizamento de

\footnotetext{
${ }^{310}$ Ob. cit., p. 304 e 305.

311 EDcl. na Recl.12.273/ RJ, rel. MiN. HERMAN BENJAMIN, decisão de 05/06/2014, DJE de 24/06/2014. Trata-se de hipótese já aventada por MARINONI ( $O$ STJ enquanto Corte de precedentes, p. 245).

312 “ADMINISTRATIVO. RECURSO ESPECIAL. AÇÃO DE REPETIÇÃO DE INDÉBITO. SERVIÇO DE ESGOTAMENTO SANITÁRIO. PRESTAÇÃO DE SERVIÇOS DE COLETA E TRANSPORTE DOS DEJETOS. INEXISTÊNCIA DE REDE DE TRATAMENTO. TARIFA. LEGITIMIDADE DA COBRANÇA” (REsp 1.339.313/RJ, 1. ${ }^{a}$ S., rel. MIN. BENEDITO GONÇALVES, j. 12/06/2013).
} 
reclamações nesta Corte"313. É dizer, a reclamação visava a garantir a autoridade da decisão do relator do recurso especial repetitivo que apenas determinava a suspensão dos recursos veiculadores da mesma matéria, ou seja, não se tratava da decisão tomada sobre o mérito do especial, esta sim aplicável ao microssistema dos Juizados, em razão da previsão regimental e legal (Lei dos JEFP).

Entendemos que não se trata de caso de aplicação da Resolução 12/09, mas de hipótese ordinária do artigo 105 , I, $f$, da $\mathrm{CF} / 1988$, pois além de ser matéria meramente processual $^{314}$, não houve contrariedade à jurisprudência, súmula ou acórdão julgado sob o rito dos recursos repetitivos. Em outras palavras, era aplicação pura e simples do texto constitucional, que prevê a reclamação para garantia da autoridade do julgado do tribunal, consubstanciado, na espécie, na decisão do relator do recurso especial, que determinou certou ou errado, pouco importa - a suspensão dos recursos nos quais a controvérsia esteja estabelecida, inclusive os em trâmite perante os Juizados Especiais.

A decisão paradigma, ao determinar a suspensão dos recursos que vertessem a matéria veiculada no referido recurso especial pode até ter aplicado a sistemática dos recursos repetitivos para abarcar também reclamações, mas nem de longe se assemelha à espécie aqui tratada. Pode até partir da premissa de que a decisão a ser tomada no recurso especial repetitivo valerá, também, para os Juizados, mas a sua autoridade e a sua execução pelos órgãos jurisdicionais destinatários é garantida pela reclamação prevista na Lei 8.038/1990, não pela hipótese da Resolução 12/2009.

\footnotetext{
${ }^{313}$ Vale ressaltar que o artigo $2^{\circ}$, I, da Resolução 12/09 prevê expressamente a possibilidade dessa suspensão nos autos das reclamações ali disciplinadas, a ser deferida em liminar, quando do recebimento da medida.

${ }^{314}$ A jurisprudência do STJ mantém o entendimento de somente ser cabível a reclamação da Resolução 12/09 contra decisões proferidas nos Juizados que contrariem a ratio decidendi do julgado de mérito, já que a lei expressamente assim prevê, excluindo questões processuais. Aliás, com relação ao procedimento estabelecido na Resolução 12/09, é preciso assentar que, além de não ser cabível a reclamação quando o precedente tido por violado tratar de matéria "eminentemente processual", a decisão do relator que não a admitir será irrecorrível. Assim, recente julgado da 1. ${ }^{a}$ Seção do STJ: "PROCESSUAL CIVIL. AGRAVO REGIMENTAL NA RECLAMAÇÃO. RESOLUÇÃO STJ12/2009. RECLAMAÇÃO INADMITIDA POR DISCUTIR QUESTÃO PROCESSUAL.DECISÃO DO RELATOR IRRECORRÍVEL.1. Agravo regimental contra decisão do relator que julgoumanifestamente incabível a reclamação, sob o fundamento de que aResolução STJ 12/2009 não autoriza rever decisão de Turma Recursalestadual acerca de questão eminentemente processual, no caso, relativa à possibilidade, ou não, de complementação do preparo dorecurso inominado.2. No âmbito da Resolução STJ 12/2009 (art. 6. ${ }^{\circ}$ ), as decisõesproferidas pelo relator são irrecorríveis, o que revela o nãocabimento do presente agravo regimental. Precedentes: AgRg na Rcl. 18.281/BA, Rel. Ministro Sérgio Kukina, Primeira Seção, DJe01/09/2014; AgRg na Rcl. 12.496/SP, rel. Ministra AssuseteMagalhães,Primeira Seção, DJe 04/06/2014; AgRg na Rcl. 15.689/AP, Rel.MinistroAri Pargendler, Primeira Seção, DJe 05/06/2014; AgRg nos EDcl noRCDna Rcl. 12.205/SP, Rel. Ministro Herman Benjamin, Primeira Seção,DJe 17/06/2014. 3. Agravo regimental não conhecido" (AgRg na Rcl. 20114/SC, 1. ${ }^{a}$ S., rel. MiN. BENEDITO GonÇALVES, v.u., j. 22/10/2014, DJe 29/10/14). No mesmo sentido: MS 18.514/DF, rel. MiN. SIDNEI BENETTI, Corte Especial, j. 05/06/2013, DJe 25/06/2013.
} 
Por essa razão, está errada a decisão do relator da reclamação, que a extinguiu por ausência de comprovação da tempestividade da medida com a juntada da cópia da publicação do decisum reclamado ${ }^{315}$. Não poderia, portanto, a nosso ver, ser aplicada a restrição estabelecida pela Resolução 12/2009, quando nem a Constituição nem a Lei 8.038/1990 estabelecem qualquer restrição nesse sentido. Ou seja, não era caso de extinção da reclamação sem julgamento do mérito.

Aqui, vale retornar à ponderação sobre a necessidade de analisar os destinatários da eficácia das decisões cuja autoridade será controlada via reclamação. Toda a discussão sobre a hipótese aqui debatida - descumprimento de precedentes do STJ por Turmas Recursais de Juizados Especiais Estaduais - vem da constatação inicial de que, antes do acórdão do STF, não se cogitava de vincular as decisões dos Juizados à jurisprudência do Superior Tribunal de Justiça.

Vale dizer, os precedentes do STJ poderiam nem sequer ser usados como referência pelos Juizados Especiais; além de aceitar com tranquilidade a tese de que os Juizados formavam um microssistema à parte, autônomo também no tocante à interpretação a ser dada a lei federal (já que sempre coube recurso extraordinário de suas "últimas decisões" art.103, III, da CF/1988), não havia a preocupação com a segurança jurídica e com a unicidade do direito federal exposta no voto da MinISTRA ELLEN GRACIE.

Por outro lado, nunca se discutiu que, para garantir a autoridade de todas as decisões do Superior Tribunal de Justiça, sempre foi aceita a reclamação constitucional, pouco importando o destinatário da decisão descumprida, ou seja, o reclamado. Basta cogitar de uma decisão que julgue conflito de competência entre um Tribunal de Justiça e um Tribunal Regional do Trabalho (art. 105, I, $d$, da CF/1988). Nunca se questionou que a solução adotada pelo STJ deveria ser cumprida pelo órgão da Justiça do Trabalho. Em outros termos, não se pode confundir a eficácia dos precedentes do STJ com a eficácia de suas decisões.

\footnotetext{
315 “...] a jurisprudência do STJ é no sentido de que incumbe à parte comprovar, no ajuizamento da Reclamação prevista na Resolução STJ 12/2009, a sua tempestividade, o que é feito mediante juntada de cópia da publicação do decisum recorrido. No caso, verifico que a Reclamante não comprovou a data da publicação do acórdão proferido nos aclaratórios julgados pela Terceira Turma Recursal - consta apenas a cópia da certidão de julgamento, realizado em 19.2.2013 (fl. 299, e-STJ).Dessa forma, não há elementos que viabilizem aferir a tempestividade no ajuizamento desta Reclamação, em 16.4.2013. Por tudo isso, extingo o feito sem resolução do mérito, nos termos do art. 34, XVIII, do RI/STJ" (decisão monocrática do relator, 18/11/2014, DJe 05/12/2014).
} 
Em suma, a hipótese criada pela Resolução do STJ 12/2009 vela pelo respeito à interpretação que esse tribunal dá à lei federal e não tem nada que ver com a obrigatória observância de suas decisões, que devem ser cumpridas por todos a quem endereçadas.

Ainda gravitando em torno do tema ora em análise, vale mencionar outro acórdão recente que subverte por completo a disciplina da reclamação constitucional, pois, além de, analogicamente, a ter recebido como "representativa de controvérsia", como se recurso especial repetitivo fosse, julgou-a procedente para cassar acórdão de Turma Recursal de Juizado Especial Estadual reputado teratológico; em outras palavras, sem que tenha havido “divergência entre acórdão prolatado por turma recursal estadual e a jurisprudência do Superior Tribunal de Justiça, suas súmulas ou orientações decorrentes do julgamento de recursos especiais processados na forma do art. 543-C do Código de Processo Civil” (art. 1. ${ }^{\circ}$ da Res. 12/2009).

O reclamante alegou que o acórdão reclamado manteve a decisão singular que julgou extra petita a demanda ao condená-lo à indenização (por dano social) que nem sequer foi requerida pelo demandante $e^{316}$.

Contudo, não parece possível a aplicação analógica do artigo 543-C do Código de Processo Civil às reclamações, ainda que o STJ as entenda como de natureza recursal. O regime dos recursos repetitivos pressupõe o preenchimento de requisitos que a reclamação não preenche, bastando ver que o cabimento desta é que somente existe se já tiver havido julgamento de recurso especial repetitivo. Em outros termos, a reclamação regulada pela Resolução 12/2009 existe para fazer valer perante os Juizados Especiais Estaduais a tese

\footnotetext{
316،RECLAMAÇÃO. ACÓRDÃO PROFERIDO POR TURMA RECURSAL DOS JUIZADOS ESPECIAIS. RESOLUÇÃO STJ N. 12/2009. QUALIDADE DE REPRESENTATIVA DE CONTROVÉRSIA, POR ANALOGIA. RITO DO ART. 543-C DO CPC. AÇÃO INDIVIDUAL DE INDENIZAÇÃO. DANOS SOCIAIS. AUSÊNCIA DE PEDIDO. CONDENAÇẪO EX OFFICIO. JULGAMENTO EXTRA PETITA. CONDENAÇÃO EM FAVOR DE TERCEIRO ALHEIO À LIDE. LIMITES OBJETIVOS E SUBJETIVOS DA DEMANDA (CPC ARTS. 128 E 460). PRINCÍPIO DA CONGRUÊNCIA. NULIDADE. PROCEDÊNCIA DA RECLAMAÇÃO. 1. Na presente reclamação a decisão impugnada condena, de ofício, Em ação individual, a parte reclamante ao pagamento de danos sociais em favor de terceiro estranho à lide e, nesse aspecto, extrapola os limites objetivos e subjetivos da demanda, na medida em que confere provimento jurisdicional diverso daqueles delineados pela autora da ação na exordial, bem como atinge e beneficia terceiro alheio à relação jurídica processual levada a juízo, configurando hipótese de julgamento extra petita, com violação aos arts. 128 e 460 do CPC. 2. A eg. Segunda Seção, em questão de ordem, deliberou por atribuir à presente reclamação a qualidade de representativa de controvérsia, nos termos do art. 543-C do CPC, por analogia. 3. Para fins de aplicação do art. 543-C do CPC, adota-se a seguinte tese: 'É nula, por configurar julgamento extra petita, a decisão que condena a parte ré, de ofício, em ação individual, ao pagamento de indenização a título de danos sociais em favor de terceiro estranho à lide'. 4. No caso concreto, reclamação julgada procedente" (Rcl. 12062/GO, 2. ${ }^{a}$ S., rel. MIN. RAUl ARAÚJO, j. 12/11/2014, DJe 20/11/2014).
} 
fixada em sede de recursos repetitivos ou em súmula. Se a reclamação for aceita como "representativa de controvérsia" é porque ainda não há tese fixada pelo Superior Tribunal de Justiça e, por isso, não pode ter havido por parte do órgão reclamado qualquer descumprimento que desse ensejo ao cabimento da reclamação.

Não bastasse isso, a espécie julgada trata de matéria eminentemente processual, cuja análise é excluída pela jurisprudência uníssona do STJ em sede da reclamação aqui tratada, em aplicação analógica da restrição constante tanto da Lei dos Juizados Especiais Federais (art. 14) como da Lei dos Juizados Especiais da Fazenda Pública (art. 18). Em suma, por qualquer ângulo, não se encontra amparo legal nem jurídico para a solução alvitrada pelo STJ no caso.

Por isso, temos que é hipótese de cabimento de mandado de segurança para o Tribunal de Justiça, na linha da jurisprudência do próprio Superior Tribunal ${ }^{317}$. Se se ampliar a possibilidade de uso da reclamação para todos os casos de decisão teratológica, estar-se-á olvidando de que seu fundamento é fazer valer a autoridade de uma decisão do tribunal, não da lei. Noutros termos, o mandado de segurança, sim, pode ser usado para fazer valer a autoridade de teses firmadas "com força de lei" pelo STJ e pelo STF, segundo pensamos; não o contrário, ou seja, a reclamação fazer as vezes de mandamus e salvaguardar o respeito à lei.

Vale também ressaltar que a hipótese difere de outros precedentes do STJ nos quais o tribunal, por assim dizer, amaina a interpretação restritiva da expressão "jurisprudência dominante" para aceitar a reclamação quando, embora não haja súmula nem julgamento de recurso especial repetitivo, a decisão reclamada é tida por teratológica por ser contrária à jurisprudência pacífica do tribunal ${ }^{318}$. Trata-se de critério altamente subjetivo e inseguro,

\footnotetext{
${ }^{317}$ No julgamento do RMS 17.524/BA, a rel. MIN. NANCY ANDRIGHI, ao sugerir o mandado de segurança como instrumento de repara lesão ou prevenir ameaça de lesão a direito e admiti-lo contra decisão proferida pelos Juizados Especiais, mas apenas para afastar uma incompetência, ou mesmo decisão teratológica, afirmou que "não está previsto, de maneira expressa na Lei n. 9.099/95, um mecanismo de controle da competência das decisões proferidas pelos Juizados Especiais. É, portanto, necessário estabelecer esse mecanismo por construção jurisprudencial". Assim votou a Ministra, por entender que, do contrário, estar-seia atribuindo ao Juizado Especial "um poder descomunal, fazendo prevalecer suas decisões mesmo quando proferidas por Juiz absolutamente incompetente"(STJ, Corte Especial, sete votos a seis, j. 02/08/2006, DJe 11/09/2006).

318 A propósito, o acórdão citado no corpo do voto do relator do acórdão que vimos de analisar: "RECLAMAÇÃO. RESOLUÇÃO STJ No 12/2009. DIVERGÊNCIA ENTRE ACÓRDÃO DE TURMA RECURSAL ESTADUAL E A JURISPRUDÊNCIA DO STJ. RESPONSABILIDADE CIVIL. ASSALTO NO INTERIOR DE ÔNIBUS COLETIVO. CASO FORTUITO EXTERNO. EXCLUSÃO DA RESPONSABILIDADE DA EMPRESA TRANSPORTADORA. MATÉRIA PACIFICADA NA
} 
mas, pelo menos, se aplicado em casos em que o debate se trava sobre direito material, não viola nenhuma norma legal ou regimental, e vai ao encontro da ratio decidendi do já mencionado voto da MinISTRA ELLEN GRACIE.

Por fim, diante do quadro traçado, parece que a jurisprudência do STJ com relação à hipótese da reclamação contra decisões dos Juizados Especiais, no que tem de ampliativa, é mais um fator a contribuir para a dificuldade de definirmos qual o caminho que está sendo desenhado para o uso do instrumento, se tendente a restrições ou a ampliações. Assim como no Supremo há vozes pela sua ampliação e vozes pela sua restrição ${ }^{319}$, no

SEGUNDA SEÇÃO. 1. A egrégia Segunda Seção desta Corte, no julgamento das Reclamações n. 6.721/MT e n. 3.812/ES, no dia 9 de novembro de 2011, em deliberação quanto à admissibilidade da reclamação disciplinada pela Resolução $\mathrm{n}^{\circ} 12$, firmou posicionamento no sentido de que a expressão "jurisprudência consolidada" deve compreender: (i) precedentes exarados no julgamento de recursos especiais em controvérsias repetitivas (art. 543-C do CPC) ou (ii) enunciados de súmula da jurisprudência desta Corte. $\underline{\mathbf{2}}$. No caso dos autos, contudo, não obstante a matéria não estar disciplinada em enunciado de Súmula deste Tribunal, tampouco submetida ao regime dos recursos repetitivos, evidencia-se hipótese de teratologia a justificar a relativização desses critérios. 3. A jurisprudência consolidada neste Tribunal Superior, há tempos, é no sentido de que o assalto à mão armada dentro de coletivo constitui fortuito a afastar a responsabilidade da empresa transportadora pelo evento danoso daí decorrente para o passageiro. 4. Reclamação procedente" (Rcl. 4.518/RJ, rel. MiN. RICARDO VILlas BôAS CUEVA, 2. ${ }^{a}$ S., j. 29/02/2012, DJe 07/03/2012) - destacamos.

319 O MIN. GILMAR MENDES defende o uso da reclamação como forma de controlar a observância às decisões do STF no controle abstrato de constitucionalidade, com base na teoria da "transcendência dos motivos determinantes", segundo a qual também os motivos que levaram a uma dada conclusão do Tribunal devem vincular os demais órgãos estatais, de modo que, por exemplo, as razões que levaram à declaração de inconstitucionalidade de uma norma de determinado Estado da Federação são suficientes para impedir que outro Estado venha a editar norma de conteúdo semelhante; em caso de vir a ser editada, será cabível reclamação ao STF sob alegação de violação daquela primeira decisão-parâmetro. Por sua vez,o MIN. TEORI ZAVASCKI, no voto que proferiu na Rcl. 4.335/AC, já antes citado, defendeu a restrição da legitimidade ativa para ajuizamento da reclamação, no que foi seguido, expressamente, pelos MinISTROS ROBERTO BARROSO, ROSA WEBER e CELSO DE MELLO. No âmbito do STJ, o entendimento unânime é de que a reclamação não é cabível para controle de teses fixadas pelo Tribunal, mas apenas para garantir o cumprimento da decisão tomada no caso concreto; isso, claro, salvo alguns acórdãos esparsos em matéria afeta ao sistema dos Juizados Especiais Estaduais. A propósito: "AGRAVO EM RECLAMAÇÃO CONSTITUCIONAL. ALEGAÇÃO DE DIVERGÊNCIA ENTRE ACÓRDÃO DE TRIBUNAL ESTADUAL E A JURISPRUDÊNCIA DO STJ CONSOLIDADA EM RECURSO REPETITIVO (ART. 543-C, CPC). NÃO CABIMENTO. 1 . O art. 105 , I, 'f', da $\mathrm{CF} / 88$ prevê o cabimento de reclamação constitucional para 'preservação da competência' do STJ e, ainda, para "garantia da autoridade de suas decisões". Os arts. 13 a 18 da Lei 8.038/90, reproduzindo e regulamentando o texto constitucional, também conferem ao instituto da reclamação essa finalidade exclusiva e taxativa. 2. Segundo a jurisprudência do STJ, para que a reclamação constitucional seja admitida, é imprescindível que se caracterize, de modo objetivo, usurpação de competência deste Tribunal ou ofensa direta à decisão aqui proferida, não sendo possível sua utilização como mero sucedâneo recursal. 3. Os efeitos do julgamento de recurso repetitivo se manifestam apenas na forma do art. 543-C, § 7. ${ }^{\circ}$, do CPC, segundo o qual, com a publicação do acórdão, os recursos sobrestados na origem i) terão seguimento denegado na hipótese de o acórdão recorrido coincidir com a orientação do STJ (inc. I) ou ii) serão novamente examinados pelo tribunal de origem na hipótese de o acórdão recorrido divergir da orientação do STJ (inc. II), fazendo-se, nessa segunda situação, o exame de admissibilidade do recurso especial se mantida a decisão divergente (art. 543-C, § 8. $.^{\circ}, \mathrm{CPC}$ ). 4. Assim, a decisão proferida em recurso repetitivo não possui efeito vinculante e erga omnes. Vale dizer, a consolidação de tese pelo STJ no julgamento de recurso repetitivo não tem o condão de, ipso facto, estender a todos os processos em trâmite no país a eficácia da decisão por meio da qual foi julgado o recurso representativo.5. No âmbito do STJ, a única 
Superior Tribunal de Justiça, portanto, há linhas distintas, caso se trate do âmbito dos Juizados Especiais ou da Justiça Comum.

\subsection{Reclamação no novo Código de Processo Civil: novas hipóteses?}

Como já mostrado, o artigo 985 da última versão publicada do novo Código de Processo Civil, ao generalizar o cabimento da reclamação, prevê sua utilização nas seguintes hipóteses: I - preservar a competência do tribunal; II - garantir a autoridade das decisões do tribunal; III - garantir a observância de decisão do Supremo Tribunal Federal em controle concentrado de constitucionalidade; IV - garantir a observância de súmula vinculante e de precedente proferido em julgamento de casos repetitivos ou em incidente de assunção de competência.

O inciso primeiro traz caso não objeto do presente estudo, mas tanto nesse caso quanto no do inciso II, o texto pretende legalizar uma realidade já legalizada, pois o instituto, nesses moldes, há muito vem previsto em quase todos os Regimentos Internos dos Tribunais do País, e com o beneplácito do STF, que considerou constitucionais tais disposições regimentais ${ }^{320}$. Nesse ponto, então, o novo Código servirá apenas para extirpar qualquer crítica que remanescesse baseada na impossibilidade de normas regimentais criarem uma verdadeira ação.

Mas, além disso, é preciso ponderar que a generalização da reclamação veiculada nos incisos I e II precisa ser analisada em comparação com as hipóteses dos incisos III e IV, pois, caso contrário, seria caso de indagar por que o inciso II já não abarca as hipóteses previstas nos dois últimos incisos? Ou, por acaso, decisão do STF em controle concentrado de constitucionalidade não é “decisão do Tribunal”?

Como a lei não contém palavras inúteis, a única forma de distinguir o inciso II dos seguintes é analisá-los com base na eficácia das decisões judiciais, do ponto de vista de sua função de fixar uma tese jurídica geral e vinculante. Em outras palavras, é viável supor que

possibilidade de cabimento de reclamação com base em acórdão julgado sob o rito dos recursos repetitivos se dá na hipótese, regulamentada pela Resolução STJ 12/2009, de adoção de entendimento divergente, em questões de direito material, por acórdão de Turma Recursal de Juizado Especial Estadual. 6. Em suma, o instituto da reclamação não se destina à reforma de pronunciamento judicial proferido em processo distinto daquele em que prolatada a decisão reclamada. 7. Agravo improvido" (AgRg na Rcl. 16532/RS, 2. ${ }^{\mathrm{a}} \mathrm{S}$., rel. MiN. NANCY ANDRIGHI, j. 28/05/2014, DJe 02/06/2014). No mesmo sentido: AgRg na Rcl. 5065/PB, 1. ${ }^{\text {a }}$ S., rel. Min. HAMILTON CARVALHIDO, j. 23/03/2011, DJe 05/04/2011.

${ }^{320}$ ADI 2.212-1/CE, rel. MiN. ELLEN GRACIE, v. m., j. 02/10/2003, DJ 20/11/2003. 
a previsão do inciso II diz respeito àquelas reclamações voltadas a controlar a executividade da decisão desrespeitada, ou seja, visam a fazer cumprir o comando da decisão, não a tese jurídica que o embasou. Por seu turno, as hipóteses dos incisos III e IV estão, nitidamente, voltadas à garantia da obediência aos precedentes nelas mencionados. Essa constatação, talvez, nos permita divisar alguma distinção entre garantir a "autoridade", hipótese do inciso II, e garantir a "observância", expressão contida nos incisos III e IV.

Noutros termos, quando o legislador fala em "autoridade" quer se referir à eficácia natural de toda decisão judicial, que deve ser cumprida pelos órgãos subalternos da hierarquia judiciária responsáveis pelas providências concretas necessárias à efetividade da tutela jurisdicional concedida. Por outro lado, ao se referir a "observância", a lei esteja tratando de algo além daquela eficácia intrínseca a toda decisão judicial, da eficácia vinculante que deve ser agregada a toda decisão que fixa uma tese jurídica para valer como lei para outros casos; ou seja, da eficácia de precedente que essas decisões passam a ter.

Mas, ultrapassada essa questão inicial, na prática, a única inovação está na possibilidade de garantir a observância de precedente proferido em julgamento de casos repetitivos e em incidente de assunção de competência, hipóteses para as quais o sistema atual não prevê outra medida de controle que não os recursos existentes. A partir da vigência do novo Código, portanto, todo acórdão decidido em sede de recurso especial repetitivo, por exemplo, veiculará uma tese cuja observância nos demais casos poderá ser controlada via reclamação.

Questão interessante é saber se será admitida a reclamação contra decisões de primeira instância que deixem de aplicar a tese fixada em julgamento de caso repetitivo. Vale dizer, se uma decisão interlocutória ou uma sentença contrariar o entendimento fixado no julgamento de um recurso especial sob o regime dos repetitivos, poderá o interessado aportar diretamente no STJ?

Se formos seguir a lógica hoje vigente para as hipóteses de cabimento de reclamação perante o Supremo, a resposta deverá ser positiva, pois vigora a ideia segundo a qual a reclamação existe exatamente para cortar caminho e permitir que o tribunal responsável pela fixação do precedente faça valer sua força vinculante. Assim, ainda que o $\S 4 .^{\circ}$ do citado artigo 985 afirme ser inadmissível a reclamação após o trânsito em julgado da 
decisão, o que forçará o interessado a recorrer, o fato é que será cabível sua utilização em paralelo à do recurso, o que já afirmamos ser um contrassenso sem par. 


\section{CAPÍTULO 4 - ANÁLISE CRÍTICA: (RE)ATOMIZAÇÃO DOS LITÍGIOS}

Não seria preciso dizer da conhecida sobrecarga de trabalho do Poder Judiciário no Brasil. O desenvolvimento da economia em uma sociedade de massas como a brasileira, somado a uma conscientização cada vez maior sobre os direitos, em especial os chamados metaindividuais, se, por um lado, é sinal de salutar incremento da cidadania, por outro tem levado o Estado, destacadamente o Judiciário e o Executivo, a serem chamados a servir mais e melhor a todos.

Consequência natural desse estado de coisas é o descomunal aumento de demandas, quer perante a Administração quer perante o Judiciário (no mais das vezes, envolvendo aquela), estas a abarrotar os escaninhos dos fóruns e tribunais do País ${ }^{321}$. O Supremo Tribunal Federal e o Superior Tribunal de Justiça não saem ilesos dessa avalanche de $\operatorname{processos}^{322}$.

Apontada por muitos como um dos maiores responsáveis pela morosidade da prestação do "serviço judiciário", a técnica processual vem sofrendo grandes manipulações

321 Em agosto de 2014, dos 20.258.821 feitos em andamento em primeiro grau na Justiça Paulista, 11.530.699 são execuções fiscais e 5.599.367 são feitos cíveis. Em 2000, no mesmo mês, tramitavam 6.580.862 execuções fiscais e 2.443.371. Em quatorze anos, o número de processos praticamente dobrou, em que pesem as reforças processuais operadas desde então, o processo digital ainda embrionário e o esforço do CNJ no tocante à produtividade dos magistrados (fonte: sítio eletrônico do Tribunal de Justiça de São Paulo na internet). Segundo o relatório "Justiça em Números 2014" do Conselho Nacional de Justiça tramitavam na Justiça Paulista 25.515.955 processos em 2013. Ainda segundo esse estudo, os processos de primeira instância representam cerca de $87 \%$ dos casos novos e $96 \%$ dos casos pendentes. Além disso, pela série histórica, desde 2003, os casos novos têm aumentado em média 2,3\% na primeira instância (disponível em:<http://www.cnj.jus.br/images/pesquisas-judiciarias/documentos_jn/estadual.swf >. Acesso em: 28 out. 2014).

${ }^{322}$ Para se ter ideia, segundo dados do STF, foram julgadas, no ano de 2013, 3.413 reclamações, ao passo que, há onze anos, eram julgadas apenas 415. Neste ano de 2014, somente até julho, já foram julgadas 1.986 reclamações. Curioso que, em 2000, foram julgadas 101 ações diretas de inconstitucionalidade, papel natural do Supremo, enquanto, até julho de 2014, julgaram-se 138 ADIs. Assustador mesmo é o volume de recursos extraordinários e de agravos interpostos contra decisões que não recebem aqueles recursos. Aqui, é possível notar os efeitos da instituição do mecanismo da repercussão geral: em 2002, foram julgados 45.769 agravos e 34.396 recursos; em 2013, o Supremo julgou 45.112 recursos extraordinários com agravo e 11.130 recursos extraordinários

(disponível

em:<http://www.stf.jus.br/portal/cms/verTexto.asp?servico=estatistica\&pagina=pesquisaClasse $>$ Acesso em: 26 jul. 2014).

No STJ, o volume também impressiona: em onze anos, de 80.555 recursos especiais, 53.537 agravos e 180 reclamações, julgados em 2002, passou-se a 59.671 recursos especiais, 145.580 agravos e 4.373 reclamações em 2013. Veja-se que, enquanto houve redução do número de recursos especiais, oriunda, provavelmente, da aplicação do mecanismo dos recursos repetitivos, aumentou-se, e muito, o número de agravos e reclamações julgados. Interessa notar, também, que o mesmo relatório estatístico informa que, de um total de 354.843 processos julgados, 77,06\% foram decididos monocraticamente (disponível em:<http://www.stj.jus.br/webstj/Processo/Boletim/sumario.asp>.Acesso em: 26 jul. 2014). 
nas últimas décadas, na tentativa de acelerar a entrega da tutela jurisdicional aos cidadãos $^{323}$. Nesse quadro, várias das soluções alvitradas guardam estreita relação com a chamada "valorização dos precedentes", no que se destacou, nos últimos anos, a permissão dada pela EC45 ao Supremo Tribunal Federal, de edição de verbetes sumulares vinculantes $^{324}$, ao mesmo tempo em que se generalizou a eficácia erga omnes e vinculante para as decisões tomadas em sede de controle concentrado de constitucionalidade.

A sociedade de massas que a globalização intensificou nas últimas décadas foi responsável pela necessária revisão das estruturas do Poder Judiciário e do seu maior instrumento de trabalho, que é o processo. A clássica obra de MAURo CAPPELLETTI e BRYANT GARTH, escrita no final dos anos 1970, foi pioneira ao tratar do acesso à Justiça e dos meios de implementá-lo, dentre os quais está o aprimoramento da representação dos interesses difusos ${ }^{325}$. Mais do que ampliar sua defesa judicial, era necessário adaptar o processo para esse tipo específico de direito, que era indivisível e, portanto, dizia respeito a uma universalidade de titulares.

Na mesma linha, é íntima a relação entre a valorização dos precedentes e a ampliação da eficácia subjetiva das decisões judiciais, esta, por sua vez, ligada à chamada molecularização da tutela jurisdicional. Isto, por se tratar de movimentos voltados a vencer, com esperada justiça, o acúmulo de processos que aportam ano a ano nos fóruns e tribunais do País. Impossível cogitar de uma ampliação dos efeitos das decisões sem, antes, trazer para os processos o signo da tutela coletiva; daí porque é comum o estudo, sob o título genérico de "tutela coletiva", de dois desses fenômenos, quais sejam a "tutela coletiva de direitos" e a "tutela de direitos coletivos" $" 326$.

\footnotetext{
${ }^{323}$ Como a vinculação é direta com relação ao Poder Judiciário e à Administração Pública, há quem afirme que o objetivo principal da criação das súmulas vinculantes, ao menos em um primeiro momento, é "reduzir as demandas em que o Poder Público seja parte, determinando que o Judiciário siga as orientações do Supremo Tribunal Federal e, antes mesmo de que sejam ajuizadas ações, deverá também a Administração Pública segui-las". Assim, estará se prestando à "diminuição e prevenção de demandas, impedindo que a Administração Pública nelas se aventure" (JANSEN, A súmula vinculante como norma jurídica, p. 251).

${ }^{324}$ DINAMARCO coloca essa opção no campo não apenas da técnica, mas sobretudo da política: "Se a questão é político-institucional na medida da reformulação trazida ao sistema de checks and balances constitucionais, era necessário ter a coragem de dar-lhe solução política, porque já se sabia que em regras puramente técnicas de direito processual nenhum resultado eficaz se poderia jamais encontrar" (Súmulas vinculantes, in: Fundamentos do processo civil moderno, t. I, p. 219).

${ }^{325}$ Acesso à Justiça, p. 26-28, 49-66. Já à p. 50, os autores mencionam CHAYES, que definia essas demandas como "litígios de interesse público" em virtude de sua vinculação com importantes assuntos de política pública, que envolvem grandes grupos de pessoas.

${ }^{326}$ ZavASCKI, Processo coletivo, 5. ed.São Paulo: RT, 2011.V. tb., SCARPINELla BUENO, Curso sistematizado de direito processual civil,1. ed., Saraiva, 2010, v. 2, t. III, p. 197-204; NeVES, Ações
} 
Destarte, há muito em comum entre a tutela coletiva de direitos e a tutela dos direitos coletivos, e essa semelhança se encontra justamente nos instrumentos processuais, nas especificidades do processo ${ }^{327}$. Para o que importa ao presente estudo, limitemo-nos a dois pontos fundamentais: a legitimidade (representatividade) e a eficácia das decisões.

Um traço comum entre os processos que veiculam demandas coletivas e os que coletivizam demandas individuais está na eficácia das decisões neles proferidas, que vai além das partes do processo, quando as há. Daí ser natural se colocarem no mesmo patamar de estudo todas as decisões que sejam dotadas de eficácia ultra partes, abarcando as demandas coletivas e o controle de constitucionalidade, em especial o sistema difuso e concreto. E essa marca da coletivização, presente no processo ou no direito nele debatido, parece ser indissociável da ideia de valorização de precedentes no Brasil. É da essência da coletivização das demandas que as decisões nelas proferidas produzam efeitos para além das partes em litígio ${ }^{328}$.

Mas também será imprescindível agregar a tais decisões uma eficácia vinculativa e inibidora de novas demandas, pois a ampliação da eficácia dos julgados é sintoma da molecularização da tutela jurisdicional, cujo mote era exatamente atingir o famoso quadrinômio do direito norte-americano citado por DINAMARCO: igualdade-segurançaeconomia-respeitabilidade. Em busca de acoplar esses quatro adjetivos à tutela jurisdicional é que se idealizaram as grandes alterações no sistema processual nas últimas

constitucionais, p. 6. Certas decisões são naturalmente dotadas dessa eficácia ultra partes. É o caso, de um modo geral, das decisões produzidas no âmbito do processo coletivo, nomeadamente na ação civil pública (art. 16 da Lei 7.347/1985), nas ações coletivas (art. 103 da Lei 8.078/1990) e no mandado de segurança coletivo (art. 22 da Lei 12.016/2009). São ações promovidas em regime de substituição processual, em que os autores, legitimados ativos indicados na lei, atuam em nome próprio na defesa de direitos individuais homogêneos ou transindividuais de interesse de uma pluralidade de pessoas. Assim, pela sua própria natureza, as sentenças nelas proferidas têm eficácia subjetiva que transcende aos partícipes da relação processual. O mesmo fenômeno ocorre no mandado de injunção, especialmente se considerado o perfil normativo-concretizador que hoje lhe atribui a jurisprudência do STF (MI 721/DF, rel. MIN. MARCO AurÉLIO, Pleno, unânime, j. 30/08/2007, DJe 31/10/2008; MI 708/DF, rel. MiN. GILMAR MENDES, Pleno, maioria, j. 25/10/2007, DJe 30/11/2007). As sentenças que dele emanam têm a função de preencher, ainda que provisoriamente, a omissão do legislador, razão pela qual se revestem naturalmente de características reguladoras e prospectivas semelhantes às dos preceitos normativos. Nessa condição, seria inimaginável admitir que, no âmbito da jurisdição injuntiva, fossem produzidas soluções casuísticas e anti-isonômicas para situações semelhantes. É, pois, da essência do mandado de injunção a edição de provimentos jurisdicionais com força material e subjetiva de caráter expansivo.

${ }^{327}$ ZAVASCKI, Processo coletivo, p. 49-51.

${ }^{328}$ Como pondera RODOLFO DE CAMARGO MANCUSO, "[s]e até mesmo na jurisdição singular, voltada para os conflitos intersubjetivos, pode ocorrer uma eficácia expandida da coisa julgada (como nas ações de estado: CPC, art. 472, $2^{\mathrm{a}}$ parte), que dirá no campo da jurisdição coletiva, onde por vezes o julgado se reveste, praticamente, de uma força normativa" (Jurisdição coletiva e coisa julgada, p. 590). Ou seja, é natural que a tutela jurisdicional coletiva seja dotada de força ultra partes, quase normativa. 
décadas. Confira-se a narrativa do autor, na qualidade de participante ativo da história dessas transformações:

"Caminhávamos no sentido da tutela propriamente coletiva, capaz de conter em si a solução para a pretensão de todo um grupo de pessoas (eu, particularmente, estava muito impressionado com as centenas de causas iguais, e tratadas muitas vezes por modos diversos, envolvendo servidores públicos estaduais)".

O que pretendia o grupo encabeçado por ADA PELLEGRINI GRINOVER à época era, então, "uma solução legislativa capaz de impedir que o trato de questões potencialmente portadoras de um impacto de massa prosseguisse no plano puramente individual e sem consideração do interesse coletivo que lhes está à base"329.

Portanto, sem deixar de ressaltar a distinção entre os fenômenos, é relevante notar que a ampliação subjetiva da eficácia da tutela jurisdicional caminha de braços dados com a atribuição de efeitos normativos vinculantes. Mas, antes de ser uma jornada pela valorização das decisões judiciais em prol da isonomia, da segurança e da coesão do sistema jurídico, o objetivo primordial parece ser reduzir, a todo custo, o imenso volume de trabalho que aquela sociedade de massas incorpora ano a ano aos escaninhos do Poder Judiciário.

Constatou-se que o produto jurisdicional do Supremo Tribunal Federal e do Superior Tribunal de Justiça, como resultado desses mecanismos de coletivização ou em decorrência de sua natureza intrínseca (controle concentrado de constitucionalidade), é necessariamente dotado de eficácia ultra partes, atingindo um número indeterminável de pessoas. Por seu turno, viu-se que tem prevalecido a interpretação ampliativa dos artigos 102, I, l, e 105, I, $f$, da CF/1988, de modo a traçar uma linha paralela entre os atingidos pela eficácia da decisão e a legitimidade para ajuizamento da reclamação ali prevista, que culmina com a generalização projetada no novo Código de Processo Civil.

Nesse quadro, resta evidente que aquela molecularização almejada pela coletivização da tutela jurisdicional está francamente ameaçada, caso seja mantida essa linha jurisprudencial do Supremo Tribunal Federal e do Superior Tribunal de Justiça. Isso porque, sem qualquer dúvida, não fosse pela simples questão aritmética de saber que

\footnotetext{
${ }^{329}$ Súmulas vinculantes, p. 220-221. JOSÉ ROGÉRIO CRUZ E TUCCI ressalta a importância econômica, do ponto de vista da previsibilidade e eficiência, gerada pela invocação de precedentes, especialmente em relação a questões de natureza empresarial, as quais, em regra, possuem um campo de reverberação maior (Precedente judicial como fonte do direito, p. 17).
} 
quanto mais legitimados houver mais reclamações haverá, os mesmos problemas de divergência de interpretação cuja solução se buscava com a coletivização uniformizadora voltarão à tona quando da aplicação das normas emanadas dos precedentes judiciais.

Ao tratar das dificuldades enfrentadas pelo juiz ao aplicar as normas jurídicas, MARIA HELENA Dinizenfatiza que a maior delas está na vaguidade dos conceitos jurídicos, a qual, apesar de não poder ser eliminada, pode ser reduzida graças ao emprego de conceitos técnicos, introduzidos por meio de definições explícitas. Todavia, lembra a autora, "sempre restará a possibilidade de que se apresente um objeto atípico que escape ao comando das regras de aplicação do conceito, por mais minuciosas e numerosas que sejam, ${ }^{330}$.

Em outras palavras, sempre que houver um texto a ser interpretado, várias serão as possíveis formas de fazê-lo e muitas serão as conclusões a respeito de seu conteúdo. Ao menos, duas sempre haverá ${ }^{331}$. É inevitável que as regras oriundas dos precedentes, uma vez expressas em texto - tal como as extraímos das decisões judiciais - deem lugar a várias interpretações, pois não podemos pretender que a aplicação dos precedentes seja um processo mecânico ${ }^{332}$.

Eros Grau lembra, com base na doutrina de Tullio AsCarelli, que "os textos normativos carecem de interpretação não apenas por não serem unívocos ou evidentes isto é, por serem destituídos de clareza -, mas também porque devem ser aplicados a casos concretos, reais e fictícios". O caminho a ser trilhado até a concretização do direito é o seguinte: "partindo do texto normativo, no quadro da realidade contemporânea à interpretação, alcançamos a norma jurídica, para então caminharmos até a norma de decisão, aquela que confere solução ao caso" ${ }^{, 333}$.

\footnotetext{
${ }^{330} \mathrm{E}$ arremata: "apenas nas linguagens puramente formais, como a da lógica e a da matemática puras, não surge o problema da vaguidade", justamente porque os conceitos dessas ciências não são empíricos ( $A s$ lacunas no direito, p. 272-273).

${ }^{331}$ A série de indagações formuladas por MANCuSO (Divergência jurisprudencial e súmula vinculante, p. 27) vale muito bem aqui: "é plausível que a isonomia aplique-se à norma legislada, mas não atue em face da norma judicada? É admissível ter-se uma dualidade no conteúdo axiológico da norma, por modo que ela seja igual para todos, enquanto abstratamente posta no ordenamento, mas torne-se variável e cambiante quando vem a ter o seu momento judiciário?” Ou seja, é possível controlar a especialização de normas gerais? Não seria mais razoável aceitar que não existe regra geral infensa a especializações?

${ }^{332} \mathrm{Cf}$. Ferreres Comella, Sobre la posible fuerza vinculante de la jurisprudencia, inFerrereseXiol. Ob. cit., p. 78.

${ }^{333}$ Por que tenho medo dos juízes, p. 33.
} 
É do ideário da aglutinação de demandas e da enfatização da força dos precedentes judiciais a possibilidade de as decisões dos tribunais, especialmente os constitucionais, gerarem, em regra, efeitos para além do processo para o qual foram proferidas. Segundo se espera, então, uma decisão do Supremo Tribunal Federal que surta efeitos erga omnes e vinculantes deverá ser respeitada por todos, sobretudo pelos demais órgãos do Poder Judiciário.

Todavia, graças à cultura instituída no Brasil, que não é habituada a contrastar precedentes, a sua aplicação será feita como se de lei se tratasse, gerando, assim, ao menos em tese, a possibilidade de haver mais de uma forma de interpretar. Especificamente no caso das súmulas, sintéticas por natureza, a verdade é que o modo como se escrevem tem íntima relação com a elasticidade ou não das interpretações possíveis ${ }^{334}$.

Não é por outra razão que o Supremo Tribunal Federal e o Superior Tribunal de Justiça têm aceitado que, em cada caso concreto e mediante a aplicação do princípio da razoabilidade e da regra da proporcionalidade, os juízes possam descumprir decisões tomadas em sede de controle concentrado de constitucionalidade pelo STF - decisões estas dotadas de efeitos erga omnes e vinculantes. Exemplos mencionados por ALESSANDRA PIGNATARI $^{335}$ têm como paradigma decisões do STF nas quais houve a declaração da constitucionalidade de dispositivos que limitavam a concessão de medidas liminares a respeito de determinadas matérias de nodal interesse da administração pública ${ }^{336}$.

\footnotetext{
${ }^{334}$ Como afirma FerReres COMELLA, a segurança jurídica, a igualdade e a imparcialidade ou objetividade estão em maior ou menor risco na exata medida em que haja maior ou menor espaço de indeterminação no sistema jurídico. Ou seja, "cuanta mayor indeterminación haya en el sistema jurídico (antes que surja el complemento jurisprudencial), mayor es la probabilidad de que emerjan discrepancias entre los jueces y, por tanto, mayor es el riesgo que corren los referidos valores" (ob. cit., p. 46-47). Portanto, os problemas que surgem são os mesmos da interpretação dos textos legais (ITURRALDESESMA, Victoria, Razonamiento judicial a partir de precedentes, in:GARCIA, Ramón Ortega (coord.).Teoría del derecho y argumentación: ensayos contemporáreos, p. 366).

335 No STF: Rcl-AgR 1067/RS, rel. Min. OCtÁvio Gallotti, DJ 03/09/1999; Rcl. 3935/CE, rel. Min. SePúlvedA PertenCE, DJ 10/08/2006. No STJ: REsp-AgR 397.275/SP, rel. Min. FrancisCo FALCÃo, DJ $1 . \% / 12 / 2002$ (Efeitos processuais no controle judicial de constitucionalidade, p. 283-284).

${ }^{336}$ MC na ADIn 223-6/DF, rel. MiN. SEPÚLVEDA PERTENCE, DJ 29/06/1990 (nesse julgamento, em que se discutia a constitucionalidade da proibição de concessão de liminar contra o Poder Público em determinadas matérias, o tribunal entendeu por não declarar a inconstitucionalidade em abstrato, mas permitir que juízes o façam em concreto caso a caso incidentalmente, conforme dispositivo: "Medida cautelar deferida, em parte, por maioria de votos, para se suspender, 'ex nunc', e com efeito vinculante, até o julgamento final da ação, a concessão de tutela antecipada contra a Fazenda Pública, que tenha por pressuposto a constitucionalidade ou inconstitucionalidade do art. 1. ${ }^{\circ}$ da Lei n. 9.494, de 10.09.97, sustando-se, igualmente 'ex nunc', os efeitos futuros das decisões já proferidas, nesse sentido". e e ADC/MC 4, rel. MIN. SYDNEY SANCHES, DJ 21/05/1999.
} 
A autora faz questão de alertar que essa "relativização do efeito vinculante", da mesma forma que a chamada "relativização da coisa julgada",

"traz o confronto entre o risco de o sistema conviver com sentenças injustas e o risco de se instaurar a insegurança jurídica (no caso, com o descumprimento desordenado de decisões de controle abstrato, cuja autoridade e obrigatoriedade de observância também se alçam em nível constitucional)" ${ }^{337}$.

$\mathrm{Na}$ realidade, todavia, não se trata de aceitar um descumprimento de decisão vinculante do STF, mas de reconhecer as limitações inerentes a qualquer decisão judicial no que diz respeito à sua aplicação para casos futuros em um sistema que não está acostumado a encontrar a ratio decidendie tampouco a aplicá-la.

Em estudo a respeito da súmula vinculante, traçando um paralelo entre o Direito Inglês e o Direito Brasileiro, EDUARDO JOBIM e LuCIANO BENETTI TiMM concluem que é necessário refletir sobre

"uma nova forma de redação das súmulas do STF, para que sejam mais descritivas, mais detalhadas, mais analíticas, de modo que o Tribunal possa permitir aos advogados e juízes argumentarem seus casos em cima destes precedentes para casos realmente semelhantes, mas tratando diferentemente situações diversas, evitando que se caia numa absoluta padronização de decisões por computador em julgamentos em série"338.

Constatam-se dois problemas distintos, cuja solução não parece ser imediata e, por isso, não atenderá os anseios de urgência do legislador das reformas. Um se encontra na redação do texto, que nem sempre se restringe às questões específicas decididas nos precedentes - as quais, em regra, dadas as circunstâncias dos casos antecedentes, são uma concretização da norma original positivada ${ }^{339}$. Nesse contexto, uma interpretação deficiente ou parcial, derivada, por exemplo, da falta de debate adequado quando da elaboração do verbete, pode fazer que ele não reflita a essência daqueles julgados originais (ratio decidendi).

\footnotetext{
${ }^{337}$ Efeitos processuais no controle judicial de constitucionalidade, p. 285.

${ }^{338}$ A súmula vinculante no direito brasileiro. estudo comparativo com o direito inglês, p. 926.

339 Sobre essa concretização, TARUFFO, ao tratar das massime da Corte de Cassação italiana, assim se expressa: "La caratteristica più importante delle massime è che si tratta di enunciazione, concentrate in una $o$ in poche frasi, che hanno ad oggetto regole giuridiche. Queste regole hanno solitamente un contenuto più specifico rispetto al dettato testuale della norma di cui constituiscono una interpretazione, ma sono pur sempre formulate come regole, ossia come enunciazioni generali di contenuto precettivo" (Precedente $e$ giurisprudenza, p. 15). O novo Código de Processo Civil, ao detalhar como se deve cumprir o princípio da motivação da sentença (art. 486) e ao traçar o procedimento para produção de precedentes (arts. 924 a 926), especialmente o $\$ 2 .^{\circ}$ do art. 924: "Ao editar enunciados de súmula, os tribunais devem ater-se às circunstâncias fáticas dos precedentes que motivaram sua criação".
} 
Essa questão não é ignorada pelo Supremo Tribunal Federal, que, em julgamento que se encerrou recentemente, debateu-a às claras. $\mathrm{Na}$ ocasião, assim se manifestou o Ministro ROBERTO BARROSO:

"na medida em que nós venhamos a expandir esse papel dos precedentes - para usar o verbo utilizado pelo Ministro Teori -, teremos que produzir decisões em que a tese jurídica afirmada seja mais nítida - o que, no Direito anglo-saxão, se chama holding. Muitas vezes - a meu ver, esse é o papel da ementa, e tenho procurado discutir isso -, era preciso que ficasse mais claro, prima facie, qual foi a tese jurídica afirmada pelo Supremo" 340 .

O segundo problema correlato diz com a aplicação do precedente em si. Aqui, nos casos de súmula vinculante, quanto mais houver descompasso entre os precedentes e o verbete sintetizador, maior a chance de a norma produzida ser genérica e lacônica demais, impedindo "comparações, analogias, distinções e argumentações para fatos novos"341.

Não é por outro motivo que a doutrina costuma diferenciar as "súmulas vinculantes" do Direito Brasileiro dos precedentes dos países de common law, afirmando que aquelas valem pelo seu enunciado genérico e não pelos fundamentos que o embasaram, como acontece nos países de tradição costumeira ${ }^{342}$. Daí ser necessário refletir, também, sobre a forma de aplicar a súmula vinculante, que não pode abrir mão da análise dos precedentes que a originaram, bem como dos fatos que serviram de base ao julgamento.

A respeito da interpretação de precedentes, Victoria ITURRALDE SESMA desenha dois modelos: um, a que chama de "modelo de regras", no qual a ratio decidendi tem valor de precedente com a obrigação de ser aplicada a casos futuros, e outro, chamado de "modelo da analogia", no qual um caso é considerado como exemplo significativo e correto para guiar decisões futuras em casos similares. Para a autora, ambos os modelos apresentam problemas semelhantes.

No primeiro caso, o entrave mais considerável está na formulação da ratio decidendi, já que

\footnotetext{
${ }^{340}$ Trata-se da já mencionada Rcl. 4335/AC, rel. Min. GILMAR MENDES, j. 20/03/2014, DJe 22/10/2014. ${ }^{341}$ JOBIM ETIMM, op. cit.

${ }^{342}$ GEORGES ABBOUD, assemelhando as súmulas mais aos assentos portugueses que aos precedentes do common law, afirma que a súmula vinculante, por sua vez, da mesma forma que o assento português, desvincula-se dos casos que a originaram e se impõe como um texto normativo de vinculação geral e abstrata para casos futuros - tal qual a lei, "possui dimensão atemporal" (ABBOUD, Georges: Precedente judicial versus jurisprudência dotada de efeito vinculante, in: WAMBIER, Teresa Arruda Alvim (coord.). Direito jurisprudencial. São Paulo: RT, 2012, p. 520.
} 
"lasdecisiones que consituyen precedentes no se formulan como normas generales, y loque vincula al juez no es el fallo ensí, sino la ratio decidendi; ratio que solo puede obtenerse a partir del dispositivo de la sentencia en relación con la estructura jurídica de los hechos y la decisión",343.

No segundo modelo, a dificuldade maior está na descrição dos casos e em saber se há ou não a similitude suficiente entre o precedente e o caso em julgamento.

Bem se nota que, seja qual for o modelo de aplicação de precedentes, ela não escapará da interpretação de fatos e norma, ora com maior ênfase nos primeiros ora com foco na segunda, e da comparação entre casos. Importa ter consciência de que, conforme lição de THOMAS DA RoSA DE BustamanTE,

"o modo de raciocínio ou pensamento do jurista prático que realiza as atividades de interpretação e aplicação de precedentes judiciais encontra similaridades suficientes para justificar a pretensão de se consagrar uma única teoria dos precedentes judiciais, em especial uma teoria normativa, válida para ambas as tradições jurídicas"344.

Isso significa que o método de aplicação do precedente, seja sumulado ou não, é praticamente idêntico ao utilizado pelo aplicador da lei. Em um e outro casos, é necessário levar em conta os fatos e a norma que envolve a questão debatida. De conseguinte, imaginar que a simples ampliação da eficácia das decisões dos tribunais superiores, a ponto de se lhe atribuir caráter vinculante, será capaz de reduzir a carga de trabalho dessas Cortes é um otimismo que beira a ingenuidade. Os mecanismos de barragem de recursos a esses tribunais têm funcionado de forma bem mais eficaz, a demonstrar que o remédio está mesmo na redução dos remédios.

As "súmulas de jurisprudência" são instituto com DNAdo civil law, idealizado para organizar, bem ao modo dos dispositivos da lei escrita, as decisões judiciais, criado por juízes treinados nesse sistema jurídico, acostumados, portanto, a fazer o caminho da

\footnotetext{
${ }^{343} \mathrm{~A}$ autora elenca os problemas que envolvem a ratio decidendi no modelo de interpretação de precedentes como é o nosso; são eles: (a) a própria dificuldade de se definir o conceito de ratio decidendi (questão conceitual); (b) a dificuldade de distinguir, nas decisões, a ratio dos obiter dicta; (c) qual o método de se determinar a ratio; (d) a possibilidade de uma mesma decisão vários intérpretes extraírem variadas ratio. Lembra, ainda, a autora, que é raro os tribunais estabelecerem expressamente qual é a ratio com base na qual decidiram (Razonamiento Judicial a partir de precedentes, in:GARCIA, Ramón Ortega (coord.). Teoría del derecho y argumentación: ensayos contemporáreos, p. 355 e 360).

${ }^{344}$ BustamanTE, Teoria do precedente judicial: a justificação e a aplicação de regras jurisprudenciais, $\mathrm{p}$. 114. Seguindo esse pensamento, v. HeRMES ZANETI JR., O valor vinculante dos precedentes, p.349-351.
} 
subsunção dos fatos à norma jurídica geral. Talvez aqui esteja a razão pela qual os fins almejados não se atingem: porque o mecanismo utilizado não funciona em um sistema cujos sujeitos aplicadores do Direito não estão habituados a construir um precedente demonstrando a mais não poder seus fundamentos jurídicos - e tampouco a aplicá-lo, encontrando na história dos casos julgados a norma-matriz a ser aplicada na hipótese semelhante ${ }^{345}$.

Mas o problema está na falsa ilusão de que se criará no Brasil um respeito à jurisprudência - vertical e horizontal - por imposição legislativa. Os juristas do common law têm a tradição e a necessidade de buscar, das decisões judiciais anteriores, as normas a serem aplicadas aos casos atuais. Nós, entretanto, temos por balda procurar a norma aplicável ao caso sob análise nos códigos e nos compêndios legislativos.

Quando procuramos um precedente, quase sempre nos limitamos à leitura da ementa, a qual, com muita frequência, não espelha todo o rico debate havido no julgamento e tampouco os fatos que serviram de estofo para o decisum. No mais das vezes, contentamonos com citar um julgado - que nem sempre representa o entendimento do tribunal, quando há um entendimento consolidado -, e, o que é pior, muitos juízes também se contentam, de modo que é difícil, na nossa tradição, até mesmo descobrir qual é a jurisprudência de determinado órgão jurisdicional a respeito daquela questão jurídica.

Na verdade, a chamada "valorização dos precedentes" vem a reboque das tentativas de redução da carga de trabalho. A pretexto de homenagear a isonomia, a segurança jurídica e a coerência da ordem jurídica ${ }^{346}$, todos os instrumentos processuais desenvolvidos para garantir maior respeito à jurisprudência dos tribunais superiores vêm acompanhados de um viés aglutinador de demandas e da ampliação da eficácia das

\footnotetext{
${ }^{345}$ JOSÉ IGNACIO BOTELHO DE MESQUITA adverte ao fato de que "tanto a uniformização de jurisprudência como a formação jurisprudencial do direito correm o risco de transformar o direito em um complexo de normas criadas em laboratório, impermeáveis às exigências da nação, convertendo-se em um direito construído a partir da pura técnica jurídica, cada vez mais distanciado do fato concreto". A preocupação do autor está posta no "método de que deriva a produção da Súmula [coletânea de verbetes], tendo em vista o nível de contribuição que pode receber da atividade das partes no processo, tanto na sua formação com na sua modificação" (Súmula da Jurisprudência Predominante no STF, p. 224).

${ }^{346}$ MARINONI aponta, ainda, mais as seguintes razões para seguir precedentes: garantia da imparcialidade, possibilidade de orientação jurídica, definição de expectativas, desestímulo à litigância, favorecimento de acordos, facilidade de aceitação da decisão, racionalização do duplo grau de jurisdição, contribuição à razoável duração do processo, economia de despesas e maior eficiência do Poder Judiciário (Precedentes obrigatórios, p. 120-190). Nota-se que esses motivos todos são, na verdade, decorrência lógica dos três primeiros - segurança jurídica, isonomia e coerência da ordem normativa - e neles supomos estarem abarcados.
} 
decisões desses tribunais. E um método muito usado é pinçar um caso "representativo da controvérsia”, suspender os demais (que tratem - supostamente - da mesma controvérsia) e, depois, aplicar a decisão tomada no caso pinçado a todos os demais, atribuindo a ela efeito semivinculante.

Tal método visa a dar legitimidade à ampliação de eficácia da decisão, na medida em que se alarga o debate no processo selecionado, com a permissão de ingresso de terceiros interessados. Não que isso signifique, necessariamente, que a solução dada ao caso selecionado enfrentará "todos os principais argumentos relacionados à questão de direito posta na moldura do caso concreto", como era recomendável ${ }^{347}$. Como já dito acima, esse processo predeterminado na lei de elaboração de precedentes constitui uma das grandes diferenças entre os sistemas, já que é completamente diverso do modo como são concebidos os precedentes do common law. Aqui, preconcebidos; lá, reconhecidos.

Como pondera o Ministro Cezar Peluso, ao analisar o cabimento de agravo de instrumento ou de reclamação ao STF nos casos de decisão da origem a respeito de acórdão julgando recurso extraordinário com repercussão geral:

“[...] a admissibilidade do agravo de instrumento ou da reclamação recompõe o sistema anterior [...] porque todas as decisões serão suscetíveis de ataque [...] porque não se pode, ao que me parece, enfocar apenas a hipótese em que o tribunal erre, sob a ótica de que aplicou o precedente onde não devia. Eventualmente, o tribunal pode tê-lo aplicado, pensando que era correto, e a outra parte pode achar que estava errado. Em qualquer dessas hipóteses, portanto, sempre que o tribunal $a$ quo aplicar a decisão ou a tese do Supremo, uma das partes vai sempre poder alegar que não se está cumprindo a decisão da Corte",348.

\footnotetext{
${ }^{347}$ Cf. MARINONI, ob. cit., p. 216. Como lembra o autor, "[a]té porque os contornos de um precedente podem surgir a partir da análise de vários casos, ou melhor, mediante uma construção da solução judicial da questão de direito que passa por diversos casos" (idem, ibidem). Lembrando que, para o common law, o precedente é sempre uma única decisão. Segundo RENÉ DAVID, "devemos abandonar a ideia tão corrente de que o direito inglês é um direito consuetudinário. Esta ideia advém para muitos juristas do continente europeu da admissão da alternativa: ou o direito é um direito escrito, fundado sobre os códigos, ou não é um direito escrito e, por conseguinte, é consuetudinário; é um direito jurisprudencial. A common law teve por efeito fazer desaparecer o direito consuetudinário na Inglaterra, existente nos costumes locais. $\mathrm{O}$ atual funcionamento da regra do precedente ignora a noção, aparentada com a do costume, de jurisprudência constante (ständige Rechtsprechung); o precedente obrigatório é constituído por um único acórdão, dado por uma jurisdição de determinada categoria" (Os grandes sistemas do direito contemporâneo, p. 441-442).

${ }^{348}$ AI 760.358-QO/SE, rel. MIN. GILMAR MENDES, j. 19/11/2009, DJe 11/02/2010. Na sessão plenária do dia 16/10/2014, na qual o STF o aprovou a conversão do verbete $n^{\circ} 339$ da Súmula no verbete $n^{\circ} 37$, o MIN. ROBERTO BARROSO foi categórico ao anunciar: "vai chover reclamação". Trata-se da súmula que dispõe sobre a impossibilidade de o Poder Judiciário aumentar vencimentos dos servidores públicos sob o fundamento de isonomia: "Não cabe ao poder Judiciário, que não tem função legislativa, aumentar vencimentos de servidores públicos sob o fundamento de isonomia". Pela amplitude e generalidade do texto,
} 
De fato, o objetivo primordial das últimas reformas processuais tem sido desafogar os tribunais superiores, que deveriam se dedicar mais à sua função constitucional de salvaguardar a Constituição Federal (STF) e homogeneizar a interpretação da lei federal (STJ, TSE e TST). Para os idealizadores das reformas, essas Cortes gastam muito de seu tempo decidindo questões que são de importância relativa, considerando as grandes causas que aguardam na fila, anos a fio, para serem julgadas ${ }^{349}$.

com características muito mais de princípio que de regra, fácil imaginar a quantidade de interpretações possíveis e, em consequência, o sem-número de decisões que podem ser objeto de reclamação por suposta violação do preceito.

${ }^{349}$ Nas palavras do MiN. GILMAR MENDES, ao analisar a questão do cabimento ou não de agravo contra decisão de tribunal que aplica decisão do STF relativa à repercussão geral: "A situação que ora se examina sinaliza o início da segunda fase da aplicação da reforma constitucional que instituiu a repercussão geral, dando origem a um novo modelo de controle difuso de constitucionalidade no âmbito do Poder Judiciário. Este novo modelo já produziu efeitos expressivos na sua primeira fase de implantação, mediante os mecanismos de seleção de processos representativos da controvérsia - nesta Corte e nos Tribunais de origem -, de sobrestamento de processos múltiplos e de análise da repercussão geral de 186 questões constitucionais. Ao compararmos a distribuição de processos nos seis primeiros meses do ano de 2007 com a distribuição, no mesmo período, deste ano, percebemos uma redução na ordem de 63,6\%. Reduziu-se, também, o número de processos em tramitação em aproximadamente $29 \%$ nesse período. Iniciamos o julgamento de mérito nos temas com repercussão geral reconhecida. Atualmente, 33\% das questões constitucionais já foram definitivamente decididas. A segunda etapa da reforma, em que agora ingressamos, é a que decorre da aplicação aos processos múltiplos, sobrestados ou não, das decisões de mérito pacificadas pelo STF. Trata-se da utilização dos leading cases para a solução de processos que versam sobre idênticas questões constitucionais e que, segundo o regime legal, não devem ser remetidos a esta Corte, e, sim, nos termos do $\$ 3 .^{\circ}$, do art. 543-B, solucionados no âmbito dos tribunais e turmas recursais de origem, mediante juízo de retratação ou declaração de prejuízo [...]. Esta é a situação em que se insere a hipótese dos autos. A Turma Recursal do Juizado Especial Federal de Sergipe declarou prejudicado o recurso extraordinário interposto [...]. Desse reconhecimento de que o recurso estava prejudicado, a parte que restou vencida no processo interpõe o presente agravo de instrumento. Cabe indagar a compatibilidade da forma de impugnação utilizada ao novo regime de controle difuso de constitucionalidade. Nesse caminho, desde logo chamo a atenção para a necessidade de se interpretar a questão jurídica que aqui trago à apreciação à luz da Constituição e do novo sistema que pretende racionalizar o uso do recurso extraordinário [...] uma vez, submetida a questão constitucional à análise da repercussão geral, cabe aos tribunais dar cumprimento ao que foi estabelecido, sem necessidade de remessa dos recursos individuais. Caso contrário, se o STF continuar a ter que decidir caso a caso, em sede de agravo de instrumento, mesmo que os Ministros da Corte apliquem monocraticamente o entendimento firmado no julgamento do caso-paradigma, a racionalização objetivada pelo instituto da repercussão geral, de maneira alguma, será alcançada [...]. Houve uma opção política na reforma constitucional. Temos que assumir definitivamente a função de Corte Constitucional e abandonar a função de Corte de Revisão. Temos que confiar na racionalidade do sistema e na aplicação de nossas decisões pelas Cortes de origem. Ademais, há mecanismos para a identificação e a reparação de situações teratológicas. O sistema processual as admite. A coisa julgada inconstitucional é inexigível e enseja ação rescisória. Contamos com ações constitucionais, contamos com diversos mecanismos de controle concentrado de constitucionalidade. Temos instrumentos fortes e largos o suficiente para abrir mão desse papel revisional individual que, por tantos anos, restringiu as condições desta Corte de debruçar-se sobre um maior número de questões constitucionalmente relevantes [...]. A decisão, que foi do legislador e não nossa, de não mais submeter ao STF, individualmente, os recursos múltiplos, precisa estar cercada de mecanismos que a tornem efetiva, especialmente nestas primeiras de decisões sobre procedimento [...]. Sob pena de subverter-se toda a lógica do sistema, não cabe agravo de instrumento de cada decisão que aplica a jurisprudência desta corte em cumprimento do disposto no §3..$^{\circ}$ do art. 543-B, do Código de Processo Civil [...]. No caso dos autos, porém, por tudo que já foi exposto, a possibilidade de reexame do que ficou assentado no decreto de prejudicialidade insere-se no âmbito de competência do Tribunal de origem, não cabendo agravo dessa decisão. Tampouco será cabível a conversão do agravo em reclamação, o 
É inegável existirem duas formas de fazer cumprir uma norma: ou pela coerção, que lhe deve ser intrínseca; ou pela força externa adquirida pelo reconhecimento por parte da coletividade à qual foi endereçada de ser ela portadora de um valor justificante. Ninguém discute que a lei e as decisões judiciais devem ser cumpridas; entretanto, como já mencionamos, a linguagem na qual são produzidas, à medida que se abstrai e generaliza, propicia um sem-número de interpretações possíveis, as quais dificultam sobremaneira o controle efetivo de seu cumprimento ${ }^{350}$.

Por outro lado, não faz sentido dar mais importância a precedentes judiciais que à lei e à própria Constituição Federal; na pior das hipóteses, quando muito, os precedentes vinculantes se equivalem à lei. Ora, sendo assim, qual a razão para alguém que tem contra si uma decisão (supostamente) violadora de um precedente possuir, ao seu dispor, um atalho processual até o STJ ou o STF, enquanto outros - a maioria, aliás - devem passar pelo calvário que é ter um recurso especial ou extraordinário admitido?

Como se demonstrou, o procedimento da reclamação, dada a natureza de ação pela qual tem sido tratada, é muito mais simples que o de qualquer um desses dois recursos constitucionais $^{351}$. Basta mencionar que o autor não encontrará pela frente o verdadeiro arsenal de obstáculos exigidos para a admissão daqueles recursos, como

queimplicaria, da mesma forma, a remessa individual de processos, em total desconformidade com o novo sistema de controle difuso de constitucionalidade”. No julgamento, após pedir vista, a MIN. ELLEN GRACIE manifestou-se no mesmo sentido: "Penso não ser adequada a ampliação da utilização da reclamação para correção de equívocos na aplicação da jurisprudência desta Corte aos processos sobrestados na origem. Isso acarretaria aumento na quantidade de processos distribuídos e desvirtuamento dos objetivos almejados com a criação da repercussão geral. Esse aumento já está ocorrendo. Enquanto nos primeiros oito meses do ano passado foram distribuídas 702 reclamações, até agosto deste ano recebemos 1.422 reclamações. A prosseguir esse índice de incremento, no futuro provavelmente teremos que pedir ao Congresso Nacional que legisle em relação à aplicação do instituto da repercussão geral à reclamação" (AI 760.358-QO/SE, rel. MIN. GILMAR MENDES, j. 19/11/2009, DJe 11/02/2010).

${ }^{350}$ Embora não se conheça estudo empírico também nesse ponto, supõe-se que o cumprimento de determinado comando normativo, quando oriundo do reconhecimento de um valor intrínseco àquela norma, é muito mais eficaz por pressupor uma vontade geral prévia à própria existência da regra, de modo que a tendência é não se anteporem obstáculos à sua efetivação.

${ }^{351}$ Exige-se, como condição da ação, além dos requisitos específicos de cada hipótese legal, apenas a identidade estrita com o parâmetro de controle e não estar sendo utilizada como sucedâneo recursal ou substituto de ação rescisória. Assim:"'O remédio constitucional da reclamação não pode ser utilizado como um (inadmissível) atalho processual destinado a permitir, por razões de caráter meramente pragmático, a submissão imediata do litígio ao exame direto do Supremo Tribunal Federal" (STF,Rcl. 6534 AgR/MA, Plenário, rel. MIN. CELSO DE MELlO, j. 25/09/2008, DJe 19/10/2008). "É que a reclamação constitucionalmente vocacionada a cumprir a dupla função a que alude o art. 102, I, "l", da Carta Política (RTJ 134/1033) - não se qualifica como sucedâneo recursal, nem configura instrumento viabilizador do reexame do conteúdo do ato reclamado, eis que tal finalidade revela-se estranha à destinação constitucional subjacente à instituição dessa medida processual" (STF, Rcl. $2107 \mathrm{AgR} / \mathrm{SC}, 2 .^{a} \mathrm{~T}$., rel. MIN. CELSO DE MELLO, j. 05/08/2014, DJe 02/09/2014). 
prequestionamento, confronto analítico de casos, necessidade de haver violação direta do texto constitucional etc. Em outras palavras, não faltarão exemplos de inconstitucionalidades que nem sequer chegarão ao Supremo Tribunal Federal nem de ilegalidades que jamais serão conhecidas pelo Superior Tribunal de Justiça, enquanto esses tribunais estarão assoberbados analisando milhares de reclamações tiradas contra decisões, sentenças e acórdãos proferidos Brasil afora.

Destarte, os precedentes judiciais serão tão mais respeitados e seguidos quanto mais sejam capazes de representar uma tese valorizada tanto pelos jurisdicionados como pelos demais órgãos do Poder Judiciário. Decisões bem fundamentadas e que representem a melhor elaboração técnica e sistemática acabam por adquirir respeitabilidade e fumos de norma geral e aplicável a casos semelhantes. Afinal, em primeiro lugar, o prolator da decisão (leia-se, Poder Judiciário) deve se convencer do acerto da solução a que chegou ${ }^{352}$.

Imperioso, portanto, reconhecer que a legitimidade dos precedentes lhes é anterior, como se estivesse latente, aguardando a elaboração da norma, a suprir a lacuna do sistema legal. Seguir ou não o quanto decidiram o Supremo Tribunal Federal ou o Superior Tribunal de Justiça dependerá muito mais desse reconhecimento que do receio de submeter a decisão ao crivo desses tribunais seja lá por que instrumento for.

Na linha da diferenciação defendida por DANIEL MitidiERo entre Cortes superiores e Cortes supremas, permitir o controle dos precedentes do STJ e do STF mediante o uso da reclamação constitucional é aplicar mecanismo típico de uma Corte superior para controlar decisões emanadas de Cortes supremas. Em outros termos, se, de um lado, rumamos para reforçar a natureza de Cortes supremas desses dois tribunais superiores, de outro, ao abrirmos suas portas para as reclamações, estaremos enfatizando seu papel de Cortes superiores, que é reativo e "pressupõe a existência de uma violação ao Direito já ocorrida, sendo sua tarefa sancioná-la e, quando possível, neutralizar ou eliminar os seus efeitos mediante cassação ou reforma da decisão" ${ }^{\text {353. }}$.

\footnotetext{
${ }^{352}$ Mesmo reconhecendo que os precedentes no Brasil não são dotados de força vinculante (em regra), TUCCI bem pontua que "cabe aos magistrados outorgar aos precedentes dos tribunais superiores revestidos da marca da definitividade o valor e a influência aptos a orientar os órgãos inferiores e não desrespeitar, sem justificação plausível, a função nomofilácica àqueles atribuída pela Constituição Federal" (Precedente judicial como fonte do direito, p. 277).

${ }^{353} \mathrm{Ob}$. cit., p. 42-43. Mais à frente, o autor afirma que a unidade do Direito, para as cortes ditas superiores, chega a ser um desvalor, já que estanca o influxo vivificador que a interpretação jurisdicional exerce sobre o Direito, sendo por isso mesmo contraproducente e nessa medida indesejável (idem, ibidem, p. 46).
} 
Entretanto, não se pode esperar que a cultura jurídica brasileira passe, como que por mágica, a partir do dia seguinte à promulgação de uma lei reformadora do sistema processual ou de uma emenda constitucional que seja, a tratar as decisões judiciais como se leis fossem ${ }^{354}$. Respeitar (rectius: cumprir) decisões judiciais tomadas em processos dos quais não participamos de modo efetivo demandará profunda mudança de paradigma.

Como bem conclui MITIDIERO, mais do que uma reforma legislativa,

"semelhante projeto exige para sua realização uma profunda reforma cultural, sem a qual nossa ordem jurídica jamais será pautada pela igualdade, pela segurança e capaz de prestar uma tutela adequada, efetiva e tempestiva aos direitos [...], jamais será capaz de inspirar mútua confiança entre as pessoas e as instituições, sem a qual inexistem condições para o livre exercício dos direitos".

Em primeiro lugar, é preciso repensar a forma de ensinar o Direito. Os currículos das faculdades deverão ser revistos para passarem a conter momentos de discussão dessa nova linguagem, desse novo modo de ver (e ler) as decisões judiciais e, sobretudo, o sistema jurídico-processual (direito de ação, recursos e meios de impugnação das decisões judiciais). A norma jurídica produzida pelo legislador deverá dividir espaço com os precedentes judiciais no núcleo dos estudos de introdução à ciência do Direito ${ }^{355}$.

\footnotetext{
${ }^{354}$ A experiência inglesa não é diferente, segundo RENÉ DAVID: “A lei desempenha, na Inglaterra de hoje, uma função que não é inferior à da jurisprudência. Contudo, o direito inglês, nas atuais circunstâncias, continua a ser um direito essencialmente jurisprudencial por duas razões: porque a jurisprudência continua a orientar o seu desenvolvimento em certos setores que se mantêm muito importantes e, por outro lado, porque, habituados a séculos de domínio da jurisprudência, os juristas ingleses não conseguiram até a presente data libertar-se da sua tradição. Para eles, a verdadeira regra de direito somente existe vista através dos fatos de uma espécie concreta e reduzida à dimensão necessária à resolução de um litígio". Por esses motivos, para o autor, é "difícil modificar o estado de espírito dos juízes e dos juristas com relação à lei e não se pode esperar fazê-lo através da promulgação de novas regras técnicas" (ob. cit., p. 435-436). O mesmo se dá nos EUA, exceção feita ao Estado da Louisiana, de tradição romano-germânica. Segundo DAVID, "os códigos americanos não são o equivalente dos nossos códigos. São interpretados de modo muito diferente destes. Num país de common law não se consideram como plenamente normais regras que não sejam regras jurisprudenciais; vê-se nos códigos uma simples obra de consolidação, mais ou menos bem realizada [...] Presume-se que o objetivo do legislador, no código, seria reproduzir a regra anterior, proposta pela jurisprudência. A lei não tem sentido enquanto não for interpretada pelos tribunais. É excepcional ver acórdãos estatuírem, sem invocação de precedentes judiciários, pela simples aplicação de uma lei” (ob. cit., p. 506). THOMAS DA ROSA DE BUSTAMANTE qualifica a atividade legislativa exercida no common law, em parte significativa do direito privado, de "assistemática, fragmentária e parasitária do direito consuetudinário e jurisprudencial, na medida em que apresenta em muitos casos um caráter ad hoc e se vale de conceitos que só fazem sentido se interpretados à luz do case law". Por essa razão, levanta a hipótese de que a diferença das duas tradições jurídicas esteja, não na forma de os juízes aplicarem o Direito, mas no "modo como o legislador se comporta"(ob. cit., p. 115).

${ }^{355}$ ONODERA lembra que, para viabilizar a doutrina do staredecisis, "primeiro, houve a necessidade da adequada preparação do profissional, desde a faculdade, para o adequado manuseio da jurisprudência. Christopher Langdell, então reitor da Universidade de Harvard, idealizou o método de estudo de cases, no qual estimulava os alunos a estudar a evolução dos precedentes, a razão de ser da sua mudança oupreservação
} 
Não menos importante é que os sujeitos operadores do sistema jurídico - advogados, promotores e juízes -, formados em outro momento histórico, passem a valorizar os precedentes judiciais. Talvez seja indevido estabelecer uma ordem para saber quem deverá valorizá-losprimeiro, mas o fato é que o exemplo deverá vir do Poder Judiciário.

Mas, na realidade, os juízes serão os grandes artífices da mudança: sem a consciência de que suas decisões devem obediência irrestrita ao devido processo legal e ao dever de motivação, que animam o estado democrático de direito, será inviável qualquer tentativa de ampliação da força vinculante dos precedentes. O poder que se lhes está sendo atribuído há de ser acompanhado pela efetiva responsabilidade: de produzir normas-decisões fundamentadas, de uniformizar entendimentos e de, por fim, aplicá-los tendo em mira o equilíbrio entre estabilidade e segurança de um lado, e elasticidade e justiça de outro ${ }^{356}$.

Os advogados e promotores, por sua vez, deverão evitar lides contrárias ao que estiver sendo, fundamentadamente, decidido pelo Poder Judiciário, máxime pelo Supremo Tribunal Federal e pelo Superior Tribunal de Justiça. A propósito, o sistema deve contar com punições exemplares de atos de litigância de má-fé, em especial os decorrentes de ajuizamento de demanda que afronte de modo frontal e evidente o quanto decidido por aqueles Tribunais.

Na linha dos Law Reports do common law ${ }^{357}$, não se pode olvidar de mecanismos eficientes de catalogação e consulta dos precedentes, que permitam, ao operador verificar

e como utilizá-los; o objetivo era, pois, desenvolver o raciocínio e o espírito crítico. Segundo, sistema eficiente de busca de jurisprudência for formulado, medida necessária para o uso adequado dos precedentes. Terceiro, as provas constantes dos autos passaram a ser produzidas e preservadas da melhor forma possível" (A influência da American Judicial Review no Brasil, Japão e Alemanha: reflexões e perspectivas sobre o papel atual do Judiciário, p. 553).

${ }^{356}$ VíctOR FERRERES elenca duas ordens de obstáculos a dificultar o caminho de respeito (vinculação) da jurisprudência especificamente na Espanha: institucionais e culturais. Os primeiros estão ligados à dificuldade de um tribunal, como Supremo Tribunal espanhol, de julgar com qualidade, ante ao enorme número de processos entrados anualmente. Como diz o autor, "no puede haber jurisprudencia vinculante si el Supremo no dipone del tiempo necesario para meditar con profundidad acerca de los problemas jurídicos planteados en los recursos, y para perfilar con claridad y sin contradicciones los criterios con arreglo a los cuales deben resolverse". Questões culturais também impedem que se institua um verdadeiro sistema de respeito a precedentes, pois isso pressupõe uma nova maneira de ler e escrever decisões judiciais, que devem ser proferidas tendo em conta, antes de tudo, a regra que estão tratando de assentar. Assim como acontece no Brasil, na Espanha, segundo FERRERES, acaba sendo difícil "extraer de las sentencias del Tribunal Supremo y del Tribunal Constitucional su verdadera ratio decidendi”, não sendo raro que decisões distintas tragam teses contraditórias ou marchem em direções opostas sem que o intérprete possa retirar delas uma regra clara e realmente estável (ob. cit., p. 75-78).

${ }^{357}$ Cf. CRUZ E TUCCI, Precedente judicial como fonte do direito, p. 16. 
se já houve decisão anterior sobre caso semelhante ou idêntico. E mais: que se estruturem por critério de busca vinculado à ratio decidendi, ou seja, ao núcleo do ato decisório.

Essas reformas de perspectiva é que poderão, efetivamente, fazer valer o respeito aos precedentes do STF e do STJ, sem trazer retrocessos ou efeitos colaterais que acabarão neutralizando todo esforço por tornar o sistema jurídico mais coeso, unitário, seguro e isonômico. Essa mudança cultural, nos dizeres de MITIDIERO, está pré-ordenada para a preservação da liberdade e para a realização da igualdade mediante a promoção da segurança jurídica. Sem ela, o Supremo Tribunal Federal e o Superior Tribunal de Justiça permanecerão reféns de um sistema desgastado, e o processo civil continuará sendo "um jogo perversamente escravizado pela aleatoriedade de seus resultados",358.

${ }^{358}$ Ob. cit., p. 129-130. 


\section{CAPÍTULO 5 - CONCLUSÕES}

Vimos que a origem correicional da reclamação constitucional demonstra que sua função de controlar a aplicação (rectius: execução) de decisões judiciais foi idealizada para os casos em que não havia outro instrumento processual disponível. Porém, desde então, sempre se pode traçar um vínculo entre a eficácia das decisões e a funcionalidade da reclamação.

Depois de ter passado a ser utilizada e ter seu procedimento traçado pelo Supremo Tribunal Federal, considerando as peculiaridades da Corte e a eficácia das decisões dela emanadas, o instituto adquiriu a função de controlar não apenas a executividade imanente a toda decisão judicial, mas também a normatividade vinculante de que são dotados certos atos jurisdicionais.

Diferentemente dos países que adotam sistema legítimo de respeito a precedentes, no Brasil, a obrigatoriedade das teses fixadas pelo Poder Judiciário decorre de disposição legal. Assim, enquanto nos países de common law a observância dos precedentes decorre da histórica necessidade de sistematização do Direito, com segurança e certeza, e passou a ser inerente à cultura jurídica e social, entre nós esse respeito dependerá de mecanismos de controle não cogitados naqueles países.

O sistema jurídico brasileiro tem passado por grandes transformações, voltadas a ampliar a eficácia das decisões judiciais. Essas mudanças, mais que se preocuparem com a segurança jurídica, a estabilidade das relações, a certeza e a justiça decorrentes de uma correta organicidade do sistema de produção de normas pelo Poder Judiciário, visam a reduzir o volume de processos que o estágio atual da sociedade, somado à prodigalidade da Constituição Federal, tem levado aos tribunais do País. Ao lado da ampliação da eficácia dos precedentes, caminha a necessidade de coletivização das demandas semelhantes, ou seja, a previsão de mecanismos voltados à economia e à eficiência do Poder Judiciário.

As nossas súmulas, além de, em regra, não serem criadas a partir de casos semelhantes do ponto de vista dos fatos, são aplicadas sem a devida atenção às circunstâncias fáticas dos precedentes que as originaram, ainda que tais elementos estejam disponíveis nos sítios eletrônicos dos tribunais. A forma como são construídas e aplicadas as súmulas, na prática, torna difícil encontrar diferença entre elas e o direito legislado. Sob 
essa óptica, controlar a aplicação das teses esculpidas nessas súmulas, portanto, não difere de controlar a aplicação da lei.

A criação de um instrumento de controle de aplicação de precedentes do Supremo Tribunal Federal e do Superior Tribunal de Justiça pode representar um atalho para a jurisdição desses tribunais, injustificado do ponto de vista da isonomia. O equívoco de quem entende viável fazer o controle nesses moldes está na confusão entre força normativa e força executiva das decisões judiciais e na pretensão de controlar sua observância por meio de uma única e indistinta técnica processual.

A reclamação se desenvolveu historicamente para controlar não a força normativa das decisões judiciais, mas a sua eficácia executiva, ou seja, a potencialidade de gerar efeitos concretos no mundo dos fatos. O controle dessa eficácia pode e deve ser objeto de controle judicial pelo órgão responsável pela execução do julgado.

Por outro lado, a utilização da reclamação como mecanismo de controle da eficácia vinculante das teses jurídicas emanadas do STF e do STJ implicará aceitar a legitimidade ativa de todos os destinatários da norma geral oriunda do precedente vinculante e contrariar o próprio fundamento da instituição de um sistema de respeito a precedentes. Essa abertura de legitimidade andará na contramão das reformas, pois implicará uma reatomização dos litígios de proporções incalculáveis.

Por esse motivo, afirmamos que o controle de aplicação da regra oriunda da eficácia normativa dos precedentes, dado possuir caráter erga omnes, não deve ser objeto de controle direto pelo órgão que produziu o precedente, especialmente se se tratar, como se trata no Brasil, de órgãos de cúpula do Poder Judiciário.

Destarte, o controle do respeito à eficácia normativa geral dos precedentes vinculantes deve ser feito nos mesmos moldes do controle da eficácia geral dos atos normativos editados pelos demais poderes, de acordo com as regras ordinárias de competência.

Em decorrência disso, os artigos 102, I, $f$, e 105, I, $l$, devem ser interpretados no sentido de estabelecer, para a reclamação neles prevista, uma legitimidade ativa restrita e equivalente à das causas nas quais se produziram os precedentes. 
Pelas mesmas razões, recomenda-se a revogação da previsão constitucional de cabimento de reclamação para salvaguarda de súmula vinculante, prevendo-se hipótese nova de recurso extraordinário para os casos em que o ato violador possua natureza judicial; tratando-se de ato não judicial, o controle de aplicação da norma emanada do verbete vinculante também deve ser feito nas instâncias e pelos instrumentos ordinários de controle da legalidade dos atos administrativos.

Também pelos mesmos motivos, a generalização do uso da reclamação direta aos órgãos de cúpula do Judiciário como meio de controlar a observância de todos os precedentes vinculantes, prevista no novo Código de Processo Civil, significará um aumento descomunal de processos, dada a circunstância de que o sistema continuará exigindo, como condição da ação reclamatória, que a decisão reclamada não tenha transitado em julgado, ou seja, que o interessado, além de reclamar, recorra.

Procurou-se demonstrar no presente estudo que a reclamação ajuizada diretamente no STF e no STJ, como meio de controle da normatividade vinculante de suas decisões, além de não garantir, efetiva e necessariamente, a instituição de um verdadeiro sistema de respeito a precedentes no País, não se coaduna com as condições ainda precárias da máquina judiciária brasileira. 


\section{BIBLIOGRAFIA}

ABBOUD, Georges. Precedente judicial versus jurisprudência dotada de efeito vinculante.In:WAMBIER, Teresa Arruda Alvim (coord.). Direito jurisprudencial. São Paulo: RT, 2012.p. 491-552.

ARAÚJo CINTRA, Antonio Carlos de. Comentários ao Código de Processo Civil.3.ed. Rio de Janeiro: Forense, 2008. v. IV.

ARRUDA ALVIM NETTO, José Manuel de. Correição parcial.Revista dos Tribunais, v.452, p. 11, jun. 1973.

ASSIS, Araken de. Manual dos recursos. 6. ed.São Paulo: RT, 2014.

ATAIIDE JÚNIOR, Jaldemiro Rodrigues. Precedentes vinculantes e irretroatividade do direito no sistema processual brasileiro - os precedentes dos tribunais superiores e sua eficácia temporal.Curitiba: Juruá, 2012.

BARBI, Celso Agrícola. Do mandado de segurança. 3. ed. Rio de Janeiro: Forense, 1976.

BARBOSA MOREIRA, José Carlos.A Emenda Constitucional n. 45 e o processo. In: Temas de Direito Processual, nona série, p. 21-37. São Paulo: Saraiva, 2007.

Comentários ao Código de Processo Civil. 14. ed. Rio de Janeiro: Forense, 2008.v. V.

Súmula, jurisprudência, precedente: uma escalada e seus riscos. In: Temas de Direito Processual, nona série, p. 299-313. São Paulo: Saraiva, 2007.

BARROSO, Luis Roberto. $O$ controle de constitucionalidade no direito brasileiro, 2. ed. São Paulo: Saraiva, 2006.

BEDAQUE, José Roberto dos Santos. Garantia da amplitude da produção probatória.In:BOTELHO DE MESQUITA, José Ignácio. A súmula da jurisprudência predominante no Supremo Tribunal Federal. In: Teses, estudos e pareceres de processo civil.São Paulo: RT, 2005.v. 2, p. 215-226.

. O desmantelamento do sistema brasileiro de controle de constitucionalidade. In:

Teses, estudos e pareceres de processo civil.São Paulo: RT, 2005.v. 2, p. 258.

BULLIER, Antoine J.LaCommon law. Paris: Dalloz, 2002.

BUSTAMANTE, Thomas da Rosa de. Teoria do precedente judicial: a justificação e a aplicação de regras jurisprudenciais. São Paulo: Noeses, 2012. 
BUZAID, Alfredo. Da uniformização de jurisprudência. Boletim da Faculdade de Direito da Universidade de Coimbra, v. LVIII, Estudos em homenagem aos Profs. Doutores M. Paulo Merêa e G. Braga da Cruz. Coimbra: 1982, p. 127-167. A crise do Supremo Tribunal Federal. Estudos de direito. São Paulo: Saraiva, 1972.

CAETANO, Marcelo. História do direito português. Lisboa/São Paulo: Verbo, s.d.v. I. CAMBI, Eduardo.Súmulas vinculantes. Revista de Processo, v. 168, p. 143, fev. 2009.

CAMBI, Eduardo; MINGATI, Vinícius Secafen. Nova hipótese de cabimento da reclamação, protagonismo judiciário e segurança jurídica. Revista de Processo, v. 196, p. 296, jun. 2011.

CAMBI, Eduardo; NEVES, Aline Regina das. Repercussão geral e PEC 209/2012. Revista de Processo, v. 220, p. 183, jun. 2013.

CAPPELLETTI, Mauro. Juizes irresponsáveis? Trad. Carlos Alberto Alvaro de Oliveira. Porto Alegre: Sergio Antonio Fabris, 1989.

. Juizes legisladores? Trad. Carlos Alberto Alvaro de Oliveira. Porto Alegre: Sergio Antonio Fabris, 1993.

O controle judicial de constitucionalidade das leis no direito comparado.2. ed.

Trad. Aroldo Plínio Gonçalves. Porto Alegre: Sergio Antonio Fabris, 1992.

CAPPELLETTI, Mauro; GARTH, Bryan. Acesso à justiça. Trad. Ellen Gracie Northfleet. Porto Alegre: Sergio Antonio Fabris, 1988.

CARNEIRO JÚNIOR, Amílcar Araújo. A contribuição dos precedentes judiciais para a efetividade dos direitos fundamentais. Brasília: Gazeta Jurídica, 2012.

CARREIRA, Guilherme Sarri. Algumas questões a respeito da súmula vinculante e precedente judicial.Revista de Processo, v. 199, p. 213, set. 2011.

CARVALHO, Ivan Lira de. Decisões vinculantes. Revista dos Tribunais, v. 745, p. 48, nov. 1997.

CASTANHEIRA NEVES, A.O instituto dos 'assentos' e a função jurídica dos Supremos Tribunais. Coimbra: Coimbra Ed., 1983.

CORDOPATRI, Francesco. La ratio decidendi (considerazioniattuali). Rivista di Diritto Processuale, v. 45, p. 148, 1990.

La ratio decidendi (profilo storico e comparativo). Rivista di Diritto Processuale, v. 44, p. 701, 1989. 
CORTEZ, Cláudia Helena Poggio. O cabimento de reclamação constitucional no âmbito dos juizados especiais estaduais. Revista de Processo, v. 188, p. 253, out. 2010.

COSTA, Eduardo José da Fonseca; NOGUEIRA, Pedro Henrique Pedrosa(org.). Reclamação constitucional. Salvador: JusPodium, 2013.

COUTURE, Eduardo J. Interpretação das leis processuais, 4. ed. Trad. Gilda Maciel Corrêa Meyer Russomano. Rio de Janeiro: Forense, 2001.

CRUZ, Luana Pedrosa de Figueiredo. Reclamação constitucional para garantia de autoridade de decisão do STJ e a violação dos deveres das partes. In: MEDINA, José Miguel Garciaet al.(org.). Os poderes do juiz e o controle das decisões judiciais: estudos em homenagem à Professora Teresa Arruda Alvim Wambier. São Paulo: RT, 2008.

CRUZ E TUCCI, José Rogério (org.). Direito processual civil americano contemporâneo. São Paulo: Lex, 2010.

(coord.).Garantias constitucionais do processo civil. São Paulo: RT, 1999.p. 151-189.

Precedente judicial como fonte do direito. São Paulo: RT, 2004.

CRUZ E TUCCI, José Rogério; AZEVEDO, Luiz Carlos. Lições de história do processo civil lusitano. São Paulo: RT/Coimbra Ed., 2009.

CUNHA, Antônio Geraldo da. Dicionário etimológico da língua portuguesa.3. ed. Rio de Janeiro: Lexikon, 2007.

CUNHA, Leonardo José Carneiro da.Natureza jurídica da reclamação constitucional. In:NERY JUNIOR, Nelson; WAMBIER, Teresa Arruda Alvim.Aspectos polêmicos e atuais dos recursos cíveis e de outros meios de impugnação das decisões judiciais. São Paulo: RT, 2005. v. 8, p. 325-341.

Recursos repetitivos. In: MENDES, Aluisio Gonçalves de Castro; WAMBIER, Teresa Arruda Alvim (org.),O processo em perspectiva: Jornadas Brasileiras de Direito Processual. São Paulo: RT, 2013. p. 247-257.

DANTAS, Marcelo Navarro Ribeiro. Novidades em reclamação constitucional: seu uso para impor o cumprimento de súmula vinculante. In: MEDINA, José Miguel Garcia et al. (org.). Os poderes do juiz e o controle das decisões judiciais: estudos em homenagem à professora Teresa Arruda Alvim Wambier. São Paulo: RT, 2008.

Reclamação constitucional no direito brasileiro. Porto Alegre: Sergio Antonio Fabris, 2000. 
DI PIETRO, Maria Sylvia Zanella. Direito administrativo. 12. ed. São Paulo: Atlas, 2000. DIDIER JR., Fredie. A teoria dos princípios e o projeto do novo CPC. In:DIDIER JR., Fredie;MOUTA, José Henrique; KLIPPEL, Rodrigo (coord.). O projeto do novo Código de Processo Civil:estudos em homenagem ao Professor José de Albuquerque Rocha. Salvador: JusPodium, 2011.

DIDIER JR., Fredie;BRAGA, Paula Sarno; OLIVEIRA, Rafael Alexandria de. Curso de direito processual civil.8. ed.Salvador: JusPodium, 2013.v. 2.

DINAMARCO, Cândido Rangel. A reclamação no processo civil brasileiro. Nova era do processo civil. 3. ed. São Paulo: Malheiros, 2009.p. 203-215.

A reforma do Poder Judiciário. Nova era do processo civil.3. ed. São Paulo: Malheiros, 2009.p. 197-212.

. Decisões vinculantes. Revista de Processo, v. 100, p. 166, out. 2000.

. Instituições de direito processual civil. 3. ed. São Paulo: Malheiros, 2009. v.

IV.

. Instituições de direito processual civil. 6. ed. São Paulo: Malheiros, 2009.v. I a

III.

- Momento de eficácia da sentença constitutiva. In: Fundamentos do processo civil moderno. 6. ed. São Paulo: Malheiros, 2010.tomo I,p. 949-972.

O conceito de mérito em processo civil. Fundamentos do processo civil moderno. 6. ed. São Paulo: Malheiros, 2010.tomo I,p. 299-348.

Súmulas vinculantes. Fundamentos do processo civil moderno. 6. ed. São Paulo: Malheiros, 2010.tomo I,p. 213-244.

DINIZ, Maria Helena. As lacunas no direito.7. ed. São Paulo: Saraiva, 2002.

DUTRA, Carlos Roberto de Alckmin. Controle abstrato de constitucionalidade: análise dos princípios processuais aplicáveis. São Paulo: Saraiva, 2012.

FARNSWORTH, E. Allan. Introdução ao sistema jurídico dos Estados Unidos. Trad. Antonio Carlos Diniz de Andrada. Rio de Janeiro: Forense, s.d.

FERRARI, Regina Maria Macedo Nery. Efeitos da declaração de inconstitucionalidade.5. ed. São Paulo: RT, 2004.

FERRERES, Vítor; XIOL, Juan Antonio. El carácter vinculante de la jurisprudencia. Madrid: Fundación Coloquio Jurídico Europeo, 2009. 
FINE, Toni M.Introdução ao sistema jurídico anglo-americano. Trad. Eduardo Saldanha. São Paulo: Martins Fontes, 2011.

FONSECA, João Francisco Naves da. Exame dos fatos nos recursos extraordinário e especial. São Paulo: Saraiva, 2012.

GARCIA, Dínio de Santis. Efeito vinculante dos julgados da Corte Suprema e dos Tribunais Superiores. Revista dos Tribunais, v. 734, p. 40, dez. 1996.

GOES, Gisele Santos Fernandes. Reclamação constitucional. In:DIDIER JR., Fredie (org.).Ações constitucionais. Salvador: JusPodium, 2006.p. 501-522.

GRAU, Eros Roberto. Por que tenho medo dos juízes(a interpretação/aplicação do direito e os princípios).6. ed. São Paulo: Malheiros, 2014.

GRINOVER, Ada Pellegrini. A reclamação para garantia da autoridade das decisões dos tribunais. In: O processo:estudos e pareceres.2. ed. São Paulo: DPJ, 2005.p. 123-131.

Paixão e morte do contempt of court brasileiro (art. 14 do Código de Processo

Civil). In: O processo: estudos e pareceres. 2. ed.São Paulo: DPJ, 2005. p. 211-219.

ITURRALDE SESMA, Victoria. Precedente judicial. Eunomia - Revista em Cultura de la Legalidad, n. 4, p. 194-201, mar.-ago. 2013.

Razonamiento judicial a partir de precedentes. In: GARCIA, Ramón Ortega (coord.). Teoría del derecho y argumentación jurídica: ensayos contemporáneos. Valencia: Tirantlo Blanch, 2013.

JANSEN, Rodrigo. A súmula vinculante como norma jurídica. Revista de Direito Administrativo, n. 240, p. 225-264, abr.-jun. 2005.

JORGE, Flávio Cheim. Teoria geral dos recusos cíveis.3. ed. São Paulo: RT, 2007.

KOZIKOSKI, Sandro Marcelo. As súmulas vinculantes na esteira da Lei 11.417/2006.In: MEDINA, José Miguel Gargia et al. (coord.).Os poderes do juiz e o controle das decisões judiciais:estudos em homenagem à professora Teresa Arruda Alvim Wambier, p. 1195/1211. São Paulo: RT, 2008.

LAMY, Eduardo Avelar. Súmula vinculante: um desafio. Revista de Processo, v. 120, p. 112, fev. 2005.

LEAL, Roger Stiefelmann. O efeito vinculante na jurisdição constitucional. São Paulo: Saraiva, 2006.

LEONEL, Ricardo de Barros. Reclamação constitucional. São Paulo: RT, 2011. Tutela jurisdicional diferenciada. São Paulo: RT, 2010. 
LIMA, Tiago Asfor Rocha. Precedentes judiciais civis no Brasil. São Paulo: Saraiva,2013. LIMONGI FRANÇA,R. Hermenêutica jurídica. 5. ed. São Paulo: Saraiva, 1997.

LOPES, José Reinaldo de Lima. Uma introdução à história social e política do processo. In: WOLKMER, Antonio Carlos (org.). Fundamentos de história do direito.6. ed. Belo Horizonte: Del Rey, 2011.

LUCON, Paulo Henrique dos Santos. Evolução da Reclamação Constitucional e seu emprego para assegurar a autoridade dos precedentes. In:CRUZ E TUCCI, José Rogério;RODRIGUES, Walter Piva;AMADEO, Rodolfo da Costa Manso Real. Processo civil: homenagem a José Ignácio Botelho de Mesquita. São Paulo: Quartier Latin, 2013.

MACHADO, Marcelo Pacheco. Decisão judicial inconstitucional: e daí?Revista de Processo,v. 216, p. 209, fev. 2013.

MACIEL, Adhemar Ferreira. Poderes reservados versus poderes implícitos.In: BERALDO, Leonardo de Faria;COSTA, Mônica Aragão M. Ferreira e;DOLGA, Lakowsky;MACIEL, Adhemar Ferreira(coord.). Estudos de direito constitucional:homenagem ao Professor Ricardo Arnaldo Malheiros Fiuza. Belo Horizonte: Del Rey, 2009.p. 1-7.

MAGALHÃES, Breno Baía. Considerações acerca da natureza jurídica da reclamação constitucional.Revista de Processo, v. 210, p. 399, ago. 2012.

MAIA, Izabelle Albuquerque Costa. Violação à súmula vinculante e cabimento de ação rescisória.In:FUX, Luiz; NERY JR., Nelson; WAMBIER, Teresa Arruda Alvim (coord.). Processo e Constituição:estudos em homenagem ao professor José Carlos Barbosa Moreira. São Paulo: RT, 2006.p.237-244.

MANCUSO, Rodolfo de Camargo. Divergência jurisprudencial e súmula vinculante.4. ed. São Paulo: RT, 2010. Jurisdição coletiva e coisa julgada. 3. ed. São Paulo: RT, 2012.

MARINONI, Luiz Guilherme.A ética dos precedentes. São Paulo: RT, 2014. .Eficácia vinculante: a ênfase à ratiodecidendi e à força obrigatória dos precedentes. Revista de Processo, v. 184, p. 9, jun. 2010. O STJ enquanto corte de precedentes. São Paulo: RT, 2013. Precedentes obrigatórios.2. ed. São Paulo: RT, 2011.

MAXIMILIANO, Carlos. Hermenêutica e aplicação do direito. 19. ed.Rio de Janeiro: Forense, 2004. 
MEDEIROS, Maria Lúcia. Anotações sobre a correição parcial. Revista de Processo,v. 68, p. 116-135, out.-dez. 1992.

MEDINA, José Miguel Garcia. Processo de execução e cumprimento de sentença,.4. ed. São Paulo: RT, 2014.

MEIRELLES, Hely Lopes; MENDES, Gilmar Ferreira; WALD, Arnoldo. Mandado de segurança e ações constitucionais. 36. ed. São Paulo: Malheiros, 2014.

MENDES, Aluísio Gonçalves de Castro. Resolução coletiva de conflitos. In: MENDES, Aluisio Gonçalves de Castro; WAMBIER, Teresa Arruda Alvim (org.). O processo em perspectiva: Jornadas Brasileiras de Direito Processual. São Paulo: RT, 2013.p. 47-70.

MENDES, Gilmar Ferreira. Controle abstrato de constitucionalidade: ADI, ADC e ADO. Comentários à Lei n. 9.868/99. São Paulo: Saraiva, 2012. Jurisdição constitucional.5. ed. São Paulo: Saraiva, 2009.

MENDONÇA, Rodrigo Gomes de. Teoria da transcendência dos motivos determinantes das decisões do Supremo Tribunal Federal em controle difuso de constitucionalidade: os limites da coisa julgada e o enunciado de súmula vinculante. Revista de Processo, v. 199, p. 307 , set. 2011.

MINGATI, Vinícius Secafen. Reclamação (neo)constitucional: precedentes, segurança jurídica e os juizados especiais. Brasília: Gazeta Jurídica, 2013.

MITIDIERO, Daniel. Cortes Superiores e Cortes Supremas:do controle à interpretação, da jurisprudência ao precedente. São Paulo: RT, 2013.

MONIZ DE ARAGÃO, Egas Dirceu. A correição parcial. São Paulo: José Bushatsky, 1969.

MORATO, Leonardo L. Reclamação e sua aplicação para o respeito da súmula vinculante. São Paulo: RT, 2007.

MORETO, Mariana Capela Lombardi. O precedente judicial no sistema processual brasileiro. Tese de Doutorado. São Paulo: Faculdade de Direito da Universidade de São Paulo, 2012.

MONTESQUIEU, Charles de Secondat, Baron de. O espírito das leis.2. ed. Trad. Roberto Leal Ferreira. São Paulo: Martins Fontes, 2000.

NEGRÃO, Theotonioet al.Código de Processo Civil e legislação processual em vigor.45. ed. São Paulo: Saraiva, 2013. 
NEVES, Daniel Amorim Assumpção. Ações constitucionais. São Paulo: GEN/Método, 2011.

NERY JUNIOR, Nelson. Teoria geral dos recursos. 7. ed. São Paulo: RT, 2014.

ONODERA, Marcus Vinicius Kiyoshi. A Influência da American Judicial Review no Brasil, Japão e Alemanha: reflexões e perspectivas sobre o papel atual do Judiciário. In: MACIEL, Adhemar Ferreira et. al.(coord.). Estudos de direito constitucional:homenagem ao professor Ricardo Arnaldo Malheiros Fiuza.Belo Horizonte: Del Rey, 2009.p. 547.

OTEIZA, Eduardo. El problema de launiformidad de lajurisprudencia en América Latina. Revista de Processo, v. 136, p.151, jun. 2006.

PACHECO, José da Silva. A "reclamação" no STF e no STJ de acordo com a nova Constituição.Revista dos Tribunais, v. 646, p. 19.

PARENTE, Eduardo de Albuquerque. Jurisprudência: da divergência à uniformização. São Paulo: Atlas, 2006.

PEREIRA, José Horácio Cintra Gonçalves. Da reclamação (breves considerações). In:CARVALHO, Milton Paulo de; CASTRO, Daniel Penteado de (org.). Direito processual civil.São Paulo: QuartierLatin, 2011.v. 2.

PIGNATARI, Alessandra Aparecida Calvoso Gomes. Efeitos processuais no controle judicial de constitucionalidade. Brasília: Gazeta Jurídica, 2014.

PINTO, Teresa de Arruda Alvim. Mandado de segurança contra ato judicial. São Paulo: RT, 1989.

PIZZOL, Patricia Miranda. A competência no processo civil. São Paulo: RT, 2003.

PORTO, Sérgio Gilberto. Coisa julgada civil.4. ed. São Paulo: RT, 2011.

RAMIRES, Maurício. Crítica à aplicação dos precedentes no direito brasileiro. Porto Alegre: Livraria do Advogado, 2010.

RAMOS, Elival da Silva. Controle de constitucionalidade no Brasil: perspectivas de evolução. São Paulo: Saraiva, 2010.

RAMOS, Glauco Gumerato. Reclamação no Superior Tribunal de Justiça. Revista de Processo, v. 192, p. 369, fev. 2011.

REALE, Miguel. Lições preliminares de direito. 21. ed. São Paulo: Saraiva, 1994.

RODOVALHO DOS SANTOS, Thiago. Do respeito às decisões do STF e a súmula vinculante. Revista de Direito Brasileira, ano 2, v. 2, p. 229, jan.-jun. 2012. 
ROSSI, Júlio César. O precedente à brasileira: súmula vinculante e o incidente de resolução de demandas repetitivas. Revista de Processo, v. 208, p. 203, jun. 2012.

RUA, Julio Cueto. El “common law”. Buenos Aires: La Ley, 1957.

SALLES, José Carlos de Moraes. Súmula vinculante: solução ou retrocesso? Revista dos Tribunais, v. 864, p. 11, out. 2007.

SARLET, Ingo Wolfgang; MARINONI, Luiz Guilherme; MITIDIERO, Daniel. Curso de direito constitucional. São Paulo: RT, 2012.SCARPINELLA BUENO, Cassio. Curso sistematizado de direito processual civil.2. ed. São Paulo: Saraiva, 2010.v. 5.

. Curso sistematizado de direito processual civil. São Paulo: Saraiva, 2010. v. 2,

t. III.

.Direito, interpretação e norma jurídica: uma aproximação musical do direito. Revista de Processo, v. 111, p. 223, jun.-set. 2003.

. Projetos de novo Código de Processo Civil comparados e anotados. São Paulo: Saraiva, 2013.

SCARTEZZINI, Ana Maria Goffi Flaquer. A súmula vinculante - o contraditório e a ampla defesa. Revista de Processo, v. 120, p. 68, fev. 2005.

SICA, Heitor Vitor Mendonça. Preclusão processual civil.2. ed. São Paulo: Atlas, 2008. Reflexões em torno da teoria geral dos procedimentos especiais.Revista de Processo, 208, p. 61, jun. 2012.

SILVA, Evandro Lins e. A questão do efeito vinculante. Revista Brasileira de Ciências Criminais, v. 13, p. 110, jan. 1996.

O salão dos passos perdidos. Rio de Janeiro: Nova Fronteira, 1997.

SOARES, Guido Fernando Silva. Common law: introdução ao direito dos EUA.2. ed. São Paulo: RT, 2000.

STRECK, Lenio. Hermenêutica jurídica $e(m)$ crise: uma exploração hermenêutica da construção do direito. 10. ed. Porto Alegre: Livraria do Advogado, 2011.

Súmulas vinculantes em terraebrasilis: necessitamos de uma "teoria para a elaboração de precedentes"? Revista Brasileira de CiênciasCriminais, v. 78, p. 284, maio 2009.

TALAMINI, Eduardo. Objetivação do controle incidental de constitucionalidade e força vinculante (ou "devagar com o andor que o santo é de barro"). In:NERY JUNIOR, 
Nelson;WAMBIER, Teresa Arruda Alvim. Aspectos polêmicos e atuais dos recursos cíveis e assuntos afins.São Paulo: RT, 2011.v. 12.

TARANTO, Caio Márcio Gutterres. Precedente judicial: autoridade e aplicação na jurisdição constitucional.Rio de Janeiro: Forense/GEN, 2010.

TARUFFO, Michele. Idee per una teoria della decisione giusta.Sui confini:scritti sulla giustizia civile. Bologna: Il Mulino, 2002.p. 219.

.Il diritto alla prova nel processo civile. Rivista di Diritto Processuale, n.1, p. 74120, jan.-mar. 1984.

Il giudice e la rule of law. Sui confini:scritti sulla giustizia civile.Bologna: Il Mulino, 2002.p. 177.

- Il processo civiledicivil law e dicommon law: aspettifondamentali. Sui confini:scritti sulla giustizia civile. Bologna: Il Mulino, 2002. p. 67.

Legalità e giustificazione della creazione giudiziaria del diritto. Sui confini: scrittisullagiustiziacivile. Bologna: Il Mulino, 2002.p. 195.

Precedente e giurisprudenza. Napoli: Editoriale Scientifica, 2007.

TAVARES, André Ramos. Paradigmas do judicialismo constitucional. São Paulo: Saraiva, 2012.

TEIXEIRA, Sálvio de Figueiredo. As tendências brasileiras rumo à jurisprudência vinculante. Revista do Instituto dos Advogados de São Paulo, v. 2, p. 145, jul. 1998.

TELLES JÚNIOR, Goffredo da Silva. A criação do direito. 2. ed. São Paulo: Ed. Juarez de Oliveira, 2004.

TIMM, Luciano Benetti; JOBIM, Eduardo. Súmula vinculante à luz do direito inglês: quebrando mitos e lançando luzes sobre um novo paradigma na redação e na estruturação das súmulas doSTF. In:MARTINS, Ives Gandra da Silva; JOBIM, Eduardo (coord.).O processo na Constituição. São Paulo: Quartier Latin, 2008.p. 914-926.

TOSTA, Jorge (coord.). Juizados Especiais da Fazenda Pública. São Paulo: Campus Jurídico, 2012.

WAMBIER, Teresa Arruda Alvim (coord.). Direito jurisprudencial. São Paulo: RT, 2012. Em direção ao common law? In: MENDES, Aluisio Gonçalves de Castro; WAMBIER, Teresa Arruda Alvim (org.). O processo em perspectiva: Jornadas Brasileiras de Direito Processual.São Paulo: RT, 2013.p. 371-378. 
Súmula vinculante: desastre ou solução? Revista de Processo, v. 98, p. 295, abr. 2000.

WATANABE, Kazuo. Da cognição no processo civil.2. ed. Campinas: Bookseller, 2000.

WOLKART,Erik Navarro. Precedente judicial no processo civil brasileiro:mecanismos de objetivação do processo. Salvador: JusPodium, 2013.

ZANETI JR., Hermes. O valor vinculante dos precedentes. Salvador: JusPodium, 2015.

ZAVASCKI, Teori Albino. Eficácia das sentenças na jurisdição constitucional.2. ed. São Paulo: RT, 2012.

Processo coletivo:tutela de direitos coletivos e tutela coletiva de direitos.5. ed.

São Paulo: RT, 2011. 
Autorizo a reprodução e divulgação total ou parcial deste trabalho, por qualquer meio convencional ou eletrônico, para fins de estudo e pesquisa, desde que citada a fonte.

Serviço de Biblioteca e Documentação

Faculdade de Direito da Universidade de São Paulo

Jacob, Cesar Augusto Alckmin

O52g A reclamação como instrumento de controle da aplicação de precedentes do STF e do STJ: análise funcional, estrutural e crítica /Cesar Augusto Alckmin Jacob. -- São Paulo:

USP / Faculdade de Direito, 2015.

$173 \mathrm{f}$.

Orientador: Prof. Dr. Heitor Vitor Mendonça Sica

Dissertação (Mestrado), Universidade de São Paulo, USP, Programa de Pós-Graduação em Direito, Direito Processual Civil, 2015.

1. Reclamação. 2. Precedentes judiciais. 3. Ações (Processo civil). 4. Recursos (Processo Civil). 5. Poder judiciário.

I. Sica, Heitor Vitor Mendonça. II. Título.

CDU 


\section{RESUMO}

JACOB, Cesar Augusto Alckmin. A reclamação como instrumento de controle da aplicação de precedentes do STF e do STJ: análise funcional, estrutural e crítica. 2015, 173 f. Tese (Mestrado) - São Paulo, Faculdade de Direito da Universidade de São Paulo.

O trabalho estuda a reclamação como instrumento de controle de precedentes do Supremo Tribunal Federal e do Superior Tribunal de Justiça. O estudo se inicia com a análise do desenvolvimento do instituto desde sua origem correicional, passando por sua constitucionalização até sua previsão no novo Código de Processo Civil, que generaliza seu cabimento como meio de controle da eficácia vinculante dos precedentes. Em seguida, passamos à análise do sistema brasileiro de respeito aos precedentes, fazendo uma breve comparação com países do common law, e concluímos que, no Brasil, o efeito vinculante, assim entendida a força que torna obrigatória a observância da norma extraível das decisões judiciais, só existe se houver previsão expressa na Constituição ou na lei. Também constatamos que o sistema adotou a reclamação a ser ajuizada diretamente perante o STF e o STJ como instrumento processual de controle da observância dessa força vinculante. Verificamos que, além de valorizar a segurança jurídica, a isonomia e a justiça das decisões, a adoção de um sistema de respeito a precedentes no Brasil tem como confessado objetivo a otimização do serviço judiciário e a redução dos processos pendentes nos tribunais superiores. Todavia, a utilização da reclamação como meio de controle da eficácia vinculante dos precedentes vai de encontro àqueles objetivos, pois reatomiza os litígios sem que isso signifique maior respeito à obrigatoriedade dos precedentes. 


\begin{abstract}
JACOB, Cesar Augusto Alckmin. La "relação" come strumento per controllare l'applicazione dei precedenti di STF e STJ: analisi funzionale, strutturale e critica. 2015, 173 f. Tesi (Master) -São Paulo, Facoltà di Giurisprudenza, Università di São Paulo.

Questo documento studia la "reclamação" come strumento di controllo dei precedenti dello "Supremo Tribunal Federal" e dello"Superior Tribunal de Justiça”. Lo studio inizia con l'analisi dello sviluppo dell'istituto fin dalla sua origine, attraverso la sua costituzionalizzazione alla sua previsione nel progettodi nuovo Codice di Procedura Civile, che generalizza la sua idoneità come un mezzo per controllare l'efficacia vincolante di quanto sopra esposto.Poi ci spostiamo l'analisi del sistema brasiliano per quanto sopra, con un breve confronto con i paesi di common law, e ha concluso che, in Brasile, l'effetto vincolante, che essendo una forza che impone il rispetto di standard di estrazione delle decisioni giudiziarie esiste solo se è previsto espressamente dalla Costituzione o dalla legge. Ho anche scoperto che il sistema adottato la"reclamação" per essere presentata dinanzi ai Alte Corti come un strumentoprocessuale dicontrollo di conformità a tale forza vincolante.Abbiamo scoperto che, oltre a valorizzare la sicurezza giuridica, l'uguaglianza e la giustizia delle decisioni, l'adozione di un sistema rispetto al precedente in Brasile è confessato lo scopo di ottimizzare il servizio giudiziario e la riduzione delle cause pendenti nei tribunali superiori. Mal'uso del credito come un mezzo per controllare l'efficacia del legame precedente non soddisfare tali obiettivi, perché le controversie reatomiza senza volerlo di ingrandimento rispetto al requisito della precedente.
\end{abstract}

